\title{
Language Planning \\ as Nation Building
}

Ideology, policy and implementation in

the Netherlands, $1750-1850$

Gijsbert Rutten

John Benjamins Publishing Company 
Language Planning as Nation Building 


\section{Advances in Historical Sociolinguistics (AHS)}

ISSN 2214-1057

Over the last three decades, historical sociolinguistics has developed into a mature and challenging field of study that focuses on language users and language use in the past. The social motivation of linguistic variation and change continues at the forefront of the historical sociolinguistic enquiry, but current research does not stop there. It extends from social and regional variation in language use to its various communicative contexts, registers and genres, and includes issues in language attitudes, policies and ideologies. One of the main stimuli for the field comes from new digitized resources and large text corpora, which enable the study of a much wider social coverage than before. Historical sociolinguists use variationist and dialectological research tools and techniques, perform pragmatic and social network analyses, and adopt innovative approaches from other disciplines. The series publishes monographs and thematic volumes, in English, on different languages and topics that contribute to our understanding of the relations between the individual, language and society in the past.

For an overview of all books published in this series, please see http://benjamins.com/catalog/ahs

\section{Editors}

Marijke J. van der Wal

Leiden University

\section{Editorial Board}

Wendy Ayres-Bennett

University of Cambridge

Martin Durrell

University of Manchester

Agnieszka Kiełkiewicz-Janowiak

Adam Mickiewicz University, Poznań

William A. Kretzschmar Jr.

University of Georgia, Athens GA

Mieko Ogura

Tsurumi University, Yokohama

Suzanne Romaine

University of Oxford

Daniel Schreier

University of Zurich

\section{Volume 9}

Language Planning as Nation Building

Ideology, policy and implementation in the Netherlands, 1750-1850

by Gijsbert Rutten

\section{Terttu Nevalainen}

University of Helsinki

\author{
Merja Stenroos \\ University of Stavanger \\ Sali A. Tagliamonte \\ University of Toronto \\ Ingrid Tieken-Boon van Ostade \\ Leiden University \\ Donald N. Tuten \\ Emory University, Atlanta GA \\ Wim Vandenbussche \\ Vrije Universiteit Brussel \\ Anna Verschik \\ Tallinn University
}




\section{Language Planning as Nation Building}

Ideology, policy and implementation in the Netherlands, 1750-1850

Gijsbert Rutten

Leiden University Centre for Linguistics

John Benjamins Publishing Company

Amsterdam/Philadelphia 
The paper used in this publication meets the minimum requirements of the American National Standard for Information Sciences - Permanence of Paper for Printed Library Materials, ANSI z39.48-1984.

DOI 10.1075/ahs.9

Cataloging-in-Publication Data available from Library of Congress: LCCN 2018050146 (PRINT) / 2018051486 (E-BOOK)

ISBN 9789027202406 (HB)

ISBN 9789027262769 (Е-ВOOK)

(C) 2019 - John Benjamins B.V.

This e-book is licensed under a Creative Commons CC BY-NC-ND license. To view a copy of this license, visit https://creativecommons.org/licenses/by-nc-nd/4.o/. For any use beyond this license, please contact the publisher.

John Benjamins Publishing Company · https://benjamins.com 


\section{Table of contents}

Preface

CHAPTER 1

Introduction

1.1 Language, nation, nationalism 1

1.2 The schrijftaalregeling 3

1.3 Overview of the book 8

Part I. Setting the stage

CHAPTER 2

Language and nation in Late Modern times

2.1 Introduction $\mathbf{1 3}$

2.2 Political changes 13

2.3 Language and nation 19

2.4 Education 25

2.5 Policy 27

2.6 Final remarks 31

CHAPTER 3

Sociolinguistic space

3.1 Introduction 33

3.2 Diglossia and diaglossia 34

3.3 English and German diaglossia 36

3.4 Dutch diaglossia 40

3.5 Supralocalisation $\quad \mathbf{4 2}$

3.6 Codifications and audiences 44

3.7 Final remarks: From diaglossia to diglossia 48

CHAPTER 4

Metalinguistic space

4.1 Introduction $\mathbf{5 1}$

4.2 The three stages of normative grammar $\quad \mathbf{5 1}$

4.3 From elitist to 'civil' grammar 54

4.4 From 'civil' to national grammar 59

4.5 Nominal inflection as a test case $\mathbf{6 3}$

4.6 Final remarks 71 


\section{Part II. Myth building}

CHAPTER 5

The Golden Age Myth

5.1 Introduction 75

5.2 Language myths and the history of Dutch 77

5.3 The Golden Age Myth 80

5.3.1 Looking back on the Golden Age $\quad \mathbf{8 2}$

5.3.2 Nationalising the Golden Age 86

5.3.3 The Golden Age continues 97

5.4 Final remarks 100

CHAPTER 6

The Myth of Neutrality

6.1 Introduction 103

6.2 Neutrality in Dutch 104

6.3 Two types of neutrality 105

6.4 Neutrality as a shared space 109

6.4.1 From regionality to neutrality as patchwork 110

6.4.2 The mother tongue and hierarchisation $\mathbf{1 1 1}$

6.4.3 Developing neutrality through erasure 113

6.4.4 Polishing the mother tongue $\mathbf{1 1 6}$

6.4.5 Reconceptualising the mother tongue $\mathbf{1 1 7}$

6.5 Neutrality as unmarkedness $\mathbf{1 1 8}$

6.5.1 Educational discourse and policy 119

6.5.2 Enlightenment, emancipation, anonymity - and authenticity $\mathbf{1 2 3}$

6.6 Final remarks $\mathbf{1 2 8}$

Part III. Discipline formation

CHAPTER 7

Nationalising the lexicon

7.1 Introduction $\mathbf{1 3 1}$

7.2 The first plans (1760s-1770s) 133

7.2.1 Van Iperen's proposal 133

7.2.2 Van den Berg's letter 134

7.2.3 The well-reasoned plan $\mathbf{1 3 5}$

7.2.4 The concise plan $\mathbf{1 3 8}$

7.3 The first problems (1770s-1790s) $\quad 139$

7.3.1 The linguistic questions $\mathbf{1 3 9}$

7.3.2 A new plan $\mathbf{1 4 1}$ 
7.4 The first publication (1799) $\quad \mathbf{1 4 3}$

7.5 New plans (1800s-1840s) $\quad \mathbf{1 4 5}$

7.6 The final plan (1849-1852) $\quad \mathbf{1 4 8}$

7.6.1 Congress $1849 \quad \mathbf{1 4 8}$

7.6.2 Congress $1850 \quad 150$

7.6.3 Congress $1851 \quad 154$

7.6.4 Volume I of the WNT (1882) $\mathbf{1 6 2}$

7.7 Final remarks 163

CHAPTER 8

Standard language linguistics

8.1 Introduction 165

8.2 Dutch studies in periodicals $\mathbf{1 6 9}$

8.2.1 The study of Dutch vis-à-vis other cultural fields $\quad 171$

8.2.2 The national language $\mathbf{1 7 2}$

8.2.3 Linguistics 174

8.2.4 The historical model of linguistic and cultural change 175

8.2.5 Conclusions 175

8.3 Matthijs Siegenbeek and the Dutch language $\mathbf{1 7 6}$

8.3.1 Siegenbeek's linguistic heritage $\mathbf{1 8 0}$

8.3.2 The Myth of the Golden Age $\mathbf{1 8 2}$

8.3.3 Dutch in contact with French and German $\quad \mathbf{1 8 4}$

8.3.4 The language of the nation $\quad \mathbf{1 8 7}$

8.3.5 Conclusions $\mathbf{1 8 9}$

8.4 Final remarks $\mathbf{1 8 9}$

CHAPTER 9

The folklorisation of non-standard language

9.1 Introduction 191

9.2 Variation, folklorisation and two types of authenticity 192

9.3 Representing regional variation in the eighteenth century 196

9.3.1 Erasing variation 196

9.3.2 Embracing variation 198

9.3.3 Enregistering variation 201

9.4 The emergence of the study of regional varieties $\quad 206$

9.5 Final remarks $\mathbf{2 1 2}$ 


\section{Part IV. Perspectives from below}

CHAPTER 10

Policy and its implementation in education

With Bob Schoemaker

10.1 Introduction 217

10.2 Educational policy: Major changes 219

10.2.1 Education in the eighteenth century 219

10.2.2 A discourse of change 220

10.2.3 Changes in educational policy $\mathbf{2 2 2}$

10.3 Language norms and language use in the national school system $\quad 225$

10.3.1 The school inspection system $\mathbf{2 2 6}$

10.3.2 Transmission of language norms $\quad 227$

10.3.3 Language use in the classroom $\mathbf{2 3 2}$

10.4 Language norms in teaching materials $\mathbf{2 3 6}$

10.5 Final remarks $\mathbf{2 4 2}$

CHAPTER 11

The effects of planning on usage

With Andreas Krogull

11.1 Introduction 243

11.2 The Going Dutch Corpus 244

11.3 Orthography 250

11.3.1 Vowels 251

11.3.2 Consonants 253

11.4 Morphosyntax 260

11.4.1 The genitive 260

11.4.2 Relativisation 262

11.5 Final remarks 266

CHAPTER 12

Standard language ideology in the Netherlands:

Themes and research directions

Splitting the continuum 270

Authority and authenticity $\mathbf{2 7 2}$

Agency 274

Implementation $\mathbf{2 7 5}$

References

Index 


\section{Preface}

This book is the result of the Going Dutch. The Construction of Dutch in Policy, Practice and Discourse, 1750-1850 research project carried out at the Leiden University Centre for Linguistics (LUCL). This so-called VIDI project was awarded to me by the Netherlands Organisation for Scientific Research (NWO) in 2012. I thank the NWO and the LUCL for granting me the opportunity to develop my ideas in a stimulating academic environment.

I began working on the project in September 2013, and in August 2018 an inspiring and rewarding period of research came to an end. At the end of this long journey, I want to thank my fellow travellers. Marijke van der Wal has long been a conscientious and reliable colleague. It has been a true pleasure to work together again on a big project, and I hope we can continue to do so. Andreas Krogull and Bob Schoemaker have been two perfect $\mathrm{PhD}$ students, whose important contributions to the project are acknowledged in the co-authored chapters.

I also wish to thank David Denison, Martin Durrell, Kristine Horner and Nils Langer, who welcomed Andreas and Bob on their research stays in the UK. Joep Leerssen and Richard Watts have been tremendous in their role as project advisers. Significant contributions to the Going Dutch Corpus have been made by research assistants and master's students, in particular by Christa Bouwmans, Hielke Vriesendorp, Gillan Wijngaards, Brenda Assendelft, Anne Rose Haverkamp and Marlies Reitsma. Tanja Simons has been a great help in alleviating my teaching responsibilities. Thanks are also due to Marilyn Hedges for transforming the language of this book into 'proper' English, to the editors and the anonymous peer reviewers of the Advances in Historical Sociolinguistics series, as well as to the staff at John Benjamins Publishing Company.

Parts of this book have been published before, albeit in different formats and in different contexts, and without the overarching perspective offered here. Earlier versions of the ideas developed here can be found in Rutten (2004, 2009, 2012, 2016a-e, 2018). Chapters 10 and 11 incorporate elements from the PhD dissertations by Andreas Krogull (2018) and Bob Schoemaker (2018) as well as from Schoemaker \& Rutten (2017), Krogull, Rutten \& van der Wal (2017) and Rutten, Krogull \& Schoemaker (accepted).

It is customary to express gratitude to family members, and to paint an optimistic picture of a new period in which more time can be spent together, now that 
the arduous task of writing the book has been fulfilled. Since I have written large parts of this book at home, and new responsibilities are awaiting me in Leiden, a more realistic view is that we will at best spend as much time together as we did before. Thank you so much for your continuing support, Ester. It has been great seeing Izaak and Felix develop from speechless babies into fluent young children, and to not impose Standard Dutch upon them too much.

Finally, I wish to dedicate this book to Geert Dibbets, professor emeritus in the history of linguistics at Radboud University Nijmegen. Geert supervised both my MA thesis (doctoraalscriptie) and my PhD dissertation (proefschrift). While I have since then drifted away from the history of linguistics, and towards the field of historical sociolinguistics, I trust he will recognise his influence on various chapters in this volume, and appreciate the touch of linguistic historiography present in many chapters.

The Hague and Leiden, September 2018 


\section{CHAPTER 1}

\section{Introduction}

\subsection{Language, nation, nationalism}

The intimate relationship of language and nation, and the central role of language in much nationalist discourse need hardly be argued (Joseph 2004: 92-131; Edwards 2009: 205-211). The main project of eighteenth- and nineteenth-century cultural nationalism in Europe was the cultivation of culture (Leerssen 2006: 568). The interest in national cultures fed on a concept of culture that was not limited to a set of shared and highly valued practices and customs. Instead, it viewed culture "as something which represents the very identity of the nation, its specificity amidst other nations" (Leerssen 2006: 568). Arguably the most important aspect of national cultures was language (cf. Leerssen 2006: 569). Thus, the recent Encyclopedia of Romantic Nationalism in Europe (Leerssen 2018) lists nationalistically inspired language planning activities from the eighteenth and nineteenth centuries from all over Europe, from Albanian to Icelandic, and from Portuguese to Lithuanian.

Such language planning activities generally targeted heteroglossia, in Bakhtinian parlance, or diaglossic repertoires found across Early and Late Modern Europe (see Chapter 3). Crowley (1996: 54-98) shows how in eighteenth-century Britain, the desire for monoglossia becomes entangled with nationalism. A particular form of English arises as the idealised variety of the language, which is moreover increasingly conceptualised as the only legitimate form (Watts 2011: 211). In line with the rise of cultural nationalism in eighteenth-century Europe, I interpret the contemporary desire for monoglossia as the rise of modern standard language ideology (Chapter 2).

The rise of standard language ideology in the eighteenth century in countries such as France and England (cf. Lodge 2004: 162; Hickey 2010: 15) came with important changes in metalanguage and language policy. In metalinguistic discourse, the increasing importance of homogeneity was signalled by an increase in strictures and a proliferation of prescriptive language. For example, the existing tradition of English normative grammar led to the new subgenre of the usage guide in the final decades of the eighteenth century (Tieken-Boon van Ostade 2014: 145). In the same period, accent became ideologically significant, and developed into a social marker, first in London, and then across England (Muggestone 2003). In France, later editions of and commentaries on the well-known Remarques sur la langue 
françoise by Vaugelas (1647) are increasingly prescriptive, and certainly more so than the original text (Ayres-Bennett \& Seijido 2011).

From a language policy perspective, efforts at homogenisation, which often combine language planning measures and educational reform, can equally be found across Europe. In Austria, policies developed by Maria Theresia (1740-1780) targeted both the use of German in Austria and the educational system (Havinga 2015). Similarly, nineteenth-century language planning activities by the Real Academia Española, founded in 1713, co-occurred with educational reforms (cf. Villa 2015). Van der Feest Viðarsson (2017) presents a unique collection of nineteenth-century Icelandic student essays that have been corrected for spelling and grammar by their teachers, in line with the contemporary standard language ideology. Likewise, Ziegler (2007) analyses essays written by German grammar schools boys from the nineteenth and the early twentieth century. In a similar vein, Nordlund \& Pallaskallio (2017) discuss the gatekeeping practices of Finnish newspaper editors, who transformed handwritten letters to the editor into nineteenth-century standardised Finnish.

Thus, the rise of nationalism, and of linguistic nationalism in particular, was a pan-European phenomenon, which was often accompanied by linguistic prescriptivism and educational reform. The northern Low Countries, roughly speaking the present-day Netherlands, constitute an exciting historical lab setting for a detailed analysis of this intriguing interplay of language planning and nation-building in eighteenth- and nineteenth-century Europe. In the northern Low Countries, the primarily intellectual interest in the cultivation of culture was almost immediately politicised, giving rise in the first decade of the nineteenth century to a coherent top-down language policy involving status planning, corpus planning and acquisition planning (Wright 2012). With the prominence given to language, Dutch nationalism of the eighteenth and nineteenth centuries resembled other European nationalisms, both well-known examples such as the French and Spanish cases (de Certeau et al. 1975; del Valle 2013) and non-dominant cases such as Catalonia and Schleswig (Hawkey \& Langer 2016). Of course, the link between language and nation in European nationalism from the eighteenth century onwards should not be essentialised. Apart from non-European nationalisms, where language often plays a very different role (e.g. Wright 2016: 78-111), there are also nationalisms in Europe that either do not prioritise language (Hardie 1996; Ichijo 2004: 16; Edwards 2009: 168) or only do so in an atypical way (Watts 1999).

The decades around 1800 constitute the seminal period of European nationalism (Anderson 1983; Smith 1986; Hobsbawm 1990; Kedourie 1993). In recent debates, the old issue of continuity between the Early and Late Modern period has been revived, contesting the constructivist view of nationalism as an essentially 
eighteenth-century phenomenon (Jensen 2016). While it will be difficult to deny the persistence of many social and cultural practices through time, it will be equally difficult to ignore the many crucial discursive transformations of the late eighteenth century, one of which is the rise of nationalism as a political ideology (cf. Brunner, Conze \& Koselleck 1972-1997). Belonging, of course, is not a recent phenomenon, and senses of group identities existed well before, say, 1750. The constructivist view of nationalism does not entail an absence of belonging, group identities and imagined communities before 1750. It merely holds that these were supplemented, and often even overridden, by a discursive, and emphatically political focus on the nation from c. 1750 onwards. Thus, it makes sense to distinguish the old phenomena of national sentiment and national pride from national-ism as "a conscious political programme aimed at the construction of a nation where one didn't exist, or existed only partially" (Bell 2016: 71).

The northern Low Countries around 1800 are characterised by the immediate politicisation and application in policy measures of the newly developed ideology of nationalism. The Dutch language became a symbol of the Dutch nation. For the first time in history, it became subject to official top-down standardisation and to planning efforts aiming at its dissemination across the entire population. Thus, the Dutch case offers an exciting perspective on the concomitant rise of cultural nationalism, national language policies and standard language ideology in this seminal period of nation-building. The crucial historical event was the introduction of the so-called schrijftaalregeling 'written language regulation' in 1804 and 1805.

\subsection{The schrijftaalregeling}

The central focus of this volume is a sociolinguistic event of massive importance that occurred in the northern Low Countries in the early nineteenth century. In 1804 and 1805, the first official spelling and grammar of Dutch were issued. The schrijftaalregeling 'written language regulation' was ordered by the government of the Batavian Republic, as the northern Low Countries were then called (Bakker 1977: 121; Noordegraaf 1985: 256; van Driel 1992: 226-227). It was to be used in the administrative and educational domains. This represents an early case of official top-down language policy, and a classic example of the implementation of a nationalist ideology in a concrete cultural field. The policy involved corpus and status planning, as it promoted the use of the newly designed 'national' language in the domain of administration. In addition, acquisition planning consisted in the envisaged implementation of the national language in the school curriculum through a newly created system of school inspection. 
The language regulations consisted of an officialised orthography and grammar. The orthography was published in 1804 under the title Verhandeling over de Nederduitsche spelling ('Treatise about Dutch spelling'). The author was Matthijs Siegenbeek (1774-1854), professor of Dutch at the university of Leiden. The title page revealed that the spelling book was uitgegeven in naam en op last van het Staats-bewind der Bataafsche Republiek 'published on behalf of and by order of the government of the Batavian Republic' (Siegenbeek 1804a: title page). It was a sizeable book of almost 400 pages, comprising lengthy discussions of prescribed and proscribed variants. To advance the dissemination of the official rules, more concise treatises were published in the following years: in 1805, for example, Siegenbeek himself wrote Kort begrip der verhandeling over de Nederduitsche spelling ('Short overview of the treatise on Dutch orthography'), published ten dienste der scholen 'for the benefit of the schools', as the title page said (Siegenbeek 1805). This work still contained c. 235 pages, of which c. 100 were devoted to an alphabetically ordered word list. Siegenbeek's spelling rules were far from revolutionary: many of his proposals were copied from the works of Adriaan Kluit (1735-1807). Kluit

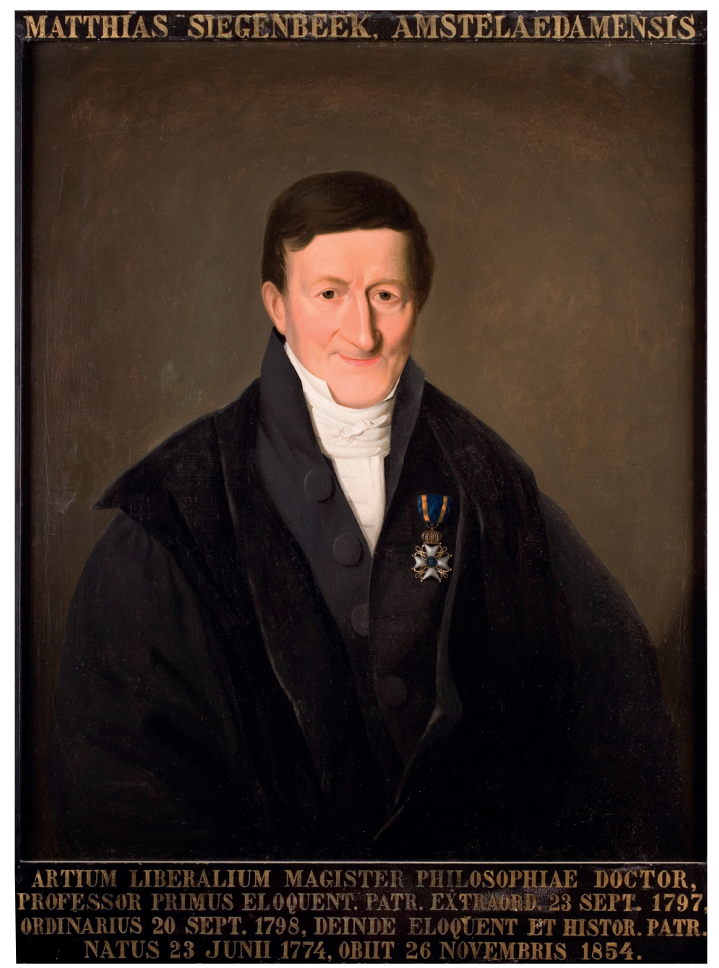

Figure 1. Matthijs Siegenbeek (1774-1854; attributed to Ezechiel Davidson). Collection Leiden University 
was a professor of history at Leiden University, who had published on language in the second half of the eighteenth century (van de Bilt 2009; van Driel \& van der Sijs 2018). Crucial in this context were his essays on the spelling of Dutch of a few decades before (Kluit 1763, 1777). Siegenbeek's spelling rules were only replaced in the 1860s-1880s, when the new spelling proposal by de Vries \& te Winkel (see te Winkel 1863) gradually conquered both the educational and the administrative domain (Hulshof, Kwakernaak \& Wilhelm 2015: 203).

The official grammar, entitled Nederduitsche spraakkunst ('Dutch grammar'), was published in 1805. The author was Pieter Weiland (1754-1841), a minister from the city of Rotterdam, who was simultaneously working on a voluminous dictionary of Dutch, the Nederduitsch taalkundig woordenboek ('Dutch linguistic dictionary', cf. Noordegraaf 2018). The title page of the grammar again explained that the work was uitgegeven in naam en op last van het Staatsbestuur der Bataafsche Republiek 'published on behalf of and by order of the government of the Batavian Republic' (Weiland 1805a: title page). Weiland's grammar contained 328 pages and provided an elaborate overview of the grammar of Dutch, with a strong

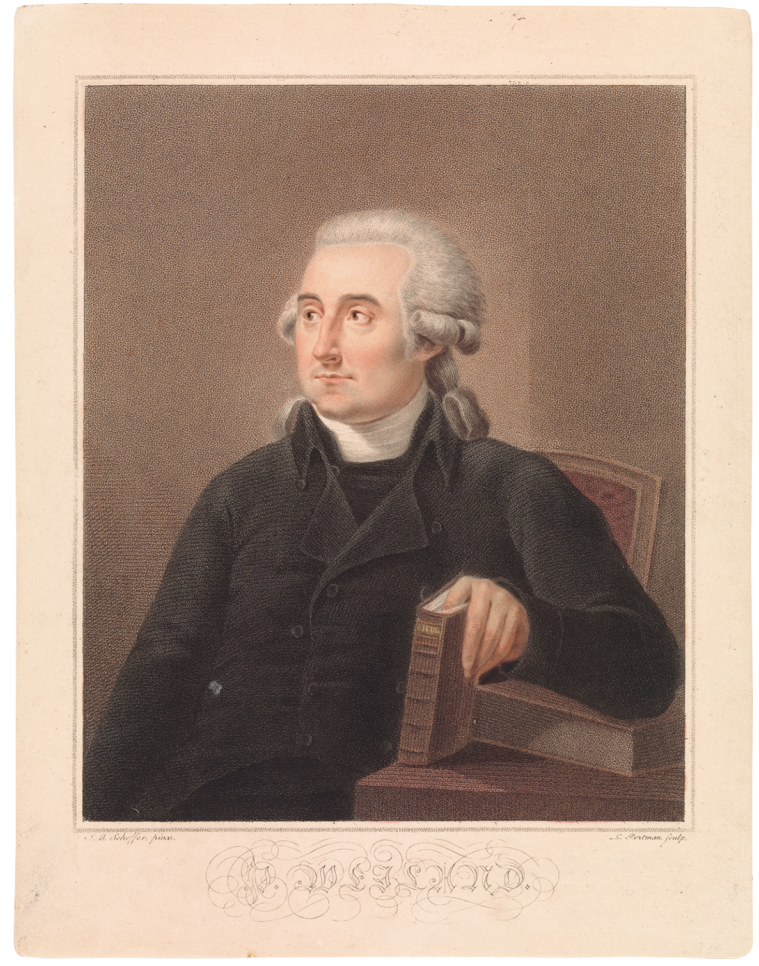

Figure 2. Pieter Weiland (1754-1842; by Ludwig Gottlieb Portman). Collection Rijksmuseum Amsterdam 
focus on morphology and constituents. The work can be seen as the end point of a long tradition of grammaticography that focused on the word with, for example, a strong interest in nominal case and nominal inflection, and with scant attention to syntax (Rutten 2009, cf. Noordegraaf 1985: 46). As with Siegenbeek's spelling, more concise versions of the grammar were published, among others by Weiland himself (cf. Weiland 1805b, 1820). Apart from Weiland's (1799) own 200-page introduction to the first volume of his dictionary, the main sources used by Weiland (1805a) were well-known works such as the Aenleiding tot de kennisse van het verhevene deel der Nederduitsche sprake ('Introduction to the knowledge of the elevated part of the Dutch language') by Lambert ten Kate (1723), and J. C. Adelung's Umständliches Lehrgebäude der Deutschen Sprache (1782; see Noordegraaf 2018).

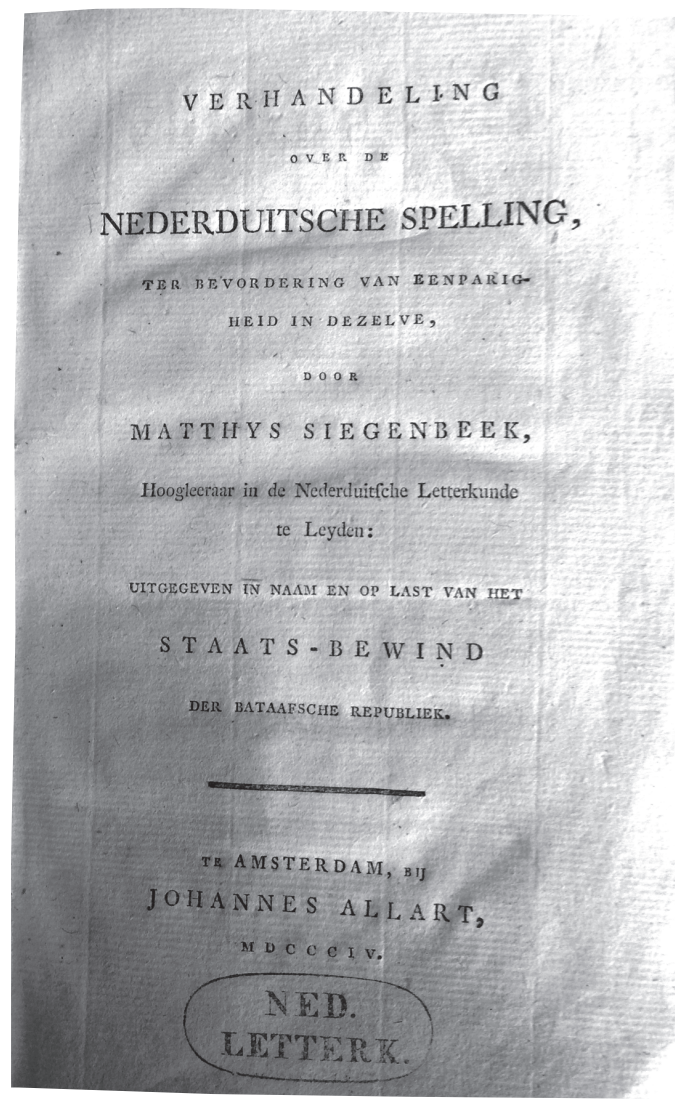

Figure 3. Title page of Siegenbeek's Verhandeling over de Nederduitsche spelling (1804a). Collection Leiden University 


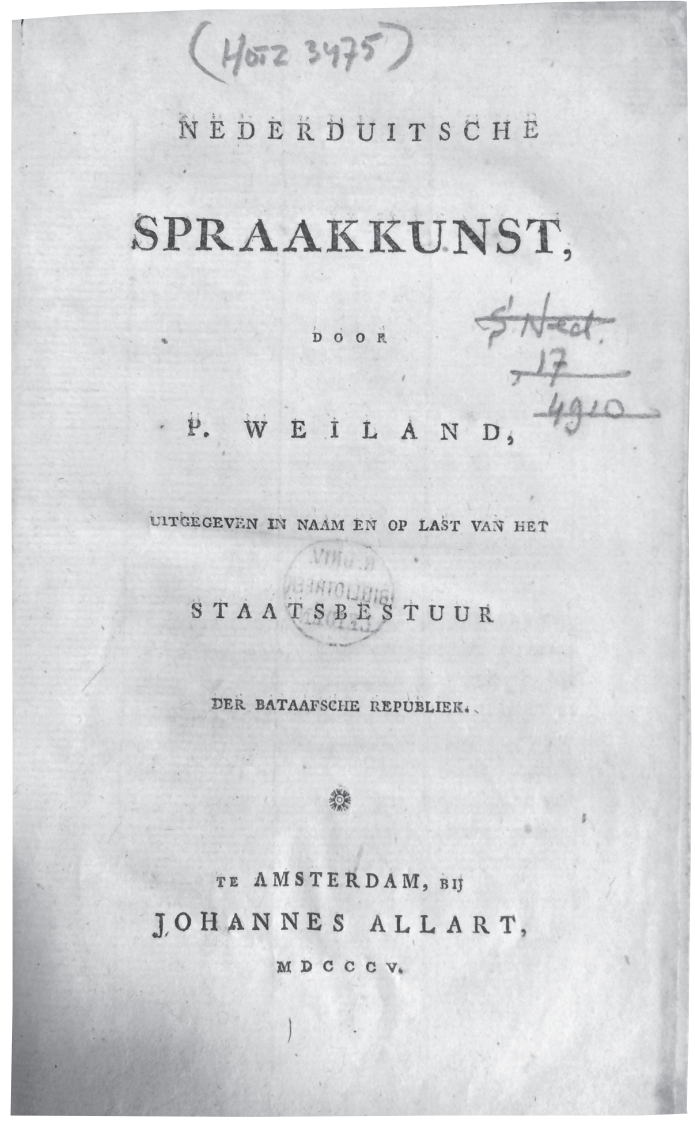

Figure 4. Title page of Weiland's Nederduitsche spraakkunst (1805a). Collection Leiden University

Weiland (1805a) is the only grammar that has ever been officially adopted by the Dutch government.

Before adopting Siegenbeek's spelling (1804a) and Weiland's grammar (1805a) as official publications of the national government, several rounds of peer review were organised. Siegenbeek and Weiland duly explained the whole procedure in the prefaces to their works (Siegenbeek 1804a: V-XX; Weiland 1805a: V-XVII). Among the peer reviewers were J. H. van der Palm (1763-1840), the minister of education who had commissioned the schrijftaalregeling, the aforementioned Kluit, another important language observer in the second half of the eighteenth century called Meinard Tydeman (1741-1825, cf. Noordegraaf 2012) and, in Siegenbeek's case, Weiland, and in Weiland's case, Siegenbeek. 


\subsection{Overview of the book}

The present study contextualises the crucial sociolinguistic event outlined in Section 1.2 from various angles, focusing on

- the historical-sociolinguistic context and the ideology underpinning the policy (Parts I and II)

- the institutionalisation of the ideology in various fields of metalinguistic discourse, resulting in discipline formation (Part III),

- the implementation of the policy in educational settings (Part IV), and

- the effects of the policy on actual language use (Part IV).

As such, the study aims to offer a comprehensive overview of the background, the implementation and the effects of the language policy. This volume thus focuses on the Dutch situation, but where appropriate I will make references to and comparisons with other European languages throughout the volume.

The time span covered by this study runs from c. 1750 to c. 1850. The ideology of nationalism developed from c. 1750 onwards. The written language regulation materialised in 1804 and 1805. In subsequent decades, the ideology and policy affected educational practices and metalinguistic discourse. An important issue is also whether the new language policy immediately influenced patterns of language use, i.e. already in the first half of the nineteenth century. Finally, from around the middle of the nineteenth century, both educational policies and language planning changed again, introducing new school systems and new spelling regulations.

Part I, 'Setting the stage', describes the historical, ideological and sociopolitical background that resulted in the official language policy of the early nineteenth century (Chapter 2). It also introduces the core concepts of the language ideological framework that is used in this study. Chapter 3 provides an analysis of the sociolinguistic situation in the Early and Late Modern period in the northern Low Countries, focusing on language use. The main claim is that this situation was diaglossic. Both chapters situate the Dutch case in a broader western European context. Chapter 4 discusses Dutch eighteenth-century metalinguistic discourse, specifically the tradition of normative grammar and how it developed in accordance with sociopolitical changes. A key issue is the discursive split of the linguistic continuum into standard and non-standard Dutch.

The politicisation of language in sociopolitical discourse and the development of 'Dutch' as a symbol of the 'Dutch' nation were accompanied by much language ideological work. Part II, 'Myth building', discusses important language myths, in particular the Golden Age Myth (Chapter 5) and the Myth of Neutrality (Chapter 6). These two language myths characterise the period around 1800, when they became 
imbued with political meaning, and live on until today, both in academic and lay perceptions of the Dutch language and its history.

Part III focuses on 'Discipline formation', shifting attention to various instances of institutionalisation in metalinguistic discourse that revolve around the discursive split into standard and non-standard Dutch. Chapter 7 analyses the many proposals for a new Dutch dictionary in the late eighteenth and early nineteenth centuries, discussing the discursive construction of 'Dutch' in lexicographical theory and practice. The rise of Dutch studies as an independent academic discipline is analysed in Chapter 8, where particular attention is paid to the works of Siegenbeek. Chapter 9 focuses on varieties of Dutch that were initially not part of the new academic discipline, viz. regional dialects. I will argue that the privileged focus on standardised and written Dutch was accompanied by a folklorising approach to non-standard language.

In Part IV, 'Perspectives from below', the implementation of the new language planning efforts is analysed. Chapter 10 focuses on the language-in-education policy and practices, determining the role of educational practices in the dissemination of the national standard. Another aspect of implementation concerns the influence of language planning on actual language use. Chapter 11 discusses the extent to which changes in the language can be related to the official policy, based on quantitative analyses of corpus data.

Chapter 12 summarises the main themes and offers future research directions. 

PART I

Setting the stage 



\section{CHAPTER 2}

\section{Language and nation in Late Modern times}

\subsection{Introduction}

This book is about the northern Low Countries in the late eighteenth and early nineteenth centuries, when nationalism became a dominant political ideology and nation-building an important political motive for policy makers. In this context, language developed into a symbol of the imagined northern Dutch nation, and was thus turned into a prominent field of interest for nation builders. Education, in particular, became a domain closely associated with language planning. In 1804 and 1805, the first official spelling and grammar of Dutch were issued (Siegenbeek 1804a; Weiland 1805a). The so-called schrijftaalregeling 'written language regulation' was ordered by the government of the Batavian Republic, and was to be used in the administration and in education.

This chapter gives a sketch of the historical, sociopolitical and language ideological situation to provide a background for subsequent chapters. Section 2.2 outlines the main political developments in the Early and Late Modern period, from the middle of the sixteenth century to the nineteenth century. The idea of the Dutch language symbolically representing the Dutch nation is the topic of 2.3. Sections 2.4 and 2.5 discuss education as a discursive and legal focal point in the late eighteenth and early nineteenth centuries.

\subsection{Political changes}

The focus on the northern Low Countries implies that this book is not about the southern Low Countries. ${ }^{1}$ The political split of the Low Countries into a northern and a southern part currently corresponding to roughly the Netherlands on the

1. For general overviews of the political and cultural history of the northern Netherlands in the Early and Late Modern period, see Israel (1996), Frijhoff \& Spies (1999) and Kloek \& Mijnhardt (2001). For historical-sociolinguistic studies of the southern Low Countries in the eighteenth and nineteenth centuries, see, for example, Vosters (2013), Vosters \& Vandenbussche (2012) and Vosters et al. (2014) and the references there, as well as Willemyns (2003) and Rutten (2011). Throughout the present book, references to the southern Low Countries will be made whenever appropriate. The main focus, however, is on the northern Netherlands. 
one hand, and Belgium and Luxembourg on the other, dates back to the second half of the sixteenth century. Historically, the Low Countries were a collection of duchies and counties that were brought together into the personal union of the Seventeen Provinces by Charles V (1500-1558), emperor of the Holy Roman Empire. In the fourteenth century, the western regions of Holland and Zeeland had already been part of the so-called Burgundian Netherlands. In the first half of the sixteenth century, eastern and northern provinces such as Friesland, Groningen and Gelre (Guelders) were integrated into what had become the Habsburg Netherlands. Around the middle of the century, opposition to the policies of Charles V's successor, Philip II of Spain (1527-1598), led to the Dutch Revolt. From a conglomerate

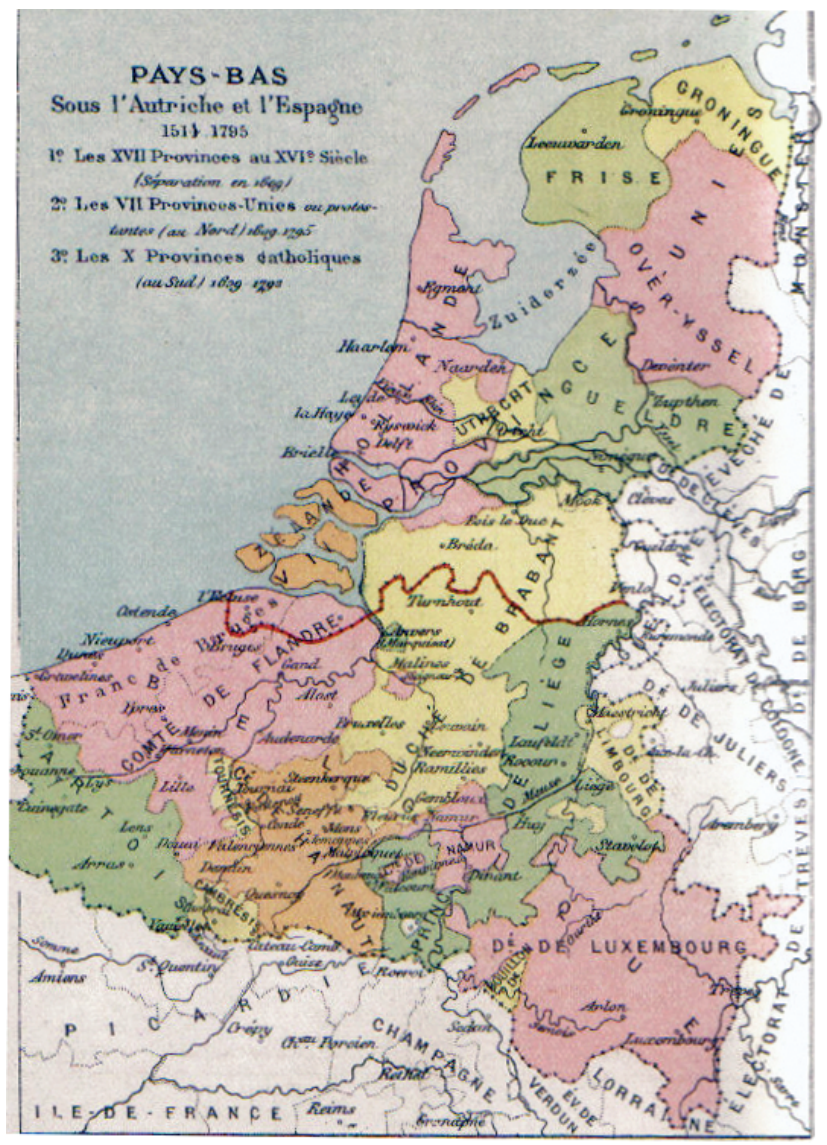

Figure 1. Historical map of the Habsburg Netherlands, taken from Alexis-Marie Gochet, Atlas de géographie physique, politique et historique à l'usage de l'enseignement primaire et de l'enseignement moyen. The red line separates the northern and the southern Netherlands. (Wikimedia Commons) 
of possible causes that have been suggested, the most important ones seem to be the Habsburg tendency to centralise policies, for example with respect to taxes and religion, resulting in opposition, particularly in the recently conquered territories in the north. The Dutch Revolt only ended with the Treaty of Münster, part of the Peace of Westphalia, in 1648. Politically, it led to a separation of the Low Countries into a southern and a northern part. The southern part remained under Habsburg rule, subservient to Philip II, and became the so-called Spanish Netherlands, and from 1714 onwards the Austrian Netherlands. The northern part had already formally declared its independence of Philip II in 1581 in the so-called Plakkaet van Verlatinghe 'Act of Abjuration'. From then on, the Northern Netherlands developed into the sovereign Republic of the Seven United Netherlands.

In the second half of the sixteenth century and the first half of the seventeenth century, traditionally called the Dutch Golden Age, the Dutch Republic acted as a uniform state internationally. Matters of war and peace and international diplomacy were responsibilities of the States General in The Hague. Despite the fact that the Republic was not officially recognised by other European states, ambassadors of the seven provinces were admitted to the peace negotiations in Münster. In the treaty between Spain and the Dutch, the Republic was officially recognised as a sovereign state. Foreign policy being in the hands of the States General, which moreover gradually increased its activities to include among others taxes, shipping, water management, religious affairs and colonial expansion, implied a certain amount of centralisation and contributed to a sense of unity. By 1650, however, "[o]nly an outsider could imagine that the Republic was a unity. Internally, it remained strongly divided" (Frijhoff \& Spies 1999: 605; my translation). Officially, the united provinces of the northern Low Countries consisted of a group of seven sovereign states, viz. Gelre, Holland, Zeeland, Utrecht, Friesland, Overijssel and Groningen. The region of Drenthe was autonomous, but without a vote in the States General. The provinces, in their turn, consisted of numerous counties, duchies, manors, and, importantly, towns and cities, which all had a greater or lesser level of autonomy in financial, legal and tax matters. Obviously, cultural and linguistic diversity was at least as significant, and even more so than today. The political situation has been characterised "as a cross between a federal state and a confederation" (Israel 1996: 306), and one that, established in the early seventeenth century, remained "basically unchanged" until the fall of the Republic in 1795 (Israel 1996: 305). Van Sas (2004: 47) likewise describes the political structure of the late eighteenth century as a particularistic and in that sense medieval form of government, which was brought to a sudden end by the formation of a national state. 


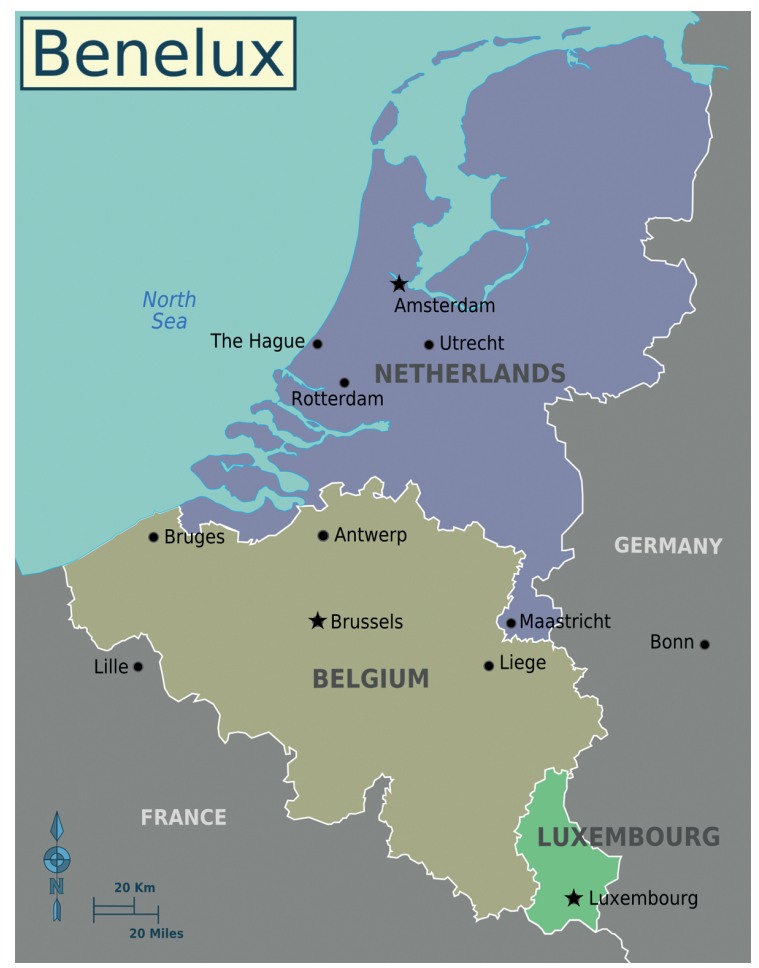

Figure 2. Map of the Benelux: Belgium, the Netherlands and Luxembourg. (Wikimedia Commons)

Apart from the provinces, the House of Orange was an important source of power in the Early and Late Modern period. In fact, the period is characterised by an enduring tension between the provincial states and the States General on the one hand, and the Stadtholders of the House of Orange on the other hand. In line with the strong republican current, two so-called stadhouderloze tijdperken 'stadtholderless eras' were established, the first (1650-1672) after the death of William II (1626-1650), whose son and heir William III was only born one week after his father's death, and the second (1702-1747) after the death of William III (16501702), who remained childless. William III bequeathed his possessions to his second cousin John William Friso of Nassau (1687-1711), whose son and grandson were William IV of Orange-Nassau (1711-1751) and William V of Orange-Nassau (1748-1806). William V was the father of William I (1772-1843), the first King of the Netherlands (1815-1840).

Mostly due to developments outside the northern Netherlands, the tension between republicans and royalists gave way to an opposition of unitarianism and federalism in the second half of the eighteenth century. William $V$ took up the position 
of Stadtholder in 1766. In 1780, with the beginning of the Fourth Anglo-Dutch War (1780-1784), republican opposition to the reign of Orange increased, and was intensified by the war turning into a disaster. Apart from the crushing defeat in battles, overseas possessions were lost and colonial trade suffered a tremendous loss. The following years were characterised by increasing tension between the republican patriotten 'patriots' and the royalist orangisten 'supporters of Orange'. The situation in various towns and cities in the west, including The Hague, became so virulent that William V and his wife Wilhelmina of Prussia (1751-1820) fled to the loyal city of Nijmegen in the east. In 1787, on her way back to The Hague, Wilhelmina was arrested by patriots. Considering this a serious insult, her brother Frederick William II (1744-1797), King of Prussia, decided to invade the Netherlands and restore the reign of Orange. The French Revolution of 1789 greatly inspired the republican and anti-Orangist feelings of the patriots, while it also promoted among them the idea of unitarianism. Previously, most patriots had been in favour of a federalist form of government. In the following years, the most important political difference was no longer between republican patriotism and Orangism, but between unitarianism and federalism.

In 1794-1795, the French invasion of the Austrian (southern) and northern Netherlands led to the flight of William. Backed up by the French, the patriots seized power and constituted the Bataafsche Republiek 'Batavian republic' (17951801), which was succeeded by the Bataafsch Gemeenebest 'Batavian commonwealth' (1801-1806), then by the Kingdom of Holland under Napoleon Bonaparte's (1769-1821) brother Louis Bonaparte (1778-1846). In 1810, Napoleon annexed the northern Netherlands to France, to which the Austrian Netherlands had already been annexed in 1795. The French invasion of the 1790s thus brought an end to the political split of the southern and northern Low Countries. The years 1795-1815 constitute the so-called French period, when the northern Netherlands were a vassal state of France, up to the incorporation into France in 1810, while the southern Netherlands were directly under French rule throughout the period. After the fall of Napoleon Bonaparte, the southern and northern parts were unified into the (United) Kingdom of the Netherlands, created as a buffer state against France at the Congress of Vienna in 1815. Luxembourg was also part of the Kingdom, albeit through a personal union. The Kingdom of the Netherlands disintegrated with the Belgian Revolution of 1830, when the present situation of three separate states was more or less established.

In the French period, the first northern Dutch national parliament, the Nationale Vergadering 'national assembly', was established and a form of suffrage was introduced that was unprecedentedly democratic, with the right to vote given to every man of twenty years or older who was neither on relief nor a domestic servant. One of the tasks of the new parliament was to design a new constitution. 
In 1798 , an unambiguously unitarianist proposal was adopted. While many changes of government would follow in subsequent years, the 1798 constitution laid the foundation for the Dutch nation state. In this period, it became apparent to many that a national government could pursue policies in domains that were previously not subject to intervention by the government. So-called agenten 'agents, ministers' were appointed, including an Agent van Nationale Opvoeding 'minister of national education', indicating that education had become a matter of national interest, which had important linguistic consequences as well.

When in 1805 the Netherlands had become a vassal state of Napoleonic France, the nationalisation of communal responsibilities continued. A national tax system was introduced and a series of laws for primary education were passed, announcing a national system of inspection and paving the way for a national educational system. Nationalisation continued with the introduction of penal and civil codes. After Napoleon's defeat in 1813, William I became King of the Netherlands in 1815.

Van Sas (2004: 41) stresses the importance of the 1790s and particularly of the 1798 constitution for the foundation of the modern Dutch nation state. He also stresses that the political unitarianism of this period by no means came out of the blue. It was "the political consequence of a process of cultural unification that had been going on for a few decades under the flag of the Dutch Enlightenment" (van Sas 2004: 42; my translation). In the northern Netherlands, nation-building and cultural nationalism preceded state formation. From c. 1750 onwards, a cultural process of nation-building developed, which was backed up by the formation of a national state in the 1790s so that the foundation of the Dutch nation state can be dated to c. 1800 (van Sas 2004: 44). The vernederlandsing 'Dutchification' (van Sas 2004: 54) of the Enlightenment in the second half of the eighteenth century meant that discussions about the Enlightenment primarily took place in a national context (cf. Porter \& Teich 1981). A dominant theme in Dutch Enlightenment discourse was the alleged decline of the Dutch Republic after the glorious seventeenth century, politically, economically and culturally, which concomitantly led to the construction of the national myth of the seventeenth century as a Golden Age (van Sas 2004: 54). Much Enlightenment discourse in the countless societies and periodicals offered a diagnosis of the national decline as well as concrete proposals to remedy it. The nationalisation of Enlightenment discourse was widening and restrictive at the same time, as van Sas (2004: 55) observes: while internal borders were ignored, the border with other European countries was emphasised. Similarly, Kloek \& Mijnhardt (2001) consider the rise of a national communication community to be one of the defining characteristics of the northern Dutch eighteenth century. A further crucial factor is that many of the proposals launched in Enlightenment discourse were immediately implemented in actual policies in the late 1790s and early 1800s. Exemplary in this context is the politicisation of language and education. 


\subsection{Language and nation}

The rise of cultural nationalism in the second half of the eighteenth century includes the rise of linguistic nationalism. Language played a prominent role in the efforts at and the pleas in favour of cultural unification, and the period thus witnessed the rise of a national language ideology. Such an ideology that aims to create a language that unifies the population is often also referred to as standard language ideology. Standard language ideology or SLI, discussed by Milroy \& Milroy (2012) and also explored in Milroy $(2000,2001)$, is analysed in great detail by Lippi-Green (1997), who defines it as "a bias toward an abstracted, idealized, homogenous, spoken language which is imposed and maintained by dominant bloc institutions and which names as its model the written language, but which is drawn primarily from the spoken language of the upper middle class" (1997: 64). Lippi-Green analyses SLI in the contemporary United States. This present book is historically oriented and focuses on the rise of SLI in the Netherlands in the second half of the eighteenth century, when the Dutch language underwent "nationalization" (Burke 2004: 166) or "totemization" and was "adopted as one of the defining social properties of a group" (Le Page \& Tabouret-Keller 1985: 263), viz. of the Dutch nation. This cultural idea of language as a symbol of the nation was politicised around 1800, when a homogeneous, normalised form was called for by the national government, which was to be used in the administrative and educational domains.

The fusion of different concepts such as language and nation into one conceptual framework, making them interdependent, was a widespread phenomenon in the eighteenth century, and a main topic in contemporary public discourse. The ultimate epistemological consequence of the interdependence of language and nation is linguistic relativism (or Whorfianism, or the Sapir-Whorf hypothesis), which is often traced back to the works of Wilhelm von Humboldt, such as Über die Verschiedenheit des menschlichen Sprachbaus und ihren Einfluss auf die geistige Entwicklung des Menschengeschlechts (1836; cf. Noordegraaf 1999: 344). Humboldt, however, had many well-known predecessors who discussed the intrinsic relationship of language and nation, including Etienne Bonnot de Condillac's Essai sur l'origine des connaissances humaines (1746), Johann David Michaelis's Von dem Einfluss der Meinungen eines Volcks in seine Sprachen, und der Sprache in die Meinungen (1760), Johann Gottfried Herder's Abhandlung über den Ursprung der Sprache (1772), and even further back in time the works of Giambattista Vico from the first half of the century, and John Locke's Essay concerning human understanding (1672) and Two treatises of government (1690) (cf. Christman 1966; Aarsleff 1974; Bauman \& Briggs 2003; Neis 2003).

Of these authors, Herder is often singled out as canonical, and considered to be a major representative of the conceptual fusion of language and nation, to 
which a third main concept should be added, viz. history. Herder is usually held co-responsible for a Copernican revolution in the semantic development of the Volk concept (Geschichtliche Grundbegriffe 1992: 283). He is thought to be the founder of the romantic concept of Volk or Nation as a collective individuality with a specific culture, which primarily manifests itself in poetry and language. This could be termed the ontological foundation of Volk. In addition, he is considered to be one of the originators of historicism, interpreting the history of mankind as the necessary development of distinct nations, which might be termed the historical foundation of the romantic Volk concept. According to Berlin (1976: 145), "he is the father of the related notions of nationalism, historicism, and the Volksgeist".

This is a well-known story that does not need to be retold here. Instead, I will focus on Dutch sources from the eighteenth century that discuss the concepts of language, nation and their inherent connections, illustrating the rise of linguistic nationalism (Noordegraaf 1999; Rutten 2004). A crucial and relatively early author was Meinard Tydeman (Noordegraaf 2012). In 1762, when he was only 21 years old, he wrote a short essay in which he argued that cultivating the moedertaal 'mother tongue' would greatly contribute to the well-being of society as a whole (see Tydeman 1775a). One of Tydeman's arguments concerned civil command of the language with regard to a democratic ideal of citizens speaking in vrije volksen raads-vergaderingen 'in free national and council meetings' (1775a: 6). In the interest of a smoothly running political system, he considered it to be important that members of the nation practise their language skills. In an essay of the previous year, 1761, Tydeman had advocated the foundation of a scholarly academy which would by order of the national government supervise the national education system (see Tydeman 1775b). Every schoolmaster should be subjected to a Dutch test, and should be forced to use in class a not yet existent brief grammar with the principles of the Dutch language, and to study a more extensive grammar in order to truly understand the principles (Tydeman 1775b: 17-19).

Also in the 1760s, Joan Jacob Mauricius published a thick book on the history and use of foreign words in various languages, including Dutch, in which the history of the peoples who speak these languages occupies an important place (Mauricius 1765). Mauricius uses the term Volk 'people', which he appears to conceptualise in a romantic Herder-like fashion. He frequently refers to Michaelis' prize essay Von dem Einfluss der Meinungen eines Volcks in seine Sprachen, und der Sprache in die Meinungen and the 1760 volume that it was first published in, the Dissertation qui a remporté le Prix proposé par l'Académie Royale des Sciences et Belles Lettres de Prusse, sur l'Influence réciproque du Langage sur les Opinions, et des Opinions sur le Langage. Avec le Pieces qui ont concouru (Mauricius 1765: 13, 42, 45, 53, 55, 59, 61). One of the claims made by Mauricius (1765: 55) is that de beschaafdheid en geestrykheid van een Volk altyd in eevenredigheid [is] met de rykdom en beschaafdheid van 
deszelfs taal 'the cultivation and ingenuity of a people is always in proportion to the wealth and cultivation of its language. This idea, which has been referred to as the These vom Weltbild der Sprache (Christmann 1966), was important from the middle of the eighteenth century onwards and well into the nineteenth century, and remains so even today. Within a few decades, it had become an idée reçue. When in 1819, Petrus Eekma wrote an introduction to Dutch linguistics, he considered the influence of the language op de zeden der menschen en's Lands wetten [...] reeds zedert langen tijd, eene aangenomene waarheid 'on the customs of people and the laws of the country [...] an accepted truth for a long time now' (Eekma 1819: III).

In 1771, a Dutch translation of Michaelis's essay was published (Michaelis 1771). Interestingly, the adjective nationaale 'national' is inserted into the title, signifying the interrelatedness of language and nation: Prysverhandeling over den wederkeerigen invloed van de aangenomen begrippen onder een volk op de nationaale taal, en van de taal op de nationaale wyze van denken ('Prize essay about the reciprocal influence of the accepted ideas of a people on the national language, and of the language on the national way of thinking'). On the whole, the translation appears to be quite faithful. However, the translator, Cornelis van Engelen, allows himself occasional interruptions to Michaelis's argument, which are reminiscent of Herder's Abhandlung, which would not be published until 1772, i.e. one year later. One telling example is when van Engelen inserts a passage on proverbs (Michaelis 1771: 6-9), and in particular on the way in which these demonstrate the linguistic preservation of the vorige levens-wyze des Volks 'earlier way of life of the people' (Michaelis 1771: 7). The ontological qualities of the people are borne by their language. Moreover, in another inserted passage, van Engelen claims that the etymology of some Dutch words reveals the theological outlook of the Dutch people, thus adding a historical dimension to the interrelatedness of language and nation.

Such Herder-like insertions into the translation of Michaelis's essay take on a new aspect when a few years later van Engelen shows that he has read his German contemporary. In 1775, a certain C.V.E., probably van Engelen, published an article on waarom de dieren niet spreeken, en hoe de menschen hebben begonnen te spreeken 'why the animals do not speak, and how man began to speak' (see C.V.E. 1775). The author refers to the essay competition organised by the Berlin Academy a few years before, where the origin of language was the main topic (Neis 2003), as well as to Herder's prize essay, admitting that he was not able to consult the essay itself and relied on review articles. He is, therefore, not able to provide the intended translation, and instead offers his own thoughts on the topic, interlaced with quotes from articles about Herder's Abhandlung. C.V.E's views turn out to be consistent with Herder's (cf. 1775: 199-230). From the tones that man originally used to express perceptions, and which are preserved in interjections, man has developed language due to the capacity to abstract from concrete situations and constitute 
ideas. Therefore, the historical development of language and knowledge go hand in hand, as with Herder's historical foundation of the romantic Volk concept. C.V.E. does not want to dwell on the reciprocal influence of language and opinions, since "Professor Michaelis before me has treated this part conclusively in his prize essay, and one knows the enlarged translation of this excellent work, which is available". C.V.E. thus advertises Cornelis van Engelen's translation of Michaelis.

As has already been mentioned, Herder's Abhandlung was published in 1772, as the winning entry to the Berlin essay competition of 1769. Mestingh (1771) was originally meant as a response to the prize competition as well, but he did not submit his essay to the Berlin Academy. The essay clearly reveals that Herder's Abhandlung provides but one example of a widespread theory of the origin of language in which interjections and onomatopoeia play a crucial role (cf. Neis 2003). Mestingh deduces the origin of language from the need to express emotions and passions to others, implying that interjections are the first words. In addition, people want to communicate thoughts to others. For example, by imitating the sound of a sheep one can make clear that a lost sheep has to be looked for, hence the word bleat comes into existence. This onomatopoeic origin of language leads to mostly monosyllabic words. These monosyllabic words are verbs denoting certain actions, such as the bleating of sheep. Therefore, verbs are the linguistic primitives from which nouns are derived (Mestingh 1771: 36-48). This theory including the example of the bleating sheep is almost identical to the opening passage of the "Dritter Abschnitt" of the first part of Herder's Abhandlung (Herder 1772: 44-48).

In 1772, the first volume of the Werken ('Works') of the Maatschappij der Nederlandsche Letterkunde ('Society of Dutch Language and Literature') appeared. This society was founded in 1766. In the preface to the first volume of the Werken, the society justified its existence and its goals, such as the study of the Dutch language, including the following statement:

Het kan den Liefhebberen van geleerdheid ook niet onbekend zijn, hoe veel invloeds de Tael op onze wyze van denken heeft; en hoe veel derzelver beschaving en uitbreiding toebrengt tot de juiste vorming, nette onderscheiding en klare uitdrukking van onze denkbeelden, en tot de wenschelyke vermeerdering onzer kundigheden.

(Werken 1772: $+2^{\mathrm{r}}$ )

It cannot be unknown to those who love erudition, how much influence the language has on our manner of thinking, and how much of its cultivation and elaboration contributes to the correct formulation, proper discrimination and clear expression of our ideas, and to the desirable accumulation of our knowledge.

2. C.V.E. (1775: 220): “de Hoogleraar Michaëlis heeft dat stuk in zyne Prysverhandeling voor my afgedaan, en men kent de vermeerderde vertaaling die van dit voortreffelyk Werk voor handen is". 
This quote once more expresses the linguistic relativism associated with the eighteenth century, in particular the idea that a nation's language determines its view of the world. In the Handelingen ('Proceedings') of the Maatschappij of 1774, which traditionally begin with a presidential address, repeated reference is made to the famous Johann David Michaelis, the great Michaelis, the judicious Michaelis (Handelingen 1774: 7-8) in a passage about the importance of cultivating the moedertaal 'mother tongue' or landtaal 'country's language, national language'. The reason why cultivation of the language is important lies in its interrelatedness to the nation itself as well as its level of erudition.

The inherent relation between language and nation, or in more contemporary terms between the national character (volkskarakter) and the characteristics of the language, is also exemplified in the works of Matthijs Siegenbeek, who authored the official spelling of 1804. In 1814, Siegenbeek published an essay on exactly this topic (Over het verband tusschen de taal en het volkskarakter der Nederlanderen 'On the relation between the language and the national character of the Dutch'). In it, he linked properties of the Dutch language on the phonological, syntactic and lexical level to moral characteristics of the Dutch people (see Chapter 8 for discussion).

In language ideological terms, the idea that a language mirrors the national character of its speakers, thus symbolising essential aspects of the nation, is a prototypical case of what Irvine \& Gal (2000: 37) call iconisation, which "involves a transformation of the sign relationship between linguistic features (or varieties) and the social images to which they are linked. Linguistic features that index social groups or activities appear to be iconic representations of them, as if a linguistic feature somehow depicted or displayed a social group's inherent nature or essence". The discursive construction of an iconic representation is composed of three theoretically independent ideological steps. The linguistic features or varieties, in our case the Dutch language, need to be perceived as a uniform whole. Similarly, the social group is subject to discursive homogenisation. Finally, and this is the real semiotic step of iconisation, these two entities are brought together into a symbolic relationship.

The iconic connections between language and nation as developed in Late Modern nationalistic discourse are dependent on four additional language ideological steps. Iconisation often co-occurs with erasure. Erasure refers to a discursive operation by which sociolinguistic space is simplified, as a result of which "[f]acts that are inconsistent with the ideological scheme either go unnoticed or get explained away" (Irvine \& Gal 2000: 38). The most basic way to conceptualise Late Modern erasure is to think of sociolinguistic space as consisting of one and only one variety, i.e. the national or standard language. Alternatively, sociolinguistic space was sometimes thought of as more varied, viz. as consisting of non-standard language in addition to standard language. The category of non-standard encompasses 
and demotes all variation outside the standard, often by elaborating on its threats to homogeneity, both linguistic and social.

Another important ideological aspect of iconisation is the pre-emptive discourse of authenticity, which is manifest in the ubiquity of moedertaal 'mother tongue' as a principal concept. The threat posed to homogeneity and uniformity by the existence of variation is neutralised by conceptualising the nation as a uniform whole, and by surrounding it with a naturalising discourse of the mother tongue. Thus, the national language is not just a symbolic, but also a natural and authentic representation of the nation (see Part II, where also anonymity is discussed, cf. Woolard 2008, 2016). By implication, non-standard language is not underpinned by an ideology of authenticity.

A third important ideological step is linked to history as the third crucial concept in the Herderian fusion of language and nation. The iconic relation of language and nation is often cast in historical terms. Nations are conceptualised as time-honoured entities, anchored in ancient times, and distinguishable from other nations by various cultural practices, such as their language (see also Chapter 5 on the Golden Age Myth).

The ideological backbone of discursive moves such as iconisation, erasure, authenticisation and historicisation is homogeneity, the idea that both language and nation are discrete and uniform entities, free from variation and change. In a study of language myths in the history of English, Watts (2012: 595-596; cf. Watts 2011) calls the myth of homogeneity the "underlying" language myth, i.e. the foundation on which other language myths are built, for example myths of the longevity of English, of language purity, and of polite language. In a detailed discussion of the language ideologies of Herder and Locke, which are very different in many respects, Bauman \& Briggs argue that they "converge in denying the legitimacy of multiple voices and multiple languages in public discourse [...] This ideology of a monoglot and monologic standard has provided a charter [...] for homogenizing national policies of language standardization and the regulation of public discourse" (2003: 195). The main idea in Blommaert \& Verschueren's (1998) seminal study is that diversity is an inherently problematic concept in the modern period, precisely because it opposes the ideal of homogeneity. In a historical analysis of Spanish, del Valle \& Gabriel-Stheeman (2002) also identify homogeneity as one of the main concepts in nineteenth-century linguistic nationalism. Homogeneity applies to the nation as well as to the language. One of the key instruments in nation-building to attain both social and linguistic homogeneity is education. 


\subsection{Education}

The reconceptualisation of language as a national symbol had political consequences. Language became an object of political control, for which national policies were developed. The official spelling and grammar regulations of 1804 and 1805 are the prime examples of this politicisation of language (Siegenbeek 1804a; Weiland 1805a). In their discussion of Herder's and Locke's language ideologies, Bauman \& Briggs (2003: 191-195) draw attention to another point of convergence: in addition to homogeneity, both authors share a discourse of social inequality. The Lockean ideal of a rational, purified, objective language is attainable by men, but the success rate is conditioned by factors of occupation, class and gender. The Herderian ideal of a poetic language expressing the Volksgeist is inherently connected to the Volk as a homogeneous entity, from which, however, the rabble and women were excluded. This means that the national language was a social privilege.

The national language, however, was also a goal. The Dutch Enlightenment is characterised by a fixation on education. Education became an object of political control, too, and was seen as a powerful tool to homogenise the population. The dissemination of the national language, previously the privilege of certain social groups, through education was part of this nation-building policy. In other words, there was a clear educational aspect to the official language policy that led to the 1804 and 1805 spelling and grammar. These language-in-education policies can be seen as the immediate result of the many debates on the education of man characterising the second half of the eighteenth century, and in particular the public and semi-public sphere of periodicals and societies (Rutten 2012). From the 1760s onwards, intellectual societies had engaged in prize contests on the moral and physical education of man (Los 2005). In 1784, the Maatschappij tot Nut van 't Algemeen, or: 't Nut ('Society for Public Advancement') was founded, which adhered to an explicitly inclusive ideology of public civilisation. The inclusive ideal does not imply an ideology of equality. Instead, it is the duty of the privileged groups to integrate the less privileged into the nation.

The ideal of inclusive citizenship was also at the heart of the contemporary government, and education was seen as a means to create national unity. A national educational policy was called for (Boekholt \& De Booy 1987: 95-96). In 1796 , the government turned to 't Nut to obtain expert advice on educational reforms. In 1798, 't Nut published its influential report Algemeene denkbeelden over het nationaal onderwijs ('General ideas on national education', see Dodde 1971), generally considered "the climax of three decades of discussion about education", which would lay "the foundation for reflection on the relations between state, citizen and education for the next century and a half” (Kloek \& Mijnhardt 2001: 287; 


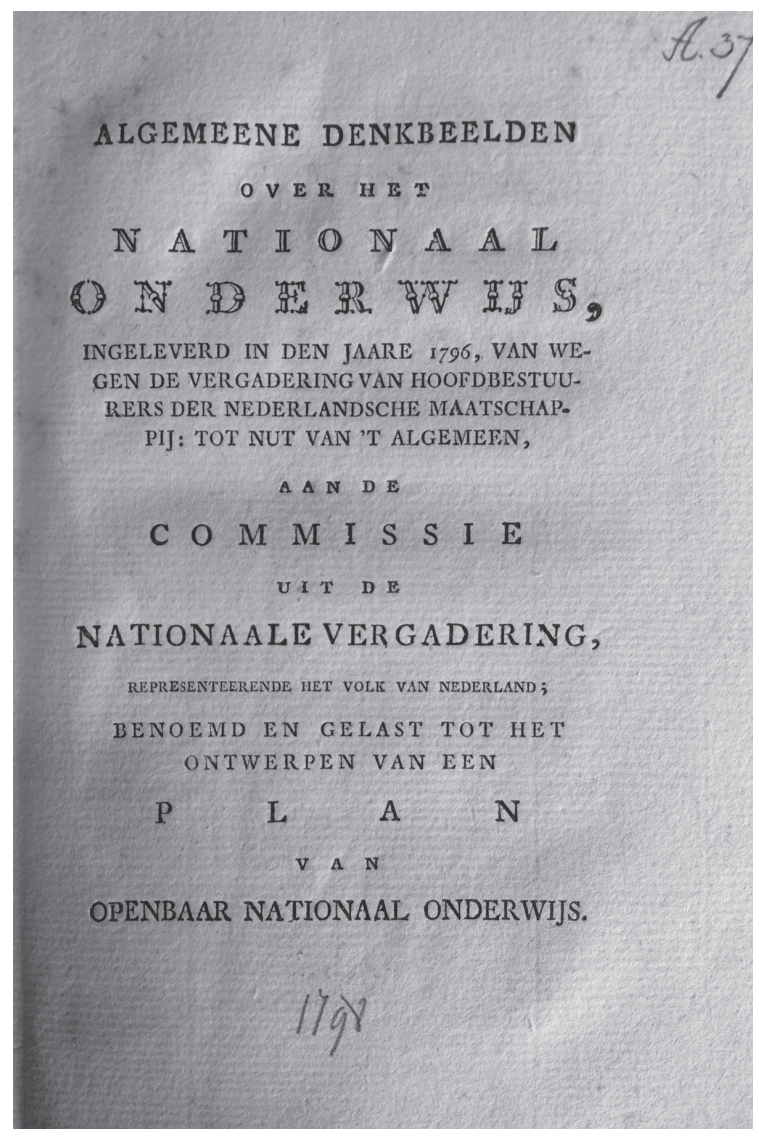

Figure 3. Title page of the Algemeene denkbeelden over het nationaal onderwijs (1798).

Collection Leiden University

my translation). In this report, 't Nut argued that mother-tongue education was indispensable for the national school system, and that grammar should be taught in schools (Lenders 1988). What characterises language policy in the early nineteenth century is the conviction that a newly codified national language should be taught to children for the benefit of the nation. Language policy in this period is essentially linguistic nation-building.

In her classic analysis of standard language ideology in the United States, Lippi-Green (1997) pays much attention to the manifold implicit and explicit ways in which the standard language is imposed on speakers, for example through education and the media, as a consequence of which speakers are exposed to a rigid ideological division of sociolinguistic space into standard and non-standard. It is also in the period around 1800 that we find the first explicit rejections of non-standard 
Dutch, a category that is only created through such rejections. From 't Nut stems the well-known treatise by van der Ploeg called Het belang der waare volksverlichting ('The importance of the true enlightenment of the people'), which was published in 1800. Van der Ploeg (1800: 10-11) stresses the inclusiveness of his idea of the people, which encompasses all social layers and both men and women. The topic of his essay is how to educate the people in such a way that they will be able to live their lives in physical and moral well-being, a goal which is politicised and nationalised in his reference to the people as the gezamenlijke burgers van den Staat 'the collective citizens of the state' (1800: 10-11). The members of the nation state should be subject to "de verbanning der zogenoemde - platte taalen" (1800: 129), i.e. the expulsion of the dialects, while simultaneously adopting the official and national language (1800: 32-33, 89-90, 129-130). This plain action against the dialects, overtly aimed at their eradication, recalls contemporary French language planning initiatives aiming at the spread of standard French at the expense of local varieties (de Certeau et al. 1975). Van der Ploeg does not restrict his proposal for a new language-in-education policy to the acquisition of a written supraregional variety. Instead, he argues that the use of other varieties than the national language will keep people from "enlightenment", the rich rewards of which are spread through spoken and written forms of de reine moedertaal the pure mother tongue' (van der Ploeg 1800: 89), not through dialects. What is more, dialects are denied the status of mother tongue. These speakers' actual mother tongue is the national language by virtue of their membership of the Dutch nation, from which perspective it becomes clear why van der Ploeg (1800: 129-130) goes so far as to demand from school teachers that they take care that children only use de zuivere Moedertaal 'the pure mother tongue', not just at school, but also among each other and at home with their parents.

\subsection{Policy}

Eighteenth-century educational discourse became politicised in the 1790s and in particular with the constitution of 1798 (Section 2.2). The constitution provided for eight agenten 'agents, ministers', six of whom were concerned with internal and external safety and finances (van Hoorn 1907: 6). The seventh agent had Nationale Oeconomie 'national economy' as his domain, i.e. trade, industry, fisheries, agriculture. The eighth agent was concerned with Nationale Opvoeding 'national education', which encompassed public health, de vorming der Nationale Zeden 'the formation of national morals', and the advancement of public education, the arts and the sciences (van Hoorn 1907: 6). 
The establishment of a ministry with the specific task of developing a national education system was a direct consequence of the Enlightenment discourse on language, nation and education. The Algemeene denkbeelden were commissioned by the national parliament, which transformed the discourse into concrete political action. The Algemeene denkbeelden (1798:5) had argued that members of the Maatschappij 'Society' had certain obligations both as human beings and as citizens. The fourth and fifth obligations related to religious and legal duties. These were, however, preceded by three obligations closely linked to education, and even more specifically to certain school subjects. The third obligation was that every member of society should have enough knowledge of arithmetic to handle his own affairs. The first two obligations were to understand de Taal van het Land 'the language of the country', and to be able to express thoughts in writing. In short, the Algemeene denkbeelden had argued that the education system should come under national political control, and that specific attention had to be paid to the dissemination of the national language (Dodde 1971: 12; Lenders 1988: 36-38). As such, the Algemeene denkbeelden argued for top-down policy measures involving status planning, corpus planning and acquisition planning.

Next, the national parliament designed an Instructie voor den agent van nationale opvoeding ('Instruction to the agent of national education'), which summarised the tasks of the new minister (Boekholt \& de Booy 1987: 97). He was to enact a law that would regulate school attendance in order to advance de verlichting en beschaving van alle de Leden der Maatschappy 'the enlightenment and cultivation of all members of society' (Instructie 1799: 3). The minister also had to provide a list of books to be used throughout the country - books that would praise good morals, republican virtues and love of the fatherland, among other things (Instructie 1799: 4). Furthermore, he had to establish teacher training colleges, teacher exams and a school inspection system (Boekholt \& de Booy 1987: 97). A whole range of other duties were mentioned, for example exercising control of theatres and the arts, which were supposed to foster good manners and the national character (Instructie 1799: 8-9). In 1801, 1803 and 1806, the agent of national education issued three laws for national primary education (Boekholt \& de Booy 1987: 97-101), that were strongly influenced by the educational discourse of the preceding decades, and by the Algemeene denkbeelden in particular, specifically with respect to the general aims of education, its organisation and the teaching methods (Los 2005: 324-325).

With respect to language, the Instructie (1799: 6) had said: Hy zal alle mogelyke middelen beramen, om de Nederduitsche taal te zuiveren, te beschaven, en derzelver spelling op eenen gelyken voet interigten 'He will take all possible measures to purify and cultivate the Dutch language, to regulate its spelling. The background of this particular order to the agent of national education was probably the complaint in the Algemeene denkbeelden (1799:6) that an eenvouwige, doch 


\section{N S T R U CTIE}

VOOR DEN AGENT DER

\section{NATIONAALE OPVOEDING,}

\section{WAAR ONDER BEGREEPEN IS DE GENEBSKUNDIGE \\ StaAtsRegeling, DE Vorming Der NATIO- \\ NAALE ZEDEN, DE BEVORDERING VAN HET \\ OPENBAAR ONDERWYS, EN VAN KUNSTEN \\ IN. WETENSCHAPPEN. \\ Den 18. October 1798.}

Het vierde Jaar der Bataffche Vryheid.

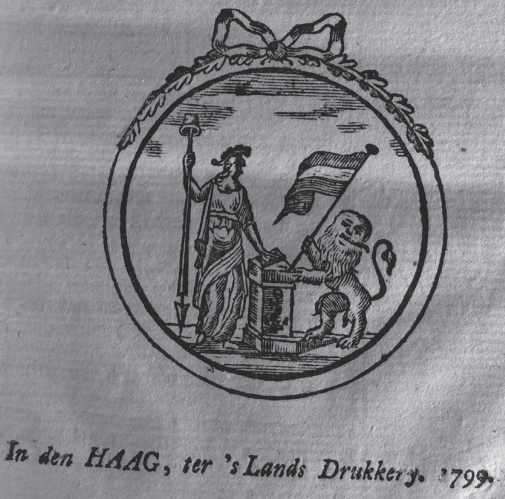

Figure 4. Title page of the Instructie voor den agent der nationaale opvoeding (1799). Collection Leiden University

zaaklijke, Nederduitsche Spraakkunst 'an easy yet adequate Dutch grammar' was still required. In fact, 't Nut had already called for a concise grammar of Dutch a few years before (Noordegraaf 1975: 121). Lambertus van Bolhuis, a learned clergyman from Groningen, submitted a Beknopte Nederduitsche Spraakkunst ('Concise Dutch grammar'), which was awarded the gold medal, and was printed in 1793. Van Bolhuis' Beknopte Nederduitsche Spraakkunst was a revision of an earlier publication. In 1776, van Bolhuis had edited the grammar composed by the late schoolteacher Klaas Stijl. From the Gedenkschriften ('Memoirs'), published in 1809 on the occasion of the 25th anniversary of 't Nut, we know that van Bolhuis's concise grammar was considered to be useful for the improvement of schools in general (Gedenkschriften 1809: 90), but it was not considered a suitable text for use in schools. In other words, it may have been helpful to teachers, but it was not a 
textbook for children. ${ }^{3}$ Therefore, 't Nut was still in need of a concise grammar of Dutch when it published the Algemeene denkbeelden. In 1799, 't Nut finally published its own grammar, anonymously, written by Gerrit van Varik.

These facts were briefly referred to when Matthijs Siegenbeek, professor of Dutch in Leiden, published the national spelling in 1804. In the introduction, he explained that the minster of education, J. H. van der Palm, professor of oriental languages in Leiden, had contacted leading figures of a few important private societies, such as 't Nut (Siegenbeek 1804a: XVIII-IX). In October 1801, a small circle of learned men came together at van der Palm's house, and decided to ask Siegenbeek to write the national spelling and Pieter Weiland, a minister based in Rotterdam, to write the national grammar. In 1800, the Leiden and Rotterdam societies Kunst wordt door Arbeid Verkreegen ('Art is Acquired through Labour') and Studium Scientiarum Genitrix had merged with the Amsterdam society Wij Streeven naar de Volmaaktheid ('We Strive for Perfection'), and had formed the Bataafsche Maatschappij van Taal- en Dichtkunde ('Batavian Society for the study of Language and Poetry') (Honings 2011: 127). The Batavian Society brought these men together into a formal network. Siegenbeek, who was probably also chosen for his profession, was its president. Weiland had published the first volume of his Dutch dictionary in 1799, to which he had added a concise grammar of Dutch, which would form the basis of his 1805 grammar (see also Chapter 7). The spelling and the grammar were adopted by the Batavian Society (Siegenbeek 1804a: X-XII). In order to increase the support for and the authority of the spelling, Siegenbeek then sent it to the aforementioned Maatschappij der Nederlandsche Letterkunde, also based in Leiden, which likewise adopted it (Siegenbeek 1804a: XII-XIV).

In December 1804, the national government decided to publish Siegenbeek's spelling in its name and to subsidise it, to use it in all governmental publications, to encourage the entire administration to adopt it in other writings as well, to prescribe its use in school books, and to ask school inspectors to implement it in the educational system (Siegenbeek 1804a: XVI-XVII). In August 1805, the government took the same decisions with respect to Weiland's grammar, which had first undergone a similar process of approval by the Batavian Society and the Maatschappij der Nederlandsche Letterkunde (Weiland 1805a: V-XII).

3. On the contrary, it was used at the University of Franeker (Noordegraaf 1997), see also Section 8.1. 


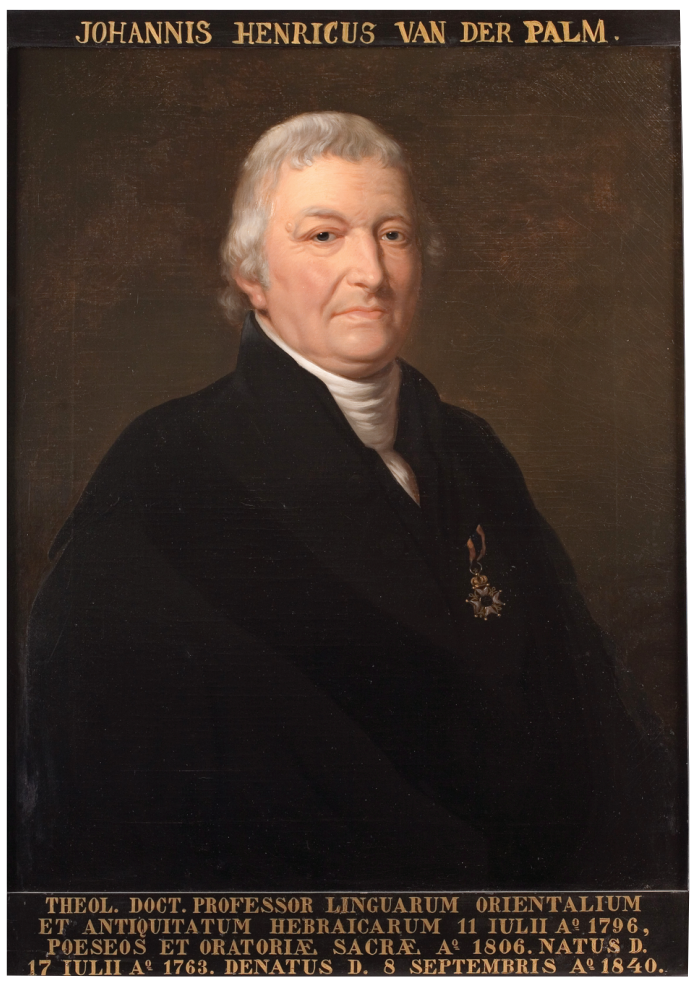

Figure 5. Johannes Henricus van der Palm (1763-1840; unknown artist). Collection Leiden University

\subsection{Final remarks}

In the eighteenth century, the discursive construction of the Dutch nation co-occurred with the discursive construction of Dutch as the national language, and as the mother tongue of all the members of the Dutch nation. Discussions on such topics as well as about the importance of education often took place in intellectual periodicals and within societies such as the Maatschappij tot Nut van 't Algemeen (founded in 1784) and the Maatschappij der Nederlandsche Letterkunde (founded in 1766). Ideas developed within these circles were implemented in the intense period of state formation in the 1790s and 1800s, so that the development of the Dutch nation state is often situated in this relatively short timespan. The idea of a national language immediately became politicised and led to an official language policy and a language-in-education policy in the first decade of the nineteenth century. The laws that resulted from fifty years of Enlightenment discourse on the language, the nation and education constitute the turning point around which the present study is composed. 



\section{CHAPTER 3}

\section{Sociolinguistic space}

\subsection{Introduction}

The previous chapter gave a broad outline of the historical, ideological and sociopolitical background of nationalist language policy and language-in-education policy in the northern Netherlands in the eighteenth and early nineteenth century. What was the linguistic situation in which policy makers tried to intervene? How heterogeneous was the language that became the object of the ideal of homogenisation? What was the sociolinguistic space like at the time? The vast body of historical sociolinguistic studies carried out over the past few decades may help find an answer to this question. I will situate the Dutch case in a broader Western European perspective, with particular reference to German and English.

Sociolinguistic space is understood here as the complete varietal spectrum from base dialects to the standard or hyper-standard that language users have at their disposal at a given place and time. With respect to the situation in the Netherlands, I take into account only the Dutch language. In other words, whereas French and Latin, to name but two other languages, were important parts of the sociolinguistic space in the Netherlands, I will not discuss them but will instead focus solely on Dutch. Nor will I give an overview of all the variants and varieties that language users had at their disposal, as this is not a historical grammar of Dutch. Taking recent historical sociolinguistic studies as my point of departure, I will discuss possible generalisations about the sociolinguistic space in the seventeenth and eighteenth centuries. The main argument will be that we need to think of the situation as diaglossic.

Obviously, my focus is on the written language. Apart from actual language use and the patterns found therein in terms of relative frequencies, implicit and explicit norms are also part of sociolinguistic space. Implicit norms or community conventions can be found through an analysis of usage data. This may also apply to explicit norms, but these too are part of metalinguistic discourse. The issue of norms, norm convergence, supralocalisation, prescription and standardisation will be discussed here in general terms. In Chapter 4 about metalinguistic space, I concentrate further on metalinguistic discourse, focusing on the tradition of normative grammar and on specific norms and prescriptions. 
Section 3.2 discusses the principal concept of diaglossia. Section 3.3 presents case studies from English and German. Section 3.4 focuses on Dutch. In 3.5, I discuss the important concept of supralocalisation, which I find useful to refer to supralocal usage patterns or writing traditions in a period when it is not fruitful to talk about standardisation. Section 3.6 focuses on codification as a significant metalinguistic phenomenon, and as an increasingly important part of sociolinguistic space. Section 3.7 argues that the diaglossic situation established for Early and Late Modern languages such as Dutch was provided with an extra metalinguistic layer that simplified the sociolinguistic space and reconceptualised it as diglossic.

\subsection{Diglossia and diaglossia}

The concept of diaglossia was reintroduced into sociolinguistic theory by Auer (2005) in a study of present-day dialect/standard constellations in Europe. Diaglossia refers to a situation with "intermediate variants between standard and (base) dialect" (Auer 2005: 22), thus breaking down the dichotomy implied by dialect/ standard diglossia. Offering a general description of the sociolinguistic situation in many language areas in Europe today, the concept of diaglossia brings together phenomena often described in terms of regiolectisation, destandardisation and substandardisation. According to Auer (2005: 23), diaglossia is a relatively recent phenomenon dating back to the late nineteenth or early twentieth century, following a previous stage of dialect/standard diglossia. I will argue that the sociolinguistic situation of many European languages in the Early and Late Modern period cannot be described in terms of diglossia, and is characterised by a ubiquity of intermediate variants instead. This means that diaglossia should be extended much farther back in time. This suggestion was also made by Dossena (2012: 2627). Likewise, Nevalainen (2012: 130-131) claims that diaglossia is a much older phenomenon, and in fact a useful concept to describe the sociolinguistic situation in Late Medieval England.

Auer (2005: 22) argues that in many present-day European language areas, "the space between base dialect and standard" (Auer 2005: 22) is filled with intermediate forms that are neither distinctly dialectal nor standard. A well-known example is Estuary English (Altendorf 2003). In the Dutch language area, colloquial varieties exist both in the south and in the north, reflecting the pluricentricity of the language area (Geeraerts \& Van de Velde 2013). The most strongly debated intermediate variety is without any doubt the so-called tussentaal 'in between language' used in Flanders.

Such intermediate forms enable language users "to act out, in the appropriate contexts, an identity which could not be symbolised through the base dialects 
(which may have rural, backwardish or non-educated connotations) nor through the national standard (which may smack of formality and unnaturalness and/or be unable to express regional affiliation)" (Auer 2005: 23). To refer to these intermediate forms, Auer $(2005,2011)$ uses diaglossia and diaglossic repertoire instead of regiolect and regional dialect, because "the implication [of the morpheme -lect, GR] that we are dealing with a separate variety is not necessarily justified" (2005: 22). Like diglossia, the notion of diaglossia conceptualises a community's sociolinguistic repertoire at a given place and time. As such, it offers a general description of the varietal spectrum synchronically available to language users without making claims about the regional or social origin of the various intermediate forms. In Europe today, diaglossic repertoires are found everywhere, from Norway to Cyprus and from Poland to Spain (Auer 2005).

Auer $(2005,2011)$ presents a typological and historical analysis of the rise of diaglossic repertoires in Europe. The typological development runs from a previous state of diglossia to diaglossia. The diglossic phase is first characterised by an exoglossic standard such as Latin, Church Slavonic or Arabic, and vernacular spoken varieties. This situation is found throughout Medieval Europe. ${ }^{1}$ Then there is a transition to a situation with an endoglossic standard, which is structurally related to the vernacular. The rise of endoglossic standards can be traced back to the fourteenth century (Auer 2005: 14). These are first mainly written, later also spoken. The endoglossic standards subsequently make their way into the spoken language, a phase that Auer (2005: 17) locates in the Early and Late Modern Period, between the fifteenth and the nineteenth century. Next, diaglossia may develop from the situation with an endoglossic standard roofing the spoken dialects, for example through dialect-to-standard advergence or through destandardisation, in which case regional elements are increasingly tolerated in the standard (Auer 2005: 25). The emergence of diaglossic repertoires is considered to be "a relatively late phenomenon, usually of the late nineteenth or early twentieth century" (Auer 2005: 23).

1. Like Auer $(2005,2011)$, I focus primarily on dialect/standard continua. The sociolinguistic situation in Medieval and post-Medieval Europe was more complex, however. Multilingualism was widespread; the importance of French in domains such as international trade and diplomacy is well known. Before endoglossic standards came into use, exoglossic standards such as Latin, Church Slavonic and Arabic were used (Auer 2005: 9), which often remained important after endoglossic standards had developed. Exoglossic norms were also part of the sociolinguistic situation. These often influenced codifications even in the Early and Late Modern period. Nevalainen (2012: 132), for example, points out that Latin and French spelling conventions left their marks on the incipient endoglossic standards of English. In Dutch, Latin-based morphological norms including four to six cases were prescribed well into the nineteenth century, despite the loss of inflection that had already set in in the medieval period (e.g. Simons \& Rutten 2014). 


\subsection{English and German diaglossia}

Following Dossena (2012) and Nevalainen (2012), I have argued that diaglossia is a much older phenomenon than proposed by Auer $(2005,2011)$, and that historical sociolinguistic studies have shown that the linguistic situation in Early and Late Modern Europe was diaglossic rather than diglossic (Rutten 2016a, 2016b). Much historical sociolinguistic work has focused on the Early and Late Modern Period, when according to Auer's historical scenario European dialect/standard constellations were characterised by diglossia, with spoken dialects on the one hand and endoglossic standard languages on the other. However, the Early and Late Modern Period displayed a much wider range of variation with many intermediate forms in between dialect and standard, and should be characterised as diaglossic instead. Case studies of Early and Late Modern English and German show that regional, social and register variations were considerable.

Auer (2005: 14-18) says that the spread of standard languages over the language areas in post-Medieval Europe depended among other things on regional and social factors. As a consequence, variation was an inherent aspect of the incipient standards. In those cases where a spoken standard developed out of a preceding situation with a written standard and spoken dialects, codification needed to be extended to a new domain, viz. speech, which was not codified in writing and was "difficult to enhance in a large area" (Auer 2005: 16). Auer goes on to argue that codification of speech has often remained imperfect, and that nowadays spoken standard languages generally display more inherent variability than written standard languages. I will argue that there is more to the variation found in written sources from the past than only the relative success with which standard norms are adhered to. The case studies reported on are founded in sources relatively close to the spoken language, such as private letters. It is important to point out beforehand that these do not display transliterated dialect (Elspaß 2007: 152; Rutten \& van der Wal 2014: 73). They are written in an at least partially deregionalised variety (see also Section 3.5).

Many studies demonstrate the existence of regional variation in the written language of the Early and Late Modern period. Nevalainen \& Raumolin-Brunberg (2003: 157-184) discuss fourteen grammatical changes on the basis of the Corpus of Early English Correspondence, ${ }^{2}$ which spans the period from c. 1410 to 1681. Most of these fourteen variables show clear regional patterns. The replacement of the subject form ye by you, for example, was a change that was led by the capital region. In the years $1520-1559$, in particular, the proportion of you was c. $40 \%$ in letters linked to London and the Court, while it was used less than $15 \%$ of the time

2. CEEC, see www.helsinki.fi/varieng/CoRD/corpora/CEEC/index.html. 
in East Anglia and the North (Nevalainen \& Raumolin-Brunberg 2003: 172). The replacement of the third-person singular indicative suffix -th by $-s$, on the other hand, spread from the North, where the incoming variant was already dominant in the mid-fifteenth century, while it only became the main variant in London and at the Court by the end of the seventeenth century (Nevalainen \& Raumolin-Brunberg 2003: 178). Interestingly, there is a dip in the frequency of $-s$ in the early sixteenth century, which Nevalainen \& Raumolin-Brunberg explain with reference to the simultaneous spreading of the southern form - th. This means that the two variants were in competition over a considerable stretch of time, and that we are witnessing, in the written language, two concurrent and conflicting processes of supralocalisation, referring to the regional spread of linguistic features beyond their region of origin (see 3.2 for further discussion). In the case of -th and $-s$, two features originating in different regions of England are simultaneously spreading to other regions than where they were native.

Similar examples can be found in the Late Modern period. Fairman's (2007a, 2007b) studies of eighteenth- and nineteenth-century English pauper letters show that there was an extreme pool of variation, extending well beyond what could be regarded as variation within a relatively uniform standard. In the same vein, McColl Millar (2012), analysing English private letters from the first half of the nineteenth century, argues that many of the linguistic features found in the documents are not in line with the standard of the time. However, they cannot simply be considered dialectal. Features such as the variable use of $h$ in initial position (I ham), the variable use of $r$ (Brothe, farther 'father'), multiple negation (he never send no word to them) and $a$-ing progressives (you was a speaking) are not localisable in Lancashire, where the writers in his letter collection came from (McColl Millar 2012: 170-173).

With regard to the nineteenth century, the most extensive study of language variation and change on the basis of private letters is probably Elspaß (2005). One case study concerns the use of the comparative particle (Elspaß 2005: 284-292). The broad development in High German is often characterised as running from denn 'than, then' as in besser denn 'better than' to als 'as' as in present-day standard High German besser als. Both in historical texts and in present-day dialects, other variants are found, including wie 'how' and als wie 'as how'. Using a large corpus of nineteenth-century private letters, mainly written by emigrants to the United States, Elspaß finds all four variants. Delving into their regional distribution, two things stand out. First, that some regional patterning can be discerned, indicating regional writing practices (Elspaß 2005: 288). Secondly, and even more importantly, that the regional distribution is not entirely in line with the situation in present-day dialects, with, for example, wie and als wie being used by writers from the northern and western parts of the German language area, whereas als is clearly dominant and is often the only variant in present-day dialects (Elspaß 2005: 288-291). Moreover, 
many writers used multiple variants, including one schoolteacher who used all four options in two letters from 1858. This leads Elspaß to assume that there were supralocal writing conventions that differed both from local dialects and from the prescribed language of the time (Elspaß 2014).

A similar case in point is diminutive formation, where the broad development in the eighteenth and nineteenth centuries runs from -gen to -chen; compare the attested form Metgen (1858, cf. Elspaß 2005: 344) and present-day standard High German mädchen 'girl'. Elspaß (2005: 344-345) argues that the many instances of 'non-standard' -gen in his nineteenth-century corpus, particularly in letters linked to the west and northwest of the language area, cannot be interpreted as interference from the spoken language as this is a purely orthographical variable. Instead, the persistent use of -gen signals a writing convention that continued to be transmitted from generation to generation, despite the fact that -chen had become the 'standard' form decades before. A third example of variation in the written language that appears to be first and foremost the result of different writing conventions concerns the use of final $-e$ in the first and third person singular of strong verbs as in ich sahe 'I saw' and er sahe 'he saw' (Elspaß 2005: 345-348). Again, there is no reason to assume that this ending represents dialect interference, while it had also virtually disappeared from printed texts by the nineteenth century (Elspaß 2014).

The examples demonstrate that the attested regional variation and regional writing practices can only partly be explained with reference to local or regional spoken varieties. Forms were used in writing that did not comply with contemporary prescriptions, but that were also not immediately linked to the writers' spoken vernacular. They are, in other words, intermediate forms indicative of a diaglossic repertoire.

So far, I have focused on regional variation as geography plays an important role in Auer's characteristics of the standard language (see Auer 2005, 2011). There is also a wealth of research on social variation in the past. Obviously, the existence of social variation is a complicating factor, diminishing the feasibility of the concept of a standard language when talking about European language history - all the more so when the standard is thought of as free from variation.

Adopting the broad social categories from the variationist tradition, such as rank, age and gender, research into social variation in the past has demonstrated significant differences between men and women, and between various social groups in terms of access to socio-economic resources. Extensive analyses, for example, have been carried out by Nevalainen \& Raumolin-Brunberg (2003) with regard to fifteenth-, sixteenth- and seventeenth-century English, and by Rutten \& van der Wal (2014) with regard to seventeenth- and eighteenth-century Dutch. Nevalainen \& Raumolin-Brunberg (2003: 110-132) investigate gender effects on fourteen changes 
in the history of English. Eight changes were led by female writers, among which the replacement of subject ye by you in the sixteenth century, the replacement of the possessive determiners mine and thine by my and thy in the sixteenth and seventeenth centuries, and the replacement of -th by $-s$ in the third person singular in the sixteenth and seventeenth centuries. The results show that women often led processes of language change in the past, too, particularly when the changes emerged from below the level of social awareness (Nevalainen \& Raumolin-Brunberg 2003: 131).

Different social groups adopted different sets of norms, testifying to a sociolinguistic repertoire that is more complex than dialect/standard diglossia. Turning to register variation, it becomes clear that intra-writer variation is yet another complicating factor. The notion of register adopted here corresponds to that of Biber \& Conrad (2009: 4-11), who stress the importance of the situational context for the choice of linguistic variants. So far, my examples were mainly morphological and phonological. It is, however, often assumed that standardisation begins with spelling convergence. The relatively uniform (but see below, Section 3.3) spelling practices in print language should not lead us to think that there was a uniform orthographical code in general use in the Late Modern period. Osselton (1984: 125) already drew attention to the "dual standard of spelling", one public, one private, found in the writings of eighteenth-century men of letters such as $\mathrm{Dr}$ Johnson, Addison, Pope and Swift, who all adhered to a similar system in their public writings, while employing another system in their private letters. Osselton (1984: 129) remarks that "traditional accounts of how English spelling developed historically have focused on the rise of one standard, not a variety of standards". In more recent years, numerous studies have confirmed the variability of the language of eighteenth-century elites, in orthographical practices but also in the fields of morphology and morphosyntax. Three examples are Sairio (2009), Fens-de Zeeuw (2011) and Henstra (2014). Interestingly, Fens-de Zeeuw (2011) focuses on Lindley Murray, a well-known eighteenth-century grammarian who in his writings did not always follow the strictures laid down in his own grammar. Despite the image of the eighteenth century as the age in which English was normalised, made uniform and codified, these studies show that this idea cannot be maintained. Even Robert Lowth himself, the alleged icon of English prescriptivism, did not adhere to his own rules of grammar in his private writings (Tieken-Boon van Ostade 2011: 183-184). The evidence presented in these and similar studies shows that there were situational constraints on the choice of variants, depending on the medium (letter vs published work), the audience (private vs public) or the social relationship between writer and addressee (cf. Nevalainen \& Raumolin-Brunberg 2003: 189-200; Nevala 2004). 


\subsection{Dutch diaglossia}

The case studies summarised in Section 3.3 indicate that the varietal spectrum that Early and Late Modern German and English writers had at their disposal can be characterised as diaglossic. For the Dutch situation, a similar argument can be built up. In this section, I will present a few case studies, largely building on Nobels (2013), Simons (2013) and Rutten \& van der Wal (2014).

Nobels (2013: 163) discusses the ending of first-person singular indicative verb forms in seventeenth-century Dutch, using a large corpus of private letters dating back to the 1660s/1670s, the Letters as Loot Corpus (see brievenalsbuit.inl.nl). In Middle Dutch, first-person singular indicative endings were generally characterised by schwa as in ik neeme 'I take', which gradually gave way to a zero ending ( $i k$ neem). In the seventeenth century, this change was in full swing. The incoming variant is dominant with c. $70 \%$ zero forms in both the northern and the southern parts of the province of Holland, in towns and cities such as Amsterdam and Rotterdam. In the Zeeland area, however, which borders on the southern parts of Holland, the pattern is reversed and final schwa is retained in c. $70 \%$, testifying to completely different writing conventions. There is an obvious link with the spoken language, since Zeeland and the south-west of the Dutch language area generally tend to retain final schwa in many positions up to the present day, but what is at stake here is that the written language in this period displays massive geographical variability when it comes to verbal inflection.

Rutten \& van der Wal (2014), when discussing apocope of final schwa in first person singular present tense indicatives, i.e. the replacement of $i k$ neeme by $i k$ neem 'I take' in seventeenth- and eighteenth-century Dutch, demonstrate the variable effect of social rank and gender, depending on time and region. In seventeenth-century Amsterdam, for example, upper-class men were the most conservative writers and in fact the only social group preferring final schwa. Differences between social ranks were also established for the southern parts of South Holland, but not for the even more southern region of Zeeland, where the change was just taking off. In the eighteenth century, awareness of the ongoing change led ever larger groups to cling to the historic forms. Upper-middle-class writers, including women, now stuck to final schwa, too, both in Holland and in Zeeland. Meanwhile, upper-class men, particularly in Amsterdam, switched to schwa-less forms and suddenly became the most progressive group, adopting a new writing convention, and distinguishing themselves from the still conservative practices found in the upper-middle ranks.

Another example of regionally-bound variation in seventeenth-century Dutch concerns diminutive formation, where the broad historical development runs from velar forms in -ke (from -kijn) such as briefke 'small/short letter' to palatal forms 
such as briefje and briefie. In this process of palatalisation, which is sometimes assumed to have spread from the north to the south, suffixes such as -ge and -che (e.g. briefge, briefche) represent an intermediate stage (Marynissen 1998). Nobels (2013: 189-224) analyses diminutive forms in the Letters as Loot Corpus, discussing dozens of orthographically different diminutive suffixes (Nobels 2013: 193195). After the many variants have been categorised into groups of palatal, velar and intermediate forms, all regions for which she has sufficient data prove to display this extremely wide variety of forms, but also that palatal suffixes are dominant in the northern parts of Holland, while velar suffixes constitute the majority in Zeeland. The southern parts of Holland are the only area where the intermediate forms occur quite often, and are even dominant (Nobels 2013: 204).

An interesting example of intermediate, i.e. non-dialectal and non-standard, forms can also be found in eighteenth-century Dutch, viz. deletion of final $n$ in unaccentuated syllables in forms such as brieven [brivə] 'letters', wij lopen [weI lopə], gelopen [xəlopə] 'walked' (Simons \& Rutten 2014). Almost systematic deletion is characteristic of the spoken language in large parts of the language area, including Holland, as well as in present-day standard Dutch. Final $<\mathrm{n}>$ is prescribed in standard orthography, and has always been part of writing conventions throughout the language area. Both in the southwest and the northeast, however, little or no deletion occurs in the present-day spoken language. When investigating final $n$ in the eighteenth-century part of the Letters as Loot Corpus, which comprises private letters from the 1770s/1780s, Simons \& Rutten (2014) found that letters from the northeast did contain the least instances of deletion, viz. 21\% (as opposed to $30 \%$ in Holland). But $21 \%$ deletion is quite surprising considering that fact that deletion is virtually absent from the spoken language today, especially against the background of the strong tradition of spelling final $n$. Again, we are dealing with a 'non-standard' phenomenon which cannot, however, simply be explained with reference to dialect interference. The case is similar to the German examples taken from Elspaß $(2005,2014)$. There appears to be a supralocal writing convention that is neither in line with the current standard nor with the local vernacular: it represents an intermediate stage and points to a diaglossic repertoire.

Vandenbussche (2004), Vosters \& Vandenbussche (2012) and Vosters et al. (2014) show that there was also considerable variation in southern Dutch writings from the early nineteenth century, which can partly be explained with reference to geography. Interestingly, their data comprise administrative and legal documents. The persistence of regional variation, even in the official domain, raises questions about the feasibility of diglossia to describe the sociolinguistic repertoire. With so many regionally-conditioned intermediate variants at hand, diaglossia seems a more apt general description of the contemporary varietal spectrum. 


\subsection{Supralocalisation}

In line with the results presented above, Rutten \& van der Wal (2014: 406) argue that what we find in historical documents representing the so-called Sprache der Nähe or language of immediacy (Koch \& Oesterreicher 1985) is neither transliterated local dialect nor the supposed standard of the time. Instead, it is an informal written language located somewhere in between these two poles of the varietal spectrum. The specific choice of variants, and their relative proximity to either the spoken base dialect or the written standard depends on situational, regional and social constraints, generating a considerable amount of inter- and intra-speaker/writer variation (Rutten 2016b). Based on their study of seventeenthand eighteenth-century Dutch private letters, Rutten \& van der Wal (2014) also show that the variants preferred by individual writers are not necessarily linked to their base dialect. Instead, many variants are used outside their region of origin, which is referred to as supralocalisation. Furthermore, supralocally used variants are not necessarily identical to the supposedly contemporary standard variants. As argued in the previous sections, there were multiple and sometimes divergent writing practices, some of which converged to or were identical with the supposed standard, while others were not. This means that Early and Late Modern communities exhibited diaglossia to the extent that intermediate variants, located between the base dialect and the supposed standard, abound.

The notion of supralocalisation goes back to earlier work such as Milroy, Milroy \& Hartley (1994), where it is argued in the context of present-day English that "linguistic variables operate at different levels of generality in terms of their territorial spread” (1994: 2). Some variants are highly localised, others characterise a somewhat wider region, while yet others have an even wider spread, creating a broad opposition of northern and southern British English, and a further group occurs in the whole English-speaking world. These observations are used to argue that we need to move beyond "the simplistic opposition between standard and non-standard" and that we should adopt "an approach that recognises gradations in terms of local and non-local” (Milroy, Milroy \& Hartley 1994: 2). The argument ties in with Auer's (2005) description of the development of regiolects and diaglossia in Europe today. Supraregionalisation as described by Hickey (2012) essentially refers to the same phenomenon of varieties of a language losing certain localisable features and becoming less regionally bound. Drawing on studies such as Milroy, Milroy \& Hartley (1994), Nevalainen \& Tieken-Boon van Ostade (2006: 288) describe supralocalisation as "an umbrella term to refer to the geographical diffusion of linguistic features beyond their region of origin" in the history of English. Whereas diaglossia and diaglossic repertoire are general descriptions of the sociolinguistic 
situation at a given place and time, supralocalisation centres around the trajectory of individual linguistic forms.

The shift away from the local and the localisable as implied in the concept of supralocalisation raises the question of its relationship to standardisation. Nevalainen \& Tieken-Boon van Ostade (2006: 288) argue that "standardisation is often facilitated by the prior development of suitable supralocal norms, being as it were, superimposed upon them". Similarly, Joseph (1987) distinguishes between language standards and standard languages, where the former refers to the multiple and sometimes conflicting supralocal norms for writing developed in European language histories from the earliest days onward, and the latter to the more or less uniform standard languages of the present. One of the most important research goals in standardisation studies, Deumert \& Vandenbussche (2003: 456) argue, is to clear up the interaction between "pre-existing language standards and the emerging standard language". Standardisation, then, is generally preceded by a period of multiple and variable norms for writing, that is, by co-existing instances of supralocalisation. Such a shift away from strictly local features is not necessarily a shift towards uniformity (Milroy, Milroy \& Hartley 1994; Hickey 2012). Supralocalisation does not necessarily imply standardisation. This is clear from some of the examples presented in the previous section, where it was argued that there were writing conventions that were neither localisable nor in line with the contemporary standard. Nevalainen \& Raumolin-Brunberg (2003: 183), who investigated processes of supralocalisation in English texts dating back to the fifteenth, sixteenth and seventeenth centuries, conclude that "supralocalizing features do not have any single path of transmission ... it is individual linguistic features rather than fully-fledged varieties that get selected, accepted and diffused across the country" [emphasis in the original]. While writers may have an idea about the standard, or at least about a preferred form for writing at the level of individual variables, this idea is not necessarily similar for all of them nor is it analogous to the supposedly standard language of the time. Various instances of supralocalisation may coexist, with or without one of these being promoted to the standard form.

Closely related to supralocalisation is another relevant notion from the historical sociolinguistic literature, viz. intended supralocal variety. The notion of an intended supralocal variety was developed in German historical sociolinguistics (intendiertes Hochdeutsch, cf. Mihm 1998) and "is used to refer to a variety which does not meet the formal requirements of a standard language (e.g. consequent spelling and grammatical soundness), but which is nevertheless intended by the writer to fulfil the functions attributed to a standard variety (e.g. supra-regional communication, prestige variety). The term refers, accordingly, to the functional value of a variety in the eyes of the writer and cannot be defined in fixed formal 
terms" (Vandenbussche 2004: 30-31; cf. Rutten \& van der Wal 2014: 74, 406). The crucial distinction here is that between form and function. Whereas standardisation is often referred to as minimal variation - or the striving for minimal variation - in form, the concept of an intended supralocal variety is restricted to the functional side. Language users adopt forms that are meant to function supraregionally. The concept of an intended supralocal variety is essentially a negative one. Language users do not aim to use the one standardised or prescribed form, if there is such a form. Instead, they render their language less localisable by adopting less-localisable forms, but these can be of any kind - as long as they are less localisable. By implication, writers do not usually aim to produce transliterated dialect. "As a matter of fact," Vandenbussche (2004: 21) adds, "the formal character of this 'intended standard language' will be different for each writer since it is the highest variety mastered on his personal continuum between dialect and standard language". Again, this means that we have to reckon with multiple and variable moments of de-localisation, and that the norms developed in usage need not be uniform, but are just not localisable.

The notion of an intended supralocal variety constitutes the writer-oriented and functional side of supralocalisation, which is primarily focused on the trajectory of the linguistic forms themselves. At the level of the community's sociolinguistic repertoire, the Early and Late Modern period can be called diaglossic, because linguistic variants exhibited different levels of supralocalisation, and because writers did not always adopt the same set of norms, although most of them aimed at de-localisation. The issue of norms is continued in the next section.

\subsection{Codifications and audiences}

In the context of the present book, the relation between supralocalisation and standardisation in a situation of societal diaglossia needs to be explored even further. In this section, I will argue that in addition to the aforementioned plurality of conventions for writing, the standard language norms themselves were characterised by considerable heterogeneity.

Codification is perhaps one of the most conspicuous aspects of the sociolinguistic situation in post-Medieval Europe. From the fifteenth century onwards, spelling guides, schoolbooks, grammars and dictionaries of vernacular languages began to appear. Such publications, which were followed by other grammar books in subsequent centuries, are often considered milestones in the standardisation of the languages in question.

A first crucial observation - perhaps a commonplace but all too often easily passed over - is that the norms and prescriptions laid down in orthographies 
and grammar books were usually far from uniform (e.g. Poplack et al. 2015). Grammarians and other language commentators proposed different systems of prescription, with these varying prescriptions often in competition with each other, and where prescriptions are in competition, there can be no consensus about what is right and what is wrong. When Auer (2005: 8) remarks that the standard language in this period is subject to "some codification" this is an appropriate observation in the sense that efforts at codification characterise the Early and Late Modern period, as long as it is understood that these efforts were multiple and diverse, and moreover that they changed over time. Codifications is the most suitable term when talking about the sixteenth and early seventeenth century. But also later on, when there is often more agreement among grammarians, normative diversity still prevails. Langer (2014), for example, discusses stigmatisation in eighteenth-century German, while indicating the variability of some of the most stigmatised features, such as the diminutive suffix. There was competition between -chen and -lein in the written code, with -lein gradually becoming stigmatised as regional (Southern) and/or outdated. Towards the end of the eighteenth century, however, Adelung, one of the well-known proponents of normative grammar, in his Deutsche Sprachlehre (1782) still preferred -lein in specific registers. An interesting example is also Schottelius, the famous codifier of seventeenth-century German, who did not comment on the acceptability of polynegation and even listed examples such as mit nichten nicht as emphatic negations, while nevertheless eliminating a handful of polynegations in more recent editions of his grammar (McLelland 2014).

As noted above (Section 3.3), grammarians, including notorious prescriptivists such as Lowth and Murray in eighteenth-century England, did not always follow their own prescriptions. Apart from that, grammarians sometimes dealt with variation by relegating the variants to different styles, adopting this concept from the rhetorical tradition. Lowth, for example, in his Short introduction to English grammar (1762) distinguished between different styles of speech and writing, which are characterised by different linguistic requirements. Preposition stranding as in Horace is an author, whom I am much delighted with, a verb form such as has and the indicative were more suited to the so-called familiar style, whereas pied piping (viz. with whom instead of whom ... with), hath and the subjunctive were more appropriate to the solemn and elevated style (Tieken-Boon van Ostade 2011: 183-184). Such distinctions recall Osselton's remarks on the dual standard of spelling in eighteenth-century England (Section 3.3) and Adelung's preference for-lein-diminutives in specific registers.

In the Dutch language area, Lambert ten Kate is well-known for his analysis of variation in terms of so-called stylistic differences. In his 1723 Aenleiding tot de kennisse van het verhevene deel der Nederduitsche sprake ('Introduction to the knowledge of the sublime part of the Dutch language'), he adopted the familiar, 
polite and elevated style from the rhetorical tradition. He then distributed grammatical variants over these stylistic levels. In the case of nominal inflection, for example, at a time when spoken Dutch was characterised by the almost complete loss of inflectional endings, he prescribed synthetic case endings in the elevated style and periphrastic constructions with prepositional phrases in the familiar style. The polite style took a middle position, often siding however with the familiar style (Rutten 2012). This kind of sensitivity to differences between styles or registers, which implies varying norms depending on situational conditions, is not often seen as a crucial part of eighteenth-century metalanguage. In many European language areas, the period is often cast in terms of increasing uniformity and normativity, and of intensified codification and prescription (cf. the chapters in Rutten, Vosters \& Vandenbussche 2014). Nonetheless, we have to reckon with multiple codifications, and with the context-dependency of notions of right and wrong. Also from the perspective of codification, therefore, the multiplicity and variability of norms evidence diaglossia rather than diglossia.

The context dependency of codifications can even be taken a step further. Nevalainen (2014), discussing language norms in seventeenth-century England, notes that we need to think about language norms in terms of their target groups. In the seventeenth century, these were often quite restricted, with English grammars being targeted towards either foreigners, typically merchants, or schoolboys, on the assumption that the acquisition of Latin would be easier when grammatical terms and concepts had first been learnt via English. It is only with the rise of the middle classes in the eighteenth century that a new ideology came into being, at the core of which lies the idea that upward social mobility depends on language skills, i.e. on the ability to use the 'standard' (Beal 2004). Moreover, this new middle class was subsequently ready to accept all the social prejudices inherent in a unified, exclusive standard (Hickey 2010). Increasingly, standard language norms became essential and defining factors in the creation (or appropriation) of a specific social and educated identity. The new genre of the usage guide resulted from this development (Tieken-Boon van Ostade 2014).

Langer (2014) points to a similar development in eighteenth-century Germany, where a social split arose between those with access to supraregional High German and those without, which distinguished the lower classes on the one hand, and the middle and upper classes on the other. A widening of the target audience of metalinguistic discourse can also be discerned in the history of Dutch (Rutten 2012). The decisive turning point can be located in the second half of the eighteenth century, when the literary and elitist orientation of the earlier decades of the century was abandoned in favour of an inclusive approach to language, underpinned by a nationalist ideology. 
What is crucial in Late Modern Dutch, English, French and German (cf. Rutten, Vosters \& Vandenbussche 2014) is that the target audience of metalinguistic publications changed from identifiable groups such as socio-cultural elites into the nation as a whole. Normalised language changed from a tool for specific situational purposes into a central issue of education for the entire population. At the same time, language planning changed from one out of many socio-cultural occupations into a core element of the socio-political construction of national identities. As Burke (2004: 166) comments, language underwent "nationalization". Efforts at codification, in other words, should be interpreted socially, taking into account the target audience of linguistic prescriptions and proscriptions. In many language areas, it is only from the late eighteenth century onwards, with the advent of the modern nation states, that adherence to a defined and uniform set of standardised norms is expected from all language users, and that such a set of norms is therefore taught in schools. What is being codified in earlier publications is often only a specific variety for special purposes, to be used only by certain language users in specific contexts. This means that it is questionable to what extent such a variety can be considered 'the roof' of a collection of genetically related spoken and written varieties.

Finally, new ways of analysing the traditions of codification and prescriptivism have come into being. As argued a.o. by Lodge (2013) and Ayres-Bennett (2014) with regard to seventeenth-century French, there is a need to move away from the view that linguistic commentators such as the remarqueurs were strictly prescribing the forms that language users should adopt, or that they were linguistic legislators. Both Lodge (2013) and Ayres-Bennett (2014) suggest that the remarqueurs were often merely reflecting usage, and that they were keen observers of changing usage. They interpret the metalinguistic position taken by Vaugelas and others within a sociohistorical framework of urbanisation and social mobility, where the plurality of linguistic forms found in interaction is dealt with through the attachment of social values to particular forms. The remarqueurs observed and recorded such processes of value attachment. The implication is that a top-down view of the linguistic situation, with prescriptivists prescribing the forms that language users should adopt, does not offer an accurate description of the sociolinguistic space in history. Language norms were not developed on the one side and then transmitted to the other side. Instead, normative works were part of the same field where language users as well as language observers engaged in norm negotiations. As such, the call for a more nuanced and much richer description of the sociolinguistic situation resembles Milroy's (1992: 147) argument against "a conceptualisation of sociolinguistic space that is unidimensional - a space in which the elite groups set the tone in language, dress and other cultural matters, and in which lower groups strive to imitate their lead". For Milroy, the core of the argument is that language users often 
do not follow the elite variety, and that linguistic changes often do not originate in the alleged prestige variety. From the elite perspective, however, a similar line of reasoning criticising the unidimensional prestige model applies, in that language commentators were not always involved in a simple act of prescription, but were taking stock of the various linguistic forms that were around and the social values connected to them. Therefore, Early and Late Modern dialect/standard constellations were not just diaglossic rather than diglossic because of the multiple and variable norms for writing attested in usage, but also because normative discourse itself was varied and variable.

\subsection{Final remarks: From diaglossia to diglossia}

In post-Medieval western Europe, geographical, social and register variations persist in the written language as shown by research on Dutch, German and English. Similar arguments have been put forward in studies of Danish, French, Finnish, Irish, Lithuanian, Scottish, etc. (see, among others, Meurman-Solin 2000; Martineau 2007; Nordlund 2007; Sandersen 2007; McCafferty \& Amador Moreno 2012; Klippi 2013; Tamošiūnaite 2013). The standardisation model proposed in Nevalainen \& Tieken-Boon van Ostade (2006) states that standardisation is preceded by supralocalisation. It should be stressed that a plurality of supralocalising forms is not just an apt description of the Middle English, Middle Dutch, Middle High German etc. periods. The multiple and flexible normative points of orientation characteristic of supralocalisation extend well into the modern period, and help explain patterns of variation in the seventeenth and eighteenth centuries, and building on Elspaß (2005), Fairman (2007a, 2007b), McColl Millar (2012), Auer (2014) and others, also in the nineteenth century. In sum, the variation found in historical sources cannot always be explained away by referring to the gradual implementation of the standard language.

Firstly, there were regional writing practices, some of which were opposite to what is usually considered standard. This means that also for post-Medieval times, we have to reckon with various instances of supralocalisation, and that the prototypically Medieval phenomenon of regional variation in the written languages existed well into modern times. As a consequence, it is unclear to what extent the supposed standard of the time was regarded as such by language users in the past.

Secondly, prescriptivists did not always agree on the preferred prescriptions and proscriptions. Moreover, normative publications were not always targeted towards the general public. The social reach of language norms was often fairly limited up until the second half of the eighteenth century, and it has been argued that the 
sociolinguistic space was more complex than simply one-way traffic from prescription to usage. In fact, the effects of prescriptivism are still quite uncertain, and there is not much evidence of clearly defined influence across the board (Rutten, Vosters \& Vandenbussche 2014).

This means that it is uncertain to what extent the criteria for standard languages as developed in Auer $(2005,2011)$ are applicable to the history of European languages. Instead, diaglossia as developed in Auer $(2005,2011)$ is a very useful concept to describe the varietal spectrum available to language users at a given place and time, and should be applied to language history as much as to present-day situations. Related concepts from the historical sociolinguistic research tradition are supralocalisation and intended supralocal variety, where the first refers to the course of individual variants, while the second addresses the functional aims of language users. What is crucial on the observational level is that history provides us with numerous documents set in a language that is neither dialectal nor standard, a language that could therefore be characterised as intermediate, signaling a diaglossic repertoire.

Diaglossia is the keyword when describing not just sociolinguistic situations in Europe in the present, but also when looking back on the twentieth, nineteenth, eighteenth, and earlier centuries. In fact, Nevalainen (2012) argues that the rise of an English standard-like spelling between 1400 and 1600 began with various supralocal varieties, a situation that she describes as diaglossic, which only later gave way to diglossia in the sense of a single endoglossic spelling standard roofing the spoken dialects. This means that diaglossia should be extended even further back in time. If these historical periods were indeed diaglossic, the question of the interaction between supralocalised forms and/or varieties and general standard languages becomes all the more pressing. Has diaglossia ever given way to a situation with a well-defined and codified standard language? The position taken here is that the actual sociolinguistic situation of diaglossia was provided with an extra layer, viz. the ideological layer of diglossia.

To appreciate this, it is important to acknowledge that diaglossia and supralocalisation on the one hand, and standardisation on the other, are concepts of a very different kind. Supralocalisation refers to the use of specific variants outside their region of origin. Diaglossia refers to community repertoires with variants or bundles of variants that are neither strictly dialectal nor standard. As such, supralocalisation and diaglossia are generalisations over empirical and quantifiable results. Standardisation, on the contrary, is an ideology, and a standard language is "an idea in the mind rather than a reality" (Milroy \& Milroy 2012: 19). While the Milroys argued for this ideological view of standardisation in the context of the present-day spoken language, where "a good deal of variety is tolerated in practice" (2012: 18), 
the evidence presented here suggests that the written language of the past was also not so "fixed and invariant" that it can "properly be called the standard language" (2012: 18). This means that diaglossia may be the best description of the linguistic situation in post-Medieval times, which has given way to an ideal of standardisation without, however, losing its empirical applicability. When exactly the ideal of a uniform standard language used and understood by all members of a specific community came about is an empirical question. I argue that the second half of the eighteenth century was a crucial phase. It is in this period that Dutch developed into a symbolic marker of the newly formed Dutch nation state.

As a consequence, the typological and historical development from diglossia to diaglossia (Auer 2005, 2011) should be turned upside down (Nevalainen 2012). Diaglossia is the historical state of the written language, which became ideologically accompanied and/or replaced by diglossia, more specifically, by the ideal of a uniform standard language that reduces all other variants and varieties to non-standardness. Watts (2011: 232), analysing the British situation in the eighteenth century, observes a similar "bipartite division of language in Britain" into polite or legitimate language on the one hand, and vulgar language on the other. It is this split of the varietal spectrum into standard and non-standard that constitutes the major metalinguistic change of the eighteenth century, resulting in the Dutch national language policy in the first decade of the nineteenth century. 


\section{CHAPTER 4}

\section{Metalinguistic space}

\subsection{Introduction}

Chapter 2 discussed the rise of linguistic nationalism in the second half of the eighteenth century, and the concomitant discourse about the need to teach the national language in schools. Language became an object of political control, and laws were passed to ensure that the 'mother tongue' was spread over the members of the national population. Chapter 3 described the sociolinguistic situation that the newly developed planning initiatives were targeted at as diaglossic. The discursive construction of a supralocal variety of written Dutch as the language of the Dutch nation involved the establishment of a standard language culture with one codified standard language, and the simultaneous demotion of other varieties to non-standardness. This means that the sociolinguistic space was ideologically reconceptualised as diglossic. In the present chapter, I will concentrate on one aspect of the sociolinguistic space, viz. metalanguage. In particular, I will discuss changes in normative grammar in the eighteenth century and in the early nineteenth century that eventually resulted in the official spelling and grammar of 1804 and 1805. These changes mirror the general trends described in Chapters 2 and 3.

Section 4.2 introduces three stages in Dutch normative grammar from the early eighteenth century to the early nineteenth century. I will refer to these stages as elitist, roughly the first half of the eighteenth century, 'civil', from c. 1740 onwards, and finally national from the 1770s onwards into the nineteenth century, and beyond. The first and second stages are discussed in Section 4.2 and 4.3, and the transition towards the third stage in Section 4.4. In Section 4.5, I present a detailed study of one specific aspect of Dutch grammar that has attracted a lot of normative attention since the sixteenth century, viz. nominal inflection, demonstrating how the attested changes in grammar-writing affect prescription, particularly with regard to case.

\subsection{The three stages of normative grammar}

In the first half of the eighteenth century, language planning activities were quite restricted and focused regarding their target audience and target registers or varieties. Towards the end of the century, metalinguistic discourse was reconceptualised 
in nationalist terms, resulting in the official language policy at the beginning of the nineteenth century. Noordegraaf (2004a) and van de Bilt (2009: 60-68) call one of the defining characteristics of eighteenth-century metalinguistic discourse its social orientation. Many early-eighteenth-century works, Noordegraaf (2004a: 218) says, have "a social view of language", while "the linguists of the next generation took a step further. To them, the mother tongue also became a means to establish a community, a nation, and to improve civil society. Language is therefore seen as a socialising force". This change of orientation from restricted to social, and then to socialising is elaborated upon in Rutten (2009), where three stages are distinguished in the development of eighteenth-century metalinguistic discourse, viz. elitist, 'civil' and national. With respect to target audiences and target registers, the discursive change can also be conceptualised as running from exclusive to inclusive. This does not mean that grammarians increasingly adopt an inclusive approach to the input register, incorporating, for example, regional variants (see also Chapter 7). On the contrary, the descriptive apparatus as well as the prescriptions and proscriptions remained remarkably stable from the early eighteenth century to the early nineteenth century.

The restricted approach characterising the first decades of the eighteenth century means that grammar-writing can be thought of as an elitist activity, often conducted by upper and upper-middle class men such as poets and ministers, and also aimed at their immediate peers (Rutten 2006, 2007). There were strong social, situational and register conditions on the use of Dutch in accordance with the supposed rules of grammar. Knowledge of the body of rules laid down in normative grammar was deemed necessary particularly for literary authors and orators, but irrelevant for other purposes. The period is also characterised by its so-called Vondelianism, i.e. by a preference for written language norms founded on the language of literary authors, most prominently of the poet Vondel (Rutten 2006). The period brought forth important normative grammars such as Arnold Moonen's Nederduitsche spraekkunst ('Dutch grammar', 1706; Schaars 1988) and Willem Séwel's Nederduytsche spraakkonst ('Dutch grammar', 1708, 21712). Another important work is Huydecoper's Proeve van taal-en dichtkunde ('Essay on the study of language and poetry', 1730), an extensive collection of linguistic and poetical remarks to one of the works of Vondel (de Bonth 1998).

One particular and somewhat narrow interpretation by the poet and Latin school teacher David van Hoogstraten (Rutten 2006), who mainly wrote about the gender of nouns and nominal inflection, even defines the intended readership as especially male juveniles who are to become the next great poets. In such cases, grammar serves literature. Here, grammar has a propaedeutical function in the education of a cultural elite. In this period, grammar also functions as a mark 
of intellectualism, and of scholarship. Studying the grammar of Dutch is hardly possible without knowledge of Latin and/or Greek, and it would be only slightly exaggerated to call Moonen's (1706) grammar of Dutch a Latin grammar in which the object language has been substituted by Dutch. Linguistics, in other words, was primarily a scholarly occupation, carried out by well-educated and multilingual members of the international Republic of Letters (Rutten 2007). The few linguistic works that do not focus on literary authors and orators are written in Latin such as Adriaen Verwer's Linguae belgicae idea grammatica, poetica, rhetorica (1707; van de Bilt 2009) or otherwise clearly aimed at a learned public, such as ten Kate's complicated and voluminous Aenleiding ('Introduction', 1723).

Around the middle of the century, grammarians argue that explicit knowledge of the grammar of the supralocal variety should be extended to other parts of society, and that ideally, all members of the population should be aware of these rules, abandoning the fairly restricted target audience and target varieties of the earlier decades. From c. 1740 to 1770 , the intended readership of normative grammar was enlarged by incorporating men as well as women, and the youth of the upper as well as the middle ranks. Knowledge of the grammar of Dutch came to serve as a mark of civilised burghers 'citizens' (Crowley 1996: 73). In this period of so-called 'civil' grammar, linguistic publications from the elitist period are rephrased in a less classical vocabulary, and educational strategies are employed to render grammatical knowledge more comprehensible to larger parts of the population.

The period of national grammar runs from about 1770 into the nineteenth century and beyond, and is characterised by a further extension of the intended readership. Normative grammar now becomes a matter of national concern (Noordegraaf 2004a). 'Civilised', 'educated' language is no longer only a mark of respectable citizens. It should be the hallmark of society as a whole and therefore be taught in schools. The Nederduitsche Spraekkunst, voor de Jeugdt 'Dutch grammar, for the young' (1769) by Kornelis van der Palm marks the transition from 'civil' to national grammar. It presents received knowledge of the previous periods in a simplified and refined manner. It is explicitly meant for use in schools. At the beginning of the nineteenth century, the development from elitist to national grammar results in the official language policy, specifically in the national orthography (Siegenbeek 1804a) and grammar (Weiland 1805a), imposed by the government and to be used by the administration and in the educational system. This beginning of the official codification of Dutch was initiated by the minister of national education (see Chapter 1), i.e. Johan Hendrik van der Palm, Kornelis's son. 


\subsection{From elitist to 'civil' grammar}

The period of elitist grammar brought forth a series of works on language that laid the foundation for the rest of the century. Spelling made up an important part of the grammatical work of Petrus Francius (1699, Dibbets 1995). Gender and nominal case were central to the works of van Hoogstraten published between 1700 and 1723 (Rutten 2006). Minister Jacobus Nylöe published a comprehensive overview of orthographical, morphological and stylistic norms (1703, see Schaars \& te Wilt 1989). Full grammars were written by Moonen (1706), Séwel $(1708,21712)$ and Verwer (1707). A range of orthographical, morphological and syntactic topics were discussed by ten Kate (1723) and Huydecoper (1730). Thus, the first decades of the eighteenth century constituted a highly productive metalinguistic period, after a relatively quiet interlude in the second half of the seventeenth century, during which not many linguistic publications came out.

A significant development that began in the final decades of the seventeenth century is the establishment of widely shared and acknowledged normative points of orientation (Dibbets 2003a). Whereas complete consensus was not reached, and debates about the normative value of specific sources continued into the eighteenth century (Rutten 2006), it is safe to say that from c. 1700 onwards, the first half of the seventeenth century was considered a period of exceptional cultural and linguistic glory (see also Chapter 5). Of the many texts produced in this period, a handful were perceived as examples of the Dutch language in a state of near-perfection, viz. the works of the literary authors Hooft and Vondel, and the official Bible translation of 1637. Some language observers historicised this state of near-perfection by arguing that its superiority was at least partially due to its resemblances to the original state of the language as found in Medieval sources (Rutten 2006: 84-92). The period in between, i.e. the fourteenth, fifteenth and sixteenth centuries, were usually considered degenerate under the influence of foreign domination and contact with Romance varieties (see Chapters 7 and 8). The establishment of a normative canon, dominated by Vondel (hence: Vondelianism), implied that the rules of Dutch grammar constructed in the elitist period strongly depended on the written literary language produced in the western parts of the language area in a long gone era. This body of rules, however, was to be the main point of reference in the following century.

A key characteristic of the next period of 'civil' grammar is the effort to simplify the norms laid down in the first period in order to reach a wider audience. Important texts from this period are van Belle (1748, 1755), Elzevier (1761) and de Haes (1764). The Nederduitsche spraekkunst ('Dutch grammar') by de Haes was published posthumously in 1764 , added to a collection of poems, but already 
conceived around 1740 (Dibbets 2003b: 213). The manuscript had circulated among members of the Rotterdam-based literary society Nature et Arte. Dibbets (2003b: 193-222) shows de Haes's strong dependence on Moonen (1706), Séwel (1712) and Huydecoper (1730), and also mentions Elzevier's dependence on de Haes. Elzevier, too, was a member of Natura et Arte, and his Proef van een nieuwe Nederduitsche spraekkonst ('Outline of a new Dutch grammar') was also added to a collection of poems. The rise of literary and scientific societies is typical of particularly the second half of the eighteenth century, and is usually associated with the rise of the bourgeoisie, and with the public domain being taken over by larger parts of society (Kloek \& Mijnhardt 2000). The eighteenth-century phenomenon of sociability (Singeling 1996) enabled the upper as well as the middle ranks of society to establish networks in order to share and concentrate power and knowledge. In the Dutch context, these societies were usually involved in the educational Enlightenment project aimed at the dissemination of knowledge and culture, science and the arts, over increasingly larger parts of society (de Vries 2001).

The simplification aimed at by de Haes and Elzevier is not just obvious from the size of their works. Moonen (1706) and Séwel (1712) cover several hundreds of pages, whereas de Haes' grammar is 170 pages, and Elzevier's outline only 90 . In what follows, I will give a few examples of the way in which de Haes and Elzevier tried to render the grammar of Dutch more accessible to larger parts of the population (cf. Rutten 2009). I will then turn to van Belle.

A first example is terminology. In the Dutch grammatical tradition, the nominal cases were sometimes referred to by their Latin names (nominativus, genitivus etc) or with Dutchified alternatives (nominatief, genitief etc). The Latin terms could also be replaced by numerical references, i.e. the first case, the second case etc. Translations had already been offered in the first full grammar of Dutch, the Twe-spraack ('Dialogue', 1584), and these translations lasted well into the eighteenth century (Rutten 2006: 2401-241); see Table 1.

Table 1. Dutch terms (normalised spelling) for Latin case names as introduced by the Twe-spraack 'Dialogue' (1584)

\begin{tabular}{llll}
\hline Latin term & Dutch term & Origin & English gloss \\
\hline nominativus & noemer & $<$ noemen 'name, call' & namer, caller \\
genitivus & barer & $<$ baren 'bear' & bearer \\
& teler & $<$ telen 'grow' & grower \\
dativus & gever & $<$ geven 'give' & giver \\
accusativus & aanklager & $<$ aanklager 'accuse' & accuser \\
vocativus & roeper & $<$ roepen 'call' & caller \\
ablativus & $($ af)nemer & $<($ af)nemen 'take (away)' & taker \\
\hline
\end{tabular}


The Dutch terms were modeled after the Latin originals. The term barer for genitive was commonly replaced by teler from Moonen (1706) onwards.

By 1700, the Dutch terms had become part of standard grammatical terminology, but they were also subject to severe criticism (de Haes 1764: 19). Note that the Dutch terms are as intuitive to Dutch speakers as the English glosses are to speakers of English, i.e. hardly at all. The criticism concerned the fact that all cases were conceptualised as agentive, for example, the noun phrase that takes the vocative is not the person calling, so roeper 'caller' is incorrect. Instead, it is the person spoken to. Also, the semantic functions of the cases could be expressed much better by a different verb, for example, bear, grow and accuse are not the typical actions associated with genitive and accusative functions. Table 2 shows the new terms introduced by de Haes (1764), which were slightly modified and taken over by Elzevier as well as by van der Palm (1769, see Section 4.4).

Table 2. Dutch terms (normalised spelling) for Latin case names as introduced by de Haes (1764)

\begin{tabular}{lll}
\hline Latin term & Dutch term & English gloss \\
\hline nominativus & werkende persoon of zaak & working person or thing \\
genitivus & eigenaar of bezitter & owner or possessor \\
dativus & ontvanger & receiver \\
accusativus & daadlijk bewerkt wordende persoon of zaak & person or thing acted upon \\
vocativus & aangesprokene persoon of zaak & person or thing spoken to \\
ablativus & onbepaalde naamval & indefinite case \\
\hline
\end{tabular}

Elzevier (1761: 49-58) considered de Haes's terminological innovation to be so important that he devoted ten pages of his 90-page outline to the issue. In historical grammars, the ablative case is not distinguished for any period of Dutch, hence the half-hearted decision to keep the case, in line with the Latin model, yet to call it indefinite.

One of the reasons for Elzevier's enthusiasm about de Haes's new terminology was his desire to adopt a simplified approach to grammar as opposed to Moonen's thick book for the learned:

Vooraf zullen wy onderstellen, dat onze leerling geen vreemde talen verstaet, en dus ook niets van onze taelgronden weet; want iemand die de Latynsche, of één ander tael magtig is, zal de eigenschappen en gronden onzer tael gemakkelyk begrypen, en met vrucht de Spraekkonst van Monen doorbladeren; want die Heer schynt eer zyne Spraekkonst te hebben geschreven voor hun, die de tael reeds verstaen, dan voor Leerlingen die begerig zyn om hun eigen tael te leeren.

(Elzevier 1761: 50) 
Beforehand, we will assume that our student does not understand any foreign languages, and therefore also does not know anything about the rules of our language; for someone who masters Latin or another language will understand more easily the properties and rules of our language, and successfully thumb through the grammar by Moonen; since that gentleman appears to have written his grammar rather for those who already understand their language than for students who are eager to learn their own language.

After this introductory statement, which revealed Elzevier's aims and target audience, he discussed the six nominal cases and their names, relying entirely on Moonen (1706) and de Haes's manuscript grammar published in 1764.

Another example concerns the definition of the noun, where Elzevier (1761: 76) again explained that he aimed to offer a simplified account of Moonen (1706):

De Zelfstandige Naemwoorden die nu volgen, zullen wy eenvoudig verhandelen, zonder ons optehouden met de verdeeling die Monen daer van maekt, als dezelve onderscheidende in oorsprongkelyken, afgeleiden, eigen, enz. wy zullen kort gaen, en zeggen dat het een Zelfstandig Naemwoord is, dat alleen staende, het wezen eener zelfstandige zaek, die men noemt, volkomen betekent, als: man, vrouw, kind, vis, vogel, enz.

(Elzevier 1761: 76)

We will discuss the Nouns, which follow now, in a simple way without concerning ourselves with the divisions Moonen makes, dividing them into primitive, derived, proper etc. We will keep it short and say that a noun is that which by itself completely signifies the nature of a thing that is named, such as man, woman, child, fish, bird etc.

The definition is copied from Moonen (1706: 47). Similarly, Elzevier (1761: 96-104) used only nine pages to summarise Moonen's (1706: 138-234) extensive discussion of the verb, while indicating the usefulness of Moonen (1706) as a book of reference. Elzevier summarised, shortened and simplified Moonen's account of the verb in many ways, but he also elaborated on the discussion of the subjunctive, which he probably deemed necessary given the near-disappearance of the subjunctive in most post-Medieval registers of Dutch (Rutten 2009: 63).

In 1748 and 1755, van Belle, a schoolteacher in the city of Haarlem, published two books on the grammar of Dutch. Both publications have the adjective kort 'short' in the title. Van Belle (1748) has about a hundred pages, van Belle (1755) only 55. Van Belle's aim was to teach the citizens of Haarlem the grammar of Dutch, not just the elite but also the middle ranks of society, not just men but also women, and he hoped that all citizens would transmit their knowledge to the younger generations (van der Wal 1990; Rutten 2008a). In addition, his 1755 publication cuts grammar loose from the literary context characteristic of the period of elitist grammar and also present in the works of de Haes and Elzevier. For van Belle, knowledge of the grammar of Dutch was a matter of mature citizenship. 
To reach the largest audience possible, van Belle showed himself to be a real educational experimenter, moving well beyond de Haes's and Elzevier's efforts to simplify the received set of language norms, and using a wide variety of teaching methods including tables as well as visual and typographical aids (Rutten 2008a). A striking example from his 1748 book is the fact that it was written in rhyming verse, which would help learners memorise the rules of grammar. Another remarkable memory aid was his system to systematise and remember the conjugations of verbs (van der Wal 2002). He introduced nonce words and symbols to represent the principle parts of both weak verbs without vowel changes and the strong verbs classes with their varying types of ablaut (van Belle 1748: 39-40). The nonce words and the symbols comprise three components for the representation of the vowel quality, and a fourth component in case the participle ends in -en instead of a dental suffix; see Table $3 .^{1}$

Table 3. Dutch verb classes according to van Belle (1748)

\begin{tabular}{llll}
\hline Nonce word & Symbolic pattern & Dutch verb & English gloss \\
\hline panama & +++ & haat-haatte-gehaat & hate-hated-hated \\
panamalen & +++- & weven-weefde-geweeven & weave-wove-woven \\
panémé & $+\neq \neq$ & koop-kógt-gekógt & buy-bought-bought \\
panémélen & $+\neq \neq-$ & sluit-sloot-geslooten & close-closed-closed \\
panémalen & $+\neq+-$ & treed-trad-getreeden & tread-trod-trodden \\
panémielen & $+\neq \neq-$ & steel-stal-gestolen & steal-stole-stolen \\
\hline
\end{tabular}

Van Belle, however, did away with these teaching aids in 1755, and came up with completely different methods to systematise the various verb patterns, testifying to his ongoing efforts to render the rules of grammar as accessible as possible. He now used numerical indications to represent the principle parts $(1,2,3)$, letter strings to represent the ablaut types (aba, abb etc.), and capital letters to indicate the relevant vowels. A few examples are given in Table 4.

Moreover, he also added a folded sheet, three pages in size, to the grammar book, listing the conjugations of seventeen frequent verbs, marked with letters denoting the vowel pattern (abd etc).

Van Belle's educational ingenuity was remarkable (Rutten 2008a). Whereas Elzevier's and de Haes's approach mainly consisted of simplifying the thorough works of the earlier period, such as Moonen (1706), van Belle introduced various kinds of new teaching methods. The 1755 grammar was published posthumously.

1. In van Belle (1748: 39), the third symbol of the final line is identical to the second symbol, which has to be a mistake. Also, van Belle's examples do not represent all verb classes historically distinguished for Dutch (van der Wal 2002). 
Table 4. Examples of Dutch strong verbs (van Belle 1755)

\begin{tabular}{lcccl}
\hline \multicolumn{4}{c}{ Principle parts } \\
\hline Person & 1 & 2 & 3 & English gloss \\
\hline Ik & GEEf, & GAf, & GegEEven & I give, gave, given \\
\multirow{2}{*}{ Ik } & a. & b. & a. & \\
& ZOEk, & ZÓgt, & GezÓgt & I seek, sought, sought \\
Ik & a. & b. & b. & \\
& BrEEk, & BrAk, & GebrOken & I break, broke, broken \\
& a. & b. & d. & \\
\hline
\end{tabular}

In the introduction, the publisher referred to another grammar book by van Belle, still easier than the 1755 one, written in dialogue, i.e. in a format with a long tradition in the history of education. The book was never published. A few years later, the grammatical dialogue was reintroduced into the history of Dutch linguistics with the publication of van der Palm (1769).

\subsection{From 'civil' to national grammar}

The third period of national grammar continued the approach taken in the second period, but radicalised it. The aim to reach larger parts of the population than in the period of elitist grammar, as grammatical knowledge was an element of mature citizenship, was turned into an educational mission. If people had to learn grammar, they should be taught grammar in school. The Nederduitsche spraekkunst, voor de jeugdt ('Dutch grammar, for the young', 1769) by van der Palm marks the transition to the period of national grammar. Interestingly, van der Palm explained his grammatical activity by stating that the grammars of the first period as well as the works produced by Natura et Arte, of which de Haes and Elzevier were members, seemed to consist of ideas meant for scholarly discussion rather than lessons for the young. Echoing Elzevier (see Section 4.3), van der Palm wote:

wie immer hunne werken oordeelkundig heeft ingezien, zal gemerkt hebben, dat het oogmerk dier schryveren meer geweest zy der geleerde weereld' hunne vernuftige gedachten, als der jeugd' hunne lessen, medetedeelen; ja dat men zelfs eenige kundigheit, zoo niet van andere, ten minste van onze tale bezitten moet, wil men de vrucht van hunnen arbeidt plukken. Ons oogmerk, in tegendeel, is alleen der jeugd' dienstig te zyn: voor haer is het dat wy deze Spraekkunst opgestelt hebben; moetende men, naer onze gedachten, met de jeugd' beginnen, indien men immer gegronde hoop kan opvatten, dat onze Nederlandsche spraek, by de Nederlanders, op haren rechten prys gestelt al worden.

(van der Palm 1769-I: ${ }^{*}{ }^{r-v}$ ) 
anyone who has judiciously examined their works will have noticed that the goal of these writers has been to communicate their clever thoughts to the learned world rather than to communicate their lessons to the young; moreover, that one has to possess a certain knowledge - if not of other languages, then at least of our language - if one wants to profit from their work. Our goal, on the contrary, is merely to serve the young: for them, we have written our grammar; in our opinion, one has to start with the young if one ever wants to have reason to have high hopes that our Dutch language will be appreciated by the Dutch.

The criticism was similar to Elzevier's with respect to Moonen, except that van der Palm extended it to include the grammarians of the second period, such as Elzevier. Considering their works to be still too complicated, van der Palm aimed to render the contents more accessible by taking a different approach. He divided his grammar book into four separate, relatively short booklets on the assumption that new learning materials would generate renewed interest (van der Palm 1769-I: ${ }^{\star} 4^{\mathrm{r}-\mathrm{v}}$ ). He stressed that he did not provide anything new, but only simplified existing knowledge found, for example, in Moonen (1706), Séwel (1712) and de Haes (1764). His aim to render the contents more accessible affected both the form and the contents themselves. He avoided potentially confusing details and remarks, and restricted himself to a basic description of the grammar. As to the form, he avoided long sentences, subordinate clauses and participial phrases (Rutten 2009: 68). Furthermore, he reintroduced the age-old dialogue format, which was uncommon at the time in metalinguistic discourse. The dialogue was composed in such a way that the answers to the questions by themselves made up the grammar, so that readers were not forced to read the book as a dialogue (van der Palm 1769-I: ${ }^{\star} 4^{v}$ ). The dialogue format emphasised van der Palm's efforts to present concrete grammar lessons for the young instead of 'clever thoughts' for 'the learned'.

One aspect of simplifying the received body of knowledge consisted of reducing the text to its bare essentials. Van der Palm's (1769-I: 1) definition of grammar was founded on Séwel's (1712: 1), but whereas Séwel's took up one four-line sentence, van der Palm reduced it to the following dialogue:

Vr. Wat is de Spraekkunst?

Antw. De Spraekkunst is eene kennis van Letteren en Sprake.

(van der Palm 1769-I: 1)

Q. What is grammar?

Answ. Grammar is knowledge of letters and speech.

This is the standard procedure of simplification that van der Palm used throughout his grammar (Rutten 2009). In addition, he also reordered and elaborated observations made by his predecessors in order to present their linguistic insights in a more systematic manner. An example is the discussion of homonyms and 
near-homonyms. Séwel (1712: 63) briefly discussed orthographical and phonological variation focusing on a limited set of lexical items. De Haes (1764: 15-16) referred to Séwel, while adding a few examples. Van der Palm (1769-I: 46-52) distinguished between four different types of homonyms and near-homonyms that Séwel and de Haes had mixed, viz. homonyms which were not homographs (aert 'nature' and aerd 'earth'), homonyms which were also homographs (aes 'food' and aes 'ace'), homographs which were not homonyms (hóóp 'heap' and hoop 'hope'), and words that were neither, yet were often confused ( $n a$ 'after' and naer 'to'). Van der Palm also provided, per type, an alphabetical list of the most frequent words. In cases such as this one, van der Palm did not reduce the text found in the normative tradition. Instead, he reordered insights and problematic issues, and presented them in a clear and systematic way, thus reshaping received grammatical ideas into a coherent and comprehensible framework.

Van der Palm (1769) was part of an increase in grammar production in the northern Netherlands in the final decades of the eighteenth century, i.e. in the period of national grammar (Stijl/van Bolhuis 1776, 1778; van Bolhuis 1793, 1799; Wester 1797, 1799; van Varik 1799). Many of the new grammars resulted from the activities of private societies, demonstrating the relevance of sociability, that is, the phenomenon that men and women gathered in societies in order to discuss current affairs of a social, political, literary and/or scientific nature. The second half of the eighteenth century is characterised by a true explosion of such private societies. By 1800 , every town in the northern Netherlands had at least a couple of book clubs, literary societies, and scientific societies; even hundreds of villages had at least a book club. It is estimated that at the beginning of the nineteenth century, 3-5\% of the adult male population was or had been involved in one or more societies (Kloek \& Mijnhardt 2001: 103-104). Many societies organised lectures, produced essay volumes or periodicals, held essay competitions, and published the prize-winning essays. De Vries (2001) argues that the common goal of most societies was to civilise the populace, for which education was considered to be crucial.

In this context of public advancement, three interdependent topics were addressed repeatedly: language, education and the nation (see Chapter 2). Some societies, such as the Leiden-based learned society Minima crescunt, published scholarly treatises on linguistics in the periodical Maendelyksche By-dragen ter Opbouw van Neerlands Tael- en Dichtkunde ('Monthly contributions to the advancement of Dutch grammar and poetics', 1758-1763) and its successor Nieuwe By-dragen ('New contributions', 1763, 1766). Another Leiden-based society, Kunst wordt door Arbeid Verkreegen ('Art is Acquired by Effort'), published a normative grammar, but only for internal use (1770: 4-5). It continues the Vondelianist approach taken by de Haes, whose grammar (1764) was one of the main sources. A third Leiden-based society, the Maatschappij der Nederlandsche Letterkunde 
('Society of Dutch Language and Literature'), envisaged a national dictionary and grammar, but both projects failed (Van de Bilt 2009: 213-218; see Chapter 7).

One active participant in the debates on language, education and the nation was van der Palm. In 1761 and 1763, the Hollandsche Maatschappij der Wetenschappen ('Holland Society for the Sciences') held two essay competitions, the first on the physical education of children, the second on their emotional and intellectual education (Los 2005: 183-184). In the second contest, a silver medal was won by van der Palm, who explicitly argued for mother-tongue education at the earliest stage of the child's school career, stating that "the first thing that a child, in whatever state it is born, has to learn, is to read and write its Mother tongue, and this should not be ended, unless it has proceeded significantly" (van der Palm 1766: 72 [my translation]). In 1774, the Kunstliefde Spaart geen Vlijt ('Love of Art does not Spare Diligence') society in The Hague held an essay competition on the best education of the young. Van der Palm was one of the competitors. In 1782, the Zeeuws Genootschap der Wetenschappen ('Zeeland Society for the Sciences') in Vlissingen published the winning essays from a competition on the improvement of schools. Van der Palm, once more one of the winners, argued strongly in favour of knowledge of the mother tongue, among teachers as well as children. Children should learn the grammar of Dutch, for which de ligtste Spraekkunst 'the easiest Grammar' was needed. Referring to his own grammar of 1769, he continued: "we may recommend the one by $\mathrm{K}$. van der Palm, which is the easiest I know of, and primarily drawn up for the young" (Van der Palm 1782: 29 [my translation]).

After decades of discussion on the civilisation of the people, on education and on the mother tongue, the most important so-called reformist society was founded in 1784: the Maatschappij tot Nut van 't Algemeen 'Society for Public Advancement', in short: 't Nut. Arising from the middle classes, from people without political power or influence, 't Nut adhered to an explicitly inclusive ideology of public civilisation. It focused on and was open to members of many social and religious groups (Mijnhardt 1987: 264-270), including women (Baar-de Weerd 2009: 39-44) and Catholics, though not to Jews until 1864 (van der Meiden 2009: 269). 't Nut was highly successful, with departments in eight different towns and 470 members in 1787, 25 departments and 2,331 members in 1794, and 106 departments and over 8,500 members in 1810 (Mijnhardt 1987: 265, 290).

The ideal of inclusive citizenship was also at the heart of the democratic government of the Batavian Republic, founded in 1795. One of the first things its government called for was a national educational policy (see Chapter 2), for which it turned to 't Nut in 1796. Two years later, 't Nut published its influential educational report Algemeene denkbeelden over het nationaal onderwijs ('General ideas on national education', see Chapter 2), in which 't Nut argued for mother-tongue education in schools. In this context 't Nut stated that an eenvouwige, doch zaaklijke, 
Nederduitsche Spraakkunst 'an easy yet adequate Dutch grammar' was one of the things most required (Algemeene denkbeelden 1798: 6). The report also rejected the dialogic method in schoolbooks (Dodde 1971:27), so van der Palm (1769) did not suffice. As explained in Chapter 1,'t Nut had already called for a concise grammar of Dutch a few years before. It was only in 1799 that 't Nut published its own grammar (van Varik 1799).

Finally, the Enlightenment discourse on education and public advancement, and the tradition of normative grammar converged, and led to the official language policy of 1804 and 1805 . As will become clear in the next section, however, the gradual development towards the simplification of a complex body of grammatical rules was halted. The swift implementation of late eighteenth-century discursive ideals in concrete policy measures in the first decade of the following century is probably connected to the close-knit network structures that many of the participants were active in. An illustrative example is the case of Kornelis van der Palm, who had connections with various societies (see above), and who was also the father of Johannes Hendrik van der Palm, the minister for national education responsible for the newly developed official language policy.

\subsection{Nominal inflection as a test case}

The eighteenth-century development from elitist to national grammar, through an intermediate stage of 'civil' grammar, was first and foremost a discursive development that can be traced in metalinguistic texts, in the justifications given for metalinguistic activities, in the aims indicated, and in the target audiences and target registers. The development paralleled Enlightenment discourses about language, nation and the importance of education (Chapter 1). In the previous sections, I have given examples of eighteenth-century metalinguistic discourse illustrating the practical consequences of the changing ideas about the role of normative grammar in society. Specific educational strategies and a tendency towards simplification were among these practical consequences. In the present section, I will focus on one particular area of the grammar that has been a focal point of Dutch metalinguistic discourse from the sixteenth century onwards, viz. nominal inflection, which was part of etymology, i.e. morphology.

The interest in nominal inflection is immediately linked to two major and interconnected morphosyntactic changes characterising the history of northern Dutch, viz. the loss of inflection, also called deflection, and the change from a three-gender system to a two-gender system (Goossens 2008: 137). For Old and Middle Dutch, four inflectional cases are usually distinguished, viz. the nominative, genitive, dative, and accusative (van der Wal \& van Bree 2008: 132-135). The case system 
already started to weaken in the Middle Dutch period. Deflection implied a shift from synthetic to analytical forms, which meant that case endings were lost, while periphrastic prepositional phrases increased in usage. This can be seen clearly in synthetic genitives such as des 'of the' in the masculine and neuter singular, and der 'of the' in the feminine singular and in the plural of all three genders, commonly replaced by the analytical prepositional phrase van de 'of the' in modern Dutch, which lacks inflection on the definite article. The loss of inflection generates variation of historical synthetic forms such as des vaders 'of the father' and analytical prepositional phrases such as van den vader 'of the father', which can be even further reduced to van de vader. While synthetic genitives still occur in written texts of the seventeenth, eighteenth and nineteenth centuries, it is often assumed that a fully-fledged case system was not in use in Early and Late Modern spoken Dutch (Geerts 1966: 152; van der Horst 2008: 1074-1075).

Whereas the loss of inflection affected the whole language area, the change from a three-gender system to a two-gender system was mainly a northern innovation (Goossens 2008: 137-147). Also in the Early Modern period, the historically masculine and feminine gender merged into one category of common gender, facilitated by the widespread loss of inflectional markers. In southern variaties, the difference between the masculine and the feminine gender was maintained by introducing new inflectional markers such as $-n$ in the definite article den for the masculine singular, depending on the phonetic context. The feminine singular remained $d e$. In the north, de became the common form for both the masculine and the feminine singular. The neuter form was het, often reduced to ' $t$, both in the north and in the south.

The ongoing loss of inflection and the merger of the masculine and the feminine gender did not prevent northern grammarians from proposing a system of nominal inflection with three genders and four to six cases. Often, the vocative and the ablative were included in addition to the four traditional cases. The changes generated a lot of variation in usage, providing grammarians with different options: case endings v. no case endings, and synthetic v. analytical forms. The variation in usage was mirrored by the variation found in prescription, where considerable differences existed from 1584 onwards, when the first fully-fledged grammar of Dutch was published (Twe-spraack 1584). It continued to exist well into the eighteenth century (Rutten 2006: 216-262). There was not a single case where grammarians reached total agreement. Case endings such as $-r$ and $-n$ abounded as well as analytical forms and combinations of both. In the eighteenth century, this wealth of variation found in sixteenth- and seventeenth-century metalinguistic discourse was leveled out in so far as most grammarians allowed for only two options for each function.

In what follows, I will discuss the prescriptions for the three most heavily debated cases, viz. the genitive, the dative and the ablative, as found in the three stages of normative grammar distinguished in this chapter (elitist, 'civil', national). I use ten of the most well-known grammars, from Moonen (1706) to Weiland (1805a). 
The data are taken from the paradigms of the definite article or, in case these were lacking, from other paradigms such as those of the noun. I focus on the definite article, and will take Middle Dutch as a reference system (van der Wal \& van Bree 2008: 135). For the sake of clarity, I will only use the weakened forms of the definite article, for example de in the masculine nominative singular, which developed from the demonstrative pronoun die, which was also in use as a definite article in Middle Dutch, and was in fact not replaced by de before the sixteenth century (van der Horst 2008: 841-842).

For the genitive case, the Middle Dutch reference system comprises the following forms: des in the masculine and neuter singular, der in the feminine singular and as the generic plural form. Analytical variants consist of the preposition van 'of' and a form of the article that can either be inflected (den) or not (de). In the neuter, there is also variation of the historical form den and the nominative and accusative form het. Table 5 presents the results for ten normative grammars of the period 1706-1805.

Table 5. Genitive case of the definite article in ten normative grammars (1706-1805)

\begin{tabular}{|c|c|c|c|}
\hline & \multicolumn{3}{|c|}{ Genitive singular } \\
\hline & Masculine & Feminine & Neuter \\
\hline Moonen 1706 & des & der & des \\
\hline Verwer 1707 & des & der & des, van den \\
\hline Séwel 1712 & des, van den & der, van de & des, van het \\
\hline Elzevier 1761 & van de, des & van de, der & van het, den \\
\hline van der Palm 1769 & des, van den & der, van de & des, van het \\
\hline Stijl/van Bolhuis 1778 & des, van den & der, van de & van het, des \\
\hline van Bolhuis 1799 & van den & van de & van het \\
\hline Wester 1799 & des, van den & der, van de & des, van het \\
\hline van Varik 1799 & des, van den & der, van de & van het, des \\
\hline \multirow[t]{3}{*}{ Weiland 1805a } & des & der & des \\
\hline & \multicolumn{3}{|c|}{ Genitive plural } \\
\hline & Masculine & Feminine & Neuter \\
\hline Moonen 1706 & der & der & der \\
\hline Verwer 1707 & der & der & der, van de \\
\hline Séwel 1712 & der & der & der \\
\hline Elzevier 1761 & van de, der & van de, der & der, van de \\
\hline van der Palm 1769 & der, van de & der, van de & der, van de \\
\hline Stijl/van Bolhuis 1778 & der, van de & der, van de & der, van de \\
\hline van Bolhuis 1799 & van de & van de & van de \\
\hline Wester 1799 & der, van de & der, van de & der, van de \\
\hline van Varik 1799 & der, van de & der, van de & der, van de \\
\hline Weiland 1805a & der & der & der \\
\hline
\end{tabular}


Table 5 shows that there was a high level of agreement, but also still significant varation. Moonen (1706) presented only inflected forms in the genitive, clearly preferring the historical synthetic variants. Verwer (1707) largely followed Moonen (1706), but it should be noted that in the nominal paradigm, Verwer (1707: 20-22) presented solely analytical forms with very few inflected forms of the article. Séwel (1712) introduced more analytical forms. The ordering in Table 5, which follows his paradigms of the definite article (1712: 66-67), suggests that Séwel considered the analytical genitives as alternatives to the (primary) synthetic forms, but elsewhere (1712: 184-220) the order is reversed, or he mentioned only the synthetic forms. Contemporaries criticised him for such inconsistencies (Rutten 2006: 262-265).

After the period of elitist grammar, synthetic as well as analytical forms were considered appropriate in the genitive (Elzevier 1761; van der Palm 1769). Van der Palm (1769) consistently presented first the historical synthetic forms and then the analytical alternatives, illustrating his aim of rendering Moonen more accessible, in this particular case by presenting Moonen's prescriptions as well as the more common analytical forms.

When normative grammar became a matter of national concern, a second step was taken to simplify the case system. In his editing of Stijl's grammar (1776, 21778), van Bolhuis still largely remained within the realm of 'civil' grammar, giving both the synthetic and the analytical forms. However, in his concise grammar $(1793,21799)$ written for 't Nut, van Bolhuis radicalised his position, giving only the analytical forms in the paradigms, while allowing inflected articles (den) only in the masculine singular. Presenting this as an example of "normal declension" (1799: 27), he only discussed other synthetic forms in the text following the paradigm. Despite the fact that van Bolhuis clung to the six-case system, this was a grammatical revolution, resulting from the educational and inclusive approach characterising the discourse of the period. Van Bolhuis' prescriptions must have been closer to everyday usage than those of any grammarian before him. His grammar thus represented the national grammar's momentum. It was a brief moment, however, as Wester, who was coached by van Bolhuis when writing his grammar book (1797, ${ }^{2} 1799$; cf. Noordegraaf 1985: 227-228) re-introduced the synthetic genitives. When 't Nut published its own grammar (van Varik 1799), both synthetic and analytical forms were prescribed. The return to earlier prescriptions was completed when Weiland copied Moonen (1706) in his officialised grammar (1805a). A few years later Weiland published an abridged version of his grammar book, specially intended for schools, in which he repeated the prescriptions presented in Table 5, thus only mentioning the synthetic forms (1808: 50-51; see also below).

The general development from synthetic in the elitist period to synthetic and analytical around the middle of the century, to only analytical in the period of 
national grammar, and finally back to synthetic forms with Weiland (1805a), is also found in the dative and the ablative. The Middle Dutch reference system for the dative has den in the masculine and neuter singular, and also in all plural forms, while der is the feminine singular. The prototypical preposition associated with dative constructions is aan 'to'. Analytical variants may be inflected (den). In the neuter, the variation of het and den persists. See Table 6.

Table 6. Dative case of the definite article in ten normative grammars (1706-1805)

\begin{tabular}{|c|c|c|c|}
\hline & \multicolumn{3}{|c|}{ Dative singular } \\
\hline & Masculine & Feminine & Neuter \\
\hline Moonen 1706 & den & de, der & het, den \\
\hline Verwer 1707 & den & de, der & het, aen den \\
\hline Séwel 1712 & den, aan den & der, aan de & het, aan het \\
\hline Elzevier 1761 & den, aen den & der, aen de & aen het, aen den \\
\hline van der Palm 1769 & den, aen den & der, aen de & den, aen het \\
\hline Stijl/van Bolhuis 1778 & den, aan den & aan de, der & aan het, den \\
\hline van Bolhuis 1799 & aan den & aan de & aan het \\
\hline Wester 1799 & aan den & aan de & aan het \\
\hline van Varik 1799 & den, aan den & der, aan de & aan het, den \\
\hline \multirow[t]{3}{*}{ Weiland 1805a } & den & $d e, d e r$ & den, het \\
\hline & \multicolumn{3}{|c|}{ Dative plural } \\
\hline & Masculine & Feminine & Neuter \\
\hline Moonen 1706 & den & de & den \\
\hline Verwer 1707 & den & den & den \\
\hline Séwel 1712 & den, aan de & aan de & den \\
\hline Elzevier 1761 & den, aen den & de, aen de & den, aen den \\
\hline van der Palm 1769 & den, aen de & der, aen de & den, aen de \\
\hline Stijl/van Bolhuis 1778 & aan de, den & aan de, der & aan de, den \\
\hline van Bolhuis 1799 & aan de & aan de & aan de \\
\hline Wester 1799 & aan de & aan de & aan de \\
\hline van Varik 1799 & den, aan de & aan de, den & aan de, den \\
\hline Weiland 1805a & den & de, der & den \\
\hline
\end{tabular}

Table 6 shows that there was even more variation in the prescriptions for the dative than for the genitive. This is particularly clear in the feminine plural, where de, der and den occur. The preference for only analytical forms is now also found in Wester (1799). As with the genitive, synthetic forms were again used by van Varik (1799) in his grammar for 't Nut, while Weiland (1805a) restricted himself to synthetic forms.

Historically, there was no ablative in Dutch, the ablative function being commonly expressed by prepositional phrases from the earliest documented Dutch 
onwards (Quak \& van der Horst 2002: 37). The preposition van 'of, from' was used in metalinguistic discourse to represent the ablative. Analytic ablatives were preferred throughout the eighteenth century, as can be seen in Table 7. Variation is mainly found in the feminine singular, where the forms de, der and den occur. From van der Palm (1769) onwards, synthetic variants without prepositions were no longer used, until van Varik (1799) reintroduced der in the feminine singular. In the plural, no inflected forms of the article appear from van Bolhuis (1799) onwards. Weiland (1805a) did not consider the ablative to be part of the Modern Dutch case system.

Table 7. Ablative case of the definite article in ten normative grammars (1706-1805)

\begin{tabular}{|c|c|c|c|}
\hline & \multicolumn{3}{|c|}{ Ablative singular } \\
\hline & Masculine & Feminine & Neuter \\
\hline Moonen 1706 & van den & van de, der & van het, den \\
\hline Verwer 1707 & van den & van den & van het, van den \\
\hline Séwel 1712 & van den & van de & van het, van den \\
\hline Elzevier 1761 & van den & van de, der & van het, den \\
\hline van der Palm 1769 & van den & van de & van het, van den \\
\hline Stijl/van Bolhuis 1778 & van den & van de & van het \\
\hline van Bolhuis 1799 & van den & van de & van het \\
\hline Wester 1799 & van den & van de & van het \\
\hline van Varik 1799 & van den & van de, der & van het, van den \\
\hline \multirow[t]{3}{*}{ Weiland 1805a } & - & - & - \\
\hline & \multicolumn{3}{|c|}{ Ablative plural } \\
\hline & Masculine & Feminine & Neuter \\
\hline Moonen 1706 & van den & van de & van den \\
\hline Verwer 1707 & van de & van de & van de \\
\hline Séwel 1712 & van den & van de & van de \\
\hline Elzevier 1761 & van de, van den & van de & van de, van den \\
\hline van der Palm 1769 & van de, van den & van de & van de, van den \\
\hline Stijl/van Bolhuis 1778 & - & - & - \\
\hline van Bolhuis 1799 & van de & van de & van de \\
\hline Wester 1799 & van de & van de & van de \\
\hline van Varik 1799 & van de & van de & van de \\
\hline Weiland 1805a & - & - & - \\
\hline
\end{tabular}

The prescriptions for the use of the genitive, dative and ablative case in ten normative grammars from Moonen (1706) to Weiland (1805a) change from a preference for synthetic forms to a preference for analytical forms, and then back to synthetic 
forms. As the analytical forms were common in the spoken language and in many written registers (Nobels \& Rutten 2014; Simons \& Rutten 2014), the change toward these forms parallels the discursive development from elitist to national grammar, justified by the idea that a national grammar should include common forms, and not only forms that characterise elitist text types such as poetry.

The remarkable return to synthetic forms after the gradual rise of analytical forms, followed by van Bolhuis's clear preference for analytical forms, can be explained with reference to different registers or stylistic levels. Van Varik (1799: 12; my translation) commented on his genitive and dative paradigms "that we have two ways of speaking in our language, viz. a familiar and a polite or elevated way; everyday usage teaches us the familiar [way] as a matter of course; and reading well written books teaches us the polite style". So the analytical forms represented the familiar style of everyday usage, while the synthetic forms belonged to the polite or elevated style. Ten Kate (1723) had introduced three stylistic levels in the field of grammar, which he borrowed from the rhetorical tradition (see also Section 3.6). In ten Kate (1723), the declension of the definite article was one such topic where extensive paradigms with many different forms were broken down into three stylistic levels (cf. de Bonth 1998: 164-165).

The grammatical variants generated by the loss of inflection and the rise of analytical constructions were handled differently by the eighteenth-century grammarians discussed in this section. The development from elitist to national grammar was paralleled by a shift from synthetic to analytical forms, and thus by an appropriation of everyday usage. The shift towards analytical forms also implied a shift from 'higher' registers to 'lower' registers. This was reflected in ten Kate's (1723) and van Varik's (1799) efforts at distributing the grammatical variants over different stylistic levels. Ultimately, the difference between van Bolhuis (1793/1799) and van Varik (1799) comes down to the question of the register on which the national grammar should be founded. Should the 'standard' language, which is being constructed in these grammar books, reflect the supposedly everyday usage of 'the nation', following the ideal of inclusive citizenship? Or should it be based on the highest stylistic level of the nation's elite, to which the rest of the population should turn for guidance? Weiland's (1805a) choices strongly suggest that the latter was the case.

Turning to the next episode in the period of national grammar, i.e. the first decades of the nineteenth century, it is interesting to see how genitival constructions were treated in metalinguistic discourse. Similar to the research reported on above, the prescriptions for the genitive singular and plural of the definite article are taken from the paradigms offered in the sources. The selection of sources again comprises Weiland's national grammar (1805a). 
Table 8. Genitive case of the definite article in eight normative grammars (1802-1825)

\begin{tabular}{llll}
\hline & \multicolumn{3}{c}{ Genitive singular } \\
\cline { 2 - 4 } & Masculine & Feminine & Neuter \\
\hline Rudimenta 1802 & des, van den & der, van de & des, van het \\
Weiland 1805a & des & der & des \\
Weiland 1805b & des & der & des \\
Rudimenta 1805-I & des, van den & der, van de & des, van het \\
Siegenbeek 1814 & des, van den & der, van de & des, van het \\
Weiland 1820 & des & der & des \\
Puikers 1824 & des & der & des \\
Kirchdorffer 1825 & des, van den & der, van de & des, van het \\
\hline & & Genitive plural & \\
\cline { 2 - 4 } & Masculine & Feminine & Neuter \\
\hline Rudimenta 1802 & der, van de & der, van de & der, van de \\
Weiland 1805a & der & der & der \\
Weiland 1805b & der & der & der \\
Rudimenta 1805-I & der, van de & der, van de & der, van de \\
Siegenbeek 1814 & der, van de & der, van de & der, van de \\
Weiland 1820 & der & der & der \\
Puikers 1824 & der & der & der \\
Kirchdorffer 1825 & der, van de & der, van de & der, van de \\
\hline
\end{tabular}

As can be seen in Table 8, Weiland only mentions synthetic forms in his paradigms, not just in the official (1805a) grammar, but also in the other two publications, viz. the Beginselen 'Principles' of (1805b), a summary of the voluminous (1805a) book, and also in later years, in the 1820 schoolbook. Puikers (1824) follows Weiland. All other prescriptions are identical, not just with regard to the choice of forms, but also in that they offer both the synthetic and the analytical alternative, and always in this order; the analytical construction is never put first. In terms of the above-mentioned changes in grammar writing in the eighteenth century, there is a return to the prescriptions of the period of elitist grammar in the works of Weiland and Puikers (only synthetic forms), and a return to the prescriptions of the period of 'civil' grammar in the other works (synthetic and analytical forms). In both cases, there is a move away from the radical choice to focus only on analytical forms in the late eighteenth century. On the contrary, the synthetic genitive is the prime variant in all texts from the period 1800-1830.

Weiland $(1805 \mathrm{a}, 1805 \mathrm{~b}, 1820)$ does mention the analytical forms in the running text. Such mentions are usually limited to the observation that genitival constructions can also be rendered with the preposition van (Weiland 1805a: 76; cf. 
Siegenbeek 1810a: 15; Schilperoort 1806: 33). In Rutten (2016d), I also argue that grammarians in this period do not offer clear conditions under which the preferred synthetic genitive and the alternative option of the analytical genitive should be used. Neither do the usage patterns found in the grammar books themselves offer any indications of the distribution of these variants. This means that there was an enormous gap between language use and language norms. Whereas the population at large was apparently supposed to learn the synthetic genitive, which had largely disappeared from colloquial language, metalinguistic discourse mainly provided tools to acquire the historic form itself, but did not indicate in which contexts it was an appropriate form. One of the main questions, therefore, is to what extent the prescriptions found in metalinguistic texts from this period have exerted any influence on actual language use (see Chapter 11).

\subsection{Final remarks}

With the gradual widening of the target audience, normative grammar developed from fairly elitist at the beginning of the eighteenth century to a matter of national concern towards the end of the century. This change was reflected in educational strategies employed by grammarians, who particularly aimed at the simplification of the contents of grammatical texts in order to reach larger sections of the population. In the case of nominal inflection, one of the main concerns of Early and Late Modern Dutch linguists and grammar writers, this led to the growing importance of analytical forms at the expense of the historical synthetic forms. However, after a gradual simplification of the prescriptions, there was a normative return to the old synthetic genitive without however offering clear usage conditions for the distribution of the synthetic and the analytical variants. Weiland (1805a) played a crucial role in this return to a preference for synthetic forms. 

PART II

Myth building 



\section{CHAPTER 5}

\section{The Golden Age Myth}

\subsection{Introduction}

The rise of cultural nationalism, including linguistic nationalism in the eighteenth century, and the subsequent politicisation of language signal the establishment of standard language ideology (SLI) as a viable sociopolitical approach to the relationship between language and society, and as the prime language ideology in the age of nationalism. As discussed in Chapter 2, a crucial aspect, if not the most important characteristic of SLI is its reliance on the concept of homogeneity. In his study of language myths in the history of English, Watts (2012: 595-596; cf. Watts 2011) calls the myth of homogeneity the "underlying" language myth, i.e. the foundation of all other language myths. In the same vein, Chapter 2 discussed a range of discursive operations feeding on the concept of homogeneity. These discursive operations are crucial to an understanding of the sociolinguistic changes in the eighteenth and nineteenth centuries, and include iconisation, erasure, authenticisation and historicisation. In Chapters 5 and 6, I will discuss two language myths that characterise the Dutch situation around 1800, viz. the Golden Age Myth and the Myth of Neutrality. Both depend strongly on the concept of homogeneity and related discursive operations.

The study of language myths has attracted quite some attention over the past few decades (e.g. Bauer \& Trudgill 1998; Watts 2011; Anderwald 2012). Following earlier work, I describe language myths as communally shared stories about the form and function of language (e.g. Watts 2011: 10). Language myths are produced and reproduced in discourse, and discursively transmitted to future generations. They usually reveal widely held beliefs among the members of a speech community. Well-known language myths found in many communities relate to the superiority of a particular language or variety over other languages or varieties, the longevity of a certain language, or its old age. Language myths are narratives, and as stories that help construct a group identity, they are variable (Watts 2011:21-22). Watts (2011) also stresses that many language myths have become integral parts of the generally accepted history of English, and are thus as much present in expert studies as in lay perceptions of linguistic history. For example, the myth of the longevity of modern languages, and their supposedly unbroken development from the early Middle Ages up to the present day, can be found in many textbooks, and has in 
fact been an important impetus for the field of historical sociolinguistics (Watts \& Trudgill 2002; Elspaß \& Langer 2012).

Language myths can also become part of relatively more fixed perspectives of sociopolitical reality and the role of language therein. They can be integrated into sets of beliefs that guide social action and inform political views. In other words, language myths can be politicised and ideologised. What I want to argue here and in Chapter 6 is that existing stories about the language of the Dutch Golden Age and about the supposed neutrality of specific forms of language became part of the nationalist perspective on language and society here referred to as standard language ideology. While the concepts and the terms of myth and ideology are sometimes used interchangeably and often seem to refer to similar objects of inquiry, which can be roughly defined as "cultural conceptions of the nature, form, and purpose of language" (Gal \& Woolard 2001: 1), I will try to keep them separate here, considering language ideologies to be sociopolitical systems of ideas about language and society that feed on language myths as discursively constructed and communally shared narratives (Watts 2011: 21-23). Standard language ideology, then, is an overarching, sociopolitical ideology connected to the legal and administrative integration of the northern Low Countries, involving a policy to create a nation-state, also at the cultural level, for example through language laws and educational laws. SLI is a broad and abstract notion that incorporates other metalinguistic phenomena, such as metalinguistic discourse and policy measures. SLI itself can mainly be accessed indirectly, for example through laws prescribing the national language, or through talk about talk. Talk about talk, or metalanguage, often takes the form of concrete stories about the imagined form and/or function of the language, i.e. of language myths.

This is not the place to discuss all the language myths that have played an important role in the history of Dutch. Moreover, many of the English myths deconstructed by Watts (2011) are also part of the history of other languages, including Dutch, so that the idea that Dutch is an ancient language, with an unbroken tradition from the Middle Ages up to the present day, the idea that there are pure, polite and legitimate forms of the language, and that there is a stable, invariant and homogeneous type of Dutch can easily be detected in Dutch metalinguistic discourse (see also Chapter 6). I will first discuss recent research on language myths in the history of Dutch in Section 5.2, before focusing on two language myths that characterise the Dutch situation perhaps even more strongly than other language situations, and that are inherently connected to the nation-building process in the decades around 1800. Section 5.3 is devoted to the Golden Age Myth, Chapter 6 to the Myth of Neutrality. 


\subsection{Language myths and the history of Dutch}

In recent research, a variety of language myths have been discussed, in particular as part of the intriguing polycentric north-south dynamics characteristic of the history of Dutch. With respect to the southern Dutch situation of the eighteenth and early nineteenth centuries, it has been argued that language histories employ various myths that often date back to the historical period itself. The sociolinguistic situation has been described as chaotic, both in actual usage and in normative discourse, for which the terms orthographical chaos myth and many norms myth have been introduced. The main idea is that written southern Dutch in this period was highly variable, specifically the spelling, and that moreover, spelling guides and grammars were equally variable. This view of normless and chaotic Dutch in the south contrasts sharply with the myth of northern uniformity, according to which northern Dutch of the same period underwent strong standardisation to the extent of being a homogeneous written language.

In addition to this fairly negative view of the written language in the south, it has been argued that the period also suffered from what could be called dialectisation, i.e. a restriction of the use of Dutch to localisable forms in the spoken language. This myth of dialectisation is the counterpart to another myth, viz. the myth of Frenchification. Thus, the sociolinguistic situation has often been depicted as one in which originally Dutch-speaking elites resorted to French, both in the spoken and the written code, as a consequence of which Dutch became a socially and regionally restricted spoken language.

These myths have been introduced and deconstructed in various publications (Vosters, Rutten \& van der Wal 2010; Vosters et al. 2012; Vosters \& Rutten 2015), and it has been argued that written southern Dutch of the eighteenth and nineteenth centuries was quite uniform, both in actual usage and in metalinguistic discourse, and not necessarily less uniform than written northern Dutch. In fact, the north also knew variation in usage and prescriptions, and often the patterns in the south are very similar to the patterns in the north. Whereas it is difficult to make definite claims about the spoken language, it is clear that Frenchification, and particularly the fear of Frenchification, was a pan-European phenomenon (see also Chapters 7 and 8). It is, however, characteristic of southern Dutch metalinguistic discourse and language histories to connect language loss to the multilingual practices of particular elites.

Providing empirical evidence against the reliability of the myths only underlines their significance as discursive constructions that reveal people's ideas about sociolinguistic space. Painting a negative picture of the southern situation was particularly interesting for members of pro-Dutch and (moderately) anti-French 
emancipatory movements. They also embraced the idea of northern uniformity. This uniformity was simultaneously constructed in northern metalinguistic discourse. Of course, the language policy resulting in Siegenbeek (1804a) and Weiland (1805a) also implied a high degree of actual uniformity at the level of official codification. In addition, the two myths that will be discussed here and in Chapter 6 are examples of narratives indexing a specific variety of written Dutch as the uncontested and unchanging standard variety of the Dutch language area.

The two myths are also chosen because they seem to represent important discursive processes that have been analysed and distinguished in research on language ideology and language policy over the past few years. Wright (2012) discusses language policy in the history of western European languages, building on the classical opposition of the French and German models of nation-state formation. In the French model of civic nationalism, emphasis is put on the contractual and legal nature of state formation. Members of the population are primarily citizens who engage in a process of uniformisation, and hence constitute a Staatsnation (also Willensnation). Top-down policy measures aim "to create a linguistically homogeneous people" (Wright 2012: 59), whereby education is one of the main means to achieve this. Geeraerts (2003) refers to the French model as rationalist. Language, and in particular standard language, is seen as a neutral medium of communication. Mastering the standard enables citizens to participate actively in democratic and social processes. Both Wright (2012: 59-61) and Geeraerts (2003) stress that diversity, for example regional variation, is inherently problematic for the French/ rationalist model, as it would hamper political participation.

Besides this prototypical description of the so-called French model, Wright (2012) and Geeraerts (2003) also distinguish the German or Romantic model of what is often called the Kulturnation (also Sprachnation). In the German model, the basic ethno-linguistic assumption entails that the nation as a cultural unit predates the state. This is the position prototypically associated with Herder, in which language is an iconic, authentic and historically extant expression of the national character (see also Section 2.3). According to Geeraerts (2003: 40), the expressive and identitary function of language also implies that language variation is positively evaluated "as expressing different identities". This may apply to recent work on minority languages - Geeraert's main point of reference - but not to Late Modern cultural nationalism. As argued in Section 2.3, Herder's language ideology is monoglossic and aims at homogeneity (Bauman \& Briggs 2003: 195). Referring to nationalists of either type, Wright (2012: 64) states that "[a]ll nationalists believe that the nation-state is ideally a monolingual entity".

When comparing the language ideologies of Locke and Herder, Bauman \& Briggs (2003: 190) identify a crucial difference: 
Ultimately, Locke anticipates the realization of a pure language, autonomous from nature and society, which may then serve for the scientific discovery of natural truth and the establishment of a rationally founded, stable society. Herder, by contrast, insists from the beginning on a conception of language as a nature - society hybrid, simultaneously natural and social, which serves in turn as the instrument of social purification, the foundation of a homogeneous national society that is at the same time a fulfillment of human nature. Such fundamental epistemological and axiological differences cannot help but lead in different intellectual and ideological directions and yield different visions of modernity. (Bauman \& Briggs 2003: 190)

The difference signaled here maps onto the distinction made by Gal \& Woolard (2001: 6-9) in their analysis of the discursive construction of political and linguistic authority (cf. Woolard 2016). Claims to political and linguistic authority depend on specific conceptualisations of sociolinguistic space, and the two main perspectives that Gal \& Woolard distinguish in this context are anonymity and authenticity. Anonymity involves "a form of aperspectival objectivity", a "voice-from-nowhere" (Gal \& Woolard 2001: 6, 7). It entails a universalistic approach to language according to which there is an objective and neutral form of language that belongs to the community as a whole and simultaneously to no one in particular. Horner \& Kremer (2016) observe that such a discourse of anonymity resonates with standard language ideology (cf. Gal \& Woolard 2001: 8). It is closely connected to the French or rationalist model that also stresses the emancipatory and democratic function of the standard language as a neutral medium of communication. The Herderian, German, Romantic position, on the other hand, ties in with discourses of authenticity, with the idea of the language as an authentic representation of the soul of the people, dating back to ancient times (see also Section 2.3). According to Horner \& Kremer (2016), the concept of authenticity ties in with the one nation, one language ideology, that is, with cultural nationalism.

Gal \& Woolard (2001) do not claim that anonymity and authenticity are mutually exclusive processes. Quite the contrary, they underline that they are often intertwined (Gal \& Woolard 2001: 7). In her analysis of the discourses surrounding Spanish and Catalan, Woolard $(2008,2016)$ also points out that anonymity and authenticity are often closely connected, and that the dominance of one of the two perspectives over the other can change over time. Similarly, Horner \& Kremer (2016) discuss the interplay of discourses of anonymity and authenticity in the case of present-day Luxembourg and Luxembourgish, indicating that the two are often combined, and are simply different perspectives and interpretations of the same sociolinguistic situation.

This is also what is found in the historical Dutch case that is the topic of this study. The two myths that will be discussed in Section 5.3 and in Chapter 6 represent the two main perspectives of authenticity in the case of the Golden Age Myth, 
and anonymity in the case of the Myth of Neutrality. The two myths are closely intertwined and highlight different aspects of the politicised cultural nationalism characterising the late eighteenth and early nineteenth centuries. They are, in other words, part of the same discursive construction of Dutch as a national language. What the two myths illustrate is the combination of the two conceptually distinct perspectives of anonymity and authenticity in a concrete historical setting, and, in fact, their inseparability in the Dutch case.

As was mentioned in Section 2.2, it is commonly assumed that the rise of cultural nationalism preceded the actual state formation in the northern Netherlands in the eighteenth century. This implies that there is a clear resemblance to the prototypical German or Romantic model as outlined above. The Myth of the Golden Age entails that the seventeenth century, particularly in the politically and culturally dominant areas of Holland and Utrecht, constitutes the moment in history when the Dutch language reached its ultimate state of perfection, mirroring the greatness of the Dutch nation. It became a linguistic point of reference for many decades and even centuries to come. In the decades around 1800, this view of seventeenth-century Dutch as an authentic point of reference in history was integrated into contemporary nationalist discourse.

Simultaneously, a discourse of anonymity was applied to the same supraregional version of written Dutch, in keeping with the French or rationalist model. The national language was considered as a neutral tool for supraregional communication between all the members of the imagined community of the northern Netherlands. In addition, it was seen as a tool of emancipation that would help members of the nation gain access to the rich rewards of the Enlightenment. As I will argue in Chapter 6, this prototypical example of a discourse of anonymity at the same time drew on notions of authenticity. Attaching authenticity to the standard or national language implied denying authenticity to non-standard language such as dialects. I will argue in Chapter 9 that these were subject to processes of folklorisation instead.

\subsection{The Golden Age Myth}

The Dutch Golden Age is the period of the late sixteenth and the seventeenth century. Usually, this period is labeled golden primarily on account of its economic success, particularly of the province of Holland and its main city Amsterdam. Within a few decades, a region torn by war and social upheaval transformed into an economic superpower and the European centre of trade (Israel 1996: 337; Frijhoff \& Spies 1999: 18). The period is also well known for the Dutch school in painting (including Vermeer, Hals, Rembrandt) and for its literary production (including 
Vondel, Hooft and Bredero). In addition, the period is often considered seminal in the formation of the (northern) Dutch standard variety. Donaldson (1983), for example, gives his chapter on seventeenth-century Dutch the revealing title "The seventeenth century - the birth of ABN". ABN refers to Algemeen Beschaafd Nederlands 'general cultivated Dutch', an outdated name for standard Dutch, which still figures in common usage. ${ }^{1}$ The basic idea developed by Donaldson and by many authors before and after him is that Dutch was standardised in the late sixteenth and, in particular, in the seventeenth century. This is what I call the Golden Age Myth.

The Golden Age Myth is an example of what Wodak et al. (2009: 24) call a foundational myth, and a myth of origin. ${ }^{2}$ The Golden Age Myth is neither the first nor the only Dutch myth of origin (Kloek \& Mijnhardt 2001: 215-217). From the sixteenth century onwards, another foundational myth dominated historical discourses, viz. the so-called Batavian Myth, according to which the ancient tribe of the Batavians living in the Low Countries at the beginning of the Common Era were to be considered the immediate ancestors of the sixteenth-and seventeenth-century people living in the northern Low Countries, particularly in Holland (Haitsma Mulier 1996; Kloek \& Mijnhardt 2001: 215; van Sas 2004: 49). The Batavian Myth would remain important well into the eighteenth century and even inspired the official name of the Dutch republic that was proclaimed in 1795, viz. the Batavian Republic (Section 1.2). As van Sas (2004: 43) observes, however, the Dutch collective auto-image or national myth changed several times from the sixteenth century to the present, and one important change was around 1800, when the Golden Age Myth replaced the Batavian Myth. According to Kloek \& Mijnhardt (2001: 215), an important reason for the eventual failure of the Batavian Myth was the fact that it was tied too closely to the province of Holland instead of to the Republic as a whole.

References to the literary language of the seventeenth century as the perfect example of fully cultivated Dutch date back to the late seventeenth century (Section 5.3.1). Around 1800, the adoration of the poets of the so-called Golden Age becomes part of SLI (Section 5.3.2). In the course of the nineteenth and twentieth centuries, the idea that Dutch was standardised in the Golden Age develops into a core element of language histories (Section 5.3.3).

1. Van der Sijs (2004), for example, is a history of Dutch written for the general public. The full title is Taal als mensenwerk. Het ontstaan van het $A B N$ ('Language as human activity. The origins of $\left.\mathrm{ABN}^{\prime}\right)$.

2. Wodak et al. (2009: 26): "the discursive construction of national identity revolves around the three temporal axes of the past, the present and the future. In this context, origin, continuity/ tradition, transformation, (essentialist) timelessness and anticipation are important ordering criteria”. 


\subsubsection{Looking back on the Golden Age}

The words of the grammarian Christiaen van Heule in 1625 are almost prophetic. In his Dutch grammar of that year, he discusses the topic of rijmverlof'poetic licence'. After two pages, he breaks off the discussion by saying that he will not provide any further rules for poetic licence, one reason being that the number of contemporary laudable poets is still small (van Heule 1625: 83). In a theory of language in which auctoritas and good usage are crucial concepts (Rutten 2005; Ayres-Bennet \& Seijdo 2013), a lack of laudable poets constitutes a major empirical problem. The remark is missing from van Heule's revised edition of 1633, which may indicate a growing awareness of the vibrant literary culture in Holland at that time. As mentioned above, the first half of the seventeenth century is often considered the Golden Age of Dutch literature, up to the present day. The two main poets associated with the period are P. C. Hooft (1581-1647) and Joost van den Vondel (1587-1679).

Hooft and Vondel were already considered great authors during their lifetime, but especially from the late seventeenth century onward, a process of canonisation

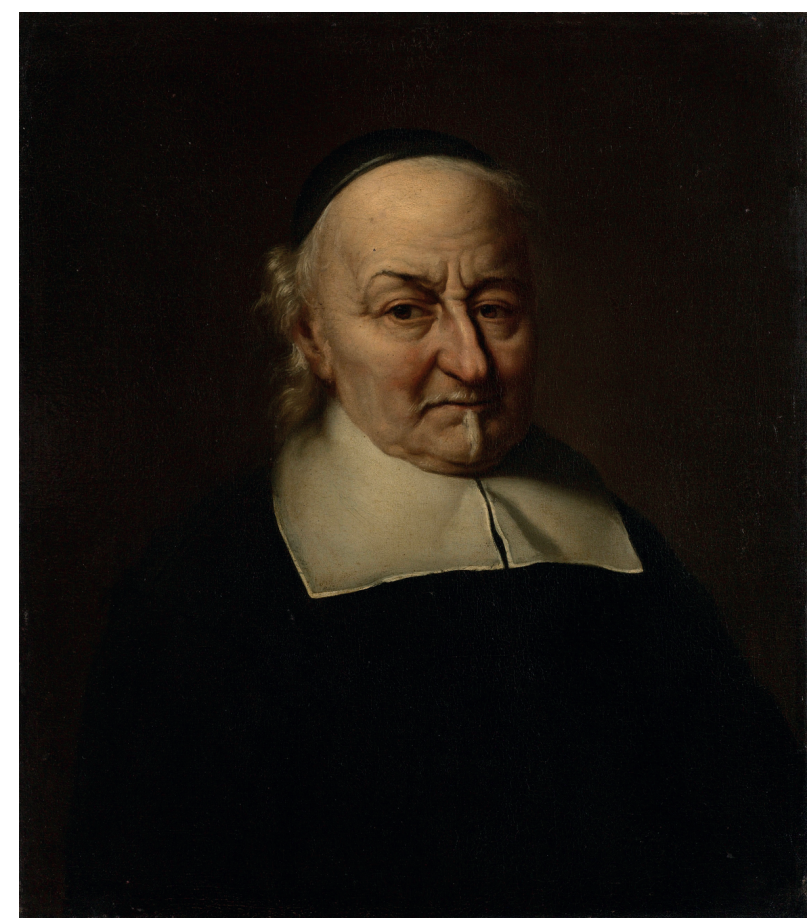

Figure 1. Joost van den Vondel (1587-1679; by Philip de Koninck).

Collection Rijksmuseum Amsterdam 


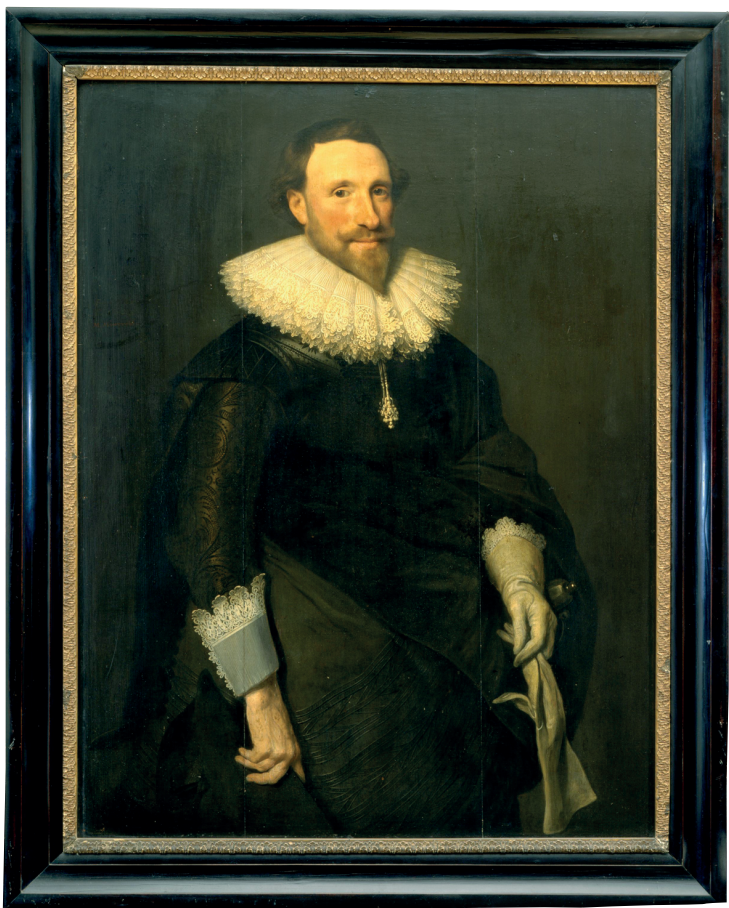

Figure 2. Pieter Cornelisz. Hooft (1581-1647; by Michiel van Mierevelt). Collection University of Amsterdam

set in that would determine the history of Dutch literature up to the present day (Rutten 2003a). This process of canonisation was a result of both literary and linguistic motivations, according to which literary excellence and linguistic purity were mutually dependent, and in fact inseparable. The two befriended ministers Johannes Vollenhove (1631-1708) and Geeraert Brandt (1626-1685), though of different Protestant denominations, were crucial in the early stages of the canonisation. Brandt published biographies of Hooft (1677) and Vondel (1682), an honour that he otherwise only paid the sea hero Michiel de Ruyter (1607-1676). The biographies were part of Brandt's editions of works of Hooft and Vondel, which he prepared with the assistance of Vollenhove (Dibbets 2007: 76). Vondel considered Vollenhove as one of his artistic 'sons' (Dibbets 2003a). Likewise, Vollenhove considered Vondel to be his artistic 'father', given the fact that the library of the University of Amsterdam holds a manuscript by Vollenhove comprising linguistic advice provided by Vondel during meetings with Vollenhove (Dibbets 2003a: 22). 
Arguments for the high quality of Hooft's and Vondel's literary works are often of a linguistic nature in this period, and simultaneously their names dominate metalinguistic discourse in the following decades. Vollenhove fulfilled the role of linguistic advisor of another minister, Jacobus Nylöe, who published the first edition of his style guide and introduction to Dutch grammar in 1703 (Dibbets 2003a: 1921). The years around 1700 were characterised by many close contacts between linguistically interested admirers of Hooft and particularly Vondel (Dibbets 1992, 2003a). Another member of this network was Arnold Moonen, who published an authoritative grammar of Dutch in 1706 (Schaars 1988). A related author was Petrus Francius, who published an essay on Dutch in 1699 , focusing primarily, though not exclusively, on spelling. He mentioned Hooft and Vondel as prime examples of good usage, along with Vollenhove, Brandt and Moonen (Dibbets 1995). Another related author was David van Hoogstraten, who wrote mainly on grammatical gender (1700; Rutten 2006). Somewhat later, Balthazar Huydecoper published a linguistic and literary commentary on the works of Vondel (1730; de Bonth 1998). Most of the grammatical works produced at the beginning of the century went through several reprints and revised editions well into the eighteenth century.

For the continual references to the works of the two great seventeenth-century poets, and to Vondel in particular, the period has been called Vondelianist (Rutten 2006). Early on, the circle of authoritative poets and language experts was extended to include Vondelianists such as Vollenhove, Brandt and Moonen. Schaars (1988: 59-63) says that the majority of the sample sentences of the syntax part in Moonen's 1706 grammar are taken from the works of Vondel. Perhaps the most illustrative example of Vondelianism is constituted by the works of van Hoogstraten. By 1700 , the historical three-gender system had largely given way to a two-way system of common and neuter gender in the spoken language of Holland. In written literary language, van Hoogstraten argued, the three-way system of masculine, feminine and neuter nouns ought to be maintained. Vondel and Hooft, as the language experts par excellence, had direct access to the original grammatical gender of nouns, so that van Hoogstraten excerpted their works, alphabetised nouns, and indicated the gender, providing quotations from Vondel and Hooft as evidence (Rutten 2006). A prototypical example is:

LEEU $m$. Eerst verscheurde hy eenen jongen brullenden leeu, Vondel voor Samson. (van Hoogstraten 1700: 52)

This should be read as follows: the word leeu 'lion' is masculine $(m)$, which is evidenced by the quote from Vondel's introduction to his play Samson, originally published in 1660. In the line Eerst verscheurde hy eenen jongen brullenden leeu 'first he tore apart a young roaring lion', the accusative ending -en on the article and the adjectives signal the masculine gender. 
In this process of canonisation, in which grammar was so important, references to other periods than the seventeenth century also occurred. Authors such as van Hoogstraten and Huydecoper as well as Adriaen Verwer (van de Bilt 2009) did not consider the seventeenth century as just a period of linguistic purity. To them, the seventeenth century was a period of renewed purity of the language. Verwer and van Hoogstraten distinguished various stages in the history of Dutch (Rutten 2003b). Their chronologies were not entirely similar, yet they agreed that the thirteenth, fourteenth and early fifteenth centuries constituted a fortunate period of grammatical regularity, especially in the thirteenth-century works of Melis Stoke. From the late fifteenth century onwards, and particularly from 1477 when the Habsburgian reign set in, the Dutch language deteriorated due to foreign influence (see also Chapter 8). The new period of purity was marked by the presumed meetings on literary and linguistic matters from 1624 onward, organised at Hooft's castle at Muiden, and attended by Vondel, among others. At these meetings, the poets involved were said to have debated as well as decided on poetical and grammatical issues, a somewhat Romantic view of the Golden Age poets that has later been dismissed as a myth (Wiskerke 1995: 326). Similarly, Huydecoper was a true Vondelianist, but he also cherished 'ancient' - i.e. Middle Dutch - poets such as Stoke, and was in fact a successful medievalist himself (de Bonth 1998: 99108). While the historical point of reference constituting purity or perfection in these cases was not located at the beginning of the Common Era, but in the High Middle Ages, the line of reasoning is very similar to Batavian Myth (Rutten 2003b). Continuity between the seventeenth century and another period much farther back in time is created by stipulating linguistic perfection at both points in time. At these two stages, the Dutch language revealed itself as it really, authentically was, viz. a pure and regularised language. In between, a period of foreign rule had corrupted both political structures and the language (cf. Section 5.3.2).

The Vondelianists from c. 1700 strove for Dutchness, in the sense of Latinitas or Hellenismos. This means that language norms advocated by these language experts were founded on the literary language of a bygone period, and were therefore mainly accessible to those who had the time, experience and skills to devote themselves to the study of those sources from the past (Rutten 2006: 394; Versteegh 1986). As a consequence, the normativity of these language experts did not extend much beyond their own circle of ministers, professors and schoolteachers with literary ambitions. The approach is utterly elitist (see Sections 3.2 and 3.3).

Already in the second half of the seventeenth century and the first decades of the eighteenth century, the idea that the best possible Dutch literature, both from a literary and a linguistic perspective, had been produced in the seventeenth century gained firm ground in metalinguistic discourse. The dominance of the Vondelianist approach would determine the course of normative grammar in the eighteenth 
century (see Chapter 4). In the period of national grammar (Section 3.4), the view of Vondel and Hooft as representing the most 'authentic' stage in the development of the Dutch language was integrated into the dominant nationalist discourse, and became part of SLI.

\subsubsection{Nationalising the Golden Age}

The end of the eighteenth century saw the rise of a new text genre: the history of Dutch literature (Wiskerke 1995; Kloek \& Mijnhardt 2001: 491-499; Petiet 2011). Its rise was closely linked to the nationalist enterprise that dominated Dutch Enlightenment discourse and politics. Siegenbeek, the author of the official 1804 spelling, was a prominent representative of this new genre (see Chapter 8). Another key figure was Jeronimo de Vries, who had worked closely together with Siegenbeek (Wiskerke 1995; Jensen 2018). The historical model applied by literary historians of this period identifies the first half of the seventeenth century as the point de la perfection (Wiskerke 1995: 208, 265) in the history of Dutch literature. In keeping with their cyclical model, the period before the Golden age is usually considered one of decline. Similarly, from the second half of the seventeenth century onwards Dutch literature and Dutch culture generally were again in decline, particularly in the eighteenth century, which suffered from Frenchification. Likewise, the fifteenth and seventeenth centuries had suffered from Frenchification, when the Low Countries were under Burgundian and Habsburg rule (Johannes 2002). It is only towards the end of the eighteenth century that a revival of Dutch literature can be witnessed. In sum, authors from around 1800 looked back upon history to find a historical moment, sandwiched between two phases of Frenchification, that could function as an absolute point of reference, as a valuable anchoring point (Coupland 2003: 419): this moment was found in the seventeenth century or Golden Age.

In this backward-looking and essentialist discursive move, the concept of authenticity that is at stake is most closely related to the type of sociolinguistic authenticity that Coupland (2003: 421) defines as "language indexing authentic cultural membership", viz. of a certain community, in our case the Dutch nation (see also Coupland 2014). To understand how the language of a small group of literary authors from the seventeenth century or Golden Age became subject to authenticisation and developed into an integral part of SLI, thus signaling the collective culture of the members of the nation, it is useful to adopt the theoretical framework for the analysis of authenticity proposed by Coupland $(2003,2014)$. One of the core attributes of authenticity, according to Coupland, is historicity (see also Section 2.3). The Vondelianists discussed in 5.3.1 were near-contemporaries of Vondel himself, who only died in 1679 at the age of 91 . Hooft passed away in 1647, when he was 66 years old. Vollenhove and Brandt were in contact with Vondel, and constituted 
the bridge to the next generation of Moonen, van Hoogstraten, Nylöe and so on. However, the ongoing transmission of language norms founded on the writings of seventeenth-century authors such as Hooft and Vondel in the eighteenth century led to a situation around 1800 in which many of the language experts were born about a century after Vondel's death. Moreover, in the first half of the nineteenth century, the literary highlights of the first half of the seventeenth century were two hundred years back in time. This did not exclude the possibility of identification with the language and the authors of the Golden Age, quite the contrary, but it did mean that the normative point of reference had undeniably become a historical point of reference, as a result of which language change became topical.

Other important attributes of authenticity are ontology and systemic coherence (Coupland 2003). I will analyse their relevance in a discussion of what could be called the contemporary communally shared story about the form and function of the Dutch language, viz. the first history of the Dutch language published as an independent volume (van Rossem 1994: 191). The book was written by Annaeus Ypeij, and it came out in 1812 under the title Beknopte geschiedenis der Nederlandsche tale ('Concise history of the Dutch language'). A second volume comprising additions and corrections was published in 1832.

In 1807, Ypeij had already published a book about the meaning of obsolete and unfamiliar words in the official translation of the Bible, the so-called Statenbijbel of 1637. A second volume, co-authored with W. C. Ackersdijck was published in 1811. The Statenbijbel was another normative point of reference, in addition to the literary works of Vondel and Hooft. In the early eighteenth century, when Vondelianism was dominant, Verwer (1707) had strongly advocated the linguistic purity of the 1637 Bible translation. In 1710, van Hoogstraten reconciled the Vondelianist perspective with Verwer's, arguing that both the best literary authors of the Golden Age as well as the Bible translation were perfect examples of regular use of grammatical gender.

Ypeij was a minister, a professor of theology at the University of Groningen, and the author of several works about the history of Protestantism. To him, the rise of Protestantism was an important aspect of the Dutch Golden Age (see below). Ypeij (1807) and Ypeij \& Ackersdijck (1811) were clear indications of the lexical differences between seventeenth-century and nineteenth-century Dutch, thus acknowledging that the language had meanwhile changed. In other words, early seventeenth-century Dutch had become historical.

The perceived historicity of the early seventeenth century did not prevent Ypeij from conceptualising the period as the undeniable climax of the development of Dutch. A first important observation about his history of the language is that it was not historical in the sense of, for example, ten Kate (1723) or the works of his contemporaries Jakob Grimm and Rasmus Rask. Ypeij did not focus on internal 
developments of the linguistic system and their trajectory through time. Instead, his history of Dutch was very much a history of Dutch as a literary language. He presupposed the inherent connection between literary and linguistic quality, which implied that the best literary authors were also the best language users, which was, in turn, one of the reasons to consider them the best authors. As such, Ypeij worked entirely within the good usage framework (Ayres-Bennett \& Seijido 2013).

This is also reflected in the developmental stages in Ypeij's chronology of the Dutch language. These were, in many respects, similar to the chronologies of van Hoogstraten and Verwer (see 5.3.1). The renewed purity found in seventeenthcentury sources identified the period as a Golden Age in which the language revealed itself in an authentic form, that is, when the Dutch language was truly itself. This is the ontological side of claims to authenticity. "Authentic things", as Coupland (2003: 418) says, "somehow carry their existence within themselves. They have an intrinsic claim to existence; they exist in essence". Obvious examples are "standard varieties ideologised metonymically as 'the language" (Coupland 2003: 420). When Ypeij touched upon the language of the seventeenth century, he singled out two familiar literary authors, claiming that

in den stijl van Hooft en v.d. Vondel treffen wij reeds de taal zoo gevormd aan, als zij thans is, en over het geheel genomen, zoo zuiver, als zij naar het oordeel van den tegenwoordigen kenner derzelve behoort te zijn.

(Ypeij 1812: 474)

in the style of Hooft and Vondel, we already find the language as it is today, and overall, as pure as it should be according to present-day experts.

The quotation shows an intriguing act of identification: the early nineteenth-century language expert was able to determine the purity of Dutch, and located this purity in the historical stage of the seventeenth century. Contemporary criteria for purity, in other words, were already met by seventeenth-century authors such as Hooft and Vondel, thus establishing a homogeneous and diachronically invariable form of the language. While Ypeij acknowledged the lexical changes that made the 1637 Bible translation sometimes difficult to interpret, he also considered the nineteenth century to be part of the same sixth and final developmental stage of the Dutch language, which ran from the times of Hooft and Vondel to the present day (Ypeij 1812: 428). The Golden Age was a historical anchoring point. At the same time, however, it constituted the essential developmental stage of the Dutch language which extended into Ypeij's days, and which therefore remained within reach. The Golden Age was a historical moment that could be revived.

This is an important difference with an even earlier period when Dutch language and literature reached a high degree of purity. Ypeij's (1812: 312-374) fourth developmental stage ran from the middle of the thirteenth century to the end of the fifteenth century, recalling Verwer's and van Hoogstraten's chronology (see 5.3.1). 
Ypeij also celebrated the works of thirteenth-century authors Jacob van Maerlant and Melis Stoke, and exclaimed Hoe grammatikaal zuiver is deze oude taal! 'How grammatically pure this old language is' (Ypeij 1812: 332). The adjective oud 'old' reveals that the thirteenth century was a historical moment beyond reach, which could not be revived. In addition, the language of Maerlant and Stoke was localisable (Ypeij 1812: 321). Maerlant wrote Flemish and Stoke wrote Bataafsch 'Batavian', that is, Hollandic, implying that they used a regional variety instead of the Dutch language itself.

The view of the thirteenth century as more historical than the seventeenth century, not just in terms of temporal distance but also perceptually, and as a period of various co-existing regional languages instead of one national language relates to another attribute of authenticity, viz. systemic coherence. Authentic things are part of "significant contexts", reflecting a relevant "set of relations", and they gain their authenticity within specific social or cultural matrices (Coupland 2003: 419). Authenticity is produced within a larger system of interdependent notions. In the historical Dutch case, this means that the authenticity of the language of the Golden Age was part of a broader narrative of the rise of the Dutch nation in the seventeenth century. The intellectual background to this was the intrinsic relationship between language and nation developed in eighteenth-century Enlightenment discourse (see Chapter 2), and endorsed by Ypeij in the introduction to his history of Dutch:

Immers blijkens de geschiedenis van vroeger en later volken [...] wordt de bijzondere taal van elk volk steeds gewijzigd naar deszelfs karakter, naar deszelfs voor of achter uit gaan in zedelijkheid, in verlichting en beschaving. Naar gelang hierin een volk achterlijk toont te zijn, ziet men, dat ook deszelfs taal min gepolijst, ongevormd en ruw is. En, omgekeerd, begint een volk hierin reeds eenige merkbare voortgangen te maken, zoo krijgt ook even daardoor allengs de taal een beter voorkomen.

(Ypeij 1812: 5)

After all, the history of older and more recent nations shows that the specific language of each nation is modeled after its character, its progress or regress in morals, Enlightenment and culture. If a nation is backward in these respects, one sees that its language is less polished, ill-formed and coarse. And, conversely, if a nation begins to make noticeable progress in these matters, its language also acquires a better appearance.

Ypeij (1812: 6) wrote his history of Dutch in accordance with this insight, meaning that his history of the Dutch language simultaneously told the history of the Dutch people. But Ypeij not only adopted the co-evolution of language and nation as a leading principle for his book. He radicalised this view by claiming that language was perhaps the most important characteristic of a people: a nation that adopts another language, wordt een gansch ander volk 'becomes a completely different nation' (Ypeij 1812: 14). 
Ypeij's (1812: 428-573) chapter about the sixth and final stage in the development of Dutch, running from the times of Hooft and Vondel to his own days, is completely in line with this approach. The chapter begins with a detailed description of the great revolutions that occurred in the Netherlands in the sixteenth and seventeenth centuries: a political revolution that led to the independence of the northern Netherlands, freed from the Spanish reign, and the religious revolution of Protestantism (Ypeij 1812: 428-429). After having discussed Luther and Calvin, he switches to a discussion of the Revolt against the Spanish/Habsburg rule, and concludes that these decisive changes in politics and religion had great consequences for the arts and sciences (1812: 436-437). He then discusses the economic success of the northern Low Countries and also mentions the revived interest in Latin and Greek texts (1812: 438-440). An overview of the international canon of Dante, Petrarch, Ronsard, Donne and Opitz then leads to an elaborate discussion of the exceptional merits of Hooft (1812: 442-461). In passing, he briefly refers to other Dutch poets of the period, and then moves on to discuss Vondel (1812: 464-474). Ypeij's interpretation of the Golden Age poets as representing the point de la perfection is embedded in a larger framework in which the Dutch nation became politically independent, and thus an authentic nation-state, in which Protestantism replaced Catholicism, unprecedented wealth was attained, and an equally extraordinary high level of cultural success was reached. Language, in Ypeij's approach, is symbiotically connected not only to literature, but also to politics, economy, religion and culture. In other words, Ypeij tells the familiar nineteenth-century story of the Dutch Golden Age, with a focus on language. In the Golden Age, the Dutch nation became its authentic self, in politics and religion, and in language too. ${ }^{3}$

As with Verwer and van Hoogstraten (5.3.1), Ypeij's national narrative of the glory of the Dutch language in the seventeenth century is closely connected to social upheaval and foreign reign. The period in between the thirteenth century and the Golden Age is the fifth developmental stage in Ypeij's chronology (1812: 375-427), and while he praises some authors from this period and also mentions the invention of printing as a positive development, he is generally very critical of this period of Frenchification, wantaal 'de-language' and ontaal 'un-language' (1812: 398-399). Similarly to van Hoogstraten, Ypeij is also highly critical of most of the authors that came after Hooft and Vondel (1812: 503). Outside the small circle of Vondelianists, a zwaren nevel 'thick fog' can be discerned in the literary field. It is only from c. 1750

3. It goes without saying that the federalistic political constellation of the Early Modern Republic of the Seven United Provinces was quite different from the modern nation-state called the Kingdom of the Netherlands (Israel 1996; van Sas 2004). Also, a large minority of the Dutch people, up until the present day, are of Catholic descent. In 1809, 38\% of the Dutch people were considered Catholics (Knippenberg 1992). One well-known seventeenth-century Catholic is Vondel. 
onwards that the new period of progress began (Ypeij 1812: 543). Here, Ypeij refers to the debates on language and literature that dominated Dutch Enlightenment discourse in the second half of the eighteenth century, particularly in societies such as the Maatschappij der Nederlandsche Letterkunde ('Society of Dutch Language and Literature'), to which he dedicated his history of Dutch.

The glorious rise of the Dutch nation and the concomitant perfection of the Dutch language are in Ypeij's interpretation situated in the Protestant north, specifically in seventeenth-century Holland. Here, his view resonates with the recently described myths dominating the history of Dutch in the southern Low Countries (Section 5.2). Ypeij embraces the idea that the Dutch language in the southern Netherlands suffered from extreme decay and dialectisation, and he locates these developments much further back in time than the eighteenth century. As early as the fifteenth century, when the north also entered a period of regress, the Flemish language in the south fell into decay, and until the present day lives in dezelfde laagte, waarin het voor meer dan twee eeuwen gezonken is 'in the same dip, into which it sank more than two centuries ago' (Ypeij 1812: 322). When the north freed itself from foreign rule, the southern Netherlands remained under Spanish rule, the meest verlichte gedeelte 'most enlightened part' of its population fled to the north, and the southern regions were destroyed, lacked any economic activity, noblemen turned into beggars, villages were deserted and taken over by wild animals, and wolves tore apart those who crept to the fields to cut the weeds that they fed on (Ypeij 1812: 437-438). Adopting the same scheme of interrelated notions as in the northern Dutch case, Ypeij argues that the decay of Dutch in the southern Low Countries is intimately connected to the political and economic situation. Immediately following his vivid description of the deplorable south is his analysis of the north:

Geheel het tegendeel had plaats in de zeven verëenigde gewesten. Landbouw, handwerk, koopmanschap, zeevaart, alles bloeide daar. De hoorn des overvloeds werd er allerwege uitgestort. Overvloed van alles droop als langs de straten.

(Ypeij 1812: 438-439)

Completely the opposite took place in the seven united provinces. Agriculture, arts and crafts, trade, shipping: everything flourished there. The horn of plenty was poured everywhere. Abundance of everything almost flowed down the streets.

The northern wealth is subsequently linked to the development of the language in the works of Hooft and Vondel. A crucial fact in this interpretation is that the assumed perfection of the literary register depended on its grammatical regularity: in the works of Vondel and Hooft, as Ypeij said, the language was already found as it was in Ypeij's days, that is, regularised, uniform, normalised. Ypeij confidently embraced the idea of northern uniformity as well as its homogeneity through time. 


\section{Official support for the Golden Age Myth}

The Golden Age continued to be the prime normative point of reference in early nineteenth-century metalinguistic discourse. Important metalinguistic texts were produced by the first academic professors of Dutch. From 1815 onwards, when the United Kingdom of the Netherlands was established, a range of new professors inaugurated in cities in the southern and northern Netherlands as part of the socio-cultural policy of the new state; see Chapter 8 , where other predecessors such as Siegenbeek will be discussed. Many of these official language experts contributed strongly to the national myth of the Golden Age.

When in 1817 the northern Dutch Catholic J. M. Schrant was made professor of Dutch in the southern city of Ghent in the context of the national language policy of King William I (Weijermars 2009), his inaugural address discussed the value of the study of Dutch. He presented an overview of the history of the language, in which he referred to predecessors such as Siegenbeek and Ypeij (Schrant 1818: 13-14). Working within the good usage framework, Schrant's history of Dutch was essentially a history of Dutch literature, including rhetoric, linguistics and the writing of history. His overview of laudable authors began with Vondel, Hooft and a few other seventeenth-century poets, continued with eighteenth-century writers such as the Vondelianists (Section 5.3.1), and ended with contemporaries such as Weiland and Siegenbeek (Schrant 1818: 30-46). Like Ypeij, Schrant considered the period from Vondel and Hooft until his own days as one developmental stage in the history of Dutch, in which the earliest sources, dating back to the first half of the seventeenth century, already comprised the Dutch language as it should be. Literary authors or works from before the Golden Age were not mentioned at all, except when Schrant explicitly addressed his southern Dutch audience and referred to laudable literary and linguistic works from the south, such as those of the thirteenth-century poet Maerlant (Schrant 1818: 47). After having acknowledged these southern highlights, Schrant (1818: 48-49) argued for a common policy to reunite southern and northern language practices, in line with the official policy at the time of the United Kingdom of the Netherlands, which, however, largely came down to promoting northern authors such as Hooft, Siegenbeek and Weiland.

In 1819, Schrant's colleague Lulofs at the University of Groningen published a history of the Dutch language, which began with a broad overview of the (pre-) history of the Germanic languages, as Ypeij (1812: 7-115) had also done, whose story in fact started with the Biblical flood. Authors working with such great timespans obviously could not escape the observable fact of language change, and both Ypeij, who Lulofs (1819: 104) mentioned, and Lulofs described the history of the Germanic languages in historical terms. This means that they readily acknowledged both the regional and the diachronic variability of all Germanic languages, as well as the fact that distinctly Dutch sources only date back to the High Middle Ages (e.g. Lulofs 
1819: 105-107). Lulofs also incorporated an elaborate chapter on the influence of neighbouring languages such as Frisian, Saxon and French as well as Latin on the development of Dutch (Lulofs 1819: 108-145). But historical in the case of Ypeij and Lulofs did not refer to the principled ever-changing grammar of any language, but to the gradual evolution of the Dutch language towards a state of perfect uniformity and homogeneity, to a state that revealed the language as it actually was.

For Lulofs, too, this normative point of reference was the Golden Age, as he explained in his inaugural address of 1815, which carried the revealing title Inwijdingsredevoering over de noodzakelijkheid van de beoefening der eigene taal en letterkunde voor de zelfstandigheid en den roem van eene natie ('Inaugural address about the necessity of the study of its own language and literature for the independence and the fame of a nation', see also Petiet 2018). Like Ypeij, Lulofs (1815: 4) adopted the Leitmotiv that the developmental state of a nation in political and economic terms coincided with its level of literary and linguistic cultivation. In the Dutch case, this historical moment was found a century and a half or two centuries ago, that is, in the seventeenth century, when the Dutch nation was an independent superpower, freed from the Spanish rule, and extremely wealthy (Lulofs 1815: 7, 18-19). At the same time, the Dutch national character became more apparent than ever before (Lulofs 1815: 21). The political, economic and ethnological uniqueness of the period also boosted the study of the national language and literature (Lulofs 1815: 21). The symbiotic unity of perfect literature and perfect grammar characterising the good usage approach was most visible in the works of Hooft and Vondel (Lulofs 1815: 31).

In 1816, J. P. van Capelle became professor of Dutch at the university of Amsterdam. In his inaugural address, he discussed the contribution of Amsterdam in the history of Dutch language and literature, which resulted in an entirely traditional narrative as most of the authors hailed, such as Hooft and Vondel, spent long periods in the city of Amsterdam. After having recalled the original purity of Maerlant and Stoke in the thirteenth century, van Capelle described the fourteenth, fifteenth and sixteenth centuries in terms of decay and Frenchification (1816: 6-10). From the sixteenth century onwards, a handful of fine authors, such as Coornhert and Spiegel, advanced the Dutch language, which however still led to onze letterkunde 'our literature' being in den staat der kindschheid 'in the state of infancy' (van Capelle 1816: 16). But then, a gewigtige omkeering 'important revolution' occurred in kerk en staat 'in the church and in the state', and religious freedom of thought was established along with political independence (van Capelle 1816: 16). In addition, trade stortte zijnen overvloed uit 'poured its abundance' (van Capelle 1816: 16). The political, religious and economic uniqueness subsequently led to the birth of a true Dutch literature, exemplified first and foremost by the works of Hooft and Vondel (van Capelle 1816: 35). 
Finally, G. J. Meijer in his inaugural address at the University of Louvain in 1822 discussed the study of the Dutch language as the best means to the advancement of true patriotism. He, too, adopted the inherent relationship of language and nation, and he, too, adhered to the radical interpretation, which said that [s]lechts door eene eigene taal zijn wij een eigen en afzonderlijk volk 'only through our own language are we a unique and separate nation' (Meijer 1822: 5). This onwraakbare waarheid 'irrejectable truth' (Meijer 1822:5) implied that the development of the national character went hand in hand with the cultivation of the language (1822: 6). Passing over a full history of the Dutch language, which can be found in Ypeij (Meijer 1822: 8), the end point of Meijer's argument turned out to be that the best Dutch authors were Hooft and Vondel, after the two early predecessors Maerlant and Stoke (Meijer 1822: 13).

\section{The Golden Age and language change}

The poets of the Golden Age used an authentic form of Dutch that revealed the language as it actually was. Their language thus constituted a normative point of reference in the first half of the nineteenth century. At that point in time, however, the Golden Age was almost two centuries back in history, which raised the topic of language change. Language change, in its turn, raised the issues of continuity and homogeneity.

As was mentioned above, linguistic changes that had occurred in the meantime were often readily acknowledged. Ypeij (1807) and Ypeij \& Ackersdijck (1811), while working with the myth of the seventeenth century as a Golden Age of the Dutch language, indicated lexical changes and ambiguities that complicated the interpretation of the official Bible translation (1637). A similar project, carried out by members of the so-called Royal Institute, led to the publication of a Uitlegkundig woordenboek op de werken van Pieter Korneliszoon Hooft ('Explanatory dictionary of the works of Pieter Cornelisz. Hooft', 1825-1838). One of the goals of this project was to revive vocabulary that had become obsolete between Hooft's times and the nineteenth century, that is, to reverse language change (Uitlegkundig woordenboek 1825: XI). Among the collaborators were Siegenbeek and van Capelle (Uitlegkundig woordenboek 1825: XIII; see also Section 7.5).

Changes in orthographical conventions were also acknowledged. For example, with regard to many of the well-known controversial issues in seventeenth- and eighteenth-century metalinguistic discourse (van de Bilt 2009: 173), the choices codified by Siegenbeek (1804a) differed remarkably from the preferences of Vondel. Among the first concrete spelling issues that Siegenbeek (1804a) discussed were the representation of Wgm. $i$, of long $a$ 's, and of etymologically different $e$ 's and $o$ 's.

For long $a$ in closed syllables, Vondel used <ae $>$, as in waer 'true' and zwaert 'sword'. This was a common grapheme in the seventeenth century, which was 
also adopted by Vondelianists such as van Hoogstraten and Moonen (van de Bilt 2009: 193; Vosters, Rutten \& van der Wal 2010: 101). Siegenbeek prescribed <aa>, a grapheme that Hooft had also used. Despite the Vondelianist preference for $<$ ae $>$, writing practices evolved from predominantly $<$ ae $>$ to predominantly $<$ aa $>$ in the course of the seventeenth and eighteenth centuries (cf. Vosters, Rutten \& van der Wal 2010: 104). When in the 1760s and 1770s Adriaan Kluit published his essays on spelling that would become very influential, he adopted $<$ aa $>$ (van de Bilt 2009: 193). Siegenbeek based his prescriptions on Kluit's (van de Bilt 2009: 206210), while devoting seventeen pages of his official spelling regulation to this topic, whereby he also discussed the discrepancy between Hooft and Vondel (Siegenbeek 1804a: 81-97).

Another topic was the representation of etymologically different long $e$ 's and $o$ 's in open syllables, which either developed through lengthening of short vowels in open syllables or through monophthongisation of West Germanic diphthongs. Vondel used a spelling system that was founded on morphological principles. Siegenbeek, however, codified an etymology-based system, which was hardly found in contemporary northern Dutch sources, but which dated back to sixteenth century southern writing practices. ${ }^{4}$ Siegenbeek (1804a: 97-136) devoted about forty pages to the spelling of vowels in open syllables, where the different $e$ 's and $o$ 's constituted the main point of controversy. Likewise, for diphthongised [عi] out of West Germanic $i$, Vondel and many Vondelianists preferred $<\mathrm{y}>$ (Vosters, Rutten $\&$ van der Wal 2010: 101). Siegenbeek prescribed $<\mathrm{ij}>$, which he explained in a discussion of almost twenty pages (1804a: 63-81).

What is important about these examples is not only that Siegenbeek's (1804a) choices differed from Vondel's, but also that there was variation in the Golden Age itself. In the case of $<$ ae $>$ and $<$ aa $>$, for example, Hooft and Vondel preferred different variants. Furthermore, $<y>$ and $<\mathrm{ij}>$ had been competing variants for a long time, and various writing practices existed for the representation of the different $e$ 's and $o$ 's in open syllables (Rutten \& van der Wal 2014: 34-35). Moreover, Hooft and Vondel were not consistent throughout their lifetimes, particularly with respect to morphosyntactic features, so that variation also existed within single authors. For example, both are known to have switched towards an almost exclusive use of single negation (Rutten et al. 2012:327), and Hooft consciously adopted the specialised third person reflexive pronoun zich (van der Wal \& van Bree 2008: 215).

The discrepancy between the Golden Age as a supposedly uniform model and Siegenbeek's choices ties in with Lippi-Green's (1997) analysis of SLI in the present.

4. For more background to the different $e$ 's and $o$ 's and the various writing systems in use, see Rutten \& van der Wal (2013: 104-105), and see Chapter 11 for the use of long e's in contemporary sources. 
An important characteristic of SLI is the discrepancy between the claimed model of the standard on the one hand, and the actual source on the other. Nowadays, the claimed model is the written language, that is, a variety that is assumed not to be tied to any specific social group - an anonymous variety - that is accessible to everyone. However, the actual source is the spoken language of the upper middle class. A similar discrepancy can be found in history. Authors such as Siegenbeek (see Chapter 8) celebrated the seventeenth century as the Golden Age of the Dutch language, while their prescriptions were often founded on the normalised language of the late eighteenth and early nineteenth centuries.

In morphology, similar discrepancies can be found. In seventeenth-century Dutch, for example, the diminutive suffix -ken was still common in the written language, and was also in use by Vondel and Hooft. Weiland (1805: 51-52) prescribed the palatalised, more recent variant -je, while only mentioning -ken as a historical variant. He also referred to his Dutch dictionary s.v. je, but the discussion there was similar and mainly provided a few more examples (Weiland 1803: 342-343). Admittedly, Weiland's (1805a) grammar comprised for the largest part concrete grammatical rules and discussions, while the Golden Age discourse was absent from this particular text, which also hardly referred to Vondel and Hooft. In the introduction, Weiland did adopt the familiar view of the language as an authentic expression of the essence of the people, in line with the international tradition of Condillac, Herder, and Michaelis (Noordegraaf 2018; see also Chapter 2). Moreover, according to Noordegraaf (2018), the usus constituted a crucial aspect of Weiland's concept of the national language, particularly the usus of the boni autores. Who, then, were the good authors?

There can be no doubt that for Weiland, too, the seventeenth-century poets and the subsequent tradition of Vondelianism were the ultimate normative points of reference. This is obvious from Weiland's discussion of important topics in grammar such as gender and case. Despite his claim that the number of nominal cases in a particular language depends on the number of formal modifications that nouns can undergo (Weiland 1805a: 72), and despite the fact that nominal case was hardly a living category in eighteenth- and nineteenth-century Dutch, Weiland (1805a: 74) proposed a full four-case system of nominative, genitive, dative and accusative. In Section 4.5, I have argued that his prescriptions for the genitive and the dative, and his emphasis on synthetic forms constituted a return to the norms of the first generation of Vondelianists in the early eighteenth century. Similarly, van de Bilt (2009: 157-159) has shown that Weiland's (1805a) discussion of grammatical gender depended strongly on the works of Kluit, in particular on the introduction to Kluit's 1783 edition of van Hoogstraten's list of nouns (see Section 5.3.1). Most of Kluit's rules to determine the gender of nouns could already be found in the works 
of early eighteenth-century Vondelianists such as van Hoogstraten and Moonen (van de Bilt 2009: 147-153). ${ }^{5}$

With respect to case and gender, there was an immediate connection from Weiland back into history, and no mention of intermediate language change. Homogeneity was observable in the stability of linguistic prescriptions and practices. In many other cases, changes between the seventeenth and the nineteenth centuries were readily acknowledged by nineteenth-century adherents to the Golden Age Myth, without, however, challenging the myth itself. At the ideological level, homogeneity, constructed through a discourse of authenticity, was maintained. This shows that myth building is primarily a discursive operation with a culturally and sociopolitically identitary function. Put differently, the attested fact that seventeenth-century Dutch was in many respects different from nineteenth-century Dutch did not affect the idea that the language of the Golden Age was authentic Dutch and the 'best' language in a meaningful sense of the word. This idea was intimately connected to that of the Dutch nation acquiring simultaneously independence, wealth and Protestantism.

\subsubsection{The Golden Age continues}

The nineteenth-century texts discussed in 5.3.2 form a cocktail of cultural and political ingredients that make up the Dutch Golden Age, one of which is language. Arguments about the rise of the national language ran parallel to discussions of economic success, political integration, the rise of the nation, the rise of Protestantism and the Golden Age of literature and art. As to language, two types of Golden Age adoration can be discerned. The first type claimed the immediate continuity from the Golden Age to the present: the language was principally the same. For some grammatical features, such as case and gender, this position could actually be maintained. What was more usual was the second type of Golden Age adoration, whereby the similarity between seventeenth-century Dutch and more recent periods was discussed in terms of style and purity. This is the view that underpinned the many opaque references to the language of the Golden Age as the prime example of the Dutch language as it actually was or should be. It can also be found, for example, in Siegenbeek's (1826) history of Dutch literature. The second type did not claim that the language had remained exactly similar, but instead, that the Golden Age provided the best Dutch, to which later language users should turn for guidance.

5. An important difference was Kluit's much more tolerant treatment of sources predating the Golden Age (van de Bilt 2009: 139-142). 
Whichever of the two types of Golden Age adoration was adopted, the underlying ideology was one of homogeneity. The presumed homogeneity applied to the one Dutch language, created in the Golden Age, which functioned as an iconic representation of the one Dutch nation. Even if there were concrete differences, as the spelling issues referred to above, the language was principally the same, and its purest and stylistically supreme form could be found in the literary sources of the Golden Age. This, then, should be the model for nineteenth-century Dutchmen, and it should therefore be taught in schools, as argued, among others, by Siegenbeek (1810b).

The Golden Age discourse was maintained throughout the nineteenth century. Verdam (1890: 33) said that the main difference between the medieval period and the post-medieval period was principally not of a linguistic nature, but of a cultural/historical and literary kind. The post-medieval period saw the rise of the Dutch nation-state and this led to the establishment of the national written language (Verdam 1890: 41). The Dutch revolt of the late sixteenth century led to unprecedented geestkracht en kloekheid 'strength of mind and sturdiness', particularly in Holland, the richest and most powerful of the Dutch provinces, the home of the Dutch Renaissance and the rise of a new literature, where a new literary and official language were invented, which would become the national written language (Verdam 1890: 54-55). Here, language standardisation is but one part of a larger explicitly Hollandocentric - history of the heroic rise of the Dutch nation.

In 1882, the first volume of the Woordenboek der Nederlandsche Taal ('Dictionary of the Dutch Language') was published, one of the great projects of nineteenth-century linguistic nationalism (de Vries 1882: XXXVIII; see also Chapter 7). In the introduction, the founder of the project, Matthias de Vries, explained the periodisation used. It was meant to be a dictionary of contemporary Dutch with a historical outlook. The terminus a quo would be the bloeitijd 'bloom, Golden Age' of Dutch literature from c. 1580 to c. 1640, which had been very important for onze nationale ontwikkeling, ook uit een taalkundig oogpunt 'our national development, also from a linguistic point of view' (de Vries 1882: XL). In a similar line of reasoning, van Helten's (1881) study of the language of Vondel, and Heinsius's (1897) study of the language of the official Bible translation (1637) refer to the enormous influence these texts had exerted on the development of the standard variety. Te Winkel (1901:27) claimed that the seventeenth century witnessed ever more uniformity and that vrijwel dezelfde taal 'practically the same language' was written everywhere in the eighteenth century. He added that grammarians created unity and regularity in the language, changing it into a supraregional variety (te Winkel 1901: 28). 
Te Winkel's claim resembles the position that is usually taken in more recent histories of Dutch, where it is no longer claimed that the language of the seventeenth century is principally the same as the present-day standard variety. However, the discourse has still remained similar to a very large extent. When discussing the Golden Age as a period of linguistic purification, authors such as Ypeij (1812) and Siegenbeek (1826) referred to the well-known language purification activities of the Golden Age, which included the expulsion of loans, the introduction of neologisms, the regularisation of spelling and grammar, in short, to seventeenth-century metalanguage. Dutch language planning took off in the sixteenth century, and corpus planning involves choosing between alternatives. This means that codification and selection, to use Haugen's (1966) well-known terminology, can be traced back to this period. The idea that this period therefore constitutes "the first phase of the standardization process" (van der Wal \& van Bree 2008: 220; my translation) is ubiquitous in histories of Dutch (Janssens \& Marynissen 2008: 118-127; van den Toorn et al. 1997: 377; van der Wal 1995a: 101). The most extreme case in point is probably van der Sijs (2004), whose central thesis is that the present-day standard variety was consciously constructed in the sixteenth and seventeenth centuries, and spread over the language community in subsequent periods.

All histories of Dutch mentioned so far discuss the alleged standardisation in the sixteenth and seventeenth centuries almost exclusively with reference to codification and selection. Their influence on actual language use, however, has "only occasionally" been studied, as van der Wal (1995a: 73; my translation) acknowledges, and would "require an extensive investigation of language use that is representative of various groups [of speakers] in contemporary society". It should be noted that in these histories of Dutch, selection is conceptualised as a conscious action taken by influential language users such as grammarians and literary authors. It does not usually refer to the outcome of focusing and leveling between speakers and writers of different variants and varieties in contact. Studies such as Anderwald (2016) and Rutten, Vosters \& Vandenbussche (2014) leave little room for convincing effects of normative metalanguage on actual language practices.

In post-Haugen vocabulary, Early Modern metalanguage is discussed in terms of codification and selection, and it is often attributed great importance with respect to the standardisation of Dutch. Linguistic terminology may have changed, but the main claim is very similar to the Golden Age discourse discussed above, viz. that seventeenth-century metalinguistic discourse was crucial in the formation of the Dutch standard variety. 


\subsection{Final remarks}

In this chapter and the next, I focus on two language myths that characterise the Dutch situation in the decades around 1800. One of these is the Golden Age Myth: a foundational myth that provides a story about the origin and evolution of the national language, and that locates the authentic essence of the language of the Dutch people in the first half of the seventeenth century. The Golden Age Myth implies a complex relation with history: the Golden Age is a historical period, 150 to 200 years back in time. Despite this temporal remoteness, however, the Golden Age can still be revived, which creates an immediate link to the nineteenth-century. The possible revival of Golden Age language practices ensures the homogeneity of the Dutch language through time.

The Golden Age Myth resonates with so-called Romantic or German models of nation building, and particularly, with the concept of authenticity. It is the discursive construction of seventeenth-century Dutch as an authentic and iconic representation of the Dutch nation that underpins the homogeneity implied by SLI, notwithstanding empirical evidence that identifies differences between seventeenth-century and nineteenth-century Dutch. The authenticity of seventeenth-century Dutch is given credibility and is backed up by the broader story that it is part of, viz. the story of the rise of the Dutch nation, which reached political independence and unprecedented wealth in the same period, while embracing Protestantism.

In Chapter 6, I discuss the Myth of Neutrality, which resonates with another string of concepts, viz. anonymity, rationalism, and French state formation. However, the Myth of Neutrality also employs a notion of authenticity. Ypeij's (1812) history of Dutch has played an important role in the present chapter, and it is a book in which the Golden Age Myth is carefully constructed on the basis of a wide range of historical sources and arguments. The final passage of the book runs as follows:

Geheel Holland trouwens was, na de spaansche beroerten, de voornaamste zetel der beschaafdheid geworden. In de overige gewesten bleef men hierïn meer ten achteren. Eerst gedurende de jongste vijftig jaren kwam aldaar te dezen aanzien eene aanmerkelijke verbetering. En door dezen weg is, zelfs ten platten lande, het onderscheid van dialekt der nederlanders, allerblijkbaarst verminderd. Bij het wel opgevoed gedeelte des volks is hetzelve altoos thans niet meer hinderlijk, waaröm het te hopen is, dat het gemeen, dit voorbeeld op den duur volgende, met den tijd, eene spraak zal leeren voeren, die gelijkvorming, en allen daar door niet onäangenaam is.

(Ypeij 1812: 573) 
The whole of Holland, by the way, had become the prime seat of politeness after the Spanish Troubles. The other provinces lagged behind in this respect. Only in the past fifty years has a noticeable improvement occurred in these areas. As a result, dialect differences between Dutchmen have clearly decreased, even in the countryside. Among the well-educated part of the nation, dialect differences are no longer disagreeable. Therefore, it is to be hoped that the common people will follow this example, and over time, will learn to speak a language that is uniform, and thus not unpleasant to all.

SLI and its core element of homogeneity prompt Ypeij to envision a recent process of variant reduction in the interest of linguistic neutrality, which is an important part of the Dutch interpretation of anonymity, as will be shown in Chapter 6. 



\section{CHAPTER 6}

\section{The Myth of Neutrality}

\subsection{Introduction}

Part of the discursive construction of Dutch as a national language was the incorporation of various language myths into the ideological framework of linguistic nationalism. The Golden Age Myth discussed in Chapter 5 represents the prototypically Romantic or German type of nation-state formation, and ties in with the concept of authenticity (Gal \& Woolard 2001, see also Section 5.2). In the present chapter, another language myth will be discussed that is typical of the Dutch situation, viz. the Myth of Neutrality. I will analyse the Myth of Neutrality as part of the rise of SLI in the Netherlands in the period around 1800. The Myth of Neutrality links up with discourses of anonymity (Gal \& Woolard 2001; Woolard 2016: 21-38), recalling the rationalist or French model of nation-state formation (Section 5.2). In such discourses of anonymity, specific language varieties are considered to be neutral communication tools, not linked to certain social or individual identities and, on the contrary, characterised by a sort of "aperspectival objectivity" (Gal \& Woolard 2001: 6). These varieties, often the standard varieties of widely used languages, are seen as important tools in processes of emancipation. There is a clear link with what is now often called the commodification of language (e.g. Cameron 2012). The concept of neutrality involved in this chapter, however, not only invokes the archetypical idea of anonymity, but also draws on a notion of authenticity.

In the present chapter, I will historicise the Myth of Neutrality by showing when and why it came into existence and what function it fulfilled in public and academic discourses on language. In 6.2, I will first discuss the importance of neutrality in the Dutch sociolinguistic make-up. Then, the concept of neutrality will be explored, whereby I will distinguish between two types of neutrality, and argue that the first type gave way to the second type in the crucial period around 1800 (Section 6.3). In Sections 6.4 and 6.5, I describe the two types in detail. 


\subsection{Neutrality in Dutch}

The idea of neutrality is notoriously important in Dutch linguistics. In 1924, the well-known linguist C. B. van Haeringen published a paper on "unity and differentiations in civilized-Dutch pronunciation", in which he discusses the question of what "phonetically pure cultivated Dutch" is (van Haeringen 1924: 65; my translation). Building on Jespersen's renowned definition of a standard language as "the language of those speakers by whose pronunciation one cannot hear from what district they come" (e.g. Jespersen 1925: 78), ${ }^{1}$ van Haeringen begins to answer the question by stating that a common language can only be a real unity, when it is impossible to determine the regional background of its speakers (van Haeringen 1924: 65). He admits that it is often quite easy to tell where a speaker of civilised Dutch comes from, but in a truly positivistic spirit, he predicts that the cleavage between this ideal and linguistic reality will disappear. The "process of levelling" is "irreversible" (van Haeringen 1924: 66; my translation). "The ideal of the future, or let me phrase that in a more neutral way: the end point, to which the development moves, is that those two are really identical, in other words that everybody who wants to speak in a civilised way, will deliberately strive to cure himself of everything dialectal" (van Haeringen 1924: 65-66; my translation). Needless to say, regionally and nationally conditioned phonetic variation still exists in standard Dutch and may even be increasing (e.g. Van de Velde et al. 2010).

Almost a century of linguistics and half a century of sociolinguistics later, very few linguists would still make such statements. Non-regionality, however, is a stronghold of lay definitions of standard languages, especially in the Netherlands and other western European language areas (Smakman 2012; cf. Esling 1999), and the myth of non-accent continues to be a core element of SLI in the United States (Lippi-Green 2012). Lippi-Green (2012: 60) emphasises the importance of having "no regional accent", adding that "[i]t seems that we want language to be geographically neutral, because we believe that this neutrality will bring with it a greater range of communication". The problem, of course, is that the supposedly neutral forms are easily localisable as Midwestern. A similar argument can be constructed with respect to Dutch, where the standard pronunciation is by and large recognisable as northwestern or Hollandic. Smakman (2012) investigated lay definitions of standard language in a mixed set of seven language areas including the Netherlands, Flemish Belgium, England, Poland, Japan, New Zealand and the United States. Bringing together all the different definitions, he concludes that "[w]ith the information so far, the definition of the standard language could be

1. Jespersen (1925: 70) quotes Henry Sweet's Sounds of English (1908), where a similar definition is given. 
that this language is the neutral communication tool within a country or speech community" (Smakman 2012: 54).

Present-day linguistic definitions of standard languages often make use of similar notions. The Algemene Nederlandse Spraakkunst or ANS ('General Dutch Grammar') offers a description of the grammar of standard Dutch. ${ }^{2}$ After having acknowledged the existence of many varieties of Dutch including dialects, sociolects and specialised languages, the ANS presents a tentative definition of standard Dutch as "the language in which no elements or structures occur that clearly stand out as non-general", and which can be used across the board in so-called secondary relationships, i.e. with strangers ( $E$-ANS, 0.6.2.1; my translation). Note that the ANS does not discuss phonology, but rather morphology and syntax. This means that the notion of neutrality is extended to include morphological and syntactic elements and is not limited to accent.

Referring to neutrality, Smakman offers a convenient way to generalise related concepts or criteria such as non-regionality, accentlessness and general applicability. It is clear, however, that the neutrality involved is a carefully constructed myth, as Smakman (2012: 54) adds that the standard language tends to be liked "although it may suffer from a degree of unnaturalness and colorlessness". Standard varieties are often considered distant or artificial, while local varieties may carry "strong notions of naturalness and straightforwardness" (Meyerhoff 2011: 41). The paradox about standard varieties is that they are often looked upon as unnatural, artificial, prestigious, distant, or even posh, while they are simultaneously surrounded by a discourse of neutrality. Smakman (2012: 36) shows that ideas about linguistic neutrality are particularly prevalent in England, Flanders and the Netherlands.

\subsection{Two types of neutrality}

Two types of neutrality should be distinguished. My argument will be that the first type was supplemented and often even eclipsed by the second type in the decades around 1800 . The first type I refer to as neutrality as a shared space. The second type is neutrality as unmarkedness.

In the case of neutrality as a shared space, linguistic forms or varieties are considered neutral in the sense that they are shared forms used for interdialectal

2. The first edition came out in 1984 (ed. by G. Geerts, W. Haeseryn, J. de Rooij \& M. C. van den Toorn), the second and strongly revised and expanded edition is from 1997 (ed. by W. Haeseryn, K. Romijn, G. Geerts, J. de Rooij \& M. C. van den Toorn). I used the 2002 online version, also called E-ANS, which is the electronic version of the 1997 edition. The E-ANS does not have page numbers, only section numbers. 
communication. There is little historical evidence of how this may have taken place in oral communication. In writing, however, it is clear from (western) European languages that supralocalisation has existed throughout history. Supralocalised forms are not neutral, as they have specific and distinct regional and/or social origins. However, they can come to be considered as shared forms by language users with very different regional and/or social backgrounds. In historical metalinguistic discourse, there is often widespread awareness that the forms have a particular background. The neutral or shared forms are regarded as additional forms, and the neutral variety as an additional variety for specific purposes. Salmons (2013: 264-265), discussing the history of German, stresses that the developing standard languages did not usually replace existing varieties, but merely added another layer to the sociolinguistic space. The neutral variety is often marked for use in specific registers such as sermons and literature. In some cases, deliberate koine constructions occur, for example in Bible translations where the aim is to reach the largest possible audience. Such koine constructions may involve erasure of regionally marked forms. They can also include the conscious and simultaneous use of forms from multiple regions. The former is an example of neutrality through erasure, depending on the salience of certain regional forms. The latter is an example of neutrality as patchwork.

Figure 1 presents a highly simplified visualisation of the most basic example of neutrality as a shared space, indicating regions $\mathrm{A}$ and $\mathrm{B}$ with varieties $\mathrm{A}$ and $\mathrm{B}$ respectively, which develop an additional variety, or rather a pool of forms that tend to co-occur in the case of communication between language users from regions $\mathrm{A}$ and $\mathrm{B}$. These forms are not necessarily drawn from either A or B - often one of the two will be dominant - as new forms may develop in contact situations (e.g. Kerswill 2002).

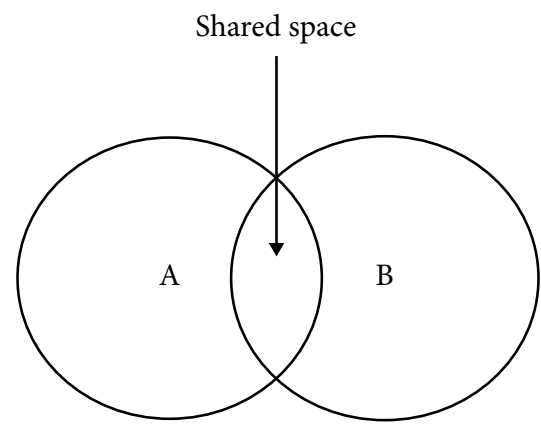

Figure 1. Neutrality as a shared space 
Neutrality as a shared space is historically present in many European language areas. Obviously, this type of neutrality is not neutral at all, but a discursive construction feeding on the direction of processes of supralocalisation. Its lack of neutrality becomes particularly apparent when it is combined with the ideology of the hierarchisation of varieties, when, in other words, a process of verticalisation (Mattheier 2003) takes place, according to which one variety is deemed better than other. In the same vein, Lippi-Green (2012: 66-71) talks about language subordination. Often, the supposedly neutral form or variety is considered better, in one way or another, than forms or varieties with a more restricted geographical or social span. Figure 2 presents the verticalised version of neutrality as a shared space. Despite the apparent hierarchisation of forms and varieties, a general awareness often remains that the supposedly neutral forms or varieties are but one layer of all linguistic practices in the language area.

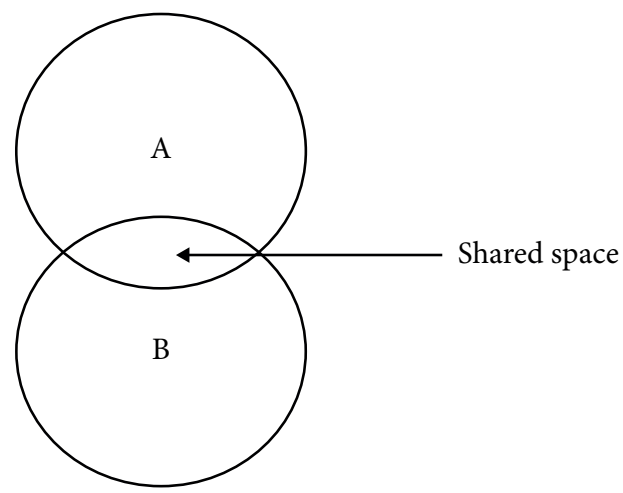

Figure 2. Neutrality as a shared space - 'verticalised'

It is in the decades around 1800 that neutrality as a shared space develops into the second type of neutrality as unmarkedness, a discursive move as a result of which the supralocalised forms are no longer just the forms that are marked for use in interdialectal communication. They lose their specific application and are constructed as unmarked instead. They become the forms that go unnoticed, the common forms, the standard options. By implication, other forms and varieties that were previously in use alongside the shared forms and varieties are now perceived as uncommon and non-standard, for which reason they should be avoided. Figure 3 visualises this discursive operation. A and B are erased from the discourse and lose their right to exist. In reality, they often continue to be used, and they are therefore placed between brackets (Figure $3 a$ ). Users of A and B are expected to orient to the supposedly unmarked centre, and they are ultimately expected to give up A and B. 


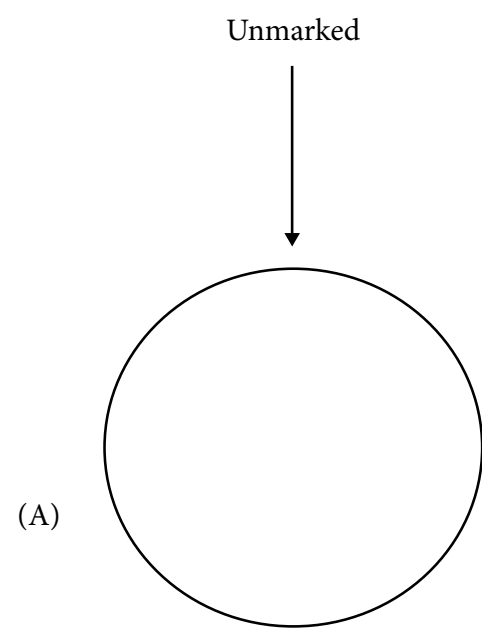

(B)

Figure 3a. Neutrality as unmarkedness

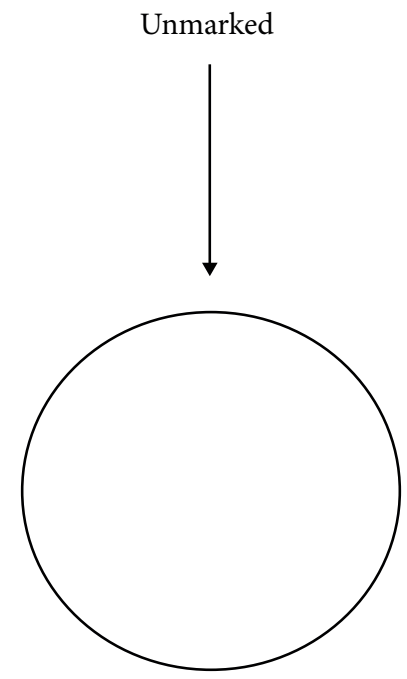

Figure 3b. Neutrality as unmarkedness (end goal)

Figure $3 \mathrm{~b}$ describes the desired end goal, with all language users being subsumed by and orienting themselves towards the so-called unmarked variety, and having lost their awareness of previously existing varieties.

Neutrality as a shared space historically precedes neutrality as unmarkedness, which has been the dominant type ever since it came into existence. The transformation into unmarkedness requires an intriguing, even paradoxical discursive 
operation. After all, it requires users of A and B to discard the forms characteristic of $\mathrm{A}$ and $\mathrm{B}$, and to adopt the view that the unmarked forms are not just additions to their verbal repertoires, but essentially the only forms that are suitable for communication. It requires them, in other words, to abandon the forms and varieties they are familiar with, to essentialise the standard variety, and to adopt the folk view of the linguistic system as outlined by Preston (i.a. 2002), according to which dialects are considered defective and degenerate varieties of The Language. In the following sections, I will argue that this metalinguistic tour de force eventually comes down to accepting that the language people have used from birth and have learnt from their parents (say A, or B), is not their actual mother tongue. Instead, their real mother tongue is the neutral variety, from which it follows that there are people who need explicit instruction in the mother tongue in primary and secondary education.

Here, it becomes clear how a discourse of anonymity can intersect with notions of authenticity. Whereas the argument is mainly centred around neutrality and anonymity, as will become clear in Section 6.5, it is simultaneously maintained that the neutral variety is also the true mother tongue of the members of the Dutch nation.

\subsection{Neutrality as a shared space}

To understand how a supralocal form of written Dutch became a supposedly neutral standard variety, the discursive changes in the concept of neutrality need to be historicised. The 'unmarked' form of neutrality that characterises the nationalist period, developed from an earlier period in which neutrality was mainly seen as a shared space' of supralocal forms. European languages have been subject to processes of supralocalisation since the Middle Ages (cf. e.g. Kloss 1952; Haugen 1966; Lodge 1993; Linn \& McLelland 2002; Deumert \& Vandenbussche 2003). Focusing on Dutch metalinguistic discourse from the sixteenth century to the early eighteenth century, I argue that in Late Medieval and Early Modern times, the supralocalisation of specific forms entails neutrality as a shared space. This does not mean that ideological notions such as the mother tongue, hierarchisation and linguistic polish, cultivation or perfection (Watts 2011: 134; Weber \& Horner 2012: 16-19) do not play a role. On the contrary, these are often applied to various forms and varieties and in particular to the allegedly neutral variety without, however, losing sight of its status as an addition to the already available repertoire. I also discuss the two kinds of conscious koine constructions referred to in Section 6.3, viz. neutrality as patchwork and neutrality through erasure. 


\subsubsection{From regionality to neutrality as patchwork}

The first metalinguistic works produced in the Low Countries date back to the sixteenth century. One of the earliest publications is Lambrecht (1550), in which the author argues for a phonetic spelling system, which he develops on the basis of his own Flemish pronunciation. Lambrecht explicitly states that he does not aim for a uniform orthography to be used throughout the language area (Dibbets 1977: 24). Instead, he argues that his phonetic spelling should be adopted throughout the language area, so that speakers from various regions will get to know each other's pronunciation. In practice, this means that people from Brabant and Flanders should write ja 'yes', whereas people from the region of Zeeland ought to write jae, reflecting their slightly more palatal pronunciation of this phoneme (Dibbets 1977: 24). The shared space developed by Lambrecht consists of orthographical principles that everybody can apply to their own pronunciation.

Other spelling guides from the same period are often less explicit about the aims with respect to the larger language area. Instead, they focus on the orthography of their own regional variety. Sexagius (1576) uses as the target variety of his orthographical description the Brabant dialects that he knew growing up and living in Brussels and Mechlin (van der Sijs 2004: 25). He does not aim for a uniform spelling for all varieties of Dutch.

The earliest Dutch orthographical texts were written in the 1530 s by someone called Varenbraken. The two manuscripts were never published and were only edited in the late twentieth century (Braekman 1978). Almost nothing is known about the author or the manuscripts, but it is clear from the language that they were produced in the southern parts of West Flanders or in French Flanders (Braekman 1978: 303). Like Sexagius' and Lambrecht's after him, Varenbraken's orthography is regionally marked and primarily meant for local/regional usage. Obviously, commentators such as Varenbraken, Lambrecht and Sexagius were aware of the fact that the Dutch language area is far greater than their home town and its surroundings. However, it is in the fullest awareness of the actual variety of Dutches that these commentators try to fix but one of these varieties. To the extent that their phonetic spelling systems are applicable to other varieties that make use of similar phoneme inventories, that is, to the extent that the spelling systems can be subject to supralocalisation, they engage in the construction of a neutral tool for written interdialectal communication.

In the same period, de Heuiter (1581) came out. He mentions earlier spelling books, such as Sexagius', aimed at regional spelling systems, while his own goal is to create a spelling for the whole language area (de Heuiter 1581:29-30, cf. Dibbets 1968: 174-176). De Heuiter had travelled a lot in the Low Countries: born and bred in the south of Holland (Delft, Leiden), he had spent time in Brabant 
(Mechlin, Brussels) and Flanders (Jabbeke near Bruges). For various reasons he criticises the spoken language in these regions as well as the varieties used in Zeeland and Guelders, but he also identifies the admirable aspects of all these varieties (de Heuiter 1581: 93-95; Dibbets 1968: 174-175). In trying to render Dutch as een gemeingelde Tale 'a mixed language', he claims that he has forged (gesmeet) his Dutch out of Brabantic, Flemish, Hollandic, Guelderish and Kleverlandish (de Heuiter 1581: 93). Dibbets (1968: 175-176) states that his orthography indeed incorporates elements typical of Holland, Brabant and Flanders, with perhaps a slight preference for Hollandic spellings. De Heuiter's reference to the ancient Greeks with their four languages, viz. "Ionica, Attica, Dorica, Aeölica, die vijfste noh daer uit gesmeet hebben / die zij nommen Gemeen tale", that is, 'Ionica, Attica, Dorica, Aeölica, and who have forged the fifth out of these, which they call common language' confirms his goal to create a neutral variety through patchwork.

Similar efforts to create neutrality as patchwork are found in translations from the Bible (van der Sijs 2004: 120-124). Both the 1556 translation by Utenhove and the so-called Deux-Aes Bible of 1561-1562 combine elements that are, in hindsight, considered to be Dutch and German, respectively. Utenhove, for example, uses datives in $-m$, such as am, dem, in allem, which are rare in the history of Dutch. The Deux-Aes Bible abounds with lexical items that sound markedly Low or High German rather than Dutch (e.g. gantsch ende gaer 'entirely'). Both translations were produced in the now German town of Emden in East Frisia, to which western Dutch Protestants had fled. This prompted the translators to create a patchwork of western and eastern continental West Germanic forms, but it also suggests that their concept of the Dutch and/or German language area(s) was perhaps quite different from the present.

\subsubsection{The mother tongue and hierarchisation}

The first fully-fledged grammar of Dutch is the anonymously published Twe-spraack vande Nederduitsche letterkunst ('Dialogue on Dutch grammar', 1584). As argued in 6.4.1, this period is characterised by regionally oriented metalinguistic texts as well as by texts in which a patchwork of forms is created to establish neutrality as a shared space. Particularly the patchwork of western and eastern variants suggests that authors are aware of the fact that their locality is part of a larger language area. But how large is this language area? Does it include the present-day Dutch and German countries? Discussing the concept of Dutch in the Twe-spraack, Dibbets (1985: 501-511) points out that the language area that the authors consider themselves part of stretches from Bruges in the southwest of the present-day Dutch language area to Riga in Latvia and even further to Tallinn in Estonia (Twe-spraack 
1584: 110). De Grauwe (2002) argues that this was a common way of thinking about continental West Germanic in Late Medieval and Early Modern times. The two main divisions in the linguistic landscape of Europe were 1. Germanic vs Romance, and 2. within Germanic, upper or high German vs lower German, where upper German refers to the southern varieties used in the south of present-day Germany and in Switzerland and Austria, and low German, sometimes also called Nederlands, refers to the area from Dunkirk in the north of France (which was largely neerlandophone well into the seventeenth century) to Tallinn. Reval, as the current capital of Estonia was often called, is usually considered the northernmost city of the Hansa, which explains the historical importance of Germanic varieties in the Baltic area generally.

These ideas about onze moeders taal 'our mother's tongue' (Twe-spraack 1584: $\mathrm{A} 2^{\mathrm{v}}$ ) and its place in Europe gain significance against the background of two fundamental linguistic hierarchies. The first is external and refers to the placement of Germanic varieties above Romance varieties, including Latin, and often also above Greek and Hebrew. The position was famously defended by Becanus in his Origines Antwerpianae of 1569, in which he claimed that Dutch was the original language, i.e. the language of paradise; the authors of the Twe-spraack explicitly referred to Becanus (Dibbets 1985: 502). The comparison with the mostly negatively evaluated Romance varieties remained very common in Dutch metalinguistic discourse of the seventeenth and eighteenth centuries (van der Wal 1995a: 43; Rutten 2006: 307-309). A popular argument for the superiority of Dutch was the abundance of monosyllabic words, an indication of its old age and originality (van der Wal 1995a: 48-52). The argument was picked up by Schottelius in his 1663 Ausfürliche Arbeit von der Teutschen HaubtSprache (van der Wal 1995b). Romance languages were said to have fewer monosyllabic words. Another argument was put forward by the grammarian van Geesdalle $\left(1700: 4^{*} 1^{\mathrm{r}}\right)$, who claimed that Dutch followed the order of thought, thereby appropriating the well-known argument about the ordre logique and the ordre naturel familiar from French metalinguistic discourse of the time (Swiggers 1984).

The broad concept of the mother tongue, spanning the present-day Dutch and Low German language areas as well as the Germanic varieties used in Poland and the Baltic area, was not a uniform and homogeneous block. The second, internal hierarchy addresses the relative prestige of the various varieties within the continental West Germanic area. According to the Twe-spraack, the best Germanic is found in Meissen (near Dresden), from where it was brought to the Low Countries. Here, the Twe-spraack relies on similar ideas expressed in German metalinguistic discourse, in which Saxon dialects have been idealised from at least the fifteenth century onwards (Dibbets 1985: 503). 
In the seventeenth century, the hierarchisation of varieties of Dutch remained topical, especially in the then very popular genre of farces. Well-known examples from the history of Dutch literature include Warenar (1617) by P. C. Hooft, the Spaansche Brabander Jerolimo (1618) by G. A. Bredero, and Trijntje Cornelis (1657) by Constantijn Huygens. In Warenar, Hooft uses linguistic means to characterise the Amsterdam characters. Bredero's play, which is set in Amsterdam, is about immigrants from Brabant, and he signals their southernness by their language. Huygens was based in Holland, but his family came from the south. His play Trijntje Cornelis is set in Antwerp in the Brabant area, and the characters are marked by their Brabantic language. All three plays are set in socio-economically modest circles, very different from the upper and upper-middle ranks to which the authors and the audience belonged. De Vooys (1970: 103) argues that neither Hooft nor Bredero considered local vernaculars unworthy of being used in artistic works. It is significant, however, that they only used markedly local forms in farces, not in more serious plays nor in lyrical poetry. It is also significant that these local forms are easily detectable, as it implies the relative neutrality of the other linguistic forms. There clearly was an awareness of local and supralocal forms, and local forms were considered more appropriate for farces set in a socially lower environment. There is thus no need to doubt the regional and social linguistic hierarchies implied.

\subsubsection{Developing neutrality through erasure}

After the Twe-spraack (1584) and its second edition (1614; Dibbets 1985: 4), the first fully-fledged grammars of Dutch are van Heule (1625) and van Heule (1633). References to the wider continental West Germanic context become scarce from the seventeenth century onwards (see Section 6.4.5). Attention is paid to forms that are considered to be typical of particular regions within the present-day Dutch language area. Van Heule often discusses variants from different regions (van der Wal \& van Bree 2008: 210-216), praising, for example, Brabantic for its diminutive formation and Frisian for specific phonological characteristics (1633: 161-162). At the same time, he aims to describe, and prescribe, a common language, a variety that can be used throughout the language area and that is superior to other varieties, founded on the literary language of the best poets (Dibbets 2003c). Here, van Heule aligns himself with the well-known pan-European debates on good and bad language that surfaced from the Early Modern period onwards (cf. e.g. Ayres-Bennett \& Seijido 2013). A similar line of reasoning can be found in Leupenius's 1653 grammar Aanmerkingen op de Neederduitsche taale ('Remarks on the Dutch language'). He also favours usage as a guide for a grammatical description, which he elaborates as follows: 
De gewoonte sall ons de wett stellen; niet een opgenomene gewoonte van desen of geenen in het bysonder, niet van eene Stad, of Landschapp, daar ieder iet besonders heeft, dat groote verscheidentheid veroorsaakt: maar die door den gemeenen drukk en dagelykschen ommegang opgenoomen en gebillykt is.

(Leupenius 1653: $\mathrm{A} 2^{\mathrm{v}}-\mathrm{A} 3^{\mathrm{r}}$ )

Custom will be our law; not an acquired custom of this or that particular person, not of a specific city or region, where each has something special, which causes great diversity; but the custom that is used and approved of by common print and in daily contact.

Van Heule (1625: 116) had also claimed that there was a common language in writing as opposed to regional diversity in speech. Leupenius extends the argument to the spoken language. Disregarding the reliability of such claims about the presumed uniformity of these varieties, it should be noted that Leupenius aims to codify a common variety that is idiolectally and regionally unmarked, i.e. he aims at a neutral variety. This common variety is added to the existing repertoire of individual, urban and rural forms. He also incorporates a hierarchy in his view of sociolinguistic space, not explicitly, but it is of course implied by the fact that this specific variety is worth the effort of a grammatical description.

The neutrality argued for by Leupenius feeds on the supralocalisation of specific variants. Forms that are found in print books and that are subsequently spread over the language area are preferred, whereas localisable forms are rejected. By this time, neutrality does not consist of a combination of forms from various regions, but is rather the result of variant reduction, with the selection of a form being boosted by it being used in a wider region. In other words, neutrality as patchwork gives way to neutrality through erasure. It was in this period that the official Bible translation, ordered by the States General, came out (1637). For almost twenty years, translators and proofreaders originating from almost all regions in the Low Countries worked on the translation (van der Sijs 2004: 133-143). The end result was a Dutch text that lacked easily recognisable regional forms, which were carefully avoided by the team of translators and proofreaders (van der Sijs 2004: 141). Here, too, neutrality through erasure replaced the sixteenth-century practice of neutrality as patchwork.

At the end of the seventeenth century and in the early eighteenth century, two metalinguistic texts were published in which reference was made to the ancient Greek situation of several dialects and one koine, as de Heuiter (1581) had done (Section 6.4.1). Whereas de Heuiter had claimed that his spelling system was the result of patchwork, the texts from around 1700, while acknowledging the existence of many regional varieties, give preference to one of these varieties, which is elevated to the level of commonality through a hierarchising discursive move that Joseph (1987: 2) aptly called synecdochic. Winschooten (1683) argues that various 
dialecti can be distinguished in Dutch, as in Greek. This should not be done at the most local level, however, as this would lead to as many dialecti as there are "peoples, districts, even cities" (1683: 74; my translation). Instead, Winschooten distinguishes four regional writing traditions: the southern (including Flemish), western (including Hollandic), eastern (including Gueldrish) and northern (including Frisian) traditions. In addition, there is the algemeene spelling 'common spelling'. In practice, Winschooten appears to equate the Hollandic dialectus with the common language (Vosters \& Rutten 2013: 6-7).

Similarly, Verwer $\left(1707:{ }^{\star} 3^{\mathrm{r}}\right)$ argues for a lingua communis, a common language that exists in addition to the various dialects. Interestingly, Verwer takes great pains to distinguish between the common language and the dialectus poëtica 'literary dialect' $\left(1707:{ }^{\star} 3^{r}\right)$, which seems to be at odds with the good usage tradition referred to above. He argues that the common language can be found in the 1637 Bible translation and in certain Middle Dutch sources, not in contemporary literary sources (van de Bilt 2009: 58-59, 63 and see below, Section 6.4.4). He also states that the common language is essentially Holland based (Verwer 1707: 5). Moreover, Verwer explicitly says that he focuses on the written language, not on the spoken language, where variation is widespread, in particular in pronunciation (Verwer $1707:{ }^{*} 3^{\mathrm{v}}$ ). As before, there is no need to doubt the high place occupied by the lingua communis in the hierarchy of varieties, and Verwer even argues that eventually, the common language could be described and explained in a Dutch-language grammar of Dutch, so that the illiterate $\left(1707:{ }^{*} 6^{v}\right)$ can benefit from it. First, the erudite need to decide on the grammatical description of the common language. As yet, the lingua communis is the supralocally applicable Holland-based variety of written Dutch that is added to the sociolinguistic repertoire (Daan 1989: 180). ${ }^{3}$

From the late sixteenth to the early eighteenth century, a general awareness of the variety of spoken and written Dutch of the time can be discerned. It is also clear that in the fullest awareness of the actual variety of Dutches, commentators tried to fix only one of these varieties, mostly a written variety based on writing practices prevailing in the larger Holland area. Often, this one variety is also hierarchically conceptualised as the best variety. Throughout the period, it is argued that the Dutch language is in need of polishing, a preoccupation that was intensified at the beginning of the eighteenth century.

3. Note that around the middle of the eighteenth century, the Greek scholar Tiberius Hemsterhuis claimed there was a supralocal form of spoken Dutch, different from regional varieties and used in particular among the higher social ranks (Hemsterhuis 2017: 103-105). 


\subsubsection{Polishing the mother tongue}

A main argument put forward by writers of grammars and orthographies to justify their normalising work on Dutch concerns the state of the language. Its state would not conform to its high place in the hierarchy of languages and it therefore needs to be polished, i.e. normalised and regularised. The call for polishing thus depends on discourses of hierarchisation, especially on the external hierarchy according to which Germanic languages are 'better' than Romance languages (Section 6.4.2). To argue for polishing, cultivation, perfection and the like is to argue for action, and often follows from complaints about the bad state of the language. The Milrovian complaint tradition (Milroy \& Milroy 2012) is the other side of what we could call the grammatical action tradition (Hundt 2000; Rutten 2006). It is easy to find parallels in neighbouring language areas, where grammarians and language commentators equally justify their activities with reference to a complaint, from Pudor's $\left(1672: x 2^{r}\right)$ grievance about "ein grosser Mangel" in contemporary German to Swift's well-known Proposal for correcting, improving and ascertaining the English tongue (1712).

A plea for linguistic polish is very much part of Dutch eighteenth-century metalinguistic discourse, which brings to mind the rise of politeness as a tool for social distinction in contemporary England and the concomitant socially stratified myth of polite language (Fitzmaurice 2010; Watts 2011: 183-208). Nevalainen (2014: 106), discussing the interplay of language norms and use in seventeenth-century English, reminds us that we need to take into account the target audience that language commentators and prescriptivists had in mind. This is also clear for the Dutch seventeenth century, where an important grammarian such as van Heule (Section 6.4.3) notes that his use of the Latin descriptive system makes it easier for those familiar with Latin to learn Dutch. But this also means that those unfamiliar with Latin concepts and terminology will have a hard time learning Dutch from his grammar book. The question of target audiences becomes more pressing in the course of the eighteenth century.

The elitist and mainly Vondelianist normative tradition of the early eighteenth century (cf. Chapter 4) almost appears to constitute a coordinated programme with its focus on various aspects of the language, and its authors who engage in similar social and professional networks (Dibbets 1992; Rutten 2006). Francius (1699) is targeted towards ministers and primarily focused on orthography, van Hoogstraten (1700) on gender, Nylöe (1703) is characterised by a great interest in style, and Moonen (1706) is the first full grammar in decades. The target audience of these Vondelianist publications mainly consists of an elite group of educated men, mostly ministers and poets. The authors aim at the normalisation of specific registers such as poetry, literary prose and sermons. They take examples from literary sources 
from the past, and present these as perfect exempla of what normalised written Dutch should be like. With their elitist orientation, they fit well into the tradition of sixteenth- and seventeenth-century grammar writing, which was generally targeted towards the learned (van der Wal 1990). Until the middle of the eighteenth century, polishing the mother tongue was primarily an elitist leisure activity (Rutten 2009).

With their restricted focus on specific registers and specific audiences, the authors of the early eighteenth century demonstrate that the variety they are describing is but one variety. While we do not need to doubt that many of these linguistic commentators also consider this variety the best variety - if only because they talk about polishing, cultivation, perfection and so on - it is also clear that they consider this one variety 'perfect' in specific situations and/or text types. It is the variety of Dutch that should be used in poetry, literary prose and sermons. Nothing is said about other registers or about the spoken language. When the spoken language does enter the arena, the debate is about the usefulness of the spoken language as a source for the activity of grammar writing. In a discussion between two language experts, viz. van Hoogstraten and Séwel, author of a Dutch grammar (1708), van Hoogstraten along with his friend Verwer (e.g. 1707) accused Séwel of modelling his grammar too strongly after the spoken language. Early eighteenth-century normative grammar is based on the written language and targeted towards the written language - it is first and foremost a textual discipline, in which references to the spoken language hardly occur (Rutten 2006: 373-378).

\subsubsection{Reconceptualising the mother tongue}

The eighteenth-century authors referred to in 6.4.4 discuss their target variety using terms such as mother tongue. While they acknowledge that they are only interested in certain written manifestations of the mother tongue, it is important to ask what they mean by the mother tongue, especially against the background of its earlier very broad West Germanic conception (Section 6.4.2). In the course of the seventeenth century and in the early eighteenth century, the concept of the language area dramatically changes when compared to the earlier periods. As argued by Vosters \& Rutten (2013), there are significant changes in the linguistic identities of language commentators from the sixteenth to the eighteenth century, signaling the changing conceptualisations of the Dutch language area and the mother tongue. In the sixteenth and seventeenth centuries, metalinguistic discourse often feeds on a double linguistic identity. On the one hand, the language area is conceptualised as spanning a large territory, to which even Tallinn can belong, and the authors consider themselves part of this large area. On the other hand, they also identify strongly with a local or regional variety to the extent that many prescriptions, especially in 
the sixteenth century, are based on local or regional varieties. Both the local and the broad West Germanic perspective almost disappear in the later seventeenth and particularly in the eighteenth century, giving way to a single linguistic identity that can perhaps best be summarised as national.

This also means that the political split of the Low Countries into a northern and a southern part becomes reflected in metalinguistic discourse in the sense that references to the other part gradually disappear. Northern metalinguistic discourse of the eighteenth century, in particular, is distinctively Dutch in the modern sense. There is a general lack of awareness of both local/regional varieties as well as the Dutch varieties used in the southern Low Countries, i.e. present-day Belgium. This nationalisation of the discourse is arguably the most important development in eighteenth-century metalinguistic discourse and it signals the transition from neutrality as a shared space to neutrality as unmarkedness.

\subsection{Neutrality as unmarkedness}

Throughout the sixteenth, seventeenth and eighteenth centuries, metalinguistic discourse was engaged in the construction of a neutral variety suitable for supralocal communication. This neutral variety was often considered to be not just common ground for people from different areas, but also a superior variety more appropriate for written communication, i.e. a verticalised shared space. The major change in the history of standardisation, however, occurs in the eighteenth century, when important concepts such as the mother tongue, hierarchisation and polishing are radicalised and brought together into one coherent language ideology, viz. SLI, and combined with social and political ideas about the nation and about social action and emancipation. Watts (2011:211), analysing the English situation in the eighteenth century, talks about the myth of polite language changing into the myth of the legitimate language, a transformation that parallels the change from the polished variety discussed in Section 6.4.4 to the single, neutral and unmarked form of language that will be discussed in the present section.

One of the central tenets of SLI is the belief in the existence of neutrality as unmarkedness. In this section, I single out some crucial discursive steps taken in the eighteenth century that led up to SLI. First, I discuss the nationalisation of language and grammar as undertaken in educational discourse and in policy measures (6.5.1). Section 6.5.2 focuses on the new, radicalised version of neutrality, i.e. neutrality as unmarkedness. 


\subsubsection{Educational discourse and policy}

In Chapter 4, I argued that fundamental changes took place in eighteenth-century metalinguistic discourse, with the initial elitist approach gradually giving way to a more inclusive perspective. This socially broader focus was radicalised towards the end of the century, when grammar books were often addressed to the whole population, and meant for use in schools. These changes in metalinguistic discourse are paralleled by similar developments in educational discourse (see also Section 2.4). In the second half of the eighteenth century, the Netherlands were characterised by a high degree of sociability, with private and semi-public societies constituting the main infrastructure of social and cultural life. Within these societies, numerous debates and essay competitions were organised, and they often also published essay volumes, periodicals and/or yearbooks. One of the topics that were heavily discussed was education.

Important essay competitions were held in the 1760s and the 1780s. In 1761 and 1763, the Hollandsche Maatschappij der Wetenschappen ('Holland Society for the Sciences'), based in the city of Haarlem, held two essay competiions, the first on the physical education of children, the second on their emotional and intellectual education (Los 2005: 183-184). The question to be addressed by the authors was Hoe moet men het verstand en het hart van een kind bestieren, om het te eeniger tyd een nuttig en gelukkig mensch te doen worden? 'How should one govern the mind and the heart of a child in order to make it a valuable and happy human being some time in the future?' Five out of 43 submissions were granted the honour of being published in the society's Verhandelingen ('Treatises'), volume IX (1766; cf. Los 2005: 195-207). The authors of these five essays were Johann Formey, Allard Hulshoff, Henri Châtelain, Kornelis van der Palm and an anonymous fifth author. They discussed topics such as the general principles of the intellectual and psychological development of children, religious and moral education, and private and public education (Los 2005: 254).

The winner of the gold medal, Formey, and Hulshoff did not discuss language, the others did, though not at great length. Châtelain (1766: 76-77) merely noted that the first thing any child should learn is de taal 'the language', viz. hunne Moedertaal 'their mother tongue', without however explaining what the language or the mother tongue entailed. On the same page (p. 77), he stated that children should be taught two or three languages at the same time, for example Dutch and French. The anonymous author (1766: 19-22) mainly argued how reading could be taught in a playful way. Van der Palm, finally, explicitly argued for reading and writing instructions at the earliest stage of the child's educational career: Het eerste 't welk een Kindt, in wat staet het ook geboren is, moet leeren, is het lezen en schryven zyner Moedertael', en hier van mag men niet afscheiden, ten zy het eene goede vordering 
in dezelve gemaekt hebbe "The first thing that a child, in whatever state it is born, has to learn, is to read and write its mother tongue, and this should not be ended, unless it has proceeded significantly' (1766: 72). Van der Palm also does not specify his concept of the mother tongue.

Language became a more important topic in another essay competition, held by the Zeeuws Genootschap der Wetenschappen ('Zeeland Society for the Sciences') in 1780. This time the question was Welke verbeteringe hebben de gemeene of openbaare, vooral de Nederduitsche Schoolen, ter meerdere beschavinge onzer Natie, nog wel nodig? Hoe zou die op de voordeeligste wyze kunnen ingevoerd, en, op een bestendigen voet, onderhouden worden? 'Which improvements do the general or public schools, particularly the Dutch schools need for the greater cultivation of our nation? How could this be implemented in the most advantageous way, and be maintained in a stable manner?' The winning essays were published in 1782 in volume 8 of the Verhandelingen ('Treatises') of the Zeeland society. The authors were H. J. Krom, Kornelis van der Palm again, and D. C. Van Voorst. The society also published a collection of extracts from the other submissions. The authors discussed many different aspects of the school system, such as the quality of the schoolmasters, the exams, the inspection, the curriculum, the material conditions, et cetera. They also discussed language. Krom, in his essay, stressed the importance of orthography as a school subject, adding

waar in de Meesters over het algemeen wel wat beter behoorden ervaren te zyn; en waartoe een korte, doch goede en duidelyke Nederduitsche Grammatica of Letterkunst, door publicq gezag, overal in Neêrlands Schoolen ingevoerd, niet ondienstig zyn zou.

(Krom 1782: 85)

in which the schoolmasters in general should be somewhat better trained; and for the purpose of which a short, but good and clear Dutch grammar, implemented by public authority in Dutch schools everywhere, would not be unhelpful.

In a lengthy footnote to this passage, Krom (1782: 85-90) acknowledged the arbitrariness of many language norms and stressed the importance of uniform language norms as such, repeating an earlier claim that this would greatly contribute to the advancement of Dutch schools:

't zou dan, myns oordeels, aanmerkelyk diepen tot verbeteringe en beschaavinge van de Schoolen, zoo wel, als om eens eindelyk onze moedertaal in zulke en andere byzonderheden op eenen vasten voet te brengen, wanneer een Nederduitsche Grammatica, door drie of vier kundige Mannen opgesteld, en door publicq gezag bekragtigd, in alle Schoolen van Nederland wierd ingevoerd. 't Is mij om het even hoe men omtrent de verschillende spelwyze van sommige woorden bepaaling maakt, als het maar bepaald is, hoe men schryven moet.

(Krom 1782: 88; emphasis in the original) 
It would then, in my opinion, significantly increase the improvement and cultivation of the schools, as well as finally regularise our mother tongue in such and other details, if a Dutch grammar, written by three or four skillful men and ratified by public authority, were implemented in all the schools of the Netherlands. I don't care what decisions are made concerning the spelling of certain words, as long as it is decided how one should write.

In the same vein, and after having argued extensively that "knowledge of our mother tongue" is one of the most important requirements of schoolteachers, van der Palm in his essay explained that de ligtste Spraekkunst 'the easiest grammar' is needed to teach children the language. Not without commercial interest, he continued that he could recommend "the one by $\mathrm{K}$. van der Palm, which is the easiest I know of, and primarily drawn up for the young” (1782: 293).

The third prize essay and the collection of quotations from the other submissions do not address the language issue in as much detail as Krom and van der Palm did. They do, however, give insight into the correcting and normalising practices of schoolteachers. Van Voorst (1782: 369) explained that a good way of teaching the language is by reading out loud a certain text, which the children then have to write down met hunne eigene spelling 'in their own spelling'. Afterwards, the schoolteacher will discuss all the mistakes they have made. Considering the fact that the essay competition was held by a Zeeland-based society, it seems significant that van Voorst singled out one of the most prominent features of the spoken language of the province of Zeeland, and of the south-west of the Dutch language are generally, viz. $h$-dropping. The same topic appears in the collected quotes from other essays, where an anonymous author addressed the variable use of $h$ in initial position, i.e. $h$-dropping as well as $h$-prothesis in words with an initial vowel: ${ }^{4}$

Het wel spellen legt den eersten en besten grond van wel te leezen, en goed te schryven, en mangelt het hier aan, alle hoop tot eene verdere beschaafde vordering zal in rook verdwynen. Niet zelden volgt men in deezen de gewoonte der Stad of van 't Dorp, daar zich de Schoolen bevinden. By veelen heerscht eene onaangenaame gewoonte; men laat, by voorbeeld, spellen: Aap, Aal, Handen, Hoofd, Haazen, Harten, Haalen, Hout, Hoop, Ezel, Een, El, Ey, en men laat toe dat zy uitspreeken, Haap, Haal, Anden, Oofd, Aazen, Arten, Aalen, Out, Oop, Hezel, Heen, $\mathrm{Hel}, \mathrm{Hey}$, en honderd diergelyke meer. Dit dient vooral verbeterd.

(Verzameling 1782: 414)

4. See Rutten \& van der Wal (2011) for an analysis of $h$ in actual language use in private letters from Zeeland dating back to the seventeenth and eighteenth centuries. 
Spelling well lays the first and best foundation of reading well, and writing well, and if this is lacking, all hope of a further cultivated advancement will vanish into thin air. Often, the common usage of the town or village where the schools are located is followed in such matters. Among many, an unpleasant custom dominates; for example, one has them spell Aap 'monkey', Aal 'eel', Handen 'hands', Hoofd 'head', Haazen 'hares', Harten 'hearts', Haalen 'get', Hout 'wood', Hoop 'hope', Ezel 'ax', Een 'one', $E l$ 'yard', Ey 'egg', and one permits that they pronounce, Haap, Haal, Anden, Oofd, Aazen, Arten, Aalen, Out, Oop, Hezel, Heen, Hel, Hey, and one hundred similar examples in addition. This needs to be improved in particular.

The reification of language as carried out in grammatical practice is a well-known topic in standardisation studies (cf. Le Page \& Tabouret-Keller 1985: 236). In eighteenth-century metalinguistic discourse, there is a general tendency to promote this reified version of highly variable linguistic practices among ever larger parts of the population. Language became ever more important in educational discourse, and reference was made to the importance of mother tongue education. It seems unlikely that the notion of the mother tongue here referred to the variety children learnt from their mothers.

As argued in Section 2.3, the national language policy was embedded in a broader sociopolitical discourse of language and nation, in which homogeneity was a crucial concept. The educational discourse outlined above was characterised by an ideal of inclusiveness: the interest in the education of the people principally concerns all members of the nation (Los 2005). Key issues in discussions about education, which were mostly held by upper- and upper-middle class men, were volk 'people' and vaderland 'fatherland', and an ideal of inclusive citizenship (Lenders 1988; Los 2005: 314-315). The ultimate goal of these discussions is the spread of Enlightenment through the population as a whole.

From 1801 onward, a series of educational laws were passed, the end goals of which were to advance the intellectual faculties of Dutch children and to teach them social and Christian virtues (Boekholt \& de Booy 1987: 99). The original impetus to the educational reforms came from the desire to offer the whole population the same educational opportunities. In the same spirit, the minister of national education J. H. van der Palm issued the language regulations that led to the publication of the official spelling and grammar (Siegenbeek 1804a, Weiland 1805a). As discussed in Section 2.5, the inspiration for the educational laws was largely taken from a document produced by one of the most influential societies of the period, founded in 1784, viz. the Maatschappij tot Nut van 't Algemeen 'Society for Public Advancement'), usually shortened to 't Nut. When the democratic government of the Batavian Republic called for a national educational policy (Boekholt \& De Booy 1987: 95-96), it turned to 't Nut, which published its report Algemeene Denkbeelden over het Nationaal Onderwijs ('General Ideas on National Education') 
in 1798 (Dodde 1971). In this report, 't Nut discussed a wide variety of topics and policy measures that were considered necessary for the design of a whole new system of schools, school inspection, teacher training and curricula. It also argued that mother-tongue education was necessary, and that grammar should be taught in schools (Lenders 1988).

\subsubsection{Enlightenment, emancipation, anonymity - and authenticity}

The discursive changes in metalinguistic and educational discourse led to new policies in the first decade of the nineteenth century, ideologically underpinned by sociopolitical ideas about a homogeneous nation and an inclusive concept of citizenship. In its most basic form, the linguistic implication of these new ideas and policies is that every member of the nation should use the language of the nation, or from an educational perspective, that every member of the nation should be taught the language of the nation. It is from emancipatory discourse, in particular, that it becomes clear what this means sociolinguistically, viz. a new form of neutrality characterised by unmarkedness - which constitutes the historical manifestation of a discourse of anonymity.

Among the main themes of Dutch Enlightenment discourse are emancipation and social action. Traditionally, the Dutch Enlightenment is considered moderate, Christian and bourgeois (Sturkenboom 1998: 37), even though 'radical' developments have attracted most attention in recent years (e.g. Israel 2001). In this context, the term bourgeois refers to the fact that not just upper class but also (upper) middle class citizens were engaged in Enlightenment discourse as it developed in societies, newspapers and periodicals. The Dutch eighteenth century is marked by the rise of a new authority, viz. public opinion, and gave birth to what is sometimes called a national community of communication (Kloek \& Mijnhardt 2001: 61-63). The importance of sociability in the development of this national community can hardly be underestimated. In around 1800, an intricate structure of societies characterises the Netherlands, with most towns and cities holding a number of learned and cultural societies and freemasons' lodges, and with reading clubs being even present in hundreds of smaller villages (Kloek \& Mijnhardt 2001: 104). It is estimated that, at the beginning of the nineteenth century, no less than 3 to $5 \%$ of the male adult population was or had been involved in one or more societies (Kloek \& Mijnhardt 2001: 104). This may still seem fairly limited from a modern perspective, but in fact it was a radical change, taking place from around 1770, when the previous social exclusiveness, which meant that societies were only populated by members from the noble and non-noble ruling classes, gave way to societies accepting, for example, small merchants and artisans (Kloek \& Mijnhardt 2001: 116). In addition, women had access to some of these societies and were more active in intellectual 
exchanges than previously thought; nevertheless, the traditional predominance of men still held (Baar-de Weerd 2009).

The society most well known for its involvement in emancipation and social action, particularly concerning the education of the people, is the aforementioned 't Nut (Section 6.5.1, see also 2.4 and 4.4). This middle class society made up of the middle classes with its inclusive ideology of public civilisation had as its main aim social change, to be reached through the implementation of its highest ideal, viz. the dissemination of enlightened knowledge among all layers of society (Kloek \& Mijnhardt 2001: 122). Lenders (1988) offers a thorough and critical discussion of both ideological and practical aspects of this typically eighteenth-century movement for volksverlichting 'lit. folk enlightenment, enlightenment of the people'. Discussing i.a. medical and paedagogical discourses, reward-and-punishment practices and language instruction, he shows how the socially privileged bourgeoisie made efforts to educate the people, and in particular the lower ranks, in accordance with their own ideas, that is, with ideas articulated and discussed among the upper and middle ranks (e.g. Lenders 1988: 21-22).

In the same vein, metalinguistic and educational discourses generated ideas about the emancipation of the lower ranks through their envisaged appropriation of the language of the upper and middle ranks. Drawing on ideological notions of homogeneity and inclusiveness, language was discursively constructed as a symbol of the Dutch nation. To adopt Le Page \& Tabouret-Keller's (1985: 236) terminology, the reified version of Dutch found in grammars and schoolbooks underwent totemisation. Linguistically, this means that it lost its indexicality related to register, text type or situational context, acquiring a new index of neutrality as unmarkedness instead. Notwithstanding the possibly divergent patterns arising from actual language use, where it is all but certain that language users only oriented themselves to the reified version of Dutch (cf. Chapter 3), metalinguistically this variety was now considered the only real variety of Dutch.

The text in which this position is perhaps most explicitly defended is a prize essay called Het belang der waare volksverlichting ('The importance of the true education of the people', cf. Section 2.4). The anonymously published essay was written by H. W. van der Ploeg, and published in 1800 by 't Nut, which had awarded it a gold medal. Van der Ploeg describes volksverlichting as follows:

Onder eene waare volksverlichting - versta ik: "Eene, door onderwijs, en eigen oefening verkreegene, vatbaar- en vaardigheid der gezamenlijke burgers van den Staat door alle classen heen, zo wel vrouwen als mannen, waar door zij, in het algemeen, eene duidelijke, op overtuiging gegronde, kennis hebben van - en een gezond oordeel vellen - over die zaaken, welke, in het gemeene leven, eenen onmiddellijken en gewigtigen invloed hebben op hunnen natuurlijken en zedelijken welvaart, ten opzichte van hun tijdelijk en van hun toekomend bestaan".

(van der Ploeg 1800: 10-11) 
True enlightenment of the people entails: knowledge and skills, acquired through education and individual practice, among all the citizens of the state of all social ranks, both men and women, which generally enable them to have a clear and well-founded understanding of - and to pass judgment on - those matters, which, in daily life, exert an immediate and important influence on their natural and moral well-being with respect to their transitory and their future existence.

The typically Christian inspiration of Dutch Enlightenment discourse is apparent in this quotation, as is the close link between the end goal of 'a true enlightenment of the people' and the means to reach this goal, viz. education. The inclusive character of the discourse is also very clear. On the following pages, van der Ploeg does create social differences, however, arguing that knowledge of foreign languages, including dead languages is not of any use to the people, i.e. to the masses, who should focus on the moedertaal 'mother tongue' instead (van der Ploeg 1800: 12-13). Van der Ploeg then lists the various components of volksverlichting (1800: 16-17), among which are knowledge of and belief in God, knowledge of the body, the mind, and the character of man, knowledge of man's position on earth, knowledge of man's duties, and so on, and also eene regelmaatige kennis der moedertaal 'a regular [i.e. founded on rules] knowledge of the mother tongue'. The mother tongue is put forward as what binds the individual members of the population together, irrespective of their social position or gender. The implied identification of language, state and nation is striking. Societal multilingualism is ruled out, and individual multilingualism is marginalised to being a privilege of certain social groups.

Van der Ploeg's position becomes even more apparent in the section detailing why knowledge of the mother tongue is so important. Without a general and rule-based knowledge of the Moedertaal des Lands 'the mother tongue of the country' (1800: 35), true enlightenment of the people is impossible. What is more,

het [is] nodig, dat het volk, zal het verlicht kunnen heeten, of kunnen worden, in alle Departementen van den Staat, niet alleen gelijkluidend spreeke, maar ook zoodaanig, als men in de volksschriften gewoon is te schrijven en in de openlijke aanspraaken zich uit te drukken.

(van der Ploeg 1800: 35)

it is necessary that the people, if they will ever be or become enlightened, in all departments of the state, not only speak identically, but also in the way that is customary in popular publications and in public speeches.

This is a clear call for nationwide homogenisation both in the spoken and the written language. Van der Ploeg wants the spoken language to conform to the supralocal variety used in writing and in formal spoken registers. This implies that forms and/or varieties that differ markedly from the supposedly supralocal variety need to disappear: 
Er zou dus een groot stuk der verlichting gewonnen zijn, indien in een land geene, zo genoemde, Platte Taalen gevonden wierden, die zeer hinderlijk zijn in het onderwijs der jeugd, en dus ook in de algemeene verlichting, welke laatste toch alleen, bij het gros des volks, door het eerste kan verkregen worden.

(van der Ploeg: 1800: 35)

A great part of enlightenment would be gained, if no so-called vulgar languages were found in the country, these being true hindrances in the education of the young, and therefore in the general enlightenment, too, which can only be reached, for the majority of the population, through education of the youth.

Recalling similar contemporary actions for the elimination of the dialects in France (de Certeau, Julia \& Revel 1975), van der Ploeg's position implies that there is only one language variety with the right to exist. Disregarding the register-based, genrebased and situational restrictions connected to the supralocal variety in the preceding period, he singles out this one variety, calls it the mother tongue of the nation, and devaluates all other forms and varieties as vulgar, that is, as marked deviations from the language as such. The advocated act of homogenisation entails a shift from neutrality as a shared space to neutrality as unmarkedness. Van der Ploeg emphatically embraces the idea of language as a neutral tool in the emancipation of the people, specifically, of less-privileged sections of the nation. Behind this position lies a concept of the one Dutch language as an anonymous entity.

The unmarkedness implied by the fact that there is only one variety with the right to exist is elaborated upon in another part of the essay, where van der Ploeg returns to the theme of language. He does not limit himself to deploring the existence of platte taalen 'vulgar languages', i.e. regional dialects, but explicitly states that their verbanning 'expulsion, elimination' is an important means to reach the enlightenment of the people (1800: 129). He continues:

Maar op welk een wijze zou dit geschieden? dit is de groote vraag. - Ik weet geen andere, dan dat de schoolmeesters [...] 'er voor zorgen, dat onder hun toezicht, alleen - de zuivere Moedertaal gesproken wordt, dat zij daarin opzettelijk onderricht geeven - het zij, door gesprekken, het zij door schrijven; dat zij de kinders aanhouden $[\ldots]$ om onder elkander en bij hunne ouders steeds nederduitsch te spreeken. Indien dit alles met ijver en oordeel geschiede, zo zoude welhaast het platte vanzelf wegvallen.

(van der Ploeg 1800: 129-130)

But in what way should this happen? This is the big question. I know no other way than that schoolteachers take care that only the pure mother tongue is spoken under their supervision, that they teach it expressly, either in conversation or in writing; that they force the children to speak Dutch amongst each other and with their parents. If all this were to happen diligently and competently, the vulgar would disappear almost automatically. 
Here, the domain of the national language is extended to include even private conversations within the family.

The shift towards a conceptualisation of the supralocal variety as the only and therefore unmarked form of language within the language area and the nation is furthermore signaled by the labels van der Ploeg uses to refer to it. The supralocal written form of Dutch had been referred to previously as the mother tongue (Section 6.4). Calling it de zuivere Moedertaal 'the pure mother tongue', van der Ploeg invokes the traditional importance of purification, of cultivation and polish (Section 6.4.4). However, set against the background of inclusive ideas about citizenship, about the enlightenment discourse on the top-down education of the people, and about the elimination of dialects, the notion of purity now also indexes uniqueness: the pure mother tongue is the only true mother tongue, that is, a language that is unmarked and neutral, since it is the only true language that exists within the nation. All other varieties are marked aberrations. This change in the discursive construction of the mother tongue is stressed by the second part of the sentence, where van der Ploeg simply refers to his preferred variety as nederduitsch 'Dutch', which is then contrasted with het platte 'the vulgar, the dialectal'.

This final discursive move is crucial in the process of totemisation or nationalisation (Burke 2004: 166). The implication is that what people speak with their family and friends, that is, the language they initially learn from their parents, is not actually their mother tongue, but a marked deviation of it at best. That is, what they learn from their mothers is not their mother tongue. This seemingly absurd consequence makes perfect sense, however, given the dominant ideology of homogeneity, which is politically translated in terms of inclusiveness. Members of the nation who do not use the neutral variety, and who have a regional dialect as their mother tongue, nevertheless have the supralocal variety as their mother tongue, precisely by virtue of their membership of the one homogeneous Dutch nation. Their true mother tongue simply needs to be brought to light through education.

This final discursive move, which robs speakers of their mother tongue and imposes upon them another mother tongue, feeds on a similar idea of authenticity as discussed in Section 5.3. The Golden Age Myth was built on authenticity as a distinct characteristic of the language of the Golden Age. Here, it turns out that the anonymous and neutral variety of Dutch needed for emancipation and Enlightenment purposes equally depends on authenticity. The nation can have only one language, which is necessarily the true language and mother tongue of any of its members. 


\subsection{Final remarks}

Neutrality is a particularly important concept in Dutch metalanguage from the sixteenth to the nineteenth century. The sixteenth century is mainly characterised by a striking awareness of regionality as well as by the effort to attain neutrality through patchwork. In the course of the sixteenth and seventeenth centuries, hierarchisation becomes more prominent. Varieties and variants are brought into a hierarchy and selection gains in importance. As a consequence, a shift toward neutrality through erasure can be witnessed. This is then followed by the typically early eighteenth-century preoccupation with polish, but still the polishing of a specific and shared variety for special purposes such as poetry or sermons. The combination of linguistic action in the interest of a refined variety with sociopolitical ideas about homogeneity and inclusiveness, and the ideal of one language-one nation subsequently led to the nationalisation of the language in the decades around 1800 . A new kind of linguistic neutrality is discursively constructed, its distinguishing characteristic being unmarkedness. It feeds on extralinguistic ideas about the people as a homogeneous unity, emancipation and nation-building. The emancipatory inspiration of many Enlightenment writings immediately implies the application of this unmarkedness within the context of the education of the people. This requires an intriguing discursive move by which the people are stripped of their mother tongue and supplied with the new and unmarked mother tongue instead.

The broad historical development outlined here entails a conceptual shift from neutrality as a shared space to neutrality as unmarkedness. The decades around 1800 constitute the decisive period in this shift. Obviously, it cannot be excluded that there were people in the sixteenth or seventeenth century who radicalised the hierarchy of varieties to the extent that they considered the so-called neutral variety the only variety with the right to exist. At the same time, metalinguistic comments signalling neutrality as a shared space can be found after 1800 and up to the present day. I merely argue that neutrality as unmarkedness was rare before the second half of the eighteenth century, when it was politicised and became imbued with notions about nationality, inclusiveness and emancipation, and when it largely superseded the previous concept of neutrality as a shared space. In addition, many of the important and related ideas, e.g. about the mother tongue, hierarchisation and linguistic polish, already existed before the second half of the eighteenth century. Crucially, however, these ideas were brought together in the coherent framework of linguistic nationalism in the period around 1800 . 
PART III

Discipline formation 



\section{CHAPTER 7}

\section{Nationalising the lexicon}

\subsection{Introduction}

The great 'national' dictionaries of western European languages such as Dutch, English and German date back to the nineteenth century and have eminent predecessors in the eighteenth century. The first plans for a New English Dictionary were made in 1857, and the first part of what would become the Oxford English Dictionary was only published between 1884 and 1933 (Beal 2004: 57-58). As early as the mid-eighteenth century, Dr Johnson had published his famous Dictionary of the English Language (1755), a couple of years after his Plan of a Dictionary (1747). Jacob and Wilhelm Grimm's Deutsches Wörterbuch came out between 1854 and 1961. They had begun work in 1838 (Kirkness 1980: 82). They had a well-known predecessor in Adelung's Grammatisch-kritisches Wörterbuch der hochdeutschen Mundart, first published between 1774 and 1786.

The Dutch equivalent of these dictionaries is the Woordenboek der Nederlandsche Taal or WNT ('Dictionary of the Dutch Language'). Work on the WNT began in 1850-1851, the first installment was published in 1864, and the first volume came out in 1882. The WNT was completed in 1998. In the northern Low Countries, too, plans for a new dictionary dated back to the mid-eighteenth century, more specifically to 1762 , when Josua van Iperen published two essays on the topic. However, these plans would remain mere plans for a long time.

In this chapter, I discuss the dictionary projects launched between 1762 and 1852 , which is when Matthias de Vries published the final proposal for a new dictionary of Dutch, resulting in the WNT. Throughout this period, language observers agreed that a new Dutch dictionary was needed. But what is Dutch in this context? What does it refer to? Which words are part of the Dutch vocabulary and should be included in a Dutch dictionary, and which should be excluded? I will investigate this by scrutinising the various proposals and plans for a new dictionary. In other words, the main focus will be on how a specific selection of Dutch words was discursively constructed as the Dutch lexicon.

Five variational dimensions played a crucial role in contemporary discussions: region, time, domain, mode and origin (cf. Moerdijk 1994). The discourse thus mainly revolved around the following questions: what to do with regional words, with old words, with technical or specialised vocabulary, with the spoken language, 


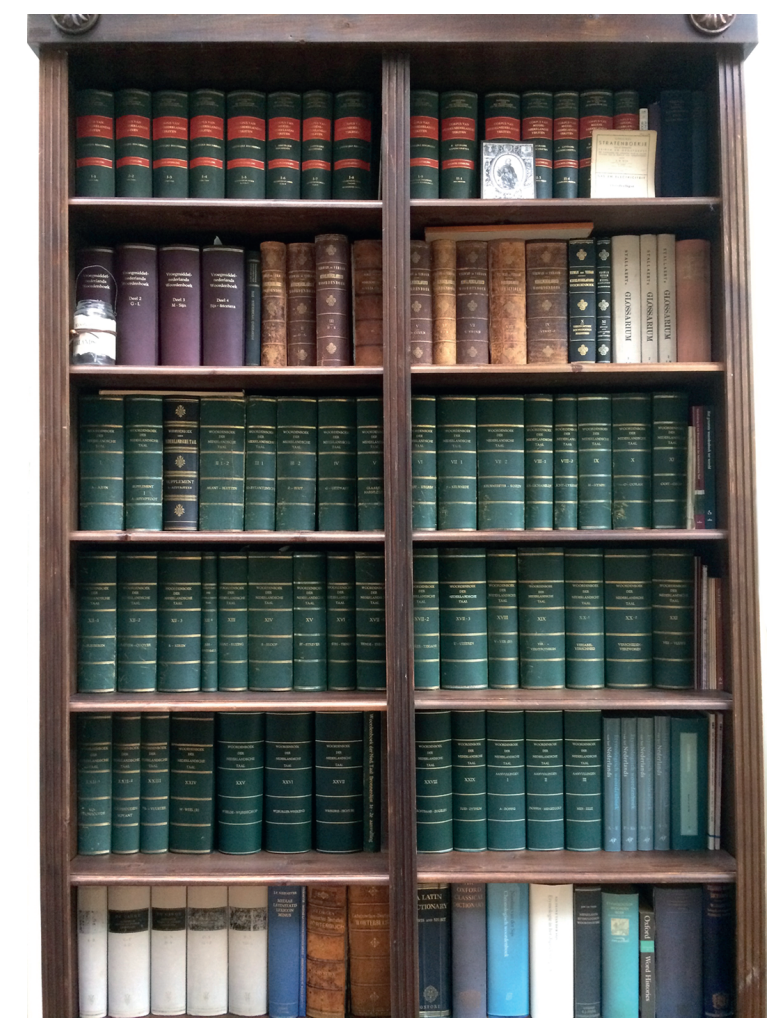

Figure 1. The Woordenboek der Nederlandsche Taal (WNT) at the Instituut voor de Nederlandse Taal (Institute for the Dutch Language)

and with loans? The main claim will be that the gradual changes in the dictionary plans reveal a process of nationalisation, according to which the initial plans with their remarkably universalist outlook became increasingly restricted. A consequence, for example, is that regionality developed into a relevant category that could be used as a yardstick to decide upon inclusion, and more often upon exclusion.

The central concepts of inclusion and exclusion have lexicological and social relevance. Lexicologically, they refer to the policy developed to decide which words will be treated in the dictionary. There is a social parallel in the inherent tension between the universalist ambition of much Enlightenment discourse, which however often developed in a national context (Porter \& Teich 1981), with prime relevance for national communication communities (Kloek \& Mijnhardt 2001). The supposed universalism of the Enlightenment has been criticised from many perspectives (cf. e.g. Schott 1997; Wokler 1997; Carey \& Festa 2013). In the case of language, too, the national interferes with the universal. Boundaries are created that limit the universal. In the first plans for a new dictionary, a 'universal', highly inclusive approach 
is advocated, aiming at the inclusion of all Dutch words found anywhere at any time. In the course of time, a much more strongly exclusive approach emerges, both lexicologically and socially, however without the discourse changing. In other words, whereas the discourse remains inclusive, certain words and language users are explicitly excluded from the national dictionary, for example words constructed as regional and dialect speakers.

In 7.2, I discuss the inclusive plans for a new Dutch dictionary developed in the 1760 s and 1770s. From the 1770s onward, commentators questioned this inclusiveness and advocated a more restricted approach (7.3). After a brief discussion of the first dictionary that was published (7.4), I turn to the new plans developed in the first decades of the nineteenth century (7.5), again characterised by an inclusive approach. Section 7.6 focuses on the discussions that took place around 1850 from which the final plan for the highly exclusive WNT arose.

\subsection{The first plans (1760s-1770s)}

\subsubsection{Van Iperen's proposal}

The first plans for a new Dutch dictionary date back to 1762, when Josua van Iperen, a minister in the province of Zeeland, published two short essays (Bergman 1851-1852; Kossmann 1966; van de Bilt 2009). The first comprised a proposal for a Nederduitsch omschryvend woordenboek ('Dutch descriptive dictionary', 1762a: 511). The second mainly contained a few examples of entries (1762b). The two essays were published in the Maendelijksche by-dragen ten opbouw van Neerland's tael-en dichtkunde ('Monthly contributions to the advancement of Dutch language and literature'). The journal editors explained that the second essay was requested by readers of the first, who were intrigued by the proposal, but who wanted to have a concrete example of the proposed dictionary (van Iperen 1762b: 551). Van Iperen's seminal first essay laid the foundation for all lexicological and lexicographical discussions in the following decades.

Van Iperen (1762a: 510) stated that existing dictionaries were either outdated or flawed. He criticised the Hollandocentric perspective in metalinguistic discourse, which regarded the language spoken outside Holland as superfluous. Apart from the regional dimension, van Iperen (1762a: 511) also reflected on domain, arguing that all crafts, professions and sciences had their specialised vocabulary, offering duizenden goede Nederduitsche Woorden 'thousands of good Dutch words'.

Nevertheless, there were limits to this remarkably inclusive approach to the Dutch lexicon. Van Iperen (1762a: 511) condemned de Straat-Stadhuis- en Hoftale 'street language, city hall language, and court language'. Street language was a 
common term to refer to the most informal spoken language (van der Wal 1994). There is also a long tradition of criticising legal, administrative and diplomatic discourse for being imbued with loans and loan translations from the Romance languages, particularly from French and Latin (de Vooys 1970: 110-112, 137-138; van den Toorn et al. 1997: 356-357). From a sociolinguistic perspective, it is interesting that informal language and loans are problematised here. Both have a distinctly social relevance and will become even more important in subsequent proposals. The supposed speakers of street language are the lower orders, the mob, and these are denied admittance to the nation later on (Section 7.6). Language contact phenomena such as loans remain problematic throughout the period, and anti-French sentiments in particular prevail.

When van Iperen (1762a: 512) explained his method for compiling the new Dutch dictionary, he referred to both spoken and written varieties. Concerning written Dutch, one of his suggestions was to excerpt Middle Dutch sources. Van Iperen (1762a: 512) also called for the establishment of a society to coordinate the work on the dictionary. Focusing on the regional dimension, he proposed a method with local correspondents who would contribute to a lexicon that was compiled in one central place (van Iperen 1762a: 512). Van Iperen (1762a: 512) also argued for the systematic collection of the technical vocabulary used by craftsmen, artisans, merchants, fishermen, sailors and so on.

\subsubsection{Van den Berg's letter}

Van Iperen's plan prompted an anomymous reaction by the Leiden student Herman Tollius (1762), who appreciated the initiative but criticised the examples. In 1769, van Iperen's plan was referred to when minister Ahasverus van den Berg, based in Barneveld in Gelderland, launched a similar dictionary plan. On 30 August 1769, van den Berg wrote a letter to the Maatschappij der Nederlandsche Letterkunde ('Society of Dutch Language and Literature'). Van Iperen had argued that the compilation of a new dictionary should be coordinated by a society, and van den Berg considered the Maatschappij to be this society. Van den Berg's letter was discussed in the annual meeting of the Maatschappij in 1770 and summarised in the Handelingen ('Transactions', cf. 1770: 22-23).

Van den Berg's proposal for a volkomen omschryvend Nederduitsch Woordenboek 'complete descriptive Dutch dictionary' (Handelingen 1770: 22) was even more inclusive than van Iperen's. He wanted to take into account both the spoken and the written language, all regional varieties as well as the language of allerlei soorten van Kunstenaers en Handwerkslieden 'various sorts of artists and artisans' (Handelingen 1770: 22), and moreover, zelfs de Straettael niet uitgezonderd 'even the street language was not excluded' (Handelingen 1770: 22). No mention is made of the legal, 
administrative and diplomatic domains. Van den Berg suggested that members of the Maatschappij could be requested to collect lexical items, and when detailing his method, he mentioned literary texts, artists and artisans as well as de Tael der Landlieden, en wel [...] die der meestafgelegene Landstreken, als welke de minste gelegenheid gehad heeft om besmet te worden 'the language of countrymen, and particularly the language of those in the most remote areas, which has had the least opportunity to become contaminated' (Handelingen 1770: 23). Finally, van den Berg also suggested that members of the Maatschappij could excerpt historical legal and administrative documents, indicating that he wanted to include the diachronic dimension into the envisaged dictionary (Handelingen 1770: 23).

Van den Berg's proposal was first sent to the monthly meeting of the Maatschappij, evaluated by a small committee, and then forwarded to the annual meeting, where it was decided that first een vollediger Plan van zulkeen Woordenboek 'a more complete plan of such a dictionary' should be made, 'before asking the members for anything in this respect' (Handelingen 1770: 23; my translation). Such a new and more complete plan should provide details of what to include in the dictionary, which sources should be used, and which method should be used to gather the data. One of the committee members was the minister Pieter van den Bosch, and he was requested to draw up the new plan.

\subsubsection{The well-reasoned plan}

Now that the Maatschappij had committed itself to the dictionary project, a new phase began, still characterised by plans and committees. In 1771, van den Bosch submitted his plan to the monthly meeting of July. It was printed in 1773 with comments by other members of the Maatschappij including van den Berg, minister and historian Adriaan Kluit (van de Bilt 2009), and minister Nicolaas Hinlópen (de Bonth, Noordegraaf \& Rutten 2016). The Beredeneerd plan tot het vervaerdigen van een algemeen, omschryvend woordenboek der Nederlandsche tale ('Well-reasoned plan for making a general, descriptive dictionary of the Dutch language', 1773) comprised fourteen folios with reflections on the general goal of a dictionary, the contents, the sources that should be used, and the method of compilation.

While van Iperen had talked about a descriptive dictionary, which van den Berg had rephrased as a complete descriptive dictionary, the well-reasoned plan introduced the notion of generality. As the Beredeneerd plan continued the inclusive approach advocated by van Iperen and van den Berg, algemeen 'general' seems to be synonymous with volkomen 'complete'.

The Beredeneerd plan (1773:2) argued that a dictionary that enabled readers to understand Dutch writings did not suffice. Instead of being just a tool, the new dictionary should comprise den geheelen schat onzer Tale 'the whole treasure of our 
language' (Beredeneerd plan 1773: 2). In published books, only part of the entire Dutch vocabulary was used, and moreover, most words only with their prototypical meanings (Beredeneerd plan 1773: 2). Van den Bosch's central argument to back up his inclusive approach involves the regional dimension. Most books are published in Holland, he argued, and these make use of den Hollandschen spraekvorm 'the Hollandic form of language' (Beredeneerd plan 1773: 2). Echoing van Iperen's complaint about Hollandocentrism, van den Bosch continued:

They, who write books in other parts and regions of the Netherlands, hesitate to use words which have not been approved of by the Hollanders, and prefer to make do with a less appropriate expression or a less fitting description, instead of daring to use a word that is common in their town or region, that is of a true Dutch origin, and that would perfectly serve their goal. ${ }^{1}$

The inclusive approach was extended to old and/or obsolete words (Beredeneerd plan 1773: 3).

Having argued for the inclusion of regional and historical forms, the Beredeneerd plan (1773: 4-6) provided an outline of both the macro- and the microstructure of the dictionary. The microstructure should comprise systematic information on the morphology, semantics, etymology, syntax and phraseology of the entries as well as sufficient examples. Furthermore, a uniform spelling was needed, at least with respect to the most strongly debated orthographical issues. The description of the microstructure was preceded by a general description of the macrostructure. The Beredeneerd plan (1773:4) argued that the dictionary should include alle de woorden welke tot de Nederduitsche tael behooren 'all the words that belong to the Dutch language'. This was then detailed as follows:

Not only the words that are understood in Holland, not only the words that occur in older or more recent or present-day books, but also all the Dutch words that are currently used in speech and in writing in Holland as well as in Zeeland, Friesland, Groningen, Overijssel, Gelderland, Utrecht, Brabant and Flanders, and have ever been used before, make up the Dutch language.

Words that are borrowed from other languages, but that have acquired, so to speak, civil rights through their being used by good writers, can be considered to be part of the Dutch language and included in our dictionary.

1. "Zy, die in andere oorden en streeken van Nederland boeken schryven, schroomen woorden te gebruiken, welke niet door de Hollanders gestempeld zyn, en verkiezen liever zich met eene mingepaste uitdrukking, of eene minvoegelyke omschryving te behelpen, dan dat zy zich van een woord zouden durven bedienen, 't welk in hun Stad of Landstreek zeer gebruikelyk is, van eenen waren Nederduitschen oorsprong, en tot hun oogmerk by uitnemendheid dienstig is" (Beredeneerd plan 1773: 3). In view of the length of many quotations in this chapter, and unlike in other chapters, I give only the translations in the main text, and the original quotations in footnotes. 
On the contrary, other words, which do not have stress on the root part, and which, as a consequence, are rightly called bastard words or city hall words, and for which we have sufficient synonyms in our language, do not have a place in our dictionary, but can be put on a separate list, if this is considered worth the effort. ${ }^{2}$

The quotation reveals the inclusive approach taken in this period, particularly with respect to the dimensions of region, mode and time. However, the approach was much less inclusive in the case of loans and loan translations. Their inclusion in the dictionary depended on the degree of integration into the Dutch lexicon. Two criteria were mentioned to judge the degree of integration. The first related to the use of good writers, which recalls the literary orientation characteristic of much of the contemporary discourse on grammar. While the target audience of language norms was gradually widened to include the population as a whole, the body of norms itself remained remarkably stable and largely dependent on a handful of literary authors (Chapter 4). The second criterion related to the stress pattern, where van den Bosch referred to the common idea that indigenous words usually had the accent on the root, not on prefixes or suffixes, which had been one of the important insights Lambert ten Kate. ${ }^{3}$

When discussing sources, van den Bosch proposed making excerpts from all Dutch books and manuscripts (Beredeneerd plan 1773: 6-8). With respect to domain, he argued for the importance of the specialised vocabulary of artists, scientists, artisans, merchants, fishermen, farmers, soldiers and so on (Beredeneerd plan 1773: 8). Furthermore, van den Bosch stated that de levende volkstaal, dat is, de spreektael der burgers en landlieden, en zelfs de straettael 'the living language of the people, that is, the spoken language of the burghers and countrymen, and even the street language' should be incorporated in the dictionary (Beredeneerd plan 1773: 8). Finally, using words reminiscent of van den Berg's, he claimed that special attention

2. "Niet alleen de woorden welke in Holland verstaenbaer zijn, niet alleen de woorden welke in oude of latere of hedendaegsche boeken voorkomen, maer ook alle de Nederduitsche woorden, welke in Holland, zoo wel als in Zeeland, Vriesland, Groningen, Overijssel, Gelderland, Utrecht, Braband en Vlaenderen, hedendaegsch in 't spreken en 't schryven gebruikt worden, en te voren ooit gebruikt zijn, maken de Nederlandsche tael uit. Woorden, welke wel van andere talen ontleend zijn, doch, door een heerschend gebruik, by goede schryveren, om zoo te spreken, hun burgerrecht verkregen hebben, kan men rekenen tot onze Tael te behooren en in ons Woordenboek te voegen. In tegendeel, andere woorden, welke den klemtoon niet op het zakelijk deel hebben, en welke, gevolglijk, met het hoogste recht, basterdwoorden of stadhuis-woorden genoemd worden, en voor welke wy in onze Tale voldoende synonima hebben, deze behooren, niet in ons Woordenboek, maer, zoo men het der moeite waerdig oordeelt, op een afzonderlyke lijst, gebracht te worden" (Beredeneerd plan 1773: 4).

3. Cf. the introduction (p. 7) to the 2001 edition of ten Kate's Aenleiding tot de kennisse van het verhevene deel der Nederduitsche sprake (1723). 
should be paid to the language of the meest-afgelegene landstreeken 'most remote areas', welke de minste gelegenheid gehad heeft om verbasterd te worden 'which have had the least opportunity to become corrupted' (Beredeneerd plan 1773: 8).

Van den Bosch was well aware of the gigantic task he had set the Maatschappij, for which reason he proposed that members of the Maatschappij adopt specific writers and/or areas, and make excerpts which would be collected and handed over to a committee that would subsequently start to work on the actual dictionary (Bereneerd plan 1773: 12-14). Nevertheless, he admitted that "the major objection concerns the possibility of this enterprise" (Bereneerd plan 1773: 10; my translation). The practical feasibility of the project is a topic that I will return to below, as it will become particularly important at the stage of the final plan around 1850 (see Section 7.6).

The Beredeneerd plan was published, together with additions and remarks, mostly by Kluit (van de Bilt 2009: 221-224). Tollius was also one of the commentators. The comments collected on 23 folios primarily concerned the microstructure of the dictionary. An important point of discussion connected to the macrostructure was whether the entries should be arranged alphabetically or both alphabetically and etymologically (van de Bilt 2009: 222). The general goal of the dictionary and the inclusive approach were not subject to discussion.

\subsubsection{The concise plan}

In the annual meeting of 1773 , the Maatschappij decided to compile a new dictionary (van de Bilt 2009: 225). Since the Beredeneerd plan had quite extensively explained its principles, a more concise instruction was needed for those members who would begin collecting lexical items (Bergman 1851-1852: 225). A committee was appointed with members such as van den Berg, van den Bosch, Kluit and Hinlópen (Bergman 1851-1852: 226). Several members of the Maatschappij agreed to excerpt old documents. Others promised to compile lists of local and regional words used in parts of Groningen, Gelderland, Overijssel, Zeeland, Brabant and Flanders (Bergman 1851-1852: 228). Van den Berg, for example, would focus on the Veluwe area in Gelderland, and van Iperen would collect "Brabantic and Flemish words that are less known in Holland" (Bergman 1851-1852: 228; my translation). It should be noted that this was not only a phase of plans, project proposals and committees. Quite a few members, including Kluit and Hinlópen, actually sent in lists of words, many of which are still kept in the University Library in Leiden (e.g. Bergman 1851-1852: 233-234; van de Bilt 2009: 232-233; see also Chapter 9).

The concise instruction was published in 1774 as the Ontwerp [...] tot het vervaerdigen van een algemeen, omschryvend woordenboek der Nederlandse tale ('Plan 
to make a general, descriptive dictionary of the Dutch language'). It comprised just over 7 folios, and was essentially a summary of the Beredeneerd plan in 27 short paragraphs, laying out the workflow. The adjectives used are still algemeen and omschryvend. An inclusive approach was taken with respect to the four variational dimensions of time, region, domain and mode. Old and obsolete, regional, specialised and spoken language would be taken into account, doch geen Basterd- of Stadhuiswoorden, welke by goede Schryvers niet gebezigd worden 'but no bastard or city hall words that are not used by good writers'. In other words, the approach was less inclusive with respect to loans and loan translations used in legal, administrative and diplomatic language.

The concise plan also contained a paragraph on the need for a list of Nederduitsche Taalgebruiken 'Dutch linguistic conventions', i.e. an inventory of grammatical forms found in varieties of Dutch. It was suggested that members who collected lexical items could also keep count of interesting grammatical items. The annual meeting of 1774 requested a more detailed explanation of this paragraph (van de Bilt 2009: 217). This request marked the transition to the following stage in the history of the dictionary plans, when objections and problems became more important and eventually led to a temporary failure of the dictionary plans.

\subsection{The first problems (1770s-1790s)}

\subsubsection{The linguistic questions}

A more detailed explanation of the Nederduitsche Taalgebruiken was presented to the Maatschappij in 1775 (van de Bilt 2009: 217). Now that the lexicological and lexicographical discussions of the preceding years had materialised in a concrete plan of action, a new and related ambition was defined, viz. het opmaken van eene volledige Grammatica der Nederlandsche Tale 'the creation a complete grammar of the Dutch language' (Taalkundige vragen 1775: 1). Members of the Maatschappij contributing to the collection of lexical items were supposed to also be aware of interesting grammatical features. In order to facilitate the selection and collection of grammatical items, the authors of the Ontwerp offered a detailed list of Taalkundige vragen 'Linguistic questions'. The list comprised 121 questions on 16 folios, preceded by four preliminary questions, the first three of which are particularly relevant here. The 121 questions mainly addressed familiar topics in contemporary metalinguistic discourse, including notorious issues such as the superfluity of the 'foreign' graphemes $\langle\mathrm{c}\rangle,<\mathrm{q}>$ and $\langle\mathrm{x}\rangle$ (questions 18, 28 and 33), the inflected forms of the verb worden 'become' (question 50), the declension of foreign, 
i.e. Latin proper nouns in accordance with Latin case forms (question 75), and the distribution of als 'as' and dan 'than' in comparative constructions (question 119). The first three preliminary questions are the following:

1. Which are the best Dutch writings, in which the linguistic conventions should be observed and from which they should be collected?

2. Can the spoken language, as used in the various regions of our fatherland, also be considered in the observation and collection of linguistic conventions? And if so, to what extent?

3. To what extent should the compilation of the language rules be informed by ancient, and to what extent by contemporary linguistic conventions? And to what extent should genetically related languages and common sense be taken into account? ${ }^{4}$

These questions signal an attitude to language and to language variation and change that is contrary to the inclusive approach advocated in the dictionary plans. The extent to which the spoken language, regional varieties and older forms should be considered is open for discussion. The first question indicates not only that the mode is crucial, but also that, within the written mode, some texts are preferable to others. As this is a text on grammar, this approach fits in well with contemporary metalinguistic discourse (Chapter 4), whereas it deviates from the lexicological and lexicographical approach that it emerged from.

The list with linguistic questions was fairly long. One consequence was that the Maatschappij never produced a coherent set of answers to the questions, although individual members made an effort to contribute to the answers (Bergman 1851-1852: 233). When Weiland published volume 1 of his dictionary in 1799, he added a lengthy introduction, with an overview of the orthography and morphology of Dutch. On the final page, Weiland said that to those who were familiar with the publications of the Maatschappij, it must have been clear that his introduction provided an answer to the linguistic questions (Weiland 1799: 196; cf. van de Bilt 2009: 217; see Section 7.4).

4 .

1. Welke zijn de beste Nederduitsche Schriften, waaruit de Taalgebruiken moeten waargenomen en opgezameld worden?

2. Kan de Spreektaal, in de onderscheiden streken van ons Vaderland, mede in aanmerking komen, in het waarnemen en opzamelen der Taalgebruiken? En zoo ja: in hoe verre?

3. In hoe verre moet men zich, in het opmaken der Taalregels, houden aan de Oude? in hoe verre aan de hedendaagsche Taalgebruiken? En in hoe verre moet men de verwantschapte Dialecten en de gezonde reden daarin te hulpe nemen? (Taalkundige vragen 1775: 2). 
Another consequence may have been that the work on the dictionary slowed down. After all, the grammar project emanated from the dictionary project, and from a strictly procedural point of view, the grammar question had to be resolved before work on the dictionary could begin, as the grammar project was part of the concise Ontwerp of 1774. Furthermore, developing two such grand projects at the same time may in itself have delayed both projects. Some of these things can only be speculated about, though it should be kept in mind that the Beredeneerd plan (1773) had already questioned the feasibility of the dictionary project.

The combination of an inclusive approach to the lexicon and a potentially exclusive approach to grammar was maintained at the stage of the linguistic questions. These wholly divergent attitudes to different parts of the language system would remain topical well into the nineteenth century (Section 7.6).

\subsubsection{A new plan}

Quite a few members of the Maatschappij sent in word lists, from 1774 well into the 1790s (Bergman 1851-1852: 233). After a few years of gathering data, in 1783, the Maatschappij installed another committee, primarily to report on the progress, a request that was repeated in 1785 (Bergman 1851-1852: 237-238). At the annual meeting of 1786, the report was presented to the Maatschappij, its main finding being that there were absolutely not enough excerpts yet to justify a preliminary publication (Bergman 1851-1852: 239). While work on the dictionary continued, important members of the Maatschappij and the committee in particular passed away (Bergman 1851-1852: 239-241). At the annual meeting of 1789, it was decided that a new committee should be formed that was to report on the progress of the dictionary project, and on the measures that should be taken to finally finish and publish the dictionary. Van den Berg, Kluit and Hinlópen were among the members of this new committee (Bergman 1851-1852: 241). Hinlópen was asked to write up a draft report (Bergman 1851-1852: 241-242). At the annual meeting of 1790 , it became clear that Hinlópen had not produced a text. At the annual meeting of 1791, Hinlópen did present his report, which had been approved by the other members of the committee (Bergman 1851-1852: 242).

Hinlópen's report, printed on 11 folio pages, was called Ontwerp tot het opstellen en bewerken van een Nederduitsch omschryvend woordenboek ('Plan for making and editing a Dutch descriptive dictionary', 1791). Hinlópen confirmed the general goal and the principles of the new dictionary, outlined in the Beredeneerd plan and the Ontwerp, but paid more attention to the method required to turn the numerous excerpts and word lists into a dictionary (cf. Bergman 1851-1852: 243). The inclusive approach is endorsed at the beginning of this new plan, where reference is made to the previous plans: 
Concerning the goal, we completely agree with the authors of that plan, and particularly with Mr. A. van den Berg. It is absolutely certain, after all, that the spoken language is older than the written language; that the latter has become hardly anything other than a special dialect of the language; that we should shy away from modeling the language after this variety, which should itself be regulated in accordance with the language. But this is part of the grammar of the language rather than of its dictionary. This remark is of the utmost importance, however, to the extent that the affluence of the language should not be sought in the written language, nor in a certain region, much less so in a particular city nor among its most polite parts; instead, in the whole country, not excluding any hamlet, the words, expressions and sayings should be investigated closely, to find everything that can serve as material during the compilation of the dictionary. ${ }^{5}$

The dimensions of region and mode, in particular, are put forward as crucial elements of the new dictionary.

As Hinlópen was requested to reflect upon the state of affairs, which had been steered by the previous plans, he also reflected upon the grammar. Hinlópen agreed that grammaticale waernemingen 'grammatical observations' were vital and should lead to a grammar of Dutch (Ontwerp 1791: 9). Interestingly, Hinlópen must have been aware of the tension implied by the inclusive approach to the lexicon, and the exclusive approach to grammar in normative discourse, which empirically tended to focus on literary writings of the seventeenth and eighteenth century, and theoretically and descriptively relied on Latin and Greek grammar models. Hinlópen reconciled these wholly divergent attitudes to different parts of the language system, which had surfaced in the linguistic questions. His proposal did not involve the extension of the exclusive approach to the lexicon, which would be the solution in the nineteenth century (see Section 7.6). Instead, Hinlópen argued that the inclusive approach should also be adopted in the case of grammar. He claimed that there were natural rules common to all languages, and that language use had led to different outcomes (Ontwerp 1791: 9). By implication, the traditional method of

5. "In het oogmerk zijn wy het volkomen eens met de opstellers van dat plan, en byzonder met den Heere A. van den Berg eens. Het is zeer zeker immers, dat de spreektale eeuwen ouder is dan de schrijftale; dat de laetste [...] byna niets anders dan eene byzondere dialect van de tale geworden is; dat wel verre van de tale naer die spraekvorme te regelen, die spraekvorme door de tale zelf behoort geregeld te worden. Dan dit behoort meer tot de spraekkunst van de tale, dan tot derzelver woordenboek. In zoo verre echter is de opmerkinge van het uiterste aenbelang, dat men in opzichte van den rijkdom der tale, niet met de schrijftale, of de tale van 't een of ander gewest, veel min van eenige stad, minder van het beschaefdste gedeelte derzelven, te rade gaen moet: maer door het gantsche land, geen gehuchtjen uitgezonderd, de woorden, spreekwyzen, uitsprake nader en nader na moet gaen, om alles op te zoeken, wat tot nadere bouwstoffe, onder het bewerken van het woordenboek, dienen kan" (Ontwerp 1791: 2). 
describing the grammar of Dutch in classicist terms, with a strong focus on nominal and verbal inflection, was wrong (Ontwerp 1791: 9-10). He cried out: Hoe verkeerd is het dan de Nederduitsche tale naer die der Latynen en Grieken te willen buigen! 'How wrong is it, then, to want to decline the Dutch language in accordance with the language of the Romans and the Greek!' (Ontwerp 1791: 10). The conclusion of his brief reflection on the grammar of Dutch reads as the inclusive alternative of the dictionary plans:

We must move away completely from the track of our grammarians. We must deduce the grammar from our own languages, abandoning the grammars of other languages. We must not use as a basis the written language only, even less so the written language of a particular city, but the whole Dutch language everywhere where it is or has been spoken and written. Particularly from farmers a lot can be learnt. ${ }^{6}$

This revolutionary proposal did not materialise. Instead, new committees were installed by the Maatschappij, and again important members passed away, including Hinlópen in 1792 (Bergman 1851-1852: 243-246). Then, while it seemed the whole plan of a new dictionary was turning into a failure, Weiland announced at the annual meeting of 1796 that he intended to make a dictionary in accordance with the Beredeneerd plan, for which he wanted to obtain the materials already gathered by the Maatschappij (Bergman 1851-1852: 246-247). The Maatschappij happily granted this request (Bergman 1851-1852: 247).

\subsection{The first publication (1799)}

Weiland published the first volume of his Nederduitsch taalkundig woordenboek ('Dutch linguistic dictionary') in 1799. The first volume comprised an elaborate introduction and the letter A. The eleventh and final volume (W-Z) came out in 1811. Weiland's dictionary depended strongly on the Dutch eighteenth-century normative tradition as well as on foreign sources, most prominently the linguistic works of J. C. Adelung, not just the Grammatisch-kritisches Wörterbuch der hochdeutschen Mundart (1774-1786), but also the grammar Umständliches Lehrgebäude der deutschen Sprache (1782; cf. Noordegraaf 1985: 176-181).

6. "Wy moeten dan ons geheel van 't spoor onzer spraekkunstenaers verwyderen; de spraekkunst, afziende van de spraekkunsten van andere talen, uit onze eigene talen opmaken: daer toe niet de schrijftale alleen, veel min die van die of die stad, ten grond leggen; maer de gantsche tale zoo verre Nederduitsch gesproken of geschreven is of wordt. Voor al is by den boer veel te leeren" (Ontwerp 1791: 10). 
The introduction amounted to 196 pages, divided between spelling (1799: 1-75) and the parts of speech (76-196). At the end, Weiland (1799: 196) said that his introduction was not intended as a complete grammar of Dutch, but only as an outline of the foundation on which his dictionary was built. In passing, he noted that his introduction provided the answers to the linguistic questions posed by the Maatschappij (Weiland 1799: 196; cf. Section 7.3).

It is striking that Weiland did not provide any clues as to what he included and excluded from the dictionary. After the introduction, the dictionary simply began with the letter A. Weiland did not explain his method nor did he present any reflections on the variational dimensions that had been important in the discussions so far. To get an idea of the extent to which these dimensions are represented in Weiland's dictionary, I carried out an explorative analysis by focusing on the first 25 pages of the letter A (Weiland 1799: 3-27). Whereas Weiland duly provides information on the parts of speech and the morphology of the entries as well as on the semantics, the five variational dimensions are only addressed sporadically. On the first 25 pages, 427 entries can be found, an average of 17 entries per page. The variance is enormous, however, with the entry aan 'on' taking over a page (Weiland 1799: 6-7), while pages $25-27$ have c. 40 entries each, all of which are past participles of prefixed verbs with aan-. These entries begin with aange-, and in most cases, Weiland merely refers to the infinitive, for example:

AANGENOMEN, verl. deelw., van aannemen.

AANGENOOPT, verl. deelw., van aannoopen.

(Weiland 1799: 25)

TAKEN, past part., of take.

ENCOURAGED, past part., of encourage.

Variation related to region, mode or domain is hardly mentioned. In 427 entries, there is one reference to regional variation. Mode is also referred to once, when a form typical of the spoken language is mentioned. This is not at all done in the descriptive manner advocated in the preceding decades, but with the condemnation familiar from the grammatical tradition (Weiland 1799: 4). Domain occurs four times in the first 25 pages, when specialised vocabulary is mentioned. In three cases, reference is made to seafaring as the domain in which a particular item is typically used. The origin of words is mentioned 13 times. In most cases, Weiland provides a tentative conclusion on the etymology of a word. References to diachronic variation occur 15 times. In most cases, Weiland merely observes that a particular word or meaning has become obsolete, expressed in phrases such as in deze beteekenis, verouderd 'obsolete in this meaning' (1799: 23) and [o]udtijds zeide men ook 'in the past, people also said' (1799: 24).

Another way to evaluate Weiland's contribution is to compare it to the model entry presented in the Beredeneerd plan of 1773 (Section 7.2). Attached to this 
initial plan of fourteen pages were two pages with a Proeve van het word varen 'Example of the word varen' (Beredeneerd plan 1773: 15-16). After having presented basic grammatical information, the model entry provides the principal parts of several Germanic cognates. Then follows a detailed description of the historical and semantic development of the verb, distinguishing primary meanings from secondary meanings, as well as of etymologically related words such as voeren 'carry' and allegedly related forms such as vervaarlijk 'dangerous'. Under the meaning reizen 'travel', it is noted that in Duitschland en in onze Provintien welke het naest daeraen grenzen 'Germany and in our provinces that are closest to it', the verb is used to refer to travelling by ship as well as to travelling by carriage. The regional variation is seemingly presented in neutral terms, yet the description feeds upon the presumed shared knowledge that the verb is only used for travel on water in western varieties of Dutch. Nevertheless, the model entry gives the impression that time and region were systematically incorporated into the analysis of varen. Furthermore, instead of ad hoc diversions of an etymological and/or comparative kind, the model entry gives systematic information on the origin and on the semantic and morphological development of the item as well as on Germanic cognates. These elements all lack in Weiland's dictionary (1799).

From the fact that the lexicographical and lexicological discussions continued in the nineteenth century, it already becomes clear that Weiland's dictionary did not satisfy all language commentators, and indeed it met with criticism from various sides (e.g. Handelingen 1851: 125-126; De Smedt 1979: 125, 128-129). The cleavage between the inclusive plans developed within the Maatschappij and Weiland's end result must have been too obvious - also to Weiland himself, who was already involved in new dictionary plans in 1809 , at a time when the final volume of his own dictionary had not even appeared (see below, Section 7.5). For its lack of inclusiveness, Weiland's plan was not the volkomen 'complete' or algemeen 'general' dictionary that had been called for since van Iperen. Although Weiland had managed to get past the stage of plans, projects and committees, it comes as no surprise that new plans were made.

\subsection{New plans (1800s-1840s)}

De Smedt (1979) shows that the first half of the nineteenth century, situated between the well-known dictionary plans of the Maatschappij and Weiland's dictionary on the one hand, and the emergence of the WNT from c. 1850 onward on the other, was not a period of lexicographical silence. Instead, new plans were developed.

In 1808, the Koninklijk Instituut van Wetenschappen, Letterkunde en Schoone Kunsten ('Royal Institute of Sciences, Languages and Arts') was founded, a national 
academy that would be transformed into the still existing Koninklijke Akademie van Wetenschappen ('Royal Academy of Sciences') in 1851. The Tweede Klasse 'Second Class' of the Koninklijk Instituut was devoted to Dutch language, linguistics and history. The Tweede Klasse had been ordered by the King to make a new Dutch dictionary (De Smedt 1979: 111). By April 1809, the second class had drawn up a report entitled Verslag betrekkelijk de inrigting en vervaardiging van het algemeen Hollandsch woordenboek ('Report concerning the design and creation of a general Hollandic dictionary', cf. Verslag 1851-1852 [1809]). The report was signed by J. W. Bussingh, the poet Willem Bilderdijk, the authors of the national spelling and grammar Siegenbeek and Weiland, and the former minister of education van der Palm. At the annual meeting of the Koninklijk Instituut later that year, from 28 August to 1 September 1809, the report was approved of, though the institute's chair remarked that to make such a general dictionary would take quite some time (De Smedt 1979: 111). In the next few years, excerpts were made and materials were gathered, as before, but a new general dictionary of the Dutch language was never published (De Smedt 1979: 111-112). After years of plans and good intentions, in October 1815 the second class of the Koninklijk Instituut officially abandoned the idea of a new dictionary (van den Berg 1999: 156).

One of the related activities of the members of the second class was the collection of obsolete words and expressions from medieval and seventeenth-century texts (Uitlegkundig woordenboek 1825: XI-XII; van den Berg 1999: 157). The works of the seventeenth-century literary author P. C. Hooft were among these texts, and between 1825 and 1838 the Tweede Klasse published the Uitlegkundig woordenboek op de werken van Pieter Korneliszoon Hooft ('Explanatory dictionary of the works of Pieter Cornelisz. Hooft') in four volumes, the only tangible result of the efforts to create a general Dutch dictionary (cf. De Smedt 1979: 112).

The Verslag of 1809 was wholly in line with the eighteenth-century plans developed within the Maatschapppij, arguing for the incorporation of old and/ or obsolete words, specialised vocabulary as well as regional items (De Smedt 1979: 112-120). The proposed title was Algemeen Hollandsch Woordenboek (cf. Verslag 1851-1852 [1809]: 323), where Hollandsch means Dutch, confirming the widespread Hollandocentrism already criticised by van Iperen (see Section 7.2). The authors adopted an inclusive interpretation of the term algemeen 'general'. They started by identifying the type of words that should be included in the dictionary (Verslag 1851-1852 [1809]: 324-326). They distinguished regional and local words, archaic and obsolete words, specialised vocabulary used by scientists, artists, artisans and so on, and loans and loan translations (basterdwoorden 'bastard words', cf. Verslag 1851-1852 [1809]: 325). Important restrictions on the inclusion of the latter were that they needed to be more or less commonly used, and moreover, unreplaceable by even verstaanbare en gebruikelijke Hollandsche woorden 'equally 
understandable and usual Hollandic words' (Verslag 1851-1852 [1809]: 326). In addition, the report argued for appendices comprising lists of the most common proper names and toponyms (Verslag 1851-1852 [1809]: 326).

In the same period, in 1809, the Tweede Klasse published a report on the acceptability of loans and loan translations, arguing for the compilation of two lists of words, the first comprising bastaardwoorden that should be kept, and the second bastaardwoorden that should be removed from the language, while offering a method to decide on the acceptability of individual items (Verslag 1809). The variational dimension related to the origin of words still constituted the greatest challenge.

Both reports produced by the Tweede Klasse were discussed by J. C. W. le Jeune in the third volume of his Bouwstoffen voor de Nederlandsche letterkunde en hare geschiedenis ('Materials for the study of Dutch literature and its history'), published in The Hague in 1835 (see le Jeune 1835: 133-195, cf. De Smedt 1979: 122-124). After having summarised the two reports, le Jeune presented his own ideas. He advocated a volledige Woordenboek der Nederlandsche taal 'complete dictionary of the Dutch language', comprising die taal in haren geheelen omvang 'this language in its entire magnitude' (le Jeune 1835: 158). These descriptions already indicate le Jeune's inclusive approach, which is even more explicit in the following quote.

Temporally, this dictionary thus comprises everything that has been part of the language, even the smallest parts, from the origin of the language onward; spatially, it comprises all the places in the Netherlands where the language has been spoken. The classical, pure language, therefore, is only a part of it. ${ }^{7}$

Le Jeune embraced the diachronic and regional inclusiveness advocated by the Maatschappij and the Koninklijk Instituut, and moreover, explicitly referred to the written mode, dominated by the literary tradition, as just one variety of the whole language.

A few years later, Constant Philippe Serrure published a short essay in a periodical published in Louvain (Serrure 1841-1842; cf. De Smedt 1979: 124-127). Like le Jeune, Serrure referred to the report made by the Tweede Klasse. Serrure, however, included a warning about the northern, Hollandic orientation of many of the existing dictionaries and dictionary plans (Serrure 1841-1842: 278-279; De Smedt 1979: 124-125). The spoken language in the southern Low Countries had remained geheel en al onbekend 'entirely unknown' to many of the northern Dutch language commentators (Serrure 1841-1842: 278). Because of this deficiency, a new general dictionary of the Dutch language should pay special attention to de tael van

7. "Naar tijdsruimte, omvat alzoo dat Woordenboek alles wat, van het begin der tale af, eenig ook zelfs 't geringste deel er van uitmaakte; naar plaatsbepaling, alle oorden van Nederland, waar zij gesproken is. De klassieke, zuivere taal is er dus slechts een gedeelte van" (le Jeune 1835: 158). 
Belgie 'the language of Belgium' (Serrure 1841-1842: 279). Given the disregard of the spoken language in Belgium, a first step would be to draw up regional and local dictionaries, so-called idioticons, which could subsequently be used as materials for the new general dictionary of Dutch (Serrure 1841-1842: 282). By way of example, the second part of Serrure's essay comprises a short Leuvensch idiotikon 'dictionary of the language of Louvain' (Serrure 1841-1842: 286-299).

De Smedt (1979: 126-127) mentions a few other Belgian language observers who alluded to the necessity of a new dictionary in the late 1830s and early 1840s. One of them was Ferdinand Augustijn Snellaert, who repeatedly argued that northern and southern linguists should work jointly on a dictionary. Some ten years later, this would indeed happen, and Snellaert played a prominent role in this.

\subsection{The final plan (1849-1852)}

The final plan for the new dictionary that would eventually become the WNT was presented in 1851 and printed in 1852 . This section will consider the final plan as well as the discussions that preceded it, focusing, as before, on the variational dimensions of time, region, mode, domain and origin. An outline of the genesis and the structure of the WNT can be found in van Sterkenburg (1992) and van Sterkenburg (2011: 159-182).

In 1849 , the plan for a new dictionary of Dutch was brought to the attention of two important institutions in the social organisation of the study of Dutch. In one of the meetings of the Commissie voor Taal- en Letterkunde ('Commission for Linguistics and Literature') of the Maatschappij, it was suggested that the Maatschappij take up work on a general, descriptive dictionary of the Dutch language. The Commissie decided that not enough material had been collected in the past so that the idea of creating such a dictionary was still premature (Handelingen 1850a: 30-32). A similar proposal was presented at the first Nederlandsch congres 'Dutch congress', which was to generate ever more concrete plans that would eventually result in the WNT. In this period, the project proposals still used terms such as complete dictionary and general dictionary.

\subsubsection{Congress 1849}

The first Nederlandsch congres ('Dutch congress', Ghent, 1849), initiated by scholars from Belgium, aimed to bring together scholars from the north and the south working on the language and literature of the Low Countries (Willemyns 1993). Between 1849 and 1912, 32 Dutch congresses were organised in a predominantly nationalistic spirit (Noordegraaf 1999: 357-358). 
At the first conference, Gerth-Van-Wijk proposed the creation of a uniform spelling and grammar of Dutch and of a complete Dutch linguistic dictionary (Handelingen 1850b: 87). The ideological background of the proposal was the desired uniformity of the gemeenschappelyke moedertael 'common mother tongue' throughout the language area, i.e. the need to standardise the spelling, grammar and lexicon of the Dutch language (Handelingen 1850b: 85). Gerth-van-Wijk's lexicographical appeal is usually considered to have been a crucial step in the genesis of the WNT (Willemyns 1993: 78).

In the discussions following Gerth-van-Wijk's wydloopige verhandeling 'elaborate lecture' (Handelingen 1850b: 85), important issues related to the aforementioned variational dimensions were raised. Snellaert, one of the organisers of the conference, wanted the congress to embrace the plan of a general, linguistic dictionary founded on de levende spraek van al de nederlandsche gewesten, zoowel als de boekentael 'the living language of all the Dutch regions, as well as the written language' (Handelingen 1850b: 88). J. A. Alberdingk Thijm also welcomed the idea, though he criticised Gerth-van-Wijk's striving for uniformity in the case of grammar and spelling (Handelingen 1850b: 89). As to the dictionary, he stated:

I wish that from the various places of the Low Countries the beautiful images and threads that constitute the Dutch language will be brought together, so that we will thus gather a treasury of the richness of our mother tongue, a museum, in which the various language forms (with the possible exception of the low idiotisms - that depends on the plan) will be listed, so that Dutch authors will know what they have at their disposal. This does not mean that they have to learn which forms should be used, but that they will become aware of what forms can be used. ${ }^{8}$

The quote is important for various reasons, one of which is that it introduced the term museum into the debate, which would become a common designator for the envisaged dictionary. Alberdingk Thijm confirmed the regional inclusiveness of the current plans, also expressed by Snellaert, while excluding what used to be called street language, i.e. coarse and vulgar language, largely restricted to informal spoken language (Section 7.2). The term low idiotisms carried with it a social meaning that would be brought to light in the following years.

Interestingly, the quote identifies a whole new target audience. The eighteenthcentury plans did not usually offer much reflection on the target audience. The

8. "ik wensch dat uit de verschillende oorden van Nederland de schoone beelden en lynen zullen by elkaêr gedragen worden, waeruit de nederlandsche tael bestaet, opdat wy aldus eene schatkamer van al de rykdommen onzer moederspraeke verzamelen, een muzeum, waerin de verschillende taelvormen (onder voorbehoud der uitmonstering der lage idiotismen - dat hangt van het plan af) zullen worden op zy gesteld; opdat de nederlandsche schryver wete waerover hy te beschikken heeft. Niet alzoo, dat hy daeruit leert wat vormen hy moet gebruiken, maer dat hy er uit zie wat vormen hem ten gebruike staen" (Handelingen 1850b: 90). 
Beredeneerd plan (1773: 2), for example, simply stated that a dictionary comprising all the Dutch words would be important to anyone interested in the Dutch language. The inclusive approach of the period appears to be mirrored by the inclusive conceptualisation of the intended readership. Alberdingk Thijm, however, had a much stricter audience in mind when he referred to de nederlandsche schryver 'the Dutch author'. Snellaert had used similar wordings. The embryonically present literary orientation would be made explicit in later years.

The congress decided that a committee should investigate the plan for a dictionary. Snellaert and Alberdingk Thijm became members of this committee. The committee members were expected to report at the next congress (Handelingen 1850b: 91).

\subsubsection{Congress 1850}

At the second Dutch congress (Amsterdam, 1850), some of the committee members shared their thoughts on the plan for a new Dutch dictionary, though Alberdingk Thijm and Snellaert did not. From this time onwards, almost all the discussions about the new dictionary revolved around the question of what to include in the dictionary, or more precisely around the question of how to make the dictionary more exclusive than implied by the still quite inclusive proposals of Snellaert and Alberdingk Thijm.

Committee member J. H. Bormans attacked the idea of generality put forward by Alberdingk-Thijm and Snellaert (Handelingen 1851: 95-110). Adopting expressions such as een algemeen idiotikon 'a general idioticon, i.e. collection of local and regional lexical items', eene schatkamer 'a treasury', een museum aller onzer gewestspraken 'a museum of all our regional languages', Bormans ironically referred to de schilderende tael 'the colourful language' of Alberdingk-Thijm (Handelingen 1851: 101), whose proposal he heavily criticised. Following up on Snellaert's and Alberdingk-Thijm's literary orientation, he made the following statement:

The literary commonwealth is inherently always more or less an aristocratic affair. Didn't Mr Snellaert - when he already so deeply offended the authority of the privileged language, of the written language, by demanding some sort of universal suffrage for all classes of words - fear that, when his principle would be adopted, barbarism and stupidity would soon occupy the whole literature? ${ }^{9}$

9. "Het lettergemeenebest is uit zijnen aard altijd iets min of meer aristocratisch. Vreesde de Heer Snellaert niet, toen hij [...] door een soort van algemeen stemregt voor alle klassen van woorden te eischen, het gezag der geprivilegieerde tael, der boekentael, reeds zo diep krenkte, dat bij aldien zijn princiep aangenomen werd, de barbarei en domheid [...] eerst-daegs de gansche letterkunde zouden overrompelen?” (Handelingen 1851: 101-102). 
In a classic gate-keeping move, Bormans contrasted the inclusive ideal with the extremely exclusive alternative of the written literary language. The attitude towards the spoken language and regional varieties as being despicable implied another problem. Bormans argued that it was generally accepted that the Dutch regional languages and Platduitsch 'Low German' on the other side of the political border had de zelfde wortels 'the same roots' (Handelingen 1851: 103). If the new dictionary was supposed to be general in terms of region and diachrony, there would be no reason for the exclusion of Low German. Instead, all the Low German snippers 'snippets', dispersed over the platdeutsche gewesten 'Low German regions' should also be collected (Handelingen 1851: 103).

J. David from Louvain was much more sympathetic to the idea of a new, general Dutch dictionary (Handelingen 1851: 111-116). He confirmed the importance of taking into account "dialectal differences living on in the mouth of the people" (Handelingen 1851: 113; my translation). What was less obvious was the importance of the diachronic dimension. David only wanted to include medieval words that were still used in one or more regions. Words that had fallen completely out of use should not be included, "as belonging to a Middle Dutch dictionary rather than to one that should present the language in its current and cultivated state" (Handelingen 1851: 113; my translation). Note that current, in the view of David, included the sixteenth and seventeenth centuries (Handelingen 1851: 113).

Prudens van Duyse embraced the idea of a general Dutch dictionary, while signalling still other categories of words to be excluded from the dictionary (Handelingen 1851: 116-123). Apart from specialised vocabulary, he made it particularly clear that the regionally varying spoken language had to be included, though not Straattaal 'street language' (Handelingen 1851: 119):

Street language, stuff of a low kind, should be rejected. We consider street language the language that is repudiated by polite, decent people, and that has no place in writings of good taste. ${ }^{10}$

Arie de Jager dwelled upon the many plans that had already been developed since the second half of the eighteenth century, within the Maatschappij and the Koninklijk Instituut (Handelingen 1851: 123-130), rhetorically concluding that some people thought these plans would never be realised. De Jager argued against the inclusive approach, and in particular, against the inclusion of historical forms, regional words and specialised vocabulary. The diachronic, regional and domain-related variation championed since van Iperen had to be reduced. Apart from the feasibility of

10. "Straattaal, als goedje van slecht allooi, zou men verwerpen. Als straattaal aanschouwen wij zulke, die door beschaafde, fatsoenlijke menschen verstooten wordt, en in schriften van smaak geene plaats kan vinden" (Handelingen 1851: 119). 
the project, the usefulness of a general dictionary was one of his main arguments against such a dictionary:

To many, the extensiveness of the work would also hinder its usefulness. The current need primarily demands a dictionary of the Dutch language, as it manifests itself in the polite spoken and written language in the regions, both Belgian and Dutch, that belong to her territory. ${ }^{11}$

For de Jager, too, the exclusion of historic forms still implied the inclusion of the writers of the Golden Age (Handelingen 1851: 128). Medieval, regional and technical words should be collected in afzonderlijke werken 'in separate works' (Handelingen 1851: 128). Later that day, de Jager would lecture about het belang van de kennis der Idiotismen onzer taal, en over hetgeen aan die kennis nog ontbreekt 'the importance of the knowledge of the regional vocabulary of our language, and about what is still lacking in this knowledge' (Handelingen 1851: 151-156). It was a powerful plea for fundamental research of regional words, which, however, did not belong in the general dictionary.

With most of the variational dimensions having been questioned, an important issue that remained was the dimension of origin, and specifically the acceptability of French loans. Michiel van der Voort from Brussels had sent in a letter on this topic, which was read at the congress and printed in the Handelingen (1851: 136141). Van der Voort argued that a general dictionary was in itself a good idea, which needed to be preceded, however, by a committee that would make an inventory of indigenous alternatives to French loans, so that the general dictionary could avoid the inclusion of French loans. The ideological position taken by van der Voort was not new, as anti-French sentiments had been very common in the Low Countries, also in the lexicographical debates (see e.g. van Iperen; Section 7.2). Van der Voort's fierce rhetoric, however, is noteworthy, with complaints about the French language having crept into the Dutch language als eene kanker 'like a cancer' (Handelingen 1851: 138).

After these strong critiques of the inclusive ideal, Alberdingk Thijm once more took the floor to defend the desired inclusiveness (Handelingen 1851: 142-151). He now took a positivistic approach, arguing that it had become common to abandon received knowledge and take a fresh look at all empirical facts available: "I wish that principle were applied to the Dutch language" (Handelingen 1851: 144; my translation). In spite of the many difficulties raised by Bormans, he continued, the

11. "De uitgebreidheid van het werk zou ook bij velen de bruikbaarheid in den weg staan. De behoefte van het tegenwoordig oogenblik eischt het allereerst een Woordenboek van de nederlandsche taal, zoo als deze zich als beschaafde spreek- en schrijftaal thans vertoont in de gewesten, zoowel belgische als noord-nederlandsche, die tot haar gebied behooren" (Handelingen 1851: 127). 
congress should lay the foundation of a Dutch dictionary, which should primarily comprise de levende elementen, die in de taal van heel het volk aanwezig zijn 'the living elements that are present in the language of the whole people' (Handelingen 1851: 144-145). As such, the dictionary should become een afspiegeling der levende volksttaal 'a reflection of the living language of the people' (Handelingen 1851: 145).

While reconfirming his inclusive ideal, Alberdingk Thijm did elaborate on two restrictions. Acknowledging the historical affinity between Dutch and Low German, he nevertheless stated that boundaries had to be drawn, and rhetorically asked why one would not do this in a more or less arbitrary manner? All borders and boundaries, are arbitrary, he continued, as High German is as close to Low German as Low German is to Dutch, and therefore:

we are making a dictionary for the people of the countries, presently separated by the names of Holland and Belgium, that can be considered to make up the Low Countries; for the Low Countries of Charles V, for the Low Countries of King Willem I; these are the Low Countries that are entitled to a dictionary, because they have established a literature of their own, a unique national character and a national culture, and therefore, having developed close connections, they can exercise their rights to a treasury of their common language more strongly than their Low German speaking neighbours. ${ }^{12}$

The Handelingen state that this part of Alberdingk Thijm's speech was applauded. Cancelling out Bormans' argument, Alberdingk Thijm embraced the idea of the Dutch language area as one cultural and ethnological space, and thus as one cultural nation. This idea was the ideological basis of the Dutch congresses, and it was only because Bormans had addressed the status of Low German that Alberdingk Thijm needed to elaborate on this restriction, which had been implied by all the dictionary plans before him.

Alberdingk Thijm adopted David's view that a diachronic boundary should be set, and that only Middle Dutch words should be included that were still used (Handelingen 1851: 148). Obsolete words should be included in a Middle Dutch dictionary, to which he now added that the congress ought to provide de natie [...] met een Woordenboek van de moderne Nederlandsche taal 'the nation

12. “wij maken een Woordenboek voor het volk van de landen, die, thands door den naam van Holland en Belgiën gescheiden, gerekend kunnen worden Nederland uit te maken; voor de Nederlanden van Karel V, voor de Nederlanden van Koning Willem I: dat zijn de Nederlanden, die aanspraak hebben op een woordenboek, omdat zij eene eigene eene eigenaardige letterkunde gevestigd hebben, eene eigene volks-characteristiek en nationale beschaving wisten te ontwikkelen, en, daardoor, in enger verbintenis met elkander getreden, hoogere rechten dan hunne plat-Duitsch sprekende geburen kunnen doen gelden op eene schatkamer hunner gemeenschappelijke taal" (Handelingen 1851: 147). 
with a dictionary of the modern Dutch language'. Note that modern here means post-medieval. This concession resulted in a temporally less inclusive approach, which Alberdingk Thijm justified by referring to the recent plan of Matthias de Vries to make a Middle Dutch dictionary, which he optimistically expected to be complete in three or four years' time (Handelingen 1851: 148). ${ }^{13}$

A main issue in the discussions was the desired degree of inclusiveness of the new dictionary. The variational dimensions of region, time, domain, mode and origin were all questioned. In the discussions, the term beschaafd 'polite, cultivated' occurred, a common term to refer to socially privileged groups, and in terms of language, to the variety used by these groups as well as to the written literary language. The word beschaafd was used by the commentators David, de Jager, and van Duyse, while Bormans took a position that was even more strongly exclusive. In the plan of 1791, devised within the Maatschappij, the term beschaefd had occurred to designate what the new dictionary should not be limited to (see above, Section 7.3). Obviously, beschaafd has a social significance that would become even clearer in the final plan, presented to the third Dutch congress of 1851.

In the eighteenth-century plans, a remarkable difference existed between the inclusive approach appropriated for the dictionary, and the exclusive approach common in normative grammar. As discussed in 7.3, this difference led Hinlópen to suggest an extension of the inclusive approach to the field of grammar in 1791. The discussions at the Dutch congress, however, would result in the other alternative, viz. the extension of the exclusive approach to the field of lexicography.

The following day, the congress accepted Alberdingk Thijm's proposal to establish a committee that would devise a detailed plan for a new dictionary (Handelingen 1851: 164, 171). The committee comprised three northern members, viz. de Vries, de Jager and H. J. Koenen, and three southern members, viz. David, Snellaert and Van Duyse. De Vries would present the final plan for a dictionary at the third Dutch congress.

\subsubsection{Congress 1851}

At the third Dutch congress (Brussels, 1851), Karel Frans Stallaert from Brussels spoke Over volkstael in spraek en schrift, met betrekking tot het ontworpen algemeen nederlandsche woordenboek ('About the language of the people in speech and in writing, with respect to the devised plan for a general Dutch dictionary', cf.

13. At the same time when de Vries was working on the WNT, he also worked on the Middelnederlandsch Woordenboek (MNW) 'Middle Dutch dictionary', which would however only appear between 1885 and 1929, largely compiled by Eelco Verwijs and Jakob Verdam (de Tollenaere 1977: 238). 
Handelingen 1852: 85-90). Referring to the discussions of the year before, Stallaert began by expressing the hope

that a free, unprejudiced, thorough and fair investigation will be the basis of the envisaged dictionary, that the language of the people will be seriously and diligently listened to, and the countless pearls of language and history that have been underestimated and called street language for too long will be shown. ${ }^{14}$

Interestingly, Stallaert's inclusive approach is primarily socially oriented. He disregarded the variational dimensions that had been central to the discussion since the 1760s, viz. region, time and domain, and focused on the social aspect, which had become more important in recent years. Stallaert's main claim was that the restriction to the language used in the Low Countries was unmotivated, and that Low German should also be taken into account. He sided with Bormans - for whom it had been an argument against the whole dictionary project - that the national border between the Netherlands and Germany should be disregarded. After Stallaert's speech, it was decided that the discussion would be postponed until the following day, which would be entirely devoted to the dictionary plans. It is obvious, however, that Stallaert's idea did not stand a chance as the congress had enthusiastically applauded Alberdingk Thijm's statement that the dictionary should serve the Dutch language area only.

The next day, Matthias de Vries presented the final dictionary plan that laid the foundation of the WNT, viz. the Verslag der commissie, benoemd door het Tweede Nederlandsch Letterkundig Congres, tot het beramen van maatregelen ter zamenstelling van een Woordenboek der Nederlandsche Taal ('Report of the committee, installed by the second congress on Dutch language and linguistics, to take measures for the compilation of a dictionary of the Dutch language', cf. Handelingen 1852: 109-155). The Verslag was written by de Vries, after he had received valuable input from the other committee members (Handelingen 1852: 113). At the very outset, the Verslag made clear what the rationale behind the dictionary plan was, with allusions to the cultural and ethnological space defined by the language area that covered most of the Netherlands and Belgium:

Gentlemen, members of this congress,

For the third time, brothers of kin and language fellows have flown together from various parts of the southern and northern Netherlands, to strengthen the ties that entwine all by unity of descent through personal acquaintance; to discuss with

14. "dat een vry, onbevooroordeeld, grondig en eerlyk onderzoek, het bedoelde woordenboek zou ten gronde gelegd worden, dat men zich ernstig zou bevlytigen met het afluisteren der volkstael, met het opbeuren van die ontelbare tael- en geschiedkundige peerlen, die al te lang onder den schimpnaem van straettael miskend worden" (Handelingen 1852: 85). 
each other issues of a common national importance; to inspire, through mutual contact and encouragement, the enthusiasm of all to work harmoniously together for the cause of the Dutch nationality. For the third time, a topic is brought up in this brotherly meeting, which is more than any other topic very closely connected to this nationality, and which can ascertain the enduring unification of South and North in the field of language and literature more strongly than anything else: the compilation of a general Dutch dictionary. ${ }^{15}$

De Vries continued by claiming that "the Dutch nation has an urgent need for a dictionary" (Handelingen 1852: 113; my translation). Note that he still used the label algemeen 'general'. In what follows, it will become clear that national and general were given a meaning very different from the inclusive ideal advocated in many of the previous plans. Taking stock of the various objections raised in the discussions at the congresses of 1849 and 1850, de Vries developed a distinctly exclusive idea of generality and nationality.

The Verslag discussed three issues (Handelingen 1852: 113-114): what should be included in the dictionary (the contents), how it should be included (the design), and how the dictionary should be produced (the workflow). The main decision with respect to the manner of inclusion, i.e. the design of the dictionary, was the order of the entries, which would be alphabetical, and within the entries, etymological (Handelingen 1852: 135). The actual production of the dictionary primarily concerned practical matters such as the appointment of editors, the division of labour between them, and the necessary coordination of their results (Handelingen 1852: 144).

The most crucial problem was the first one: what to include? What were the desired contents of the new dictionary? De Vries showed himself to be very aware of the issues involved. He first argued that the topic of any scholarly work depended on its goal (Handelingen 1852: 114). In the case of a dictionary of Dutch, this goal could be of ruimer ò beperkter 'either more broad or more restricted' (Handelingen 1852: 114). The broader end goal would comprise

15. "Mijne Heeren, Leden van dit Congres, Ten derden male zijn uit verschillende oorden van Zuidelijk en Noordelijk Nederland stambroeders en taalgenooten te zamen gevloeid, om door persoonlijke kennismaking den band, die allen door eenheid van afkomst omslingert, naauwer toe te halen; om met elkander te beraadslagen over vraagstukken van gemeenschappelijk vaderlandsch belang; om aller geestdrift door onderlinge wrijving en aansporing te bezielen tot eendragtige zamenwerking voor de zaak der Nederlandsche nationaliteit. Ten derden male wordt in deze broederlijke bijeenkomst een onderwerp te sprake gebragt, dat meer dan eenig ander met die nationaliteit in het allernaauwste verband staat, dat krachtiger dan iets anders de duurzame vereeniging van Zuid en Noord op het gebied van taal en letteren kan verzekeren: de zamenstelling van een Algemeen Nederlandsch Woordenboek" (Handelingen 1852: 109). 
the language, in the most extensive meaning of the word, in its history from the earliest times onwards until the present day, in all the stages of its manifold development $[\ldots]$. The boundaries of time and place that should be set for such a work are none other than those in which the language itself is enclosed, chronologically and geographically. All the words and expressions that can be found in Dutch writings in a period of now seven centuries find their place there; nothing that testifies to the inexhaustible affluence of our mother tongue in any village or hamlet may remain unused: everything that was ever or anywhere Dutch must be collected, arranged and made into a complete whole. In short, it should be a treasury of the language, a 'National Museum of Language Forms.' ${ }^{16}$

De Vries here clearly recalled the earlier, inclusive plans. However, this was not de Vries' plan. He continued:

The opposite of this grand and much-encompassing plan is another plan of a more limited scope. It does not represent the language in the complete history of its development, but to the degree that this development has presently reached. It is not meant to satisfy all demands according to the most undefined generality, but it aims exclusively at the well-defined needs of the polite public with an interest in language and literature. Therefore, it is confined to fixed boundaries, and proportional to these needs. Everything that is swallowed up by the stream of time and only belongs to far-off days cannot be included here, nor can everything be permitted that is not of general but only of regional or local importance, nor what exclusively belongs to the circle of the lower orders, but goes against the usage of the polite people. The present-day language in its polite state: behold the more restricted field to which the lexicographer limits himself here. ${ }^{17}$

16. "de taal, in den uitgebreidsten zin des woords, in hare geschiedenis van den vroegsten tijd af tot op heden toe, in alle trappen harer veelzijdige ontwikkeling [...]. De grenzen van tijd en plaats, voor zulk eenen arbeid te stellen, zijn geene andere dan die waarbinnen de taal zelve, chronologisch en geographisch, besloten is. Alle woorden en spreekwijzen, die men in Nederlandsche geschriften aantreft in een tijdvak van nu zeven eeuwen, vinden daar hunne plaats; niets wat in eenig dorp of gehucht getuigenis geeft van den onuitputtelijken rijkdom onzer moedertaal, mag ongebruikt blijven: alles wat ooit of ergens Nederlandsch was, moet daar verzameld, gerangschikt en tot een volkomen geheel bearbeid worden. Kortom, het moet eene schatkamer der taal, een 'Nationaal Museum der Taalvormen' zijn' (Handelingen 1852: 114).

17. " $\mathrm{t}]$ egenover dit grootsche en veelomvattende plan staat een ander van meer beperkten omtrek. Het vertegenwoordigt de taal niet in de volledige geschiedenis harer ontwikkeling, maar in den graad, welken die ontwikkeling heden ten dage bereikt heeft. Het is niet bestemd, om in de onbepaaldste algemeenheid alle eischen te bevredigen, maar het rigt zich bij uitsluiting tot de bepaalde behoeften van het beschaafde letterkundige publiek. Daarom is het binnen vaste grenzen besloten, aan die behoeften evenredig. Wat, in den stroom des tijds verzwolgen, slechts tot de vervlogene oudheid behoort, kan hier niet worden opgenomen, en evenmin kan al datgene worden toegelaten, wat niet van algemeen, maar slechts van gewestelijk of plaatselijk belang is, 
This passage outlines de Vries' idea of the contents of the new dictionary. It also reveals the transformation from inclusiveness to exclusiveness anticipated at the Dutch congresses of the preceding years. De Vries criticised the inclusive concept of generality advocated since van Iperen for being onbepaald 'undefined', and he drew firm boundaries instead. Historical and obsolete forms should be excluded, likewise regionally and locally bounded forms.

The passage is highly relevant as it discloses the social significance of the variational dimensions discussed in the dictionary plans. As mentioned above, the social as a demarcating category only became important through the use of terms such as beschaafd at the Dutch congresses. In the eighteenth- and early nineteenth-century dictionary plans, the social had been virtually absent, in line with the ideal of inclusiveness. Here, however, de Vries elaborately commented upon the various possibilities to render the dictionary more exclusive, and this brought in the social dimension. Apart from obsolete and regional/local vocabulary, lexical items used by the lower ranks should also be excluded. Street language had been discussed since van Iperen, and the concept itself has a social side (Section 7.2). De Vries, however, was not referring to the informal, spoken language, but in a much more general way to socially conditioned lexical variation. He confirmed the importance of beschaafd 'polite' as a crucial category, as well as the literary orientation present already in Alberdingk Thijm's contribution to the first Dutch congress. Contrary to the earlier projects that had been aimed at the Dutch public in general, the target audience of the new dictionary was reduced to encompass the upper and upper-middle ranks, the polite public with an interest in language and literature.

After having discussed the inclusive and the exclusive approach, de Vries argued that the choice between het ideaal 'the ideal' and the other, exclusive option was a matter of 'practical concern: what is feasible in the present?' (Handelingen 1852: 115). He referred to de Jager, who had argued that the knowledge of regional varieties was not yet sufficient (see 7.6.2). De Vries added that this also applied to historical varieties (Handelingen 1852: 116-117). Another practical problem was the spelling: should historical and regional forms be moulded to fit the national spelling system, or should varying uncodified spelling systems be adopted to represent historical and regional forms as a consequence of which the dictionary would be an orthographical hotchpotch? Neither option was to be preferred (Handelingen 1852: 117).

of wat uitsluitend tot den kring der lagere volksklasse behoort, maar tegen het gebruik der beschaafden aandruischt. De tegenwoordige taal in haren beschaafden toestand: ziedaar het engere veld, waarbij zich hier de lexicograaf bepaalt" (Handelingen 1852: 114-115). 
Still another problem was that an inclusive dictionary, albeit een heerlijk gedenkstuk voor onzen nationale roem 'a magnificent memorial for our national glory' (Handelingen 1852: 117), would not satisfy the most urgent needs of the public with an interest in language and literature (Handelingen 1852: 117-118). It would be too voluminous and too expensive to become the linguistic source with which the whole nation could slake its thirst (Handelingen 1852: 118). Yet a national dictionary was what was needed, as he explained in the following passage.

Amid the corruption with which ignorance and lack of taste constantly threaten the language; with the contamination that finds its way in across the borders every day; with the general insecurity in so many matters of language and style - nothing is so urgently necessary for the polite public as a practical and useful dictionary; not to force decisive laws with supreme authority, not to impede free choice, but to display, completely, clearly and in an orderly manner, the treasures that can be used in such choices. And who of you does not understand how many beautiful fruits to be used for the refinement of the Dutch style, in poetry as well as in prose, will originate from such a collection? ${ }^{18}$

Here, de Vries' literary orientation is even clearer than before. The new dictionary should not only be a treasure trove for the polite public, but also for future authors. In addition, he made a reference to loans from other languages, i.e. to the variational dimension of origin.

The conclusion of this part of the Verslag was that the new dictionary should be limited to de tegenwoordige taal, gelijk zij zich vertoont in het algemeene gebruik der beschaafden 'the present-day language as it shows itself in the general usage of the polite people' (Handelingen 1852: 118). After having rejected almost all of the variational dimensions that had been important since van Iperen, and after having abandoned the idea of inclusiveness altogether, de Vries still held on to generality as a defining characteristic of the dictionary. But general and national had acquired a wholly different meaning. Diachronic and regional variation no longer featured. The literary orientation put the spoken language in a poor light. Finally, there was a

18. "Te midden der verbastering, waarmede de onkunde en wansmaak telkens de taal bedreigen; bij de besmetting die dagelijks van over de grenzen binnendringt; bij de algemeene onzekerheid in zoo menig punt van taal en stijl, is voor het beschaafde publiek niets zoo dringend noodzakelijk als een praktisch en bruikbaar Woordenboek: niet om met oppermagtig gezag beslissende wetten op te dringen en de vrije keuze te belemmeren, maar om, volledige, ordelijk en duidelijk, de schatten ten toon te spreiden, waarover men bij die keuze kan beschikken. En wie Uwer ziet niet in, welke schoone vruchten voor de veredeling van den Nederlandschen stijl, in poëzij zoowel als in proza, uit zulk eene verzameling zouden ontspruiten?" (Handelingen 1852: 118). 
distinctly social aspect that led to a reduction of both the 'national', 'general' Dutch lexicon itself and the target audience of the dictionary to what was considered to be, in one word, beschaafd 'polite'.

Still, the next part of the Verslag softened this entirely exclusive approach (Handelingen 1852: 118-121). Obsolete forms may live on in the language of a small circle of people, or are used by een smaakvol dichter 'a tasteful poet' (Handelingen 1852: 119), or their meaning immediately becomes clear from the context. Moreover, the dictionary should be eene afspiegeling zijn van de letterkunde, die de taal beschaafde en veredelde 'a reflection of the literature that cultivated and refined the language' (Handelingen 1852: 119), and this literature is in part a historical literature. As a consequence, the dictionary should reach back to the Golden Age of Dutch literature (see Chapter 5). In the original plan, the Verslag, de Vries set the terminus post quem at 1637, when the official Bible translation was published. Already in 1854, when de Vries reported on the progress of the dictionary work to the fourth Dutch congress, he explained that the terminus post quem had been shifted back in time to 1580 in order to include the best of the Dutch literature of the Golden Age (Handelingen 1855: 209-210; de Vries 1882: XL), completely in line with de Vries' strongly literary orientation (van Sterkenburg 1992: 28). De Tollenaere (1977: 232) remarks that the WNT was originally characterised by a certain degree of literair estheticisme 'literary aestheticism'. A similar exception should be made, according to de Vries, when it is uncertain whether a word is regional or general. In such cases, a liberal policy should be adopted (Handelingen 1852: 121).

De Vries' position vis-à-vis the spoken language is more complicated. With his literary orientation, both in terms of resources and target audiences, an interest in the spoken language seems less obvious. Nonetheless, de Vries argued that the gap between the spoken and the written language should be bridged, and that the aim was not to create a Dutch counterpart of the dictionary of the Académie française, i.e. a prescriptive dictionary hailing the formal and literary written language, and neglecting the spoken language (Handelingen 1852: 121-122). Quite the contrary, the spoken language should be investigated, he continued (Handelingen 1852: 122). But the argument was intricate. De Vries criticised the dry spirit of much of the written language, for which the pejorative term boekentaal 'lit. book language, bookish language' was used, and complained that it made het volk 'the people' lose their interest in writings (Handelingen 1852: 122). The language spoken by the people (gesprokene volkstaal), on the other hand, was lively, casual and charming, and should be used to give the written language een meer echt Nederlandsch karakter 'a more truly Dutch character' (Handelingen 1852: 122). Invoking the Romantic idea of the unspoiled and spontaneous people, their language forms should be used to enhance the boekentaal. In other words, the rapprochement of the spoken and the written mode was eventually required 
to improve the written language, and did not reveal the need to investigate the spoken language per se. ${ }^{19}$

Beside this fairly instrumental view of the spoken language within an approach focused on so-called polite language, particularly on the literary language, de Vries also abandoned so-called street language, i.e. indecent language, which he saw as a part of the language of the people that was to be avoided (Handelingen 1852: 122). The interwovenness of the linguistic and the social is apparent here. It is not just a lexicographical decision to exclude coarse language. In de Vries' idea of sociolinguistic space, coarse language is a subvariety of the spoken language that does not exist in the polite language of polite people.

De Vries also discussed the dimensions of genre and origin. Specialised vocabulary should be included in the new dictionary, provided it was not restricted to certain regions and had not become obsolete (Handelingen 1852: 124-125). His approach to loans and loan translations was wholly different, and in particular much less tolerant. Specialised vocabulary was often of foreign origin, and he advocated the importance of echte vaderlandsche kunstwoorden 'truly national technical words' (Handelingen 1852: 126). He also accepted loans that had become integrated into the Dutch grammar morphologically and/or prosodically (Handelingen 1852: 128129). He fiercely criticised, however, the barbarismen:

words made from Dutch components but in imitation of foreign languages and adverse to the laws of our language. It is from this side that the purity of the language is threatened most strongly, infinitely more than from numerous words borrowed from foreign languages without any changes. The Latinisms of past times, the Gallicisms and Anglicisms of our days, but above all the immeasurable army of Germanisms: behold enemies who require a ceaseless guarding and battling. If one appreciates a pure, truly Dutch style, if one wants to honour the language as a mirror of the entire people, well, then one should keep a close watch on the dictionary that should remain closed to these foreign elements that are creeping in. Indeed, we think that even this will not suffice. It is not enough to evade the enemy: he should be pointed out to everybody so that they will be on their guard in time. That is why we propose not only to keep the dictionary free from all barbarisms, but also, as a specific warning, to place an alphabetical list of the most frequent barbarisms at the back, supplied also with the words by which they could and should be replaced in good Dutch. ${ }^{20}$

19. De Vries' supposed interest in the spoken language, expressed in other writings too, was criticised by some contemporaries for being restricted to a specific kind of spoken language, i.e. the so-called polite language (cf. e.g. van Driel \& Noordegraaf 1998: 150-151).

20. "woorden uit Nederlandsche bestanddeelen, maar in navolging van vreemde talen en strijdig met de wetten der onze, gevormd. Het is van dien kant, dat de zuiverheid der taal het meest gevaar loopt, oneindig meer dan van tallooze woorden, onveranderd aan vreemde talen ontleend. 
De Vries was a fierce purist (van Sterkenburg 1992: 28), who embraced a discourse of battle and war to fight foreign elements in the language, especially when they traveled incognito. Only easily identifiable loans were permitted, as they could not be mistaken as truly Dutch. The variational dimension of origin led de Vries to adopt an extremely exclusive approach: he advocated the use of a separate list of barbarismen and their Dutch alternatives.

De Vries' plan met with great support (Handelingen 1852: 156-157). His plan was approved, and an editorial board was created, in which de Vries would play a central role (van Sterkenburg 1992; van Driel \& Noordegraaf 1998).

\subsubsection{Volume I of the WNT (1882)}

In 1864, the first issue of the WNT was published (from $a$ to aanhaling). The first volume came out in 1882 (a-ajuin; van Sterkenburg 1992: 91). De Vries wrote a lengthy introduction to the first volume, in which he explained the design and the contents. Large parts of this introduction repeat the plan presented in 1851. De Vries also returned to the concept of generality underpinning the WNT, and thus to the five variational dimensions. He emphasised that algemeenheid 'generality' should not be taken in an absolute sense, temporally nor geographically (de Vries 1882: XXXVII). An absolutely general dictionary would be een heerlijk ideaal 'a delightful ideal', but given the lack of knowledge of historical stages of the language and of regional varieties, to strive for such a dictionary would be eene dwaasheid 'foolishness' (de Vries 1882: XXXVII). In addition, an absolutely general dictionary would not meet the needs of the audience. Readers would need quite some knowledge of Dutch to find their way in such an elaborate dictionary, and most of them would become confused (de Vries 1882: XXXVIII). It would be a treasure trove for the learned, but not a spring that would enable everybody to drink in the language, which was, however, wat de natie verlangt 'what the nation desired' (de

De latinismen van vroegeren tijd, de gallicismen en anglicismen van onze dagen, maar bovenal het onmetelijk heir der germanismen: ziedaar vijanden, waarbij een onophoudelijk waken en strijden vereischt wordt. Stelt men prijs op een zuiveren, echt Nederlandschen stijl, wil men de taal in eere houden als de afspiegeling van het geheele volk: welaan, dan blijve het Woordenboek voor die vreemde inkruipsels met het scherpste toezigt gesloten. Ja, zelfs hiermede achten wij niet te moeten volstaan. Het is niet genoeg den vijand te ontwijken: hij moet aan iedereen worden aangewezen, opdat men bij tijds op zijne hoede moge zijn. Daarom slaan wij U voor, niet slechts het Woordenboek van alle barbarismen vrij te houden; maar, ter bepaalde waarschuwing, eene alphabetische lijst van de meest voorkomende achteraan de plaatsen, met opgave tevens van de woorden, waardoor zij in goed Nederlandsch kunnen en moeten vervangen worden" (Handelingen 1852: 129). 
Vries 1882: XXXVIII). Therefore, the general Dutch dictionary was restricted to 'the living language in its polite state' (de Vries 1882: XXXVIII).

In the course of his career, de Vries had embraced an empirical approach to language that he confronted with a normative approach, an opposition resembling the difference between linguistics and philology, and, in contemporary metaphors, the difference between the botanist and the gardener (Noordegraaf 2015: 128-131). In the introduction to the first volume of the WNT, he explicitly stated that both perspectives had been incorporated (de Vries 1882: LXXX-LXXXI). The scientific perspective had led to the study of the spoken language of the people, while the normative perspective had focused on the polite and literary language. Again, however, he made clear that the convergence of the spoken and the written language was mainly in the interest of the further advancement of the polite, written language, which he considered to be de afspiegeling en de kracht der nationaliteit 'the mirror and the strength of the nationality', whereas the volksspraak 'spoken language of the people' was the mirror and the strength of het individueele leven 'individual life' (de Vries 1882: LXXX). He thus invoked another variational dimension justifying his exclusive preference for the written language: the spoken language, particularly the impolite, localisable spoken language of the people, was apt for personal communication, though not for the supra-individual representation of the nation.

\subsection{Final remarks}

The general development of the dictionary plans in the eighteenth and nineteenth centuries runs from fairly inclusive to fairly exclusive. Inclusiveness with respect to domain, i.e. specialised vocabulary, was criticised, but eventually de Vries' plan for the WNT tolerated technical language to a certain extent. Exclusiveness was the key term in the case of contact-induced lexical changes. Throughout the period, the status of loans and loan translations was highly insecure, resulting in de Vries' rabid purism. In the case of mode, the inclusive approach was replaced by an exclusive approach. The earlier interest in the spoken language made way for a primary focus on the written language, in particular literary language. The importance of the spoken language was furthermore reduced to the emphasis on polite language, which not only excluded so-called street language for most commentators, but which also introduced an explicitly social aspect into the discussion. The Dutch lexicon was no longer the collection of lexical items produced by speakers of Dutch, but the polite lexical items produced by polite people. The two most heavily debated variational dimensions, viz. diachrony and region, displayed a similar change from inclusiveness to exclusiveness. Gradually, the Dutch lexicon became more restricted in temporal and geographical respects. This was sometimes justified on the basis of 
practical concerns, but it is obvious that in the case of an enormous project only the act of choosing itself can be termed practical. The actual choices are intrinsically motivated and, in the present case, reveal language ideological positions.

What then is Dutch? What is the Dutch lexicon? What is the national language, a general dictionary? These terms can refer to very different concepts. In the prototypical Enlightenment spirit of universalism, the first dictionary plans conceptualise the Dutch language and its lexicon in a remarkably inclusive way. In the course of time, and in particular in the 1840s and 1850s when the WNT is debated, Dutch becomes more limited, referring primarily to the written language and the so-called polite spoken language modeled after the western Dutch writing tradition, i.e. the variety that also formed the basis of the normative grammatical tradition. Despite the increasing restrictions on the concept of Dutch, however, the generality, and later nationality of the dictionary projects was never questioned. In other words, both historical and contemporary language users and the lexical items they used that were initially included in the idea of generality were later excluded from it as well as from the idea of nationality. The most pervasive social consequence was that speakers of dialects and of so-called impolite language were not considered part of the Dutch nation. 


\section{Standard language linguistics}

\subsection{Introduction}

Chapter 7 discussed the nationalisation of the lexicon between the 1760s and the 1850s. The same period also saw the rise of Dutch studies as a scholarly discipline, more or less coterminous with the rise of English studies and German philology (e.g. Palmer 1965; Meves 2011). Grammar and spelling became major focal points within Dutch studies. Importantly, the study of grammar and spelling was strongly biased toward the written language, particularly the literary tradition of the seventeenth and eighteenth centuries. Thus, the new academic discipline of Dutch linguistics entailed in principle standard language linguistics, feeding on the discursive split of the sociolinguistic continuum into standard and non-standard (Chapter 2). In so far as non-standard language became part of metalinguistic discourse, it was limited to a discussion of non-standard lexical items within a folklorising framework (Chapter 9).

The Dutch tradition of normative grammar and, more generally, metalinguistic discourse dates back to the sixteenth century. Eighteenth-century metalinguistic discourse was characterised by a gradual development towards a wider target audience, which was however halted, to some extent, with Weiland's (1805a) official grammar, as this embraced the early eighteenth-century, elitist approach to morphology (Chapter 4). In addition to the ongoing publication of normative grammar books, the second half of the eighteenth-century also witnessed two important developments in the formation of Dutch studies as a scholarly discipline.

First, metalinguistic discourse became part of the widespread semi-public debates and publications initiated by learned societies. As a result, many periodicals issued by these societies comprised texts about language. The new professors of Dutch appointed throughout the Netherlands in the first half of the nineteenth century were often recruited from the societal networks, and the academic discipline of the early nineteenth century fed on the periodical publications of the previous decades. Section 8.2 presents an analysis of the metalanguage found in a range of periodicals from this period.

Secondly, the formation of the discipline of Dutch studies saw various moments of academic institutionalisation. Matthijs Siegenbeek has long been considered the first professor of Dutch, taking up a position as extraordinary professor of Dutch 
rhetoric at Leiden University in 1797. In 1799, his extraordinary chair was changed into a regular chair. Siegenbeek subsequently took up the responsibility of authoring the first official spelling (Siegenbeek 1804a). He remained in office until 1844, and was a central cultural agent in the first half of the nineteenth century. As it is impossible as well as unnecessary to discuss all leading figures in the field of Dutch studies, I will focus on Siegenbeek's publications in Section 8.3.

There were probably, however, professors teaching Dutch at university level before Siegenbeek was appointed. Meinard Tydeman was the author of two seminal essays, written in 1761 and 1762, that dealt with the importance of a national 'mother tongue' and the need to impose this on a nationally organised education system (Section 2.3). In 1764, Tydeman took up a chair in history, rhetoric and Greek at the University of Harderwijk (Noordegraaf 2012: 90). In his 1765 inaugural address, he repeated his arguments in favour of the cultivation of the national vernaculus sermo 'native tongue' (Noordegraaf 2012: 90). Tydeman also planned to teach Dutch grammar, possibly on the basis of Verwer (1707), but in view of his departure to Utrecht, where he was to become professor of law in 1766, he probably never actually taught Dutch at university level (Noordegraaf 2012: 91-92).

Tydeman's successor in Harderwijk was Herman Tollius, whose intention to teach on the purity of Dutch was approved in 1773 (de Bonth in Tollius 2007: IX-X, XVI-XVII). He taught his course in 1773, possibly also in 1774, to students of law and theology (de Bonth in Tollius 2007: XVII). Several lecture notes have been preserved as well as a manuscript grammar written by Tollius himself in the same period (de Bonth in Tollius 2007: XVIII-XXX). The grammar, well rooted in the eighteenth-century metalinguistic tradition, remained unpublished until de Bonth's edition in 2007.

In 1790, Everwinus Wassenbergh, who had been professor of Greek at the University of Franeker since 1771, asked permission to teach a course in Dutch language and literature, which was granted by the Board of Curators (Noordegraaf 1997: 15). It remains unclear whether Wassenbergh actually started teaching Dutch in 1790, but he did from 1797 onward, when his teaching commitment was officially extended to include Dutch, to which several retained lecture notes testify (Noordegraaf 1997: 16, 19-22). Interestingly, Wassenbergh used the 1793 grammar by van Bolhuis (Noordegraaf 1997: 21), adopted by the Maatschappij tot Nut van 't Algemeen 'Society for Public Advancement', but considered too difficult for the use in schools (Section 2.5), despite the fact that van Bolhuis took great effort to render the grammar of Dutch more accessible, representing a crucial step in the development of so-called national grammar (Section 4.5).

Lambertus van Bolhuis was a minister in the city of Groningen from 1786 to 1823 (Noordegraaf 2004b). When he died in 1826, Siegenbeek wrote a short biography in which he stated that van Bolhuis, "driven by a desire for the honour of 
the language of the fatherland", had taught Dutch to students at the University of Groningen during his first years there, after which he turned to teaching "the foundations of the language" to schoolteachers (cf. Siegenbeek [1827]: 9-10; my translation). Teaching Dutch to university students was taken over by Johannes Ruardi, professor of classical languages at Groningen University, who probably taught a Dutch course from 1795 onward (Siegenbeek [1827]: 10; Noordegraaf 2004b).

There had been precedents, in other words, when Siegenbeek was inaugurated in 1797. Still, his appointment remains a landmark as his chair was the first to be devoted solely to Dutch (cf. Vis s.d.: 10). In England, dedicated chairs in English studies were first established in London in the 1820s and 1830s (Palmer 1965: 18-19). However, the study of English was already an academic topic in Scotland, notably in Edinburgh, where it was taught by Adam Smith and Hugh Blair as early as the eighteenth century (Momma 2013: 154).

Siegenbeek's position would continue to be unique for almost twenty years. After the creation of the United Kingdom of the Netherlands (1815-1830), which temporarily brought together the southern and the northern parts of the Low Countries, King William I decided to pursue a nationalist language policy. The policy also included the installation of professorships of Dutch literature and rhetoric throughout the newly created country, both at universities and at other institutions of higher education in a few important cities, notably the so-called athenaea in Amsterdam and Deventer (i.a. Vis 1992; Janssens \& Steyaert 2008). In the next few years, this led to appointments in Groningen, Utrecht, Amsterdam, Deventer, Ghent, Liège and Louvain. The main task of these professors was to offer students of law and theology a solid background in Dutch language and literature. Only from 1876 onwards, when a new law on higher education was passed, could Dutch programmes offer doctorate degrees (Hulshof, Kwakernaak \& Wilhelm 2015: 197).

At the University of Groningen, B. H. Lulofs became an ardent supporter of a Dutch national culture, in which the seventeenth-century poet Vondel embodied literary and linguistic perfection, recalling in many respects the approach taken by Siegenbeek (see Section 5.3.2 and Petiet 2018; cf. Section 8.3). Similarly, J. M. Schrant at the University of Ghent followed in the footsteps of Siegenbeek (see 5.3.2 and Weijermars 2009), as did A. Simons in Utrecht (Honings 2018). Nationalist activities were also employed by J. Kinker at the University of Liège, particularly within the student society that he hosted at his home (van der Wal 2018). In his regular teaching, he strongly relied on Weiland's official grammar of 1805a (van der Wal 2018). G. J. Meijer in Louvain and J. P. van Capelle in Amsterdam also fit into the general description of the first generation of professors of Dutch offered by Vis (1992, s.d.): they put a strong emphasis on rhetoric, conceived the study of language and literature as an inseparable unity, justified Dutch studies with an 
appeal to nationalist ideology, and generally considered the seventeenth century to have been the Golden Age of Dutch national culture (see also 5.3.2).

The importance of rhetoric within the university programme of Dutch studies is intrinsically linked to one of the key functions of contemporary universities, viz. to train ministers and lawyers (Vis 1992: 79; Weijermars 2009: 7-8). In addition, most of the first academics specialising in Dutch studies assumed "an unbreakable coherence of the study of language and literature" (Vis 1992: 80; my translation). They worked in the interest of a national culture, considering Dutch studies to be an important contribution to the development of such a culture. The approach to language, literature and rhetoric was usually historical, and it is not surprising that national history was often also part of the job description. From 1815 onwards, for example, Siegenbeek's teaching remit included vaderlandsche geschiedenis 'history of the fatherland'. The justification of this approach was based on a specific cultural model, implying that the study of the history and culture of the fatherland deserved to be represented at university level. Thus, the justification was wholly embedded within a nationalist ideology. Culture, in this respect, primarily referred to literature and rhetoric. Linguistics mainly comprised knowledge of the pure mother tongue and its history. The combination of these principles led to course materials consisting of historical overviews of Dutch literary and rhetorical masterpieces, resulting in a fairly fixed canon in which the seventeenth-century Golden Age figured as the point de la perfection (Section 5.3). A cyclical model of the rise and fall of the Dutch nation was adopted, in which cultural developments were bound up with socio-political and economic developments. In general, the seventeenth-century Golden Age was only equalled by the contemporary period, in which a new stage of blossoming followed the temporary cultural decline of the late seventeenth and the eighteenth century (Wiskerke 1995; Vis s.d.; Honings, Rutten \& van Kalmthout 2018).

The rise of Dutch studies as a scholarly discipline is an interesting case for theories of discipline formation. My approach ties in with Johannes' $(2011,2015)$, who argues that the process of discipline formation in the case of so-called national philologies challenges many generalisations in the literature on scientific discipline formation, particularly in the following two respects. First, the formation of the discipline is not characterised by ongoing specialisation and differentiation. On the contrary, Dutch studies was a very general field of knowledge, feeding on a long tradition of the interwovenness of the study of language and literature, and even becoming more general in the late eighteenth and early nineteenth century, when rhetoric and national history were incorporated into Dutch studies. Secondly, discipline formation in this particular field of knowledge was not an internal or autonomous process, depending solely on the dynamics of the field or on the scholars themselves. Instead, cultural and socio-political transformations were decisive: in 
more general terms, the rise of cultural nationalism was a dominant ideology, and specifically, with the top-down efforts to establish professorships. ${ }^{1}$

The professors appointed from 1815 onwards could rely on a considerable body of work carried out by their predecessor Siegenbeek as well as by Weiland, whose 1805 grammar had been officialised, after all, and therefore constituted a main point of reference for their courses on Dutch linguistics. In addition to the normative tradition, to which Siegenbeek and Weiland were immensely indebted, another point of reference was the explosion of metalanguage in the new genre of the periodical from the second half of the eighteenth century onwards, which is the topic of Section 8.2.

\subsection{Dutch studies in periodicals}

The eighteenth century saw the rise of societies as the central form of social and cultural organisation, and concomitantly the rise of periodicals or journals as main outlets for literary production and scholarly discussion. In this section, I will briefly discuss the main trends in a range of major periodicals that included linguistic topics.

There were, of course, also periodicals focused on wholly different topics such as natural science. But considerable variation can be found even within the field of Dutch language and literature. There were no periodicals solely devoted to the study of language. Literature, on the other hand, could take up an entire periodical, i.e. both the production of original work and poetical and historical studies of such work. For example, the Tael- en dichtlievende oefeningen ('lit. Language and poetry-loving exercises', 7 vols., 1775-1790) and the Prijsverhandelingen ('Prize essays', 4 vols. 1782-1790) of the Leiden-based society Kunst wordt door Arbeid Verkreegen 'Art is Acquired by Effort' were almost exclusively devoted to literature (Thobokholt 1983). As mentioned before (Section 4.4), the Kunst wordt door Arbeid Verkreegen society published a normative grammar for internal use in 1770 . In the Tael- en dichtlievende oefeningen, a linguistic essay can only be found in the first volume. The essay deals with the terminology employed for nominal cases (Houtam 1775). Similarly, the Werken ('Works') of the Rotterdam-based society Studium

1. Note that - in the spirit of Johannes $(2011,2015)$ - I am concerned with the earliest stages of discipline formation, i.e. the second half of the eighteenth century and the early nineteenth century, when the first chairs in Dutch studies were established. At that time, there was as yet no influence from historical and comparative linguistics. Many analyses of historical discipline formation in the humanities and in linguistics in particular focus strongly on the revolution established by the rise of historical and comparative linguistics, i.e. on the nineteenth century; see, for example, Karstens (2012), Leerssen (2012), Noordegraaf (2015). 
Scientiarum Genitrix (4 vols., 1789-1796), the Werken of the Amsterdam-based society Wij Streeven naar de Volmaaktheid ('We Strive for Perfection', 1789, 1794) and the various publications of the society Kunstliefde Spaart geen Vlijt ('Love of Art does not Spare Diligence') based in The Hague issued in the 1790s and 1800s were dominated by poetry and poetical essays.

In 1800, the three societies, Kunst wordt door Arbeid Verkreegen, Studium Scientiarum Genitrix and Wij Streeven naar de Volmaaktheid, formed the Bataafsche Maatschappij van Taal- en Dichtkunde ('Batavian Society for the Study of Language and Poetry'), which incorporated Kunstliefde in 1818. The Werken of the Batavian Society comprised various essays on language, all of them written by Siegenbeek (see Section 8.3). In 1806, the society changed its name to Hollandsche Maatschappij van Fraaije Kunsten en Wetenschappen ('Holland Society of Fine Arts and Sciences'). Except for an elaborate discussion of Dutch prosody in the first volume (Kinker 1810), the Werken of this society (4 vols, 1810-1819) mainly focused on poetry and poetical essays.

Texts on language and grammar can mostly be found in the following periodicals. The Tael-en dicht-kundige by-dragen ('Linguistic and poetical contributions') constituted a pioneering publication which came out from 1758 onward. The by and large monthly contributions were collected in two volumes published in 1760 and 1762. Many contributors were students or former students of the universities of Leiden and Utrecht, including Tollius, Tydeman and Kluit, who gathered in networks such as the Leiden-based student society Minima Crescunt and the Utrecht-based student society Dulces Ante Omnia Musae (Kossmann 1966). The Tael- en dicht-kundige by-dragen were succeeded by the Nieuwe bydragen tot opbouw der vaderlandsche letterkunde ('New contributions to the advancement of the letters of the fatherland'), which came out in two volumes in 1763 and 1766. In 1775 and 1780, two volumes were published of Proeve van oudheid-, taal-en dichtkunde ('Example of the study of ancient times, language and poetry'). The Proeve comprised texts created within Dulces Ante Omnia Musae, some of which date from the early 1760s, such as Tydeman's essays on the importance of a national language and a national education system (Tydeman 1775a, 1775a, see Chapter 2).

The student societies Minima Crescunt and Dulces Ante Omnia Musae were also seminal in the foundation of the Maatschappij der Nederlandsche letterkunde ('Society of Dutch language and literature') in 1766 (Kossmann 1966). The Maatschappij published a series of seven voluminous Werken between 1772 and 1788. Its younger 'sister organisation', the Bataafsche Maatschappij van Taal- en Dichtkunde, which had also emerged after the merger of several local networks, published its five Werken between 1804 and 1810. In the 1780s, two periodicals came out that comprised metalinguistic essays, viz. Taal-dicht-en letterkundig kabinet ('lit. Linguistic, poetic and literary cabinet', six volumes, 1781-1784) and 
Taal- dicht en letterkundig magazijn ('lit. Linguistic, poetic and literary magazine', four volumes, 1785-1790). Both were edited by Gerrit Brender à Brandis, who would later become the secretary to the Maatschappij tot Nut van 't Algemeen 'Society for Public Advancement'. Finally, many metalinguistic texts were reviewed in the Vaderlandsche letteroefeningen ('National exercises in the letters'), a general cultural periodical focusing on a wide variety of topics, including Dutch literature and linguistics, published under slightly varying titles from 1761 to 1876.

The metalinguistic commentary found in these periodicals can be organised into four main themes: the position of the study of language in relation to other fields of cultural activity, specifically the production and study of literature (8.2.1), the importance of a national language (8.2.2), linguistics per se (8.2.3), and the historical model of linguistic and cultural change (8.2.4).

\subsubsection{The study of Dutch vis-à-vis other cultural fields}

The first theme concerns the study of language in relation to the production and study of literature. Despite the gradual development from elitist grammar in the first half of the century to so-called civil and national grammar in the second half (Chapter 4), the study of Dutch in these periodicals was often conceptualised in plainly elitist terms with a strong emphasis on literature. Knowledge of the rules of grammar was deemed essential for anyone "who wants to create a good poem in Dutch", as argued in the Tael-en dicht-kundige by-dragen (1760: 137-138), an approach that was continued in the Nieuwe bydragen. In the first volume of the Taal- dicht- en letterkundig kabinet, Brender à Brandis wrote that he started his journal primarily to explain grammatical and poetical rules to jonge Taal-en Dichtminnaars "young lovers of language and poetry" (Taal-dicht-en letterkundig kabinet 1781: I), echoing the elitist discourse of the first decades of the century. The position is repeated in the first essay in the volume (Taal-dicht-en letterkundig kabinet 1781: 1-2). As the elitist approach was part of expensive and learned books, Brender à Brandis (Taal-dicht- en letterkundig kabinet 1781: I-II) also argued that a more simplifying approach was needed, recalling the argument used in civil and national metalinguistic discourse (Chapter 4). The Taal- dicht en letterkundig magazijn continued the approach taken in the Taal-dicht- en letterkundig kabinet.

An aspect of the continued interdependency of language and literature is the identification of exemplary writers who excelled in a poetical as well as in a grammatical respect. These reference points were the literary authors Hooft and Vondel, and the eighteenth-century normative tradition that relied on them (Chapter 4). The linguistic works by Verwer (1707), ten Kate (1723) and Huydecoper (1730) were considered extremely important. Many essays in the periodicals were replete with references to Hooft, Vondel and the eighteenth-century metalinguistic tradition 
(e.g. Tael- en dicht-kundige by-dragen 1760: 77-100, Werken of the Maatschappij 1788: 329-349). The Nieuwe bydragen (1763: 281-352) published an essay on the orthography of Dutch by Adriaan Kluit, which would greatly inspire Siegenbeek, and which was largely written within the historical approach taken by Verwer and ten Kate. In the Proeve van oudheid-, taal-en dichtkunde (1775:208-21), it was argued that the best way to practise linguistics was to follow in the footsteps of ten Kate. In 1783, the Taal- dicht-en letterkundig kabinet (1783: 127) still confirmed that Hooft and Vondel had been the ijsbreekers onzer Nederlandsche spraak icebreakers of our Dutch language'. In 1781, they were referred to as the Grootmeesters 'great masters' of Dutch poetry in the Werken of the Maatschappij (1781: 130). When Huydecoper passed away in 1778, he was called de grootste Bevorderaar onzer Taalkunde 'the greatest promoter of the study of our language' in the Werken $\left(1779:+3^{v}\right)$, along with ten Kate.

The metalinguistic publications reviewed in the Vaderlandsche letteroefeningen in the late 1700s and early 1800s were of two kinds. On the one hand, the journal reviewed texts intended for the liefhebbers 'enthusiasts' of the Dutch language (e.g. Vaderlandsche letteroefeningen 1776: 241, 242; 1782: 326; 1783: 548, 549; 1784: 304; 1800: 343$)$. These texts mostly included fairly complicated grammatical treatises, conceptualised within the elitist framework of linguistics expertise as a precursory demand for writers interested in literature and rhetoric. On the other hand, the Vaderlandsche letteroefeningen (e.g. 1777: 44-45; 1778: 540; 1800: 344; 1805: 462, 516) also published reviews of schoolbooks, thus confirming the development of a national concern with grammatical expertise as a prerequisite for the entire population.

\subsubsection{The national language}

Another important theme in the periodicals was the nationalisation of language, particularly the need for a uniform spelling. Whereas it was sometimes claimed that the actual orthographic form of the national language, i.e. the specific choice of graphemes, was not important as long as it was uniformly used throughout the nation, this claim functioned as a rhetorical prelude to a detailed discussion of preferred and dispreferred variants (Tael-en dicht-kundige by-dragen 1760: 205-233; Proeve van oudheid-, taal-en dichtkunde 1775: 79-102). In line with the popularity of Verwer, ten Kate and Huydecoper, the process of selection and variant reduction was usually dominated by a historicising discourse, that is, historical, often medieval forms and etymological arguments were used to justify specific choices. This was also Kluit's approach in his essay on spelling (Nieuwe bydragen 1763: 281-352), in which he argued that Middle Dutch represented an analogical stage of the language to which he thus wanted to turn for guidance, recalling Verwer's and ten Kate's position (van de Bilt 2009: 197-198). 
As mentioned above (see also Section 2.3), the Proeve van oudheid-, taal-en dichtkunde (1775: 1-20) comprised Tydeman's essays of the early 1760s in which he argued for a uniformed national language, which the government should implement in education. This national language was obviously not the spoken home language of large parts of the population, but the normalised written language promoted in literary and metalinguistic sources. In other words, the national language was a learnable variety that members of the Dutch nation should acquire through explicit education (cf. Section 6.5). They should not consider "the language defects that they sucked up from their wet nurses as if they were milk" to be beautiful (Taal-dicht-en letterkundig kabinet 1781: 138). Similarly, though within the elitist framework, young poets should learn their moederspraak 'mother tongue' (Taaldicht- en letterkundig kabinet 1783: 250). By implication, the regional variety that they had grown up with, was not their mother tongue, and may not even have been a language at all (Section 6.5).

The combination of the persisting elitist approach and the historical interest had consequences for the study of the national language as well. To learn zuiver Neêrduits 'pure Dutch' implied an intense study of the oldest Dutch texts, i.e. of the Middle Dutch works of Maerlant, Stoke and others (Taal-dicht en letterkundig magazijn 1788: 118). Those who wanted to understand and write their mother tongue well were forced to read and contemplate its oldest sources, so that they would learn what pure and good Dutch consisted of, and to be able to enrich their mother tongue by exploring its own historical sources (Taal-dicht en letterkundig magazijn 1788: 119).

Thus, the national language was in need of codification, but was at the same time a historical object in that decisions in the selection process often depended on historical arguments. Given the controversial position of loans, particularly from Romance languages such as French and Latin, in the debate about a national dictionary (Chapter 7), it is not surprising that also here verfransing 'Frenchification' was seen as a real risk that could lead to the degeneration of "our old pure language" (Proeve van oudheid-, taal-en dichtkunde 1780: 139). Loan translations were to be avoided, unless one wanted to advance "the corruption and decay of our Dutch language" (Vaderlandsche letteroefeningen 1810: 215). The gradual corruption of the Dutch language as a result of the ongoing contact with Romance languages should be reversed by the national government through the adoption and the consistent use in its publications of a pure form of Dutch (Taal-dicht en letterkundig magazijn 1788: 143-157).

Contact-induced changes were unpopular. On the contrary, older stages of the language and historical argumentation played an important role in the selection process, and diachronic variation was thus accepted as an inherent characteristic of the national language. But this was the only generally accepted type of variation. Regional variation was only marginally addressed. An illustrative case in 
point is a discussion of the sixteenth-century Psalm translation by Datheen (Taelen dicht-kundige by-dragen 1760: 65-100). The translation had been criticised for Datheen's use of bipartite negation, which was a common form well into the seventeenth century (Rutten \& van der Wal 2014: 364-365). The Tael- en dicht-kundige by-dragen (1760: 69-71) defended bipartite negation with exactly this argument: it was a common form in the sixteenth century, and even in the seventeenth century, for example in the official Bible translation of 1637. The historical evidence served to prove that bipartite negation was part of the "nature of our language" (Tael- en dicht-kundige by-dragen 1760: 69). Significantly, any references to regional variaties in which bipartite negation was still common in the second half of the eighteenth century are absent (cf. Rutten et al. 2012; Vosters \& Vandenbussche 2012). What is extremely remarkable, therefore, is the tolerant position towards a handful of regional variants taken in the Taal- dicht- en letterkundig kabinet (1781: 154-158). This tolerance is, however, limited to the spoken language, recalling ten Kate's suggestion to apply the rhetorical distinction between lower and higher registers to grammatical variation (Section 4.5).

\subsubsection{Linguistics}

The periodicals also comprised a range of often detailed linguistic studies of specific linguistic features. Many of these studies entailed etymological exercises in the tradition of the so-called Schola Hemsterhusiana (Noordegraaf 1996), with a focus on ancient root words and sounds signaling original meanings (e.g. Tael- en dicht-kundige by-dragen 1762: 285-296). In fact, the Nieuwe bydragen $(1763,1766)$ and the Proeve van oudheid-, taal- en dichtkunde $(1775,1780)$ were dominated by etymological studies of singular words and groups of words, often replete with references to ten Kate.

In addition, the periodicals published essays in which lexical and grammatical variants were compared, usually with the goal of reducing the number of acceptable variants. Topics included functionally and/or formally similar forms such as als 'as' and dan 'than' (Proeve van oudheid-, taal- en dichtkunde 1775: 145-146), zelf, zelve 'himself, herself, itself', zelfs 'even', dezelve 'this one' and dezelfde 'the same' (Taaldicht en letterkundig magazijn 1785: 65-70), and homonyms and near-homonymic expressions such as komen doen 'lit. come do' and komen te doen 'lit. come to do' (Proeve van oudheid-, taal-en dichtkunde 1775: 147-149) and nog 'still' and noch 'nor' (Proeve van oudheid-, taal- en dichtkunde 1780: 151-162, see also Taal- dicht- en letterkundig kabinet 1783: 127-172, Taal- dicht en letterkundig magazijn 1787: 181-183).

As stated above, the choice between variants was often facilitated by the historicising approach. In other words, in many of the grammatical essays discussing 
competing variants, etymological arguments and historical evidence figured prominently, for example in discussions about the diminutive suffix (-jen or -je, Taaldicht-en letterkundig kabinet 1783: 179-185), about verleeden vs voorleeden 'former, past' (Taal-dicht en letterkundig magazijn 1785: 71-80), and also in the well-known debate about the existence in Dutch of the so-called ablativus absolutus in the first volume of the Werken of the Maatschappij (1772, cf. Komen 1994), and in Alewijn's contributions to, for example, the seventh volume (Werken 1788: 301349), in which he was engaged in detailed discussions of the acceptability of specific variants, relying on historical evidence and the analyses of ten Kate, Verwer, Huydecoper and others.

\subsubsection{The historical model of linguistic and cultural change}

As discussed before (see above and Section 5.3), the Golden Age of the seventeenth century constituted the prime normative point of reference, from the late seventeenth century onwards and well into the nineteenth century. The Golden Age, however, represented a period of renewed purity of the Dutch language and the cultural products written in this language. The historical model of linguistic and cultural change propagated in the periodicals assumed a period of regularity in the Middle Ages, which was subject to degeneration, particularly in the fifteenth and sixteenth centuries due to foreign rule, after which the Golden Ages reset the Dutch language, which regained the purity and regularity of medieval times. The proposed development, both linguistically and culturally, from an original state of purity to increasing degeneration was prominent throughout the Tael- en dicht-kundige by-dragen, the Nieuwe bydragen and the Werken van de Maetschappy. After the Golden Age had restored the Dutch language and literature, a second phase of recovery was necessary in the second half of the eighteenth century due to ongoing foreign, i.e. French influence in the Low Countries. This model of linguistics and, more generally, cultural change confirmed the entirely historical view of the language, and the need to recover the national language from historical sources.

\subsubsection{Conclusions}

The studies of language in the periodicals published in the second half of the eighteenth century were mostly engaged in etymology and in a selection process in which historical arguments were important. These linguistic studies were part of publications that also contained poetical studies, historical studies and poetry. Thus, the study of language was integrated into a wider field of knowledge, and was also, to a large extent, propedeutical with respect to literature, recalling the elitist approach of the first half of the century. 
The significance of historical argumentation and etymology indicate the continuing influence of Verwer, ten Kate and Huydecoper. However, the historicisation of the language did not signal a general interest in the description and explanation of language change. On the contrary, historical stages of the language, most prominently the Middle Dutch from before the Burgundian period, and the seventeenth-century Dutch of the Golden Age, were historical mirrors displaying the high level of purity and regularity principally achievable in Dutch. In addition to the elitist approach and the increasingly historical perspective of the language, arguments were developed in favour of a national language, in line with the changes in the tradition of normative grammar (Chapter 4).

Finally, the periodicals were characterised by the uncontested identification of the history of the literary language and the history of the language itself. Variation in the written code remained mostly unacceptable. Where it was acknowledged, it became subject to variant reduction. In the case of lexical variation in particular, a discourse against Frenchification was adopted. Variation in the spoken code was hardly acknowledged, with one notable exception in the Taal-dicht-en letterkundig kabinet.

\subsection{Matthijs Siegenbeek and the Dutch language}

Matthijs Siegenbeek was the author of the first official spelling of Dutch (1804a), and he has long been considered the first professor of Dutch. For this section, I have chosen to focus on Siegenbeek as the one of the most important cultural agents during the first half of the nineteenth century, particularly in the field of Dutch studies. I will mainly focus on Siegenbeek's linguistic publications, as his work on literary history and rhetoric has attracted quite some attention over the years.

Siegenbeek was born in Amsterdam on 23 June 1774 in a Mennonite family. ${ }^{2}$ After having finished Latin school, he attended the theological seminary of the Mennonite community in Amsterdam, where he was made ordinand in 1795 . He subsequently moved to Dokkum in the province of Friesland, where he became the minister of the local Mennonite community. Already in 1796, however, he was contacted by Laurens van Santen, a member of the town council of Leiden and a curator of the local university, inquiring whether Siegenbeek would be interested in the

2. This paragraph is based on the entries on Siegenbeek in volume 17 (1874) of the Biographisch woordenboek der Nederlanden by A. J. van der Aa, and in volume 5 (1921) of the Nieuw Nederlandsch Biografisch Woordenboek (NNBW), edited by P. J. Molhuysen and P. J. Blok, as well as the biography by S. Muller, published in the Handelingen der jaarlijksche algemeene vergadering van de Maatschappij der Nederlandsche Letterkunde te Leiden, gehouden den 21 Junij 1855 (s.l., s.d.). 
newly established chair of Dutch rhetoric at Leiden University. Van Santen had had this plan at least since the autumn of 1795, when he had made a similar proposal in the Board of Curators (Molhuysen 1924: 16; Wiskerke 1995: 201). Siegenbeek accepted the offer and on 23 September 1797, he delivered his inaugural lecture on Openbaar onderwijs in de Nederduitsche welsprekendheid ('Public education in Dutch rhetoric'), testifying to the fact that he was first and foremost appointed to improve the rhetorical competence of the students, particularly those of theology and law. In 1799, his extraordinary chair was changed into a regular chair, and the description of its theme was widened to Dutch language and literature, which included rhetoric. He would remain in office until 1844, when he was 70 years old, but continued to teach sporadically until 1847, when he celebrated his fiftieth anniversary as a university professor. He also served twice as Rector Magnificus of Leiden University (1809-1810 and 1823-1824).

Siegenbeek would soon occupy a central position in many cultural networks of the Netherlands. From 1803 to 1822, he was the secretary of the Maatschappij der Nederlandsche Letterkunde, and from 1822 to 1847, he was its chair. He published numerous books, essays, editions and lectures, some of which will be discussed below, and was an important contributor to cultural magazines such as the Werken der Bataafsche Maatschappij van Taal-en Dichtkunde ('Proceedings of the Batavian Society for Linguistics and Poetics', 1804-1810), Museum (1812-1817) and Mnemosyne (1815-1828). A quick glance at Siegenbeek's correspondence as kept in Dutch archives and libraries reveals that he occupied a central place in various partly overlapping social and cultural networks. ${ }^{3}$

Siegenbeek's activities as a historian of Dutch literature and as a teacher of rhetoric have been studied more extensively than his linguistic works. His main task as the newly appointed professor of Dutch was to teach Dutch rhetoric to university students, particularly, though not exclusively, to the next generation of ministers and lawyers in the faculties of theology and law. Not uncommon for the eighteenth and nineteenth centuries, and in keeping with the aforementioned unity of the study of language and literature, the concept of welsprekendheid 'rhetoric' that Siegenbeek adopted encompassed the study of language and literature (Section 8.2; cf. Vis s.d.: 43-44). Siegenbeek, in need of study materials, used both classical sources such as Longinus and Quintilian, as well as the works of the well-known Scottish professor of rhetoric at Edinburgh, Hugh Blair, whose focus on style as a crucial part of his so-called belletristic approach to rhetoric was by and

3. The Leiden University Library, for example, holds letters written between Siegenbeek and well-known cultural, literary, academic and political agents such as Jeronimo de Bosch, Arie de Jager, Cornelis Felix van Maanen, Johan Hendrik van der Palm, Laurens van Santen, Meinard and Hendrik Willem Tydeman, Jan Frans Willems, to name but a few. 
large adopted by Siegenbeek (Sjoer 1996: 61-63, 169-180). The study of language and literature was part of Siegenbeek's style-oriented approach to rhetoric. In lecture notes made by students kept in the University Library in Leiden, Siegenbeek always stressed the importance of a preceding analysis of the grammar of Dutch, as well as of the Dutch literary and oratorical exempla that are needed to illustrate the rhetorical principles. He considered knowledge of the grammar of Dutch to be required in order to reach a high level of stylistic refinement, and examples of famous authors who had reached a high stylistic level would help students in their development. This means that Siegenbeek's rhetorical lessons began with an overview of the grammar of Dutch (Sjoer 1996: 169-170). Furthermore, he taught the history of Dutch literature focusing mainly on seventeenth-century examples representing good style and good taste (Sjoer 1996: 175; Vis s.d.: 43-46). Based on his courses at Leiden University, Siegenbeek published a history of Dutch literature in 1826. His rhetorical lessons have survived in the aforementioned lecture notes. ${ }^{4}$

In another set of lecture notes, Siegenbeek said that his lessons deserve "the name of Lessons in Dutch rhetoric in as far as they are specifically organised to train the Dutchman in the rhetoric of his mother tongue", 5 a phrase which also occurs in other lecture notes (Sjoer 1996: 170). With this preliminary remark, Siegenbeek showed that he was well aware of the fact that the sheer existence of his dedicated chair should be interpreted in the ideological light of the Batavian revolution, which means that the chair was a cultural tool in the ideological construction of a united and homogeneous Dutch nation (Wiskerke 1995: 201-203). After having stated the general goal of his lecture, Siegenbeek explained the interrelatedness of rhetoric with the study of language and literature as follows:

behoort daartoe myn 's inzien 's, in de eerste plaats eene Ontvouwinge van de Eigenschap, kracht en uitgebreidheid onzer Moeder Sprake. Immers is eene naauwkeurige Taalkennis buiten tegenspraak de grondslag der Welsprekenheid. - dit is met betrekking tot onze Taal des te noodzakelyker, omdat zy door't gebruik alleen, zelden door het voorschrift eener gezuiverde Spraakkunst geleert wordende, door veelen ten uitersten onachtzaam gesproken \& geschreven wordt en de verwaarlozing van de voortbrengselen onzer oudste \& Achtbaarste Schryveren, de meeste met hare volle Kracht \& uitgebreidheid onbekend doet blyven

(Academische voorlezingen s.d.; 5-6)

4. The Leiden University Library holds, for example, a manuscript called Lessen over de Nederduitsche welsprekendheid ('Lessons in Dutch rhetoric'), comprising 133 pages on grammar and 277 pages on rhetoric (signature LTK 137), as well as a manuscript called Lessen over den Nederduitschen stijl ('Lessons in Dutch style'), comprising 292 pages (LTK 136). Cf. Sjoer (1996: 169-170).

5. Academische voorlezingen (s.d.: 2): "deze lessen [...] den naam van Lessen over de Nederduitsche Welsprekenheid geven, voor zo verre zy byzonderlyk ingericht zyn om den Nederlander tot Welsprekenheid in zyne Moeder Taal opteleiden." 
belongs to this [i.e. to rhetoric], in my view, in the first place an explanation of the nature, firmness and extensiveness of our mother tongue. After all, accurate linguistic knowledge is without any doubt the foundation of rhetoric. This is all the more necessary with respect to our language, because it is extremely carelessly spoken and written by many, being learnt through usage only, and hardly through the prescription of a purified grammar, and because the neglect of the products of our oldest and most honourable writers renders its full firmness and extensiveness unknown to most people.

Siegenbeek thus signalled two problems that had to be resolved before a full introduction to Dutch rhetoric would be possible: lack of knowledge of the grammar of Dutch, and lack of knowledge of the literary tradition. He immediately added that an introduction to the grammar of Dutch and an anthology of the best writers would therefore be part of his course on rhetoric (Academische Voorlezingen s.d.: 6.)

These concerns with the history of Dutch literature have made Siegenbeek an important literary historian. Usually, his involvement in literary history is explained with reference to cultural nationalism. Wiskerke (1995: 203), for example, comments that for Siegenbeek, nationalism was the motive for exercising his duties as a professor of Dutch. The national literary history, as developed by Siegenbeek, also encompassed socio-political history and linguistic history, and resulted in an approved story of the rise, greatness and fall of the national culture (Wiskerke 1995: 199, 207-208). As such, Siegenbeek contributed strongly to the Dutch myth of the Golden Age (Chapter 5). He considered the literature of the seventeenth-century to be the point de la perfection of Dutch literary history, in which the works of the authors P. C. Hooft (1581-1647) and Joost van den Vondel (1587-1679) played a crucial role (Wiskerke 1995: 199, 208, 215-216).

In his earlier overviews of the history of Dutch literature, made in the years 1800-1802, Siegenbeek located the beginning of the Golden Age in the early seventeenth century, with Hooft and Vondel, and let it continue until his own time (Wiskerke 1995: 219-220). In other words, he talked about the rise and flourishing of Dutch literature, but not about its decay or fall. A few years later, in 1806, his ideas changed to what would become the traditional nineteenth-century view, according to which the second half of the seventeenth century and the eighteenth century were marked by decay. This decay was not caused by the sudden absence of knowledge of genre conventions and normalized language in the period 1650-1800, which persisted, but by the lack of exceptional talents such as Hooft and Vondel instead (Wiskerke 1995: 260-264). Jensen (2012) offers a political explanation of why authors such as Siegenbeek increasingly viewed the early seventeenth century as the Golden Age of Dutch literature and the subsequent period as one of decay. The year 1806 marks the end of Dutch independence, as the Netherlands were incorporated into the French state, which gave rise to an increase of anti-French sentiments, and 
which fuelled the search for a national cultural heritage of unsurpassable quality. Siegenbeek's changing view of literary history ties in neatly with his ideas about the linguistic history of Dutch.

\subsubsection{Siegenbeek's linguistic heritage}

In addition to his literary and rhetorical studies, Siegenbeek also worked on Dutch linguistics, his prime achievement arguably being the 1804 spelling regulation. Siegenbeek's spelling saw several reprints, for example a fourth one in 1827, and moreover an abridged version ten dienste der scholen 'for the benefit of the schools' came out in 1805 and 1822. At the request of the Maatschappij tot Nut van 't Algemeen, Siegenbeek wrote a Syntaxis and a Grammatica, published anonymously in 1810 and 1814 (Noordegraaf 1985: 227-230). For both the syntax and the grammar, Siegenbeek relied on Weiland's grammar of 1805 (Noordegraaf 1985: 232-252).

The official spelling was founded on a limited set of principles, the most important one of which was to write in accordance with the pronunciation - to "write as you speak" (Siegenbeek 1804a: 13). Intuitive as this may sound, Siegenbeek was probably well aware of the many regionally and socially conditioned phonetic differences. He rephrased the principle in terms of following the most pure and most polite pronunciation, where polite refers to the language characteristic of the most polite people (Siegenbeek 1804a: 18-19), and, as Daan (1989: 199) comments, of the region of Holland. Purity refers to the need to give each letter, as Siegenbeek says, the sound that characterises it, as well as to the prerequisite to pronounce all the letters that belong to a word fully and in an unmixed way (1804a: 18).

The latter definition along with the assumed but probably non-existent familiarity with the social dialect of the Holland elite among the average schoolteacher, who was supposed to teach the national language and its spelling, sparked off many spelling pronunciations (see also Chapter 10). These were immediately commented upon by language experts (Daan 1989: 199-200). One of these was Siegenbeek, who stumbled upon them in his profession as a school inspector, and subsequently published an essay on "some current corruptions of the pronunciation of the mother tongue" in an educational journal (Siegenbeek 1836). While it remains uncertain to what extent all the features he discussed should be considered spelling pronunciations, it is clear that some of them were, as they involved the pronunciation of silent graphemes, or 'letters', which were only written for etymological reasons. These include the realisation of menschen 'people' as [mensxən] instead of [mensən], where $<\mathrm{ch}>$ should remain silent, and the realisation of the final vowel in duidelijk 'clear' and sterfelijk 'mortal' as $[\varepsilon \mathrm{I}]$ instead of schwa. Siegenbeek wrote this short 
essay for schoolteachers who were unfamiliar with the targeted pronunciation and used spelling pronunciations instead, and ultimately, as he declared in the final sentence (1836: 53), to preserve the purity and the euphony of de Vaderlandsche taal 'the language of the fatherland'.

In the early nineteenth century, Siegenbeek also wrote three extensive essays on language. In 1804, the first volume of the Werken of the Batavian Society (pp. 1-108) published an essay discussing the question in hoe ver behoort de spelling der Nederduitsche taal geregeld te worden naar de welluidendheid en gemakkelijkheid der uitspraak 'to what extent should the spelling of the Dutch language be regulated according to the euphony and the ease of pronunciation'. Siegenbeek's Betoog van den rijkdom en de voortreffelijkheid der Nederduitsche taal, en eene opgave der middelen om de toenemende verbastering van dezelve tegen te gaan ('Essay on the affluence and the excellence of the Dutch language, and statement of the means to counter its increasing corruption') came out in volume five, published in 1810 (pp. 1-273). The periodical Museum published Siegenbeek's essay on het verband tusschen de taal en het volkskarakter der Nederlanderen 'the connection between the language and the national character of the Dutch' (1814b: 89-125).

In later years, fewer linguistic publications appeared. When Kinker published a critical discussion of the 1826 Nederlandsche spraakleer ('Dutch grammar') by Bilderdijk, he added a lengthy letter Siegenbeek had written to him on the same matter (Kinker 1829: 341-370). In 1847, Siegenbeek published a Lijst van woorden en uitdrukkingen met het Nederlandsch taaleigen strijdende ('List of words and expressions adverse to the Dutch idiom'). Finally, some of the lecture notes kept in manuscript form also comprise extensive parts on linguistics, for example the Aantekeningen van $M$. Siegenbeek and the Academische voorlezingen are largely devoted to an overview of Dutch normative grammar (Noordegraaf 1985: 283-242).

Due to the inherent interrelatedness of language, literature and rhetoric, Siegenbeek often also commented on linguistic issues in publications on rhetoric and literary history, for example in his essay on the seventeenth-century poet Vondel, published in the second volume of the Werken of the Batavian Society (1807: 35-108), and also in his concise history of Dutch literature (Siegenbeek 1826), and his two inaugural lectures of the late 1790s (Siegenbeek 1800).

In what follows, I will discuss three dominant and recurrent themes in Siegenbeek's linguistic publications, viz. the seventeenth century or Golden Age as a normative point of reference (8.3.2), the status of Dutch in relation to French and German (8.3.3), and the Dutch language as a symbol of the Dutch nation (8.3.4). 


\subsubsection{The Myth of the Golden Age}

Siegenbeek was an ardent supporter of the Myth of the Golden Age (see Section 5.3). In a thoughtful overview of the concept of the Golden Age as it functions in a variety of nineteenth-century histories of Dutch literature meant for schools and/ or home study, Johannes (2002) discusses the obvious problems the authors of these handbooks encountered. One example is the supposedly close connection between the Golden Age and Protestantism, and the prevailing image of the seventeenth century as the period of the rise of the Dutch nation as a Protestant nation. In reality, quite a few of the famous poets were Catholics, including Vondel. Another example is the general depreciation of the Early Modern chambers of rhetoric and the view of their members as Frenchified poetasters, while many seventeenth-century writers such as Hooft and Vondel were in fact members of such chambers of rhetoric.

In the case of language, the problems were at least as pervasive. As Siegenbeek acknowledged in the introduction to his orthography, the spelling differences between the most admired authors of the Golden Age, Hooft and Vondel, were great in many respects; in the absence of general regulations, there were almost as many spelling systems as there were authors, and many writers presented themselves as language experts without having any authority to do so (1804a: 2-6). The obvious linguistic differences between the Golden Age and the early nineteenth century were pointed out by Siegenbeek on various occasions, for example in his second inaugural lecture about Hooft as a poet and historian, as well as in the preface to an edition of Hooft's main historical works (Siegenbeek 1800: 75; Siegenbeek et al. 1820: III). This comparison did not always work out to Hooft's advantage, whose language was sometimes uncivilised, unnatural and lacking euphony (1800: 75). This did not prevent Siegenbeek from setting up the Golden Age scheme, which also encompassed language. In his essay on the affluence and the excellence of the Dutch language, he hailed Hooft as an author beyond compare for both the contents and the language of his works (1810b: 261). In an essay on the literary merits of Vondel, he claimed that Hooft and Vondel were the first to expose den rijkdom en de schoonheid onzer moedertaal 'the richness and the beauty of our mother tongue' (1807: 97). Similar claims are made in Siegenbeek's history of Dutch literature (1826: 346).

The inherent tension outlined above was easily solved, as Siegenbeek provided hardly any concrete linguistic examples taken from Hooft and Vondel showing their linguistic perfection vis-à-vis earlier or more recent authors. He described their linguistic excellence in abstract terms, claiming that their works stood out for their richness and beauty. When Siegenbeek did engage with more concrete 
linguistic matters, as in his spelling proposal and in his lecture notes on the grammar of Dutch, he actually followed the eighteenth-century tradition of normative grammar (e.g. Noordegraaf 1985: 252; van der Wal \& van Bree 2008: 241). As Siegenbeek must have known, eighteenth-century metalinguistic discourse was heavily influenced by the written language of the seventeenth century, that is, it was a strongly Vondelianist discourse. This means that there was an indirect link from Siegenbeek back to the seventeenth century, to the Golden Age. Nevertheless, he readily acknowledged that the eighteenth century was far more advanced than the seventeenth century in terms of linguistic normalisation, while even at his time, orthographic uniformity was still lacking, which was, of course, one of the reasons behind his spelling proposal (Siegenbeek 1804a: 1-2; 1826: 230). In spite of the greater uniformity in spelling and grammar characteristic of the eighteenth century, the general claim that the Golden Age constituted the period to which nineteenth-century language users should turn remained unproblematic as it fed on the intrinsic and inseparable relationship of literature and linguistics. Vondel and Hooft were the best language users, simply because they were the best authors. This linguistic perfection of Vondel and Hooft was primarily a discursive construction relevant in the context of early nineteenth-century nationalism, and we can assume Siegenbeek was aware of this.

On many occasions, Siegenbeek referred to the revival of Dutch language and literature in the first half of the seventeenth century, identifying this period as the Golden Age and limiting himself to the abstract claim that the language of Vondel and Hooft was the best language. In one respect, however, he made the Golden Age scheme linguistically slightly more concrete. The Golden Age of Vondel and Hooft brought an end to the widespread use of loans, particularly from French. Without discussing which loans specifically were replaced by endogenous forms, Siegenbeek (1807: 96) described the Golden Age as one of lexical purism, and Hooft and Vondel were forerunners in the purification of Dutch. Schematically, the impure period of the sixteenth century was succeeded by the Golden Age, which then gave way to another impure period from the second half of the seventeenth century to the late eighteenth century. The lack of purity, both before and after the Golden Age, was closely tied to the use of French loans, and the eighteenth century in particular has often been viewed as a time of vehement Frenchification (see 5.2). Here, the myth of the Golden Age connects with the position of Dutch as a neighbour of French and German. 


\subsubsection{Dutch in contact with French and German}

The position of loans and loan translations, particularly from Romance languages such as French, was insecure in the eighteenth and nineteenth centuries. They were strongly criticised and purist ideologies prevailed (Chapter 7). Siegenbeek was no exception to this approach. Johannes (2002) describes how nineteenth-century historians of Dutch literature built up the image of the Golden Age, particularly the first half of the seventeenth century, as caught between two periods of verfransing 'Frenchification' (cf. above and 5.3). Traditionally, the eighteenth century has been considered the period in which the Low Countries were heavily influenced by France, politically, socially, culturally and linguistically. The idea of the Frenchified eighteenth century has been criticised in more recent times, at least from Frijhoff's (1989) seminal study onwards. The supposedly increasing Frenchification from the second half of the seventeenth century onwards created a convenient terminus ad quem for the Golden Age. In their search for a terminus a quo, literary historians proposed the second half of the sixteenth century, when a purified form of Dutch literature replaced the preceding stage characterised by Burgundian corruption and the heavily Frenchified chambers of rhetoric (Johannes 2002: 32). In the fourteenth and fifteenth centuries, large parts of the Low Countries came under Burgundian rule, and subsequently under Habsburg/Spanish rule. These political circumstances would have brought about the Frenchification of Dutch language and literature, most strongly visible in the widespread use of loans, as in the poems and plays created within the various chambers of rhetoric. The Golden Age of purified Dutch from the second half of the sixteenth century to c. 1650 was more or less coterminous with the Dutch Revolt or Eighty Years' War (1568-1648), and with the political and economic success of the Dutch Republic.

Anti-French sentiments can be found throughout Siegenbeek's work. The linguistic publication that delved deepest into the matter was the 'Essay on the richness and the excellence of the Dutch language, and statement of the means to counter its increasing corruption' (Siegenbeek 1810b). In it, Siegenbeek (1810b: 6) lamented the general neglect of Dutch literature and the Dutch language among the Dutch people of the eighteenth and early nineteenth century, particularly among the upper ranks, who appropriated French manners and cultural products, and who preferred the French language, considering Dutch as eene plompe en boersche spraak 'a rude and lumpish language'. In the first chapter, he demonstrated the affluence of Dutch by discussing its extensive lexicon, well-suited to communicate all the small nuances of human thought, and all the stylistic shades one could possibly need, which he illustrated with examples mainly taken from seventeenth-century authors (Siegenbeek 1810b: 13-119). He also argued for the morphological uniqueness of Dutch, which he considered to comprise a remarkable number of monosyllabic 
words, testifying to its old age, and an equally remarkable capacity to create compounds of these monosyllables. Here, Siegenbeek explicitly tied in with Grotius' views on the architecture of the Dutch lexicon, which were in turn dependent on Stevin's views. ${ }^{6}$

In the second chapter, devoted to the excellence of Dutch, Siegenbeek (1810b: 119-223) again discussed the old age of the language, connecting this also with a notion of purity. As an ancient and pure language, Dutch had kept its original lexicon comprising monosyllables as well as compounds and derivations with the accent on the original root, i.e. on the semantically most important morpheme. As such, Dutch differed sharply from French, the lexicon of which mainly consisted of loans from Latin and Greek. Here, Siegenbeek again relied on Grotius, but also on early eighteenth-century linguists such as ten Kate and Huydecoper. Siegenbeek thus created an image of the Dutch language as one that stood out for its lexical and morphological properties, which he immediately linked to its old age and purity, and which demonstrated the superiority of the language when compared to French.

Less prominent in Siegenbeek's works are references to German, despite the fact that his grammatical works were influenced by Adelung, particularly the Umständliches Lehrgebäude der deutschen Sprache of 1782 (Noordegraaf 1985: 235237). In Siegenbeek's 1810 essay, the relationship between Dutch and French dominated, although German was not entirely absent. In the second chapter on the excellence of Dutch, Siegenbeek (1810b: 119-123) praised the euphony of Dutch consonants when compared to their German counterparts. In the following pairs, the Dutch voiced stops and fricatives were contrasted with the German unvoiced alternatives, and Siegenbeek considered voicing to be 'softer', and therefore better: vuil-faul 'dirty, (Gm.) rotten, lazy', vroom-fromm 'pious', moeder-Mutter 'mother', dal-Thal 'valley'. Siegenbeek (1810b: 140) also criticised the 'harsh and rude' affricate $p f$ - as in German $p$ flicht 'duty'. Siegenbeek's more recent 'List of words and expressions adverse to the Dutch idiom' (1847) predominantly comprised and criticised German loans. The apparent change of orientation from anti-French to anti-German in Siegenbeek's linguistic writings may signal wider changes in international cultural contacts and their discursive representation.

Siegenbeek's criticism of French loans and his conceptualisation of particularly the long eighteenth century as a period of Frenchification was entirely traditional, and fitted in well with contemporary and more recent discourses on French dominance and Francophilia in this period (Vogl 2015; Rutten, Vosters \& van

6. Hugo Grotius' manuscript Parallelon rerum publicarum of c. 1602 was published in 1801-1803 by Johan Meermann. Simon Stévin's text on the worthiness of the Dutch language ('Uytspraek van de Weerdigheyt der Duytsche Tael') was published in his 1568 book De Beghinselen der Weeghconst. See van der Wal (1997). 
der Wal 2015). A particular characteristic of Siegenbeek, who was a professor of Dutch and a school inspector, was perhaps his focus on a remedy and even more so, his insistence that the supposed Frenchification could be countered through mother-tongue education. After having established "the general neglect of and contempt for the language and literature of the fatherland", which was supposed to be the result of the decreasing love of the fatherland, Siegenbeek argued that to cure this "evil", a new kind of mother-tongue education would be necessary in order to teach "the polite Dutchman" knowledge of the Dutch language as well as to excite "the spirit of love of the fatherland". This new kind of mother-tongue education should encompass schoolbooks with historical and literary texts, particularly from the seventeenth century, as well as anthologies of poets such as Vondel and Hooft (Siegenbeek 1810b: 259-264). He also called for a new purist dictionary (Siegenbeek 1810b: 266-267).

The educational solution offered by Siegenbeek in his essay on "the means to counter the increasing corruption" of Dutch linked up with his first inaugural lecture "on public education in Dutch rhetoric" (Siegenbeek 1800: 1-52). This lecture had a strong apologetic undertone, reflecting Siegenbeek's position as the first professor with a chair solely devoted to the study of Dutch. Noordegraaf (1985: 221; cf. Vis s.d.: 44) called it an oratio pro domo, as Siegenbeek took half of his lecture to explain that Dutch rhetoric was equally well possible as Greek and Latin rhetoric, illustrating this by identifying a respectable Dutch tradition including Vondel and Hooft.

Siegenbeek (1800: 52) ended his lecture by paying special attention to three societal domains that he apparently considered crucial in the context of his chair, viz. the University of Leiden, the arts and sciences generally, and finally, the fatherland. The whole line of reasoning of the lecture was framed in a nationalistic discourse, indicating not only the necessity of teaching Dutch rhetoric - which encompassed both literature and linguistics (cf. 8.1 and 8.2.1) - but also the advantages that an advanced level of rhetoric would have in the legal and religious domains, and above all in parliament (Noordegraaf 1985: 221). Siegenbeek was well aware of the symbolic relevance of his academic position for the Dutch nation as an ethnic and political body.

7. Siegenbeek (1810b: 243, 250): "die algemeene verwaarloozing en geringschatting der vaderlandsche letterkunde", "het kwaad”, "de beschaafde Nederlander", "ter vroegtijdige opwekking van dien geest van vaderlandsliefde". 


\subsubsection{The language of the nation}

The conceptual fusion of language and nation (Section 2.3) is one of the main themes of the present study. Here, too, Siegenbeek may count as an exemplary case, particularly in his 1814 essay "on the connection between the language and the national character of the Dutch". Siegenbeek (1814b: 89-90) formulated three principles from which he developed his argument, viz. that man is primarily and uniquely defined by his language, that his language is a mirror of his soul, and that his language is also a mirror of the cognitive and moral character of the nation he is part of. From the third, 'Humboldtian' assumption, it follows that the basic characteristics of a nation must be strongly and significantly present in its language. ${ }^{8}$ With this 'Humboldtian' approach to the interrelationship of language and nation, Siegenbeek took up a theme well-known across eighteenth- and nineteenth-century Europe, including Germany and the Low Countries (Noordegraaf 1999). The remainder of Siegenbeek's essay was devoted to an inventory of characteristics of the Dutch people, and the way in which these were represented in the Dutch language.

The first characteristic of the true and pure Dutchman was his calmness and sensibility - a myth that lives on until the present day - which was in contrast with fire and liveliness, but also with the frivolity and fickleness of the southern peoples (Siegenbeek 1814b: 96). Here, Siegenbeek evoked an opposition of Germanic and Romance that he would return to several times. Linguistically, the moderate character of the Dutch was reflected in the phonology of the language, which had neither too many vowels nor too many consonants. Languages with many vowels may sound pleasant and harmonious, but were also a bit too "melting, tender, and, if I may say so, effeminate". ${ }^{9}$ Languages that combined too many consonants in difficult clusters "hurt the ear with an unpleasant coarseness". ${ }^{10}$ Dutch, then, was located between these stereotypical images of Romance and Germanic languages. In 1779, in a poetical essay, Cornelis van Engelen (1779: 197) had contrasted the vowelly Italian with the much less vowelly German, claiming

8. Siegenbeek (1814b: 93): "Het kan derhalve niet anders zijn, of ook de hoofdtrekken van het karakter van eener natie moeten in de taal, van welke zij zich, als de haar eigene en door haar zelf gevormde, bedient, krachtig en sprekend zijn ingedrukt”.

9. Siegenbeek (1814b: 101): "Talen, in welke klinkletters, vooral zachte en lieflijke, de overhand hebben, streelen wel het oor door eene aangename en harmonieuse opvolging van klanken; maar hebben tevens iets al te smeltends, teeders en, mag ik zeggen, verwijfds in haren toonval".

10. Siegenbeek (1814b: 101): "Zulke talen daarentegen, waarin doorgaans eene vereeniging van zware en harde medeklinkers, zonder behoorlijke afwisseling van vloeijende klinkers, wordt waargenomen, kwetsen het oor door eene onaangename ruwheid". 
that the number of vowels and consonants determined a language's softness and hardness, respectively.

Another characteristic of the Dutch was their sincerity and love of the truth, which strangers often mistook for rudeness and impoliteness (Siegenbeek 1814b: 112). Linguistically, this characteristic became manifest in the impossibility to flatter in Dutch without overstating it. Again, this was in opposition to "the French language of flattery, in which even the strongest expressions have lost almost all of their force as a result of their daily use". ${ }^{11}$ Similarly, the Dutch love of independence was reflected in a relatively flexible syntax, as opposed to the French language, which had a much more fixed syntax (Siegenbeek 1814b: 115-116). Siegenbeek also criticised the equally strong rules of French classicism, adding that the free Dutch spirit had regained its independence, also in this respect. ${ }^{12}$ The latter remark was probably a reference to the recent defeat of Napoleon and the end of the French reign of the Low Countries, which had freed themselves from the tyranny of both French classicism and French politics.

A final characteristic of the Dutch was the moral and religious character of their language (Siegenbeek 1814b: 118). Here, Siegenbeek referred to the lexicon, specifically to the absence of endogenous euphemisms for mistress, and criticised the French for having and apparently needing such words as galant and coquette. The irony was, of course, that these words were also French loans in Dutch, indicating that the Dutch were equally familiar with the concepts.

In his final remarks, Siegenbeek (1814b: 123) explained that the Dutch language was the essence of the Dutch nation, recalling that foreign rulers had tried to cause the language to depreciate and decay. He was probably referring to Napoleon's efforts to Frenchify the administrative and legal domains, and to prescribe the teaching of French in schools (Kloek \& Mijnhardt 2001: 437). According to Siegenbeek, the French had realised that they would never be able to fully rule the Dutch as long as the linguistic wall that kept them apart had not been broken down. ${ }^{13}$ Tearing down this wall would have led to "the entire corruption of our national character", to "the extinguishing of the final spark of love of the fatherland", and to "the

11. Siegenbeek (1814b: 101): "de Franse vleitaal, waarin ook de sterkste bewoordingen, door het dagelijksch gebruik, schier alle kracht verloren hebben”.

12. Siegenbeek (1814b: 118): "Niet lang echter heeft de vrije Nederlandsche geest zich door deze banden laten kluisteren, maar integendeel zijne onafhankelijkheid, ook in dit opzigt, loffelijk gehandhaafd".

13. Siegenbeek (1814b: 124): "zoo lang de scheidsmuur, die, in het behoud onzer tale, ons van hen verwijderde, niet geheel was omverre geworpen”. 
irreparable completion of our slavery and our fall". ${ }^{14}$ He concluded by calling for intergenerational transmission of the Dutch language until the last descendants, that is, through education (Siegenbeek 1814b: 125).

\subsubsection{Conclusions}

For Siegenbeek, as for many of his contemporaries, linguistics, literary history and rhetoric were interconnected parts of what we now call Dutch studies. Siegenbeek integrated these three domains, and argued that to focus on one necessarily implied taking into account the others. Throughout his works, the cultural nationalism is found that inspired van Santen to create Siegenbeek's dedicated chair of Dutch. Asking Siegenbeek to design the national orthography was clearly the right choice. One important theme in Siegenbeek's studies was the Golden Age Myth; another was the position of the Dutch language area vis-à-vis the French and German language areas. Here, he fitted in with the widespread and sometimes vehement anti-French discourse. Subscribing to the well-known nationalist axiom that language and nation were intertwined, Siegenbeek took the interesting effort to link the national auto-image of calmness, sincerity and religiosity to specific linguistic levels such as the phonology, syntax and lexicon of the Dutch language. This approach was continued by others, such as Schrant (1818: 14-19) in his inaugural lecture at the University of Ghent, with reference to Siegenbeek.

Siegenbeek conceptualised Dutch culture and Dutch language as homogeneous entities at the national level. There was hardly any reflection on internal linguistic variation, for example, on regional and social variation. External linguistic variation was conceptualised in terms of national languages such as Dutch and French that need to remain unmixed and pure, leaving no room for contact-induced changes.

\subsection{Final remarks}

In the period under investigation, from c. 1750 to c. 1850, Dutch studies became a scholarly, academic discipline. This discipline incorporated the study of language as well as the study and practice of literature, literary history and rhetoric. Thus, the study of the Dutch language was closely connected to and often a propedeutical stage of the study of literature and rhetoric. It emanated from the eighteenth-century

14. Siegenbeek (1814b: 124): "geheele verbastering van ons volkskarakter", "uitdooving ook van den laatsten vonk van vaderlandsliefde", "onherstelbare voltooijing van onze slavernij en onzen val". 
tradition of normative grammar and the linguistic studies carried out within societies and published in periodicals in the second half of the century. The linguistic heritage of Siegenbeek, the canonical first professor of Dutch, absorbed the themes and approaches that had been around for decades. The results of the preceding period converged in the works of Siegenbeek, from where they spread out again to his successors, notably the professors of Dutch appointed throughout the Netherlands from 1815 onward.

The study of Dutch was almost entirely focused on the written literary language. Vondel and Hooft, the two celebrated literary authors of the Golden Age, were still considered the eternal representatives of the pure Dutch language. The formation of Dutch studies as a scholarly discipline, in other words, was entirely entangled in a view of the language that privileged the supposedly supralocal written standard, that promoted this standard as the mirror of the nation, and that prescribed this standard to members of the nation, particularly to those engaged in the educational domain. Thus, more detailed studies of particular linguistic items were usually discussions of the acceptability of specific variants. Variation was largely neglected. After all, the underlying model stipulated an original and analogical language that had become corrupted through change, and mainly through contact with other languages, notably French. In sum, the study of the Dutch language constituted a prototypical case of ethnolinguistic essentialism, with a strong focus on a supposedly homogeneous standard variety. 


\section{CHAPTER 9}

\section{The folklorisation of non-standard language}

\subsection{Introduction}

The discursive split of the sociolinguistic continuum into standard and non-standard led to lexicographical practices that ultimately focused on the supposed national standard only (Chapter 7). Likewise, the new academic discipline of Dutch studies primarily concerned the standard, both its synchronic grammar and its historical roots in sources from the past, such as the literary language of the Golden Age (Chapter 8). While the non-standard side of the sociolinguistic space was not entirely neglected in various types of discourse, it was not subject to systematic study nor did it index neutrality in the way the national standard language came to be perceived as the neutral, nationwide communication tool (Chapter 6). On the contrary, non-standard forms, when discussed, were highly significant and emblematic of deviating linguistic practices. They represented the exact opposite of the national language, constituting the downside of the Myth of Neutrality. It was not until the nineteenth century that dialectology would develop into a separate scholarly discipline. In terms of discipline formation, the discursive split of the sociolinguistic continuum into standard and non-standard eventually led to two distinct academic disciplines, viz. standard language linguistics (Chapter 8) and dialectology.

This chapter focuses on the treatment of variation, most importantly regional variation in sources from the eighteenth and early nineteenth century. Metalinguistic discourse will be the most important type of source along with examples from literary and political discourse. Section 9.4 discusses the emergence of the study of regional variation in the first half of the nineteenth century. Dialectology was established as a separate discipline only later in the century, but this was preceded by decades of primarily lexicographical explorations of regional varieties. Before taking up the growing interest in regional varieties in the nineteenth century, I will focus on the representation of regional variation in the eighteenth century. In histories of Dutch dialectology, the period before the nineteenth century is usually limited to a brief discussion of Kiliaen (see below) and the Maatschappij (see 9.3.2; cf. Grootaers \& Kloeke 1926: 1-2; Hagen 1988; Gerritsen 2001; Goossens $\&$ van Keymeulen 2006). For the eighteenth century, I distinguish three ways in which regional forms were incorporated into and/or separated from metalinguistic 
discourse: they could be erased (Section 9.3.1), embraced (9.3.2) or enregistered (9.3.3). In the next section, I first explain what I mean by folklorisation and its related concepts.

\subsection{Variation, folklorisation and two types of authenticity}

Observations of regionally conditioned language use and more generally, of forms not typically present in supralocal writing traditions obviously already occur before the second half of the eighteenth century. Herrgen (2001: 1514) argues that an awareness of regional variation can be found in medieval German sources, adding that the inherent heterogeneity of language is already present in the opposition of shibboleth and sibboleth, with initial /s/ instead of / //, in the Biblical Book of Judges $(12,6)$. In Middle Dutch sources, too, evidence can be found that writers were aware of and familiar with other dialects than their own (Willemyns 2013: 69). Similar evidence is found in the first fully-fledged grammar of Dutch, the Twe-spraack vande Nederduitsche letterkunst ('Dialogue about Dutch grammar') published in 1584 (Dibbets 1985: 504). A noticeable example in the Dutch metalinguistic tradition is the famous Dictionarium Teutonico-latinum $\left(1574,{ }^{2} 1588\right)$ by Cornelis Kiliaen, who assigned labels such as Flemish, Hollandic and Frisian to forms that differed from the Brabantic forms he used himself (van der Wal \& van Bree 2008: 193-195). As discussed in 6.4, the general tendency in sixteenth- and seventeenth-century metalanguage was to establish a shared space of 'neutral' forms for interdialectal communication.

A more systematic approach to regional varieties consisted of inventories of lexical items that deviated from the supralocal writing tradition, which were often referred to as idiotikon in Dutch and German (Herrgen 2001: 1526). An early German example is the Glossarium Bavaricum by Johann Ludwig Prasch (1689, see Herrgen 2001: 1526). Early English examples are the Vocabularium Saxonicum by Laurence Nowell (c. 1565), John Ray's A collection of English words not generally used (1674) and the Glossarium Brigantinum by William Nicholson (1677; cf. Shorrocks 2001: 1553-1554).

The production of regional lexicons increased throughout Europe from the middle of the eighteenth century onwards. A well-known example is the Idioticon Hamburgense (1754) by Michael Richey, which was primarily an antiquarian reaction to the gradual development of supraregional forms of language use (Herrgen 2001: 1515-1516). In the early nineteenth century, Franz Josef Stalder's Versuch eines Schweizerischen Idiotikon mit etymologischen Bemerkungen untermischt. Samt einer Skizze einer Schweizerischen Dialektologie (2 vols., 1806, 1812) and Johann Andreas Schmeller's Die Mundarten Bayerns grammatisch dargestellt (1821) and 
Bayerisches Wörterbuch (4 vols., 1827-1837) already went beyond the lexical orientation, incorporating regional morphology and phonology (Herrgen 2001: 1516; cf. Haas 1994). In the English language area, too, collections of regional vocabulary were compiled, such as Francis Grose's A provincial glossary (1787; Shorrocks 2001: 1554). Likewise, Norwegian, Finnish and Slavic dialectology, which came into existence in the nineteenth century, go back to earlier inventories of lexical items (Weijnen 1966: 4; Priestley 2001; Syrjänen 2012). The Dutch tradition of compiling idiotikons will be discussed in 9.2.2 and 9.3.

Where did the increase in the production of idiotikons between c. 1750 and c. 1850 come from? In this period, "the cultural distance between elites and people had widened to such a degree that it was possible for European intellectuals to discover popular culture as something exotic and enthralling" (Burke 1992: 301). Popular culture thus became a topic of interest for members of the middle and upper ranks (Burke 1992, 2009). Typical representatives of this new intellectual curiosity are the brothers Grimm and Hoffmann von Fallersleben with their interest in Germanic folk tales and dialects, but collections of folk songs, folk tales and folk vocabulary were compiled throughout Europe (Burke 1992: 295-296, 2009: 23-25). In general, the inspiration for such collections of authentic folk material was overtly nationalistic (Burke 2009: 34-37).

Burke (2009) and Bendix (1997) interpret the growing concern with 'the' language of 'the' people, in the sense of "the members of the subordinate as opposed to the ruling classes" (Burke 1992: 293), as but one aspect of a wider and nationalistically inspired interest in popular culture, and even more generally, as part of the developing study of ethnography (Dekker 2002; Bancroft \& Hopkin 2012). Similarly, Koolhaas-Grosfeld (2010: 9) argues that across Europe, the Netherlands included, national identities increasingly became the topic of intellectual concern in the late eighteenth century, often because of exasperation due to French cultural dominance.

The specifically Dutch remedy against the supposed Frenchification implied a return to the national virtues that had led to the prosperity of the seventeenth-century Golden Age, such as thrift, the work ethic and patriotism (Koolhaas-Grosfeld 2010: 9; cf. Chapter 5). In this context, anthropological and ethnographic works were created describing the historical origins and synchronic characteristics of the Dutch nation. In 1769, J. F. Martinet had outlined the desiderata of an ethnography of the Dutch nation, which included a full description of the differences in pronunciation "of the language of our country" (Martinet 1769: 207). Between 1769 and 1811, Johannes le Francq van Berkheij published nine volumes of his Natuurlyke historie van Holland ('Natural history of Holland'), the first voluminous ethnographical description of the Dutch people. While strongly interested in the supposedly extreme diversity of the Dutch people and their customs, and while 
focused on describing this diversity, le Francq van Berkheij adopted it only against the background of a historical analysis of the rise of the original, homogeneous Batavian nation (Koolhaas-Grosfeld 2010: 108-109). It is, in other words, diversity bound by the limits of nationalism.

When in 1805 Evert Maaskamp published his Afbeeldingen van kleeding, zeden en gewoonten in de Bataafsche Republiek met den aanvang der negentiende eeuw ('Pictures of clothing, customs and habits in the Batavian Republic at the beginning of the nineteenth century'), he continued the approach taken by le Francq van Berkheij. Maaskamp also stressed the immense diversity found in the Netherlands, which was however still part of the one Dutch nation (Koolhaas-Grosfeld 2010: 167). An important aspect of Maaskamp's work is the presumed historicity of the local and regional costumes he presented, to the extent that national and original appear to be used interchangeably (Koolhaas-Grosfeld 2010: 167). Such costumes were viewed as relics of the past, which Koolhaas-Grosfeld (2010: 167) connects with an important technique used in the construction of national images, viz. archaisation. Claims to historicity are often intertwined with claims to nationality (cf. Section 2.3). This is also clear from the antiquarian approach to local vocabulary taken in the tradition of idiotikons, which is usually interpreted as a Herderian, romantic interest that connects "the ancient and the dialectal" (Shorrocks 2001: 1555, cf. Herrgen 2001: 1515-1516; Priestly 2001: 1563-1564).

Singling out regional costumes and other customs as remarkable or noteworthy - in a word as different - is, of course, only possible against a supposedly common background. Koolhaas-Grosfeld (2010: 168-169) interprets the description of remarkable aspects of particular members of the nation as a case of auto-exoticism. Leerssen (2007: 325) argues that exoticism implies that the "other culture is appreciated exclusively in terms of its strangeness; it is reduced to the aspects wherein it differs from the domestic standard. As a result, exoticism will foreground and privilege the saliently different ('exotic') aspects, pin a society down to its local colour and its picturesque elements [...] Exoticism is thus also a modality of Othering, of heightening the Other's strangeness". While exoticism relates to an imagined community and its self-image, auto-exoticism may be used "to describe the self-image of countries with a subaltern history, who have interiorized the exoticist terms in which they are habitually represented to (and by) dominant outsiders. [...] Other forms of 'internal exoticism' can be social (novels set in the thrillingly unfamiliar world of the slums or in high society) or rustic and regionalist" (Leerssen 2007: 325).

In historical studies of the increasing interest in popular culture in the late eighteenth and nineteenth centuries (Bendix 1997; Burke 2009), folklore is a key term. I will call the specific auto-exoticist process characterising this period folklorisation (cf. e.g. Doja 1998; Rogers 1999; Godreau 2002). Crucial to the concept of folklorisation is that after decontextualisation and objectification, the folklorised elements 
are put "in a subordinate position within the national totality" (Rogers 1999: 72). Thus, linguistic folklorisation affects those forms that are deemed non-standard within standard language ideology: these are the exotic, remarkable, non-neutral variants that may be described and studied, though not as part of a study of the Dutch language, but rather as part of a study of deviations from the Dutch language.

Interestingly, authenticity is a leading concept in Bendix's (1997) study of the formation of folklore studies. She attributes a strong influence to Herder for "assigning authenticity to the pastoral way of life in one's own region" (Bendix 1997: 35). In Chapter 6, I have argued that the notion of authenticity, along with anonymity, was part of standard language ideology. The Dutch national language was not only constructed as an anonymous tool that could be learned by anybody in the interest of emancipation, but also as the authentic language of all the members of the Dutch nation, despite the fact that many of them had grown up speaking a different variety, viz. a regional dialect. Both ideological constructs distinguished by Woolard (2008), i.e. anonymity and authenticity, became associated with the national standard. On top of that, however, specific regional lexical items were also associated with authenticity. We therefore need to distinguish between two types of authenticity.

The first type of authenticity relates to the national standard variety, the second type to non-standard forms, and in the context of this chapter primarily to regional lexical items. Standard authenticity is a wider form of authenticity encompassing all levels of the language, including pronunciation, spelling, grammar and the history of the language. It is the mythical other side of a language that is simultaneously reduced to an emancipatory communication tool within a discourse of anonymity. Non-standard authenticity is more limited and relates almost exclusively to vocabulary that is not found in the standard, collected in so-called idiotikons. It does not have a counterpart; it is not linked to any kind of anonymity. Standard authenticity, while rooted in the glorious past of the Golden Age, is focused both linguistically and socially on the future. It designates the forms that have historical rights to be part of the newly reconstructed national standard variety, and that need to be taught to all those members of the nation who have not yet mastered the standard. Non-standard authenticity, on the other hand, is rooted in the present and focused on the past. It entails an archaising perspective of forms that are interesting for being deviant, and that may therefore be preserved in written idiotikons. Finally, the authenticity of the standard variety is linked to its neutrality: the authentic variants are also neutral variants. Regional variants, on the other hand, were constructed as deviant, exotic and, as we will see, often also as naive and staged. Sections 9.3 and 9.4 discuss the representation of regional variation in eighteenth- and nineteenth-century metalanguage. 


\subsection{Representing regional variation in the eighteenth century}

From c. 1800 onwards, interest arose in the description of regionalised language use. Before discussing this 'rise of dialectology' in Section 9.4, I will first focus on the preceding period. The main question will be how regional language variation was represented in the eighteenth century, both in metalinguistic discourse and in other text types, such as literary texts. The representation of variation can take three different forms in this period: variation can be erased (9.3.1), embraced (9.3.2) or enregistered (9.3.3).

\subsubsection{Erasing variation}

The first type of 'representation' actually involves a lack of representation, that is, it involves invisibilisation (Havinga \& Langer 2015) and erasure (Irvine \& Gal 2000). Erasure refers to an ideological process whereby specific linguistic forms or varieties are discursively erased, that is, for ideological reasons they are not part of discursive representations of the sociolinguistic space (see Chapter 2). When eighteenth-century ministers, schoolteachers and university professors engage in the grammatical description of Dutch, they focus almost exclusively on the written language found in published works. They take the literary and religious works of the seventeenth century, the so-called Golden Age, as their main examples (Chapters 4 and 5). They attach great importance to a uniform orthography and to nominal inflection, largely disregarding phonetic and phonological variation and the almost complete loss of case endings in the spoken language. The near absence of discussions of regional variation is, of course, closely connected to the textual orientation of normative grammar in this period: descriptions of the grammatical system of Dutch were not only founded on written sources, often from the past, but were also primarily targeted to writers, and intended to regularise conceptually written language (Koch \& Oesterreicher 1985). The latter includes genres such as sermons, which are spoken, yet preconceived and written down at a writing desk.

The Vondelian tradition of normative grammar entirely fits this ideological scheme (Chapter 4). Nevertheless, observations of regional variants are not completely absent. A typical example is the following entry from van Hoogstraten's list of nouns and genders:

MARKT v. Op de groote markt, Hooft Historien 103. De zon zal u de markt zetten, Vondel in Virgilius I. boek der Lantgedichten. Derhalven niet het markt: gelyk men te Groeningen spreekt.

(van Hoogstraten 1700: 58) 
The entry demonstrates that the noun markt 'market, market place' is feminine ( $v$. for vrouwelijk 'feminine'). This is evidenced by two quotations from Hooft and Vondel with the article $d e$ 'the' in object position, which only occurs in the feminine according to contemporary prescriptions. The final line says that het markt with the neuter article het 'the' is therefore incorrect, "as they say in Groningen". The entry shows that van Hoogstraten was both aware of this particular regional variant and proscribed its use in the written Vondelianist register.

It is this particularly anti-regional and, in many respects, pro-Holland attitude where Holland is synonymous with supraregional and neutral - that led to a virulent debate between van Hoogstraten and another language commentator, Johannes Hilarides, based in the province of Friesland (Dibbets 1996; Rutten 2006: 378-380). This debate, in which both opponents accused each other of being rude and insane, was not about Frisian minority rights or language choice, but about regional differences within supraregional Dutch. Hilarides also discussed Dutch, but questioned certain Hollandic variants, while promoting Frisian Dutch alternatives.

Still, the attention paid to regional variation remained marginal, and in general, Hollandic variants were promoted. A noticeable exception, to some extent, is the famous magnum opus of ten Kate (1723), who was considerably less normative than many of his contemporaries, although he did adhere to the Vondelianist scheme in many respects. Like Verwer (1707) and Huydecoper (1730), ten Kate (1723) placed great importance on language history. Contrary to Verwer and Huydecoper, he systematically took into account the historical differentiation of regional dialects, most prominently the western varieties used in the Holland and Zeeland areas. One consequence of this was a spelling proposal that incorporated vocalic differences common in Zeeland and the southern parts of Holland, but absent from most of northern Holland, including his home town of Amsterdam. Importantly, however, ten Kate's interest in regional variation is entirely historical. He did not describe regional variation in the Dutch of his time per se, but as a function of his historical analyses and of his efforts to outline the foundations of a supraregional Dutch language (Daan 1992; van Leuvensteijn 2008).

In the second half of the century, when societies and periodicals became engaged in metalinguistic discussions, ten Kate, Verwer and Huydecoper were the three most important anchors for many commentators. As discussed in Chapter 8, regional variation in Dutch was also a topic of marginal importance in this period. With the increasing temporal distance to the seventeenth-century Golden Age, its pre-eminence as a period of linguistic and literary authenticity equally increased. It is, however, not a Herderian authenticity bound up with peasant folk purity and their pure language forms (Woolard 2008). Instead, it is a type of authenticity that revealed itself in a past period of regularity, and that needed to be revived (see 8.2.2, 8.2.4 and 8.3.2). 
In the normative tradition and the learned discussions in the periodical press in the second half of the century erasure was primarily discursive, in accordance with the meaning attributed to it by Irvine \& Gal (2000). Regional variation was generally rendered invisible in metalanguage. In addition, concrete action against regional variation was sometimes taken, particularly in educational settings. In such cases, erasure and invisibilisation constituted concrete proscriptions against particular variants. The most well-known Dutch example in this context is the so-called Haagsch Nederduitsch woordenboekje ('The Hague-Dutch dictionary'). This booklet of almost 20 pages comprised an alphabetical list of words characteristic of the city of The Hague in the south of Holland, to which corrections in normalised Dutch were added. It was probably published around 1780 (Kloeke 1938: 47) for the benefit of schoolteachers, but according to the preface already written half a century before, i.e. around 1730, by J. A. v. H., "school- and language teacher during his life" (Haagsch Nederduitsch woordenboekje, p. 3; my translation). He aimed to cure fellow schoolteachers as well as pupils from de gemeene Straattaal en slechte Woorden 'common street language and bad words'.

Most proscriptions in the Haagsch Nederduitsch woordenboekje concern phonology. For example, the first entry, under the header uitspraak 'pronunciation', is Affrekaan, which is corrected to Africaan under the header verbetering 'correction'. Apart from orthographical issues such as the consonant spelling, the example demonstrates and forbids the reduction to schwa of the second vowel, possibly also the proscribed realisation of the first vowel as / $\alpha /$ instead of /a/. The Haagsch Nederduitsch woordenboekje provides a unique perspective of what may have been common teaching practices in South Holland schools, demonstrating that regionally marked phonology and, in the case of Affrekaan, common features of spoken Dutch, were preferably unlearned (see also Chapter 10).

In most normative publications as well as in the more scholarly oriented periodicals, regional variants, if acknowledged at all, were considered deviant and avoidable. This was wholly different in the lexicographical discussions of the time.

\subsubsection{Embracing variation}

A completely different approach was taken in the second half of the century, when plans were developed for a new national dictionary of the Dutch language. As argued in Sections 7.2 and 7.3, these plans were usually remarkably inclusive, arguing for the incorporation of all lexical items ever used in any region of the Netherlands. In other words, regional variation in the lexicon was acknowledged, even embraced. The materials collected for the new dictionary mark the beginnings of the Dutch tradition of idiotikons. 
Quite a few materials were gathered over the years, particularly when the plan for a new dictionary developed from a personal idea into a project on behalf of the Maatschappij der Nederlansche Letterkunde (Sections 7.2.1-7.2.3). At the annual meeting of the Maatschappij in 1773, the plan for a new dictionary was adopted, although a new and more concise plan was needed (Handelingen 1773: 8-10, cf. $7.2 .3,7.2 .4)$. The members of the Maatschappij were very enthusiastic. At the annual meeting of 1774, the secretary presented a long list of members who had agreed to send in word lists, either with obsolete vocabulary taken from older writers or with regional lexical items. Frans van Lelyveld, for example, said he would scrutinise the 1677 edition of Hooft's Nederlandsche Historien ('Dutch history'), while Kluit was going to examine the fourteenth-century text of the Spiegel historiael by Lodewijk van Velthem (Handelingen 1774: 14). Older and contemporary vocabulary related to the northern and eastern areas of Friesland, Groningen and Drenthe was going to be collected by the members van Halsema, van Lier and Lubbers, while southern vocabulary related to Brabant and Flanders would be inventoried by te Water and van Iperen (Handelingen 1774: 15). What is more, some members, including strong advocates of a new dictionary such as van Iperen and van den Berg (cf. 7.2.1, 7.2.2), had already sent in lists of words taken from historical sources or characteristic of certain regions (Handelingen 1774: 15).

For about fifteen years, the transactions of the annual meeting of the Maatschappij mention all the new materials collected in the past year (e.g. Handelingen 1775: 1819, 1777: 11-12, 1778: 6-8). In the mid-1780s, the number of new submissions decreases, which is sometimes lamented in the Handelingen (1785: 6-7, 1786: 2, 1787: 4). In the late 1780s, it is repeatedly said that the source materials of the new dictionary have not aanmerkelijk vermeerderd 'significantly increased', except for one or two submissions (Handelingen 1788: 4, 1789: 6, cf. 1790: 2). From the early 1790s onwards, the dictionary is hardly mentioned any more and no new word lists are sent in. Weiland's proactive attitude at the 1796 meeting must have made him a true guardian angel (see 7.3 and 7.4).

Many of these word lists are now kept at the Leiden University Library, which holds the archives of the Maatschappij. ${ }^{1}$ Over recent decades some of these lists

1. In 2007, André Bouwman and Anton van der Lem described the collection of the Maatschappij, of which the text is published online (https://socrates.leidenuniv.nl/view/action/singleViewer. do?dvs=1467372273671 36\&locale=en_US\&VIEWER_URL=/view/action/singleViewer.do?\& DELIVERY_RULE_ID=10\&search_terms=\%20bibliotheek\%20maatschappij\&frameId= 1\&usePid1=true\&usePid2=true). The inventory numbers LTK 71-134 comprise manuscript sources with historical and regional word lists, many of which were compiled in the context of the dictionary plans. 
have been published, though not necessarily in their original form. ${ }^{2}$ Bezoen (1952) edited the source materials from the province of Overijssel in the northeast. Heeroma (1960, 1967, 1968a, 1968b) published lexical items related to Brabant, Groningen, Drenthe and the Veluwe area. Heeroma also worked on an edition of the northern Hollandic vocabulary, which was only published by de Vaan (2013). The Handelingen of 1781 (p. 6) mention words from Walcheren in the province of Zeeland collected by Adriaan Kluit; van de Bilt (2003) offers a list of 68 nouns and verbs from Walcheren. These regional word lists usually comprise entries - mostly nouns and verbs - with a short description of the meaning or, even more concisely, a more commonly used alternative. Occasionally, grammatical information is provided, for example on the word class or etymology. The following two examples are taken from Verster's 1776 collection of words from Brabant (see Heeroma 1968a: 12, 13):

\section{Allendig. Ellendig}

Kiliaan op het woord Allende.

Dit woord word in de meierije in enen bijzonderen zin en zeer algemeen gebruikt. Allendig schoon, of groot, voor zeer schoon.

Allendig. Awful

See the dictionary by Kiliaan s.v. Allende.

This word is commonly used in a specific sense in the Meijerij (the area around Den Bosch). Allendig schoon, or groot 'awfully beautiful, or big', for zeer schoon 'very beautiful'

Awaij. Misschien.

Awaij. Perhaps.

Despite the inclusive approach and the members' enthusiasm for collecting regional variants, it is important to stress that their interest in regional variants was limited to the lexicon. From a modern dialectological perspective, the inventories of regional items count as eighteenth-century curiosa 'curiosities' (Heeroma 1968a: 7). The aim of the collectors was not linguistic geography, but language cultivation (Heeroma 1960: 65). The folklorising and antiquarian approach was already commented upon in the early heydays of modern Dutch dialectology, when Kloeke (1926: 2) wrote about the eighteenth-century collectors:

2. For example, the word list from Zeeland sent in by Kluit has not been preserved. As early as the eighteenth century, it was turned into separate card files to advance the compilation of the dictionary. The edition by van de Bilt (2003), therefore, offers a reconstruction of what may have been Kluit's contribution to the new dictionary. Heeroma (1968a: 9-10) describes a similar situation for the Brabant material. 
Uit geen enkele mededeeling van dien tijd blijkt trouwens, dat men de groote wetenschappelijke beteekenis der dialecten ook maar eenigszins besefte. Men vond het aardig "woorden" te verzamelen; om de "curiosa et rariora" was het voornamelijk te doen, men verhollandschte ze en deponeerde ze dan als gedroogde preparaten in het taalherbarium.

From not a single contribution from that time does it become clear, for that matter, that they even remotely realised the major scientific relevance of the dialects. They liked to collect 'words'; it was mainly about the 'curiosa et rariora'. They Hollandicised these and then deposited them as dried specimens in the language herbarium.

Dialect grammar was not taken into account, in spite of Hinlópen's revolutionary proposal to extend the inclusive approach to grammatical items (Section 7.3.2). Moreover, the aim was still to create inventories of lexical items in so far as these were not part of the common or national language. There was no interest in creating regional dictionaries as such, let alone in analysing regional grammatical systems. The attention paid to regionalisable lexical items was only justified by the project to create a national dictionary into which deviant lexical items characteristic of specific regions could be incorporated. The approach was thoroughly auto-exoticist, albeit that the exotic elements would eventually be admitted to the envisaged national dictionary.

\subsubsection{Enregistering variation}

There is a long tradition of inserting localisable forms into supralocal writing. In Section 6.4.2, in the context of the hierarchisation of forms and varieties, I referred to the seventeenth-century practice of employing vernacular features in literary texts, particularly in farces, to portray lower-order characters and/or immigrants. This literary technique was continued in the eighteenth century, an early and significant example being the periodical De Hollandsche Spectator ('The Hollandic (Dutch) Spectator', 1731-1735) by Justus van Effen. De Hollandsche Spectator was a moralistic periodical, in which van Effen promoted the norms and values of the middle ranks, denouncing both the mob and the Frenchified elites (Leemans \& Johannes 2013: 188). In the seventh issue, for example, published 1 October 1731, van Effen argued against horse racing, which he construed as a combined lower/upper-class phenomenon that the middle ranks should avoid (cf. van Effen 1984: 49-56). The issue comprises two letters, one by the innkeeper and horse trader Klaas Janssen, supposedly from somewhere around the city of Amsterdam, the other by the 'young Sir' Chevalier Gryspaart 'lit. Cavalier Greyhorse'. The latter is relatively short and written in a somewhat higher register, and the Frenchified 
young cavalier is effectively unmasked when he claims to have invented a new way of handling the whip, viz. een nieuwe Franse slag 'a new French whiplash' (van Effen 1984: 56). The Dutch expression to do something met de Franse slag 'in a French way' still means to do something in a slapdash manner.

The letter by Klaas Janssen, also composed by van Effen, is more elaborate, and replete with localisable forms. However, an analysis of the phonological, morphological, syntactic, stylistic and lexical features used to suggest a specific locality shows that van Effen employed a straightforward technique (Rutten 2008b). For example, out of a total of 59 morphological items that could be considered different from contemporary writing practices, 33 are of the exact same type, viz. past participles with a reduced prefix, viz. $e$ - instead of $g e$ - in forms such as eweest 'been'. Reduced forms of the past participle prefix were and still are common in many Dutch varieties (MAND II: maps 74a, 74b). However, such forms are extremely rare in post-medieval writing, including in private letters from lower- and middle-ranking writers in the second half of the seventeenth century (Rutten \& van der Wal 2014: 65-67).

A further thick and unpublished manuscript with Dutch texts also stems from the 1730s, written by Jan de Boer, a native of the city of Haarlem, born in 1694 . The volume comprises two texts in the Haarlem dialect. One of these, a poem of 392 lines, was published in 1958 (De Haan 1958). The poem, dated 16 February 1732, was called Den onverstandigen roomsch katholijken boer ('The unwise Roman Catholic farmer'). An introductory note between the title and the first verse explains that the farmer in question is Spreekende van zaaken diên hij zelver niet verstaat 'talking about things he does not understand himself'. While Daan (1958) in a linguistic commentary concludes that the representation of local features appears to be relatively reliable, it is also clear that the text is a literary construction parodying both the language and the viewpoints of a different, presumably lower or less powerful social group.

A number of texts produced in Groningen and Maastricht in the second half of the eighteenth century appear to be slightly less parodic. In the city of Groningen in the northeast of the language area, the farce Et en Fret was written in or around 1793 (Et en Fret 1957: 12), partly in what appears to be a rather faithful representation of the Groningen dialect (Niebaum 2009). The play is set in a middle class environment and thus differs from earlier farces in which vernacular features were often used to create stereotypes of the lower ranks. Nevertheless, some characters do not speak the local dialect but a supralocal variety of Dutch, while many characters embody familiar stereotypes, such as people from Groningen being stingy, and people from the neighbouring area of Drenthe being clumsy and dumb (Niebaum 2009: 7). In addition, the stage directions are all set in a supralocal variety of Dutch (e.g. Et 
en Fret 1957: 19), testifying to the perceived neutrality of this variety, even if the play itself demonstrates the suitability of the Groningen dialect for a literary genre.

Perhaps even more interesting is the southeast of the language area. Spronck (1962) mentions a few texts written in the dialect of the city of Maastricht from before 1800 . Crucially, these are not literary pastiches inserted into a supralocal Dutch matrix text, thus indicating the otherness of the Maastricht dialect. Such texts - farces, for example - can also be found in Maastricht, but some of the examples mentioned by Spronck (1962) relate to occasional poetry, testifying to the fact that for many speakers of the region, the local dialect was much more common and also appropriate, even in ritualised circumstances such as festive occasions (see also Marynissen 2004; Kessels-van der Heijde 2015).

An extraordinary example is the so-called Sermoen ('Sermon', cf. Endepols 1955: 549-557), a text completely written in the Maastricht dialect, dated 1729, but probably written around 1775 (Spronck 1962: 440). The misdating is probably part of the carnival context to which the text belongs. The Sermoen entails a typically eighteenth-century defence of the 'own' language, including grammatical examples and the topos that it is not subordinate to any other language, as well as strong repudiations of a handful of other languages and of fellow citizens who prefer those other languages. The languages argued against are English, Dutch and particularly French. With its strong anti-French rhetoric and its fear of Frenchification (see Sections 5.2 and 5.3), the Sermoen echoes the discourse characterising the emerging nationalist ideology, but in a true carnival spirit reshapes this discourse in a local context. Even if the Sermoen ridiculises this type of discourse as such, it still bears witness to regional resistance to influences from elsewhere, including from the Holland area.

While these literary experiments with dialect use can be considered the beginnings of the typically nineteenth-century tradition of dialect literature, the same period of the late eighteenth century brought forth a use of localisable forms that was even more explicitly political than in the earlier Spectators, in line with the strong politicisation of social and cultural life in the second half of the century. Particularly in the 1780s and 1790s, the political press thrived in the northern Netherlands, and an explicitly political perspective replaced the predominantly moral perspective of the earlier Spectators (van Sas 2004: 197-198).

One example is De Vriend des Volks ('The Friend of the People'), fifty issues of which appeared between 5 March 1795 and 11 June 1796 (van Sas 2004: 350). The patriotic and republican periodical De Vriend des Volks was published in Middelburg, in the southwestern province of Zeeland. The main author and editor was J. H. van der Palm, who - only a couple of years later - would call for a national language policy (Section 2.5). In the first issue, the editors of De Vriend des Volks 
(1796: 7-8) explained that they wanted to inform the general public about political matters in a plain and simple style, adding that this did not imply "coarse and clumsy language", and stressing that they did not think so low of the Dutch people that a beschaafde 'cultivated, polished' style would be out of their reach. The didactic approach taken in political matters was mirrored on the linguistic level: when the editors created a fake letter to themselves, supposedly written by a labourer still ignorant of the advantages of republican patriotism, they used a markedly Zeeland repertoire to identify the fictitious writer as uneducated, both in political and in linguistic matters (De Vriend des Volks, issue 21, see 1796: 177-184; see also Meertens 1960). In a note, the editors explained that they had had to purify the letter of certain spelling mistakes so as to render it comprehensible, while being careful not to rob it of its naivety (1796: 180-181).

A similar example is the periodical De onverwachte courier ('The unexpected courier'), of which 114 issues were published between 1795 and 1798. De onverwachte courier was based in Groningen in the north east of the language area. Its authors and editors used the same technique as those of De Vriend des Volks (cf. Van der Kooi 1983). They included letters and dialogues by common people with ordinary names such as Hannes, Piet and Klaas (e.g. issues 23 and 40, published in 1796). Their texts were set in a supralocal variety with specific forms indexing the locality of Groningen. While the Zeeland letter from the De Vriend des Volks offered a range of phonological and morphological features clearly linked to the south west (Meertens 1960), the authors/editors of De onverwachte courier mainly restricted themselves to three techniques that were moreover not applied systematically, viz. representing reflexes of $\mathrm{Wgm} .{ }^{*} i$ by $<\mathrm{ie}>$, thus suggesting lack of diphthongisation, forming past participles without the prefix $g e-$, and mangling presumably difficult words such as French loans (Pattertismus instead of Patriottismus, patterjot for patriot; cf. Van der Kooi 1983: 127).

The late eighteenth century saw a wealth of similar periodicals and pamphlets that appropriated localisable forms. Well-known examples also include political pamphlets in the form of fictional dialogues set in a pub or aboard a canal boat (kroegpraatje 'lit. pub talk', schuitpraatje 'canal boat talk'). While these genres date back to the seventeenth century, the cultural and political fields that they were part of changed dramatically in the late eighteenth century. The nationalisation projects of the second half of the century transformed the use of localisable elements from a literary technique aimed at the social stereotypisation of individuals, as in the tradition of farces, to a political technique aimed at singling out individuals in need of cultivation, politically as well as linguistically. Periodicals such as De Vriend des Volks and De onverwachte courier fed on the identification of nation and language: those who still needed to be enlightened about the desirability of Dutch national 
republic were also in need of linguistic education. Van der Palm's career is significant in this respect.

From a language ideological perspective, it is also important that the texts inserted localisable elements into a supralocal matrix variety, probably in order to create an authentic atmosphere or couleur locale. In this respect, the technique does not differ from the earlier farces and Spectators. Synchronically, however, an interest in local and/or regional forms was largely restricted to collectors of lexical items (see Section 9.3.2). Those collectors, however, assembled attested lexemes, whereas the local forms in the periodical press were merely created in order to suggest authenticity. Thus, the authenticity in question was staged. Whereas this staged authenticity was not limited to vocabulary, the resemblance to non-standard authenticity is obvious (see Section 9.2). Non-standard authenticity was rooted in the present, but focused on the past, offering a view of archaic language forms that were soon to die out. Likewise, the immature political ideas of the common people and the uncivilised language in which these were expressed were meant to disappear under the influence of the periodical press.

The fact that these localisable forms were inserted into larger pieces of discourse set in a supralocal variety of Dutch, and were sometimes even commented upon in this supralocal variety, creates a situation of two varieties or registers meeting within one text. The concept of enregisterment was introduced by Agha (i.a. 2003, 2005). For example, the spread of an English Received Pronunciation from the late eighteenth century to the late nineteenth century can be thought of as a gradual process whereby RP became a socially recognisable register (Agha 2003). Similarly, the conscious use of localisable or dialect features in Pittsburgh (Johnstone 2009) and Sheffield (Beal 2009) comprises the identification and establishment of a particular register, that is, a set of recognisably local forms. Johnstone (2009: 160) adds that

[i]n order to become noticeable, a particular variant must be linked with an ideological scheme that can be used to evaluate it in contrast to another variant. [...] Once it comes to be interpreted and evaluated with reference to an ideological scheme, a linguistic form has been 'enregistered'. A form that is enregistered is one that is linked with a way of speaking or 'register' associated with a personal or social identity.

In the case of the spread of RP, part of this process consisted of pointing out deviations from the standard such as $h$-dropping. Thus, the ideological scheme underpinning a specific register also involves demarcating the register from other forms.

In the case of Dutch vernacular forms being inserted into supralocal discourses, this interplay of what is and what is not part of the register is emphatically 
present, and is to a certain extent turned upside down. The already acknowledged or 'received' register is the matrix variety of supralocal written Dutch, discursively constructed as the neutral form of the national language (Chapter 6). As a result, deviations from this 'standard' are also enregistered, albeit not as a fixed set of forms that can be tied to a specific place as in the case of Pittburghese, Geordie and Sheffieldish (Johnstone 2009; Beal 2009). But the social significance of registers also depends on contrastivity, on the possibility of differentiating one register from another (Gal 2016: 120-121). While the neutral and standard forms have been enregistered and linked to the ideological scheme of the nation state, deviations from this 'neutral' variety become enregistered as a set of forms indexing non-standardness and otherness that can at best be recruited to index authenticity and naivety. It is the discursive split of the linguistic continuum into standard and non-standard that facilitates the enregisterment of non-standard forms.

Agha (2005: 46-47) stresses that a register entails a specific repertoire of forms with a well-defined social range, that is, the linguistic forms that make up the register index certain social characteristics. In addition, there is a social group that recognises and possibly uses the repertoire and its indexicalities. In the Dutch case discussed here, there is a collection of forms indexing non-standardness, which is recognisable as such by readers of the periodical press. It is a register that merely exists ex negativo, viz. in its status of deviating from the standard. The authors and editors of political periodicals and pamphlets play with this ideology and in the case of De Vriend des Volks, use metalinguistic commentary that reveals their ideology.

In many eighteenth-century representations of localisable language, the 'deviant' register is part of a larger discourse that is set in a supralocal variety. The authenticity it indexes is staged - it is purposefully created and presented to isolate it from the supposedly neutral register of the supralocal writing tradition.

\subsection{The emergence of the study of regional varieties}

Both the inclusive, yet auto-exoticist approach towards regional lexical items (9.3.2) and the omnipresent acts of enregisterment (9.3.3) testify to the ongoing folklorisation of localisable language. In the course of the nineteenth century, and in particular in the second half of the century, dialectology emerged as an autonomous discipline. This section focuses on the earliest beginnings of the study of regional varieties, occurring in the first decades of the century, against the ideological background outlined in Sections 9.2 and 9.3.

Frisian has a long writing tradition, dating back to the Middle Ages, and with the well-known author Gysbert Japicx (1603-1666) as a post-medieval successor, but 
also as an exception to the increasingly dominant western Dutch writing tradition. The Frisian writing tradition was revived in the course of the nineteenth century. Early nineteenth-century examples of the use of Frisian in a non-parodic context can be found in Wassenbergh (1806). Wassenbergh was one of the first professors of Dutch (see 8.1)., based at the University of Franeker. He also wrote about Frisian. Wassenbergh (1806: 1-121) comprises an Idioticon Frisicum of Woordenboek van bijzonder in Friesland gebruikelijke woorden en spreek-wijzen, ('Idioticon Frisicum or Dictionary of words and phrases particularly in use in Friesland'), which is often mentioned as one of the earliest nineteenth-century texts on dialectology (Kloeke 1926: 2). As the author explained in the introduction, the Idioticon Frisicum had been compiled as part of the lexical activities of the Maatschappij (see 9.2.2). Wassenbergh continued the work carried out in the 1770s, 1780s and 1790s, and fitted in completely with its auto-exoticist approach. Next to the heerschenden Hollandschen tongval 'dominant Dutch variety' (Wassenbergh 1806: 1), there were regional variants worthy of being inventoried. Moreover, he claimed that while the words and phrases collected by him were perhaps considered as obsolete by some language experts, their continued use in Friesland was evidence of the Frisians remaining faithful to their Karakter 'character' (1806: 5).

With this familiar appeal to historical continuity, Wassenbergh represents the second type of 'non-standard' authenticity, which primarily considers regional lexical items as archives, that is as interesting witnesses of a disappearing past. It should be noted that Wassenbergh mainly collected forms found among speakers of Dutch and among speakers of the Dutch-Frisian contact variety used in the larger cities and towns in Friesland, refraining from collecting forms used by the Boerenstand 'peasantry' (Wassenbergh 1806: 4; cf. Kloeke 1926: 2; Dykstra 1999: 191). Better evidence of Wassenbergh's primary strong focus on 'exotic' Dutch, not Frisian, can hardly be found.

A few years later, Ypeij's history of the Dutch language devotes some attention to regional variation, but mainly restricts the discussion to textual examples that demonstrate some regional variability (e.g. 1812: 368-374, 418-427). In the province of Groningen, word lists were compiled similar to Wassenbergh's, and likewise still inspired by the Maatschappij. In 1809, minster Nicolaus Westendorp published a short list of words, reprinted in 1822 in M. T. Laurman's volume on the language of Groningen, which also comprises mainly an inventory of regional lexical items. In his introduction, Laurman felt he had to justify his interest in regional languages. As the Dutch language consisted of many different varieties, mastering the language necessarily implied knowledge of at least some of the regional varieties, according to Laurman (1822: V). He continued: 
Onze oud-Friesche en Groningsche dialekten zijn mogelijk wel ruwer, en onbeschaafder, dan die van andere landstreken van ons vaderland; maar, bedrieg ik mij niet, ook ouder, minder verbasterd, en dus wel waardig, naar mijn begrip, dat ieder taalminnaar zijne aandacht een' oogenblik op Friesland en Groningen slaat

(Laurman 1822: VI)

Our old Frisian and Groningen dialects are possibly more boorish and less polite than those of other regions of our fatherland, but if I am not mistaken, also older, less corrupted, and therefore, as far as I am concerned, they certainly deserve that all language lovers briefly devote their attention to Friesland and Groningen.

Laurman did not argue, for example, that regional languages were living systems, used on a daily basis, and therefore interesting objects of study. His main argument is their perceived historicity, which he associated with purity. This characteristic, however, was only visible and relevant in comparison with "our glorious Dutch language" (Laurman 1822: V). He lent authenticity to the language of Groningen, but it was the typical non-standard authenticity attached to archaic forms worthy of archiving.

Nonetheless, Laurman (1822: VII) stated that the variaties used in Groningen were also grammatically different from the common Dutch language, and that a grammar of the Groningen language would be interesting. Only two years later, the University of Groningen held a prize essay contest with the Dialectus Groningana as the topic (Sonius Swaagman 2002: 6). The topic was probably chosen by Lulofs, then professor of Dutch in Groningen (see 5.3.2 and 8.1), where Ypeij was rector at that time (Sonius Swaagman 2002: 7). The winning essay, and also the only submission, was written by Jan Sonius Swaagman, a student of theology. His text in Latin was published in 1827 (see Sonius Swaagman 2002). It begins with a brief overview of the Germanic languages, their history and geographical distribution, largely founded on Lulofs (1819) and Ypeij (1812; cf. Sonius Swaagman 2002: 21, 23). The second half of the Commentatio comprised a list of words magis minusve 'more or less' characteristic of the city and province of Groningen (Sonius Swaagman 2002: 86). In between, Sonius Swaagman (2002: 48-85) presented a remarkable chapter with a description of the phonology and morphology of the language of Groningen, systematically discussing vowels, consonants, pronouns, verbal inflection and so on. It was remarkable for its relatively detailed description of the regionally used forms in their own right, and also because it would remain one of few exceptions to the folklorising rule for many years to come.

In the 1830s, the creation of inventories of regional lexical items continued. Hoeufft (1836) wrote a voluminous work - more than 700 pages - with words from the city of Breda in the province of Brabant. In the introduction, he explained that he had followed the example of Wassenbergh's Idioticon Frisicum (Hoeufft 1836: III). From 1835 onward, the well-known educationalist and linguist Arie de 
Jager edited the Taalkundig Magazijn ('Linguistic Magazine'). It discussed mainly standard language issues, though each volume devoted some space to regional varieties. Sifflé (1835) listed lexical items from Zeeland, while also mentioning a few phonetic characteristics of the region. Swaving $(1835,1837)$ provided words from Gelderland, referring to the plans for an inclusive, general dictionary, in which these words should be admitted, and deploring the fact they were not part of the existing dictionary, that is, Weiland's (see Chapter 7). An anonymous author contributed words from Groningen to the second volume of the Taalkundig magazijn (see Lijst 1837). The second and third volumes also comprised anonymous lists of lexemes related to Gelderland, in which also a few phonological, morphological and syntactic forms were discussed (Opmerkingen 1837; Aanteekeningen 1840). Beets $(1840,1842)$ published short inventories of words characteristic of the northern parts of Holland. Finally, J. A. (1842) contributed some remarks on the phonology and morphology of the regional language of Groningen, while the lexicon was still the main part of his publication. In the same period, Serrure (1841-1842) revived the notion of a general dictionary of the whole Dutch language, to which he added a list of words from Louvain (see Section 7.5).

Most of these authors primarily focused on the lexicon, while including some notes on other aspects of the language. For Swaving and Serrure, the interest in regional varieties was inspired by the inclusive plans for a general dictionary (see Chapter 7 and also Section 9.2.2). Others emphatically embraced the folklorising perspective: regional languages were interesting mirrors of a bygone age, in which archaic forms were preserved. While imbued with notions of authenticity and historicity, these archaic forms were now, volgens de tegenwoordigen staat onzer moedertaal 'according to the current state of our mother tongue' (Aanteekeningen 1840: 42) to be considered as fouten 'mistakes' (Opmerkingen 1837: 399). Appreciation of the archaic shaded in condemnation of what should have been erased, and replaced by the national language.

These evaluative changes were addressed even more explicitly by Sifflé (1835: 169), who began his essay with a seemingly neutral description of the language shift to Hollandsch among speakers of the Zeeland dialect, particularly among de hoogere kringen 'the higher circles' in the cities. He continued:

In het algemeen moet men niet vergeten, dat de Zeeuwen, vooral na het verbeterd schoolonderwijs, zich de hinderlijkste platheden in hunne volksspraak afleeren, en onder anderen de boerenkinderen reeds bijna spreken als in de steden. Iets echter blijft er nog altijd over, dat geboorte op het platte land verraadt. Eindelijk, geen welopgevoed burgerman zal ooit van pujen ['frogs', GR], guus ['children', GR] en dergelijke spreken. De onderdrukking der $h$ is nog veel in zwang, maar de bespottelijke bijvoeging, waar zij niet behoort, geschiedt alleen door het laagste gemeen, en dan nog veelal in oploopendheid en dronkenschap

(Sifflé 1835: 173-174) 
In general, one should not forget that the people from Zeeland have unlearnt the most cumbersome vulgarities of their vernacular language, particularly after the improvements in school teaching, and farmers' children, among others, already talk almost as they do in the cities. Something, however, always remains that reveals a country birth. At last, no well-bred citizen will ever use pujen 'frogs', guus 'children' and the like. The suppression of $h$ is still quite common, but its ludicrous addition where it does not belong only occurs among the lowest common people, and even then in a state of rage and/or drunkenness.

The vehement discourse against regional forms indicates the archival value of regional lexical items: the idioticons served as archives of a language that was soon to die out.

In the same period when Arie de Jager started the Taalkundig Magazijn, the well-known southern Dutch author and language commentator, Jan Frans Willems (Weijermars 2018) began his journal Belgisch Museum ('Belgian museum'). In the first volume, he introduced a series called Proeven van Belgisch-Nederduitsche dialecten ('Examples of Belgian-Dutch dialects', cf. Belgisch Museum 1837: 33-37), in which he aimed to present the Parable of the Prodigal Son (Luke 15: 11-32) in various southern dialects. A similar project had been undertaken by Franz Mone, a German of Dutch descent, just one year earlier (1836) in his periodical, called the Anzeiger für die Kunde der deutschen Vorzeit. ${ }^{3}$

The introduction to the series shows that Willems was primarily interested in collecting materials for southern Dutch idioticons, but he also took great care to render local phonology as veraciously as possible by defining an orthographical reference system and by providing phonetic explanations in footnotes. Over the next ten years, many dialect versions of the Parable were published, sometimes signed by Willems' informants, in later years also from northern Dutch places such Rotterdam and Utrecht. ${ }^{4}$ The phonetic explanations soon disappeared, and

3. Mertens (2010: 47-49). Already in 1806-1807, the French central government, particularly the Bureau de Statistique, sent questionnaires to the southern Dutch departments that were part of the French empire, inquiring about language choice as well as the specific forms of the local language that were in use (Bakker \& Kruijsen 2007: 13). The form of the language was to be recorded by rendering the Parable of the Prodigal Son in the local dialect. Bakker \& Kruijsen (2007) edited and discussed newly discovered examples from Limburg and the neighbouring Rhineland areas.

4. Volume 1 of the Belgisch Museum has Brussels, Ghent, Antwerp and Louvain (1837: 37-39, 206-208, 284-286, 408-409), volume 2 has Bruges, Kessel (near Venlo), Beveren and Courtrai (1838: 54-56, 172-173, 328-329, 424-426), volume 3 Geeraardsbergen, Maastricht, Roeselare and the Meierij of 's Hertogenbosch (1839: 94-96, 194-196, 383-386, 387-391), volume 4 comprises Ninove, Poperinge, Eeklo and Lier (1840: 97-99, 154-155, 249-250, 389-390), volume 5 Mechelen (1841: 57-59), volume 6 Rotterdam (1842: 325-326), volume 7 Utrecht 
the series thus developed into a portrait gallery of local dialects. While the series suggests a more favourable attitude towards local varieties than, for example, Sifflés, a scholarly approach remained absent. The Belgisch Museum also occasionally comprised texts fully in line with the folklorising and depreciatory approach outlined above. Lambin, for example, discussed the straettael 'street language' of Ypres, which he characterised as bedorven 'rotten' and emanating from eene gebrekkige uitspraek 'a deficient pronunciation' (1837: 396).

But different voices could be heard, already in the first half of the century. Halbertsma (1836) published a lexicon of the language of Overijssel in the north east of the language area, aiming to contribute to the lexical inventories of regional varieties created in the context of a national dictionary (see Chapter 7 and Section 9.2.2). While traditional in that respect, Halbertsma held a polemically positive view of dialects, waarop eene verouderde minachting drukt 'which suffer from an oudated contempt'. It seems significant that he referred to dialects as taal 'language', implying that dialects should be analysed as linguistic systems in themselves. Halbertsma was of Frisian descent, and was in fact a key figure in the Frisian emancipatory movement and an activist for the Frisian language, which he considered to be a separate Germanic language, as opposed to the then common idea that Frisian was a Dutch dialect. He also created a Frisian standard spelling (see also de Jong 2009 and Feitsma 2012).

Another deviant voice was J. H. Behrns (1840), who published a study on the historical phonology of the dialect of the Twente region in the north east of the language area. Behrns stressed that the study of dialects would enhance the knowledge of language in general, and continued:

Dit althans is het gevoelen der kundigste mannen van onzen tijd, die de taalbeoefening niet meer willen bestaan hebben in de nasporing van één enkel bevoorregt dialect, tot schrijftaal verheven, en in de kunstmatige ontwikkeling van grammaticale regels, daarvoor passende; maar veeleer in het historisch onderzoek van de geheele volkstaal, zoo als zij zich in de schriftelijke overblijfsels van alle tijden en in den mond van het gansche levende geslacht vertoont

(Behrns 1840: 334) In any case, this is the conviction of the most learned men of our time, who no longer want the study of language to consist of merely the investigation of one privileged dialect, which has been elevated to the writing language, and the artificial development of appropriate grammatical rules; rather, they want to investigate historically the whole language of the people as it manifests itself in the written traces of all times and in the mouths of the entire living race.

(1843: 266-268), volume 8 Diest and Sint-Truiden (1844: 14-16, 261-263), volume 9 Ypres (1845: 213-215), and volume 10 Oudenaarde (1846: 239-240). 
Behrns (1840: 334) signaled that some would consider his study of the Twente dialect to be belachelijk 'ridiculous', but he sided with "the most learned men of our time" mentioned in the quotation, with which he referred to Grimm, Rask and other representatives of the new historical-comparative paradigm (Behrns 1840: 331-332). His study offers a thorough description of the vowels and consonants of the Twente dialect in a Germanic perspective, including comparisons with Old High German, Old English, Gothic and Icelandic.

Dutch dialectology as an autonomous and established academic discipline came into existence in the second half of the century, particularly in the final quarter of the period (Gerritsen 2001; Goossens \& Van Keymeulen 2006). An important contribution was Winkler (1874), a collection of northern and southern Dutch dialect translations of the Parable of the Prodigal Son. While there was a solid tradition of idioticons by that time, dialect lexicography on the other hand only developed into a more scholarly activity by the end of the century (Goossens \& Van Keymeulen 2006: 74-80).

\subsection{Final remarks}

Folklorisation is an auto-exoticist process that decontextualises and objectifies elements different from a normalised centre, after which the folklorised elements are placed in a subordinate position within the nation as a whole (Rogers 1999: 72). Linguistic folklorisation affects the non-standard forms within standard language ideology, constructing these as exotic, non-neutral, and deviant. The folklorising approach to regional variation was exemplified by the embracing of lexical variation in the compilation of idioticons - a highly revealing term from an exoticist perspective. The approach was also demonstrated by the enregisterment of deviant language forms. In some cases, folklorisation inspired authors to argue for the erasure of non-standardness. The eighteenth-century folklorising approach was continued into the nineteenth century, when, however, the ongoing interest in regional languages also gave rise to different, perhaps less prejudiced takes on the matter of regional variability, particularly from around 1840. In the same period, the use of dialect as a literary and performance strategy developed, for example within the newly founded carnival clubs such as Momus in the city of Maastricht, and Jocus in Venlo (Kessels-van der Heijde 2015: 178). In the second half of the century, dialectology came into existence as an autonomous discipline.

These developments are fully inscribed in the discursive construction of the linguistic situation as diglossic instead of diaglossic (Chapter 3). The discursive split into standard and non-standard led to standard forms as possible objects of linguistic analysis (Chapter 8). Non-standard forms gradually became objects of 
study, too, though sharply distinguished from standard language linguistics. The separation of standard language linguistics and dialectology would strongly influence future developments in the language sciences, even until the present day (see also Armstrong \& Mackenzie 2013). Note, however, how Sifflés (1835) brief description of the situation in Zeeland, cited in 9.4 above, suggests a continuum of localisable, traditional Zeeland dialects on the one hand, the Holland-based supralocal variety on the other hand, and a lot of individual variation and styleshifting in between. In fact, in the north of the language area, shifting to a Holland-based variety in urban contexts led to the rise of so-called Town Frisian as early as the sixteenth century (van Bree \& Versloot 2008). Similarly, Niebaum (2009: 7), analysing the Groningen-based play Et en Fret (1793, see 9.3.3), notes how some characters speak the city dialect of Groningen and some a Hollandic supralocal variety, while others use een soort 'halfdialect' 'a kind of half dialect'. Such evidence of diaglossic repertoires was however erased by the discursive compartmentalisation of the linguistic continuum into standard/dialect diglossia. 

PART IV

Perspectives from below 



\section{Policy and its implementation in education With Bob Schoemaker}

\subsection{Introduction}

In addition to selection, codification and elaboration of function, a crucial element of any theory of standardisation is implementation. In Haugen's (1966) classic analysis, acceptance was still the fourth key concept. While selection and codification concern the form of the language, elaboration of function and acceptance relate to its functions in society. At least some part of the language community should accept the standardised variety as the prime variety. Haugen (1972) replaced acceptance with propagation in order to have an active rather than a passive 'procedure', in line with the other three terms, and in accordance with his aim of not only describing past standardisations, but also of devising a model for future language planning activities. Another problem with acceptance is that it is an attitudinal concept, requiring researchers of past standardisations to look into the minds of historical players, while we also know that attitudes and behaviour do not necessarily correspond (e.g. already Trudgill 1972).

Haugen (1987: 59-64) re-evaluated his model and adopted implementation as the fourth term, beside selection of norm, codification of norm and elaboration. He defined implementation as "the activity of a writer, an institution, or a government in adopting and attempting to spread the language form that has been selected and codified", thereby stressing that "the spread of schooling to entire populations in modern times has made the implementation of norms a major educational issue" (Haugen 1987: 61). Here, implementation touches upon acquisition planning (Cooper 1989; Hornberger 2006), that is the often governmental efforts at spreading the standard variety among speakers, in the context of European nationalism particularly through the school system as " $\mathrm{t}]$ his was the institution where the ideology of one people, one territory and one language could be translated into reality" (Wright 2012: 71).

In this chapter and the next, a perspective 'from below' will be taken in order to investigate the implementation of the Dutch national variety in the period immediately following its official codification in 1804 and 1805. First, the contribution of the field of education to the spread of the national variety will be investigated, 
focusing on teaching practices by individual schoolteachers in various regions of the Dutch state. Another aspect of implementation concerns the spread of the newly codified variety in actual language use. In Chapter 11, the question of whether writers switched to the officially prescribed variants will be investigated through corpus-based analyses of language use, without making any assumptions about acceptance as an attitudinal phenomenon.

There are many different ways in which a focused, supralocal variety can spread through a language community. Whereas classical analyses of standardisation in the spirit of Haugen (1966) have often concentrated on top-down processes, stressing the importance of explicit norm selection and codification, it has also been argued that bottom-up developments of accommodation and norm convergence in spoken and written language use may be equally - if not more - relevant to theories of standardisation (e.g. Elspaß 2014; Rutten 2016b and the references there). In the specific situation analysed in this study, the northern Low Countries in the late eighteenth and early nineteenth century, standardisation was heavily politicised. This informed an explicit top-down policy aimed at the dissemination of the national language across the population. The societal domain of education was supposed to be instrumental in this. Completely in line with the educational focus of Dutch Enlightenment discourse (Section 2.4; see also below, 10.2), the burden of spreading the standard lay with schoolteachers and school inspectors.

Many different actors and domains are usually taken into account in discussions of standardisation, including printers, political, cultural and intellectual elites, the administrative domain, the media and so on (Deumert \& Vandenbussche 2003; Vandenbussche 2007). Education is also always mentioned as a crucial domain, facilitating the transmission of the standard from one generation to the next. However, as stressed by Vandenbussche (2007: 29), hardly anything is known about actual teaching practices. Whereas official policy documentation and schoolbooks can be explored to reconstruct educational policies and teaching methods, what actually happened in historical classroom interactions remains largely invisible.

This chapter focuses on the role of schoolteachers and school materials in the national language-in-education policy. It aims to answer a number of questions: to what extent was the official policy implemented in actual teaching practices? Did schoolteachers adhere to standard language ideology (SLI), and did they design teaching practices in accordance with this ideology? To what extent did the new school system that came into being in this period contribute to the dissemination of the national language? How were the new language norms transmitted to younger generations?

The decades around 1800 not only saw the nationalisation of language in metadiscourse and subsequently in the official codification of Dutch, the field of education was equally subject to debate as well as to efforts at nationalisation. Section 10.2 
focuses on major changes in the educational system, particularly with respect to language in education. In Section 10.3, we discuss the place of language norms and of localisable variants in the national school system. Section 10.4 focuses on the implementation of language norms in teaching materials.

\subsection{Educational policy: Major changes}

Section 10.2.1 first provides a brief overview of education in the eighteenth century. Particularly in the second half of the century, an Enlightenment discourse of change developed that targeted the field of education (10.2.2). Towards the end of the century and in the early nineteenth century, many decades of educational discourse led to a series of changes in policy and practice (10.2.3).

\subsubsection{Education in the eighteenth century}

The Low Countries displayed a relatively dense network of schools, with many towns and villages having various types of schools already in the late medieval period (de Booy 1977: 9; Dekker 2006: 159). This situation continued into the Early Modern period. From the sixteenth century onwards, changes such as the steep development of trade and the concomitantly increasing use of merchant correspondence, the ongoing textualisation of society and the rise of bureaucracy, and the availability of inexpensive printed matter stimulated the need for education. At the same time, a vibrant metadiscourse about education came into existence.

In the seventeenth and eighteenth centuries, the northern Netherlands constituted the Republic of the Seven United Provinces, which had a federalistic political structure. Authority over the educational field, that is, over schools, curricula, schoolteachers, financial matters and so on, lay with regional, local and church authorities. The educational field was highly diverse with many different school types, more often than not separated from one another along social and gender lines. In addition, the nobility and the non-noble ruling classes adopted a practice of private education at home.

In terms of content, a broad division into three school types is usually made. The Nederduitse 'Dutch' school was a form of primary education offering reading, writing and arithmetic, in addition to what was generally considered to be the most important topic, viz. religious education. Reading and writing skills were taught successively. Since many children left school early, this implies that more people were able to read than to write. The French school and the Latin school were forms of secondary education, preparing pupils either for trade or for university. At French schools, bookkeeping and foreign languages such as French, English and 
German were often taught, particularly in the eighteenth century. Latin schools taught mainly Latin and Greek. The social reach of these two types remained fairly limited, with only 3 to 5 per cent of the population attending a French school in around 1800, and only 1 per cent attending a Latin school (Frijhoff 1983: 22).

Reading education at Dutch schools in the eighteenth century consisted of three parts: the alphabet, spelling and reading itself. For the first two parts, so-called abc-boekjes 'abc booklets' were mostly used offering the alphabet in Roman script and in Gothic or Fraktur script, as well as often in Italic (cursivo) script and in cursive handwriting - and in all cases, both the majuscules and the minuscules were taught. After having learnt the letters of the alphabet separately, pupils would move on to combine letters to form sets of two letters - not necessarily existing syllables of Dutch - and from there on to spell and read syllables and simple words. This was often practised with religious examples such as prayers and the Ten Commandments. Such enduring attention being paid to spelling was common practice, and would develop into one of the major issues in eighteenth-century educational discourse.

When spelling and basic reading skills had been acquired, a common next step was the use of still relatively easy books such as the Trap der Jeugd ('Stairway of the young'). These typically also included chapters about religious, arithmetical and geographical topics. Occasionally, such booklets also comprised short discussions of a limited number of grammatical phenomena, for example the parts of speech. Reading was additionally practised with more extensive reading materials such as the Heidelberg catechism and widespread printed matter such as the Historie van David ('History of David'), the Spreuken van Salomo ('Proverbs of Solomon'), and newspapers.

Writing education at Dutch schools primarily focused on the technical ability to form letters manually, usually through copying handwritten examples. This focus on so-called mechanical writing and on the ability to produce neat letters is a well-known phenomenon across Early and Late Modern Europe (Fairman 2007a; Elspaß 2007: 154).

\subsubsection{A discourse of change}

As argued in Section 2.4, language and education became objects of political control in the northern Low Countries in the decades around 1800. The educational system was seen as a powerful means to homogenise the population, and language was deemed to play a crucial role in the homogenisation process. Thus, the establishment of a national political unity was accompanied by the rise of standard language ideology.

In the Enlightenment debates on educational reform, which largely took place within the many private and semi-public societies, language was discussed in 
terms of the necessity of 'mother tongue' education (see Section 6.5.1). While the concept of Moedertaal 'mother tongue' was usually not explained, part of it was probably constituted by the in itself not invariable supralocal writing tradition and by the eighteenth-century grammatical tradition. Obviously, the same traditions had also been part, at least to some extent, of the preceding decades of mother-tongue education.

In some respects, it is hard to judge the eighteenth-century educational system, not only because of the temporal distance, but also because it has been strongly criticised from the late eighteenth century onwards. Moreover, it is a general characteristic of the Dutch Enlightenment that the optimism connected with much Enlightenment thought was accompanied by a strong discourse of decay (van Sas 2004: 73). This also applies to educational discourse. According to Los (2005), Dutch educational discourse of the Enlightenment should be seen as a form of cultural criticism. While there is some evidence that economic decline led to insufficient maintenance of school buildings and to the deferred payment of schoolteachers, this discourse is characterised by a combination of extreme criticism of the existing situation, and a hopeful call to redesign the whole educational system. Nonetheless, pedagogics did not yet exist as a separate field of research, there were no teacher training institutes, and, in general, teachers were poor and not very well educated. This certainly means that the educational system was in many respects less well organised than in more recent periods.

This lack of organisation and the assumed lack of competence among schoolteachers were severely criticised in eighteenth-century educational discourse. In the second half of the eighteenth century, a lively educational debate developed, particularly within learned societies based in Holland and Zeeland (Section 6.5.1). A commentator such as Krom (1782: 17), for example, complained that teachers' exams, when they were held, tested the teachers' aptitude for religious services in terms of reading out loud and singing, rather than their knowledge of language and arithmetic, and their pedagogical competence. The teaching profession had a relatively low social status, and anything other than citing the catechism by heart, singing psalms, and caligraphic writing was not to be expected from the typical eighteenth-century schoolteacher (Krom 1782: 12). The new educational discourse was partly inspired by the pedagogical ideals developed in the slipstream of Locke and Rousseau (Lenders 1988; Los 2005; Dekker 2006). These new ideals included, among others, child-friendliness, an emphasis on virtue instead of on religion, a preference for clear language, and the aim of relating teaching contents to the everyday experiences of the child.

Criticism of contemporary reading education related to such aspects as children's leestoon 'reading tone': pupils read too monotonously, or too melodiously, or too softly, or too loudly, and so on. The criticism was often extended to the teachers, who also read in the same manner, as well as to the teaching methods, such as the 
aforementioned extreme focus on spelling exercises (Schoemaker 2018). In many cases, reading exercises consisted of repetition tasks. However, repeating what the teacher had previously read out was at least as much a memory task as a reading task. In the same vein, the presumed lack of understanding of what was read was criticised. According to the proponents of educational reform, technical reading prevailed over reading comprehension - a situation that they deplored. At the same time, literacy rates went up considerably from the seventeenth to the eighteenth century, with the majority of both women and men being able to read by around 1800 (Kloek \& Mijnhardt 2001: 18).

Irrespective of the merits, or lack thereof, of eighteenth-century schools, the combination of a discourse of decay, the call for reform, and the nationalist enterprise of creating homogeneity through language and education led to a series of actual reforms in the early 1800 s.

\subsubsection{Changes in educational policy}

In the same period as the official spelling (Siegenbeek 1804a) and grammar (Weiland 1805a) were published on behalf of the national government, the 'agency for national education', that is, the Ministry of Education also worked on a series of educational reforms, resulting in the school acts of 1801, 1803 and 1806 (see also Section 2.5). While the success of the various school acts has been the topic of historical debate, there are quite a few concrete results to be mentioned. In addition to the official regulations promoted by the national government, various private initiatives also led to significant changes in the educational domain.

The first school act of 1801 established a national system of school inspection. The Dutch Republic was subdivided into 8 departments and 35 districts. The 35 school inspectors of the individual districts made up the departmental boards, which were under direct control of the ministry of education in The Hague. The implementation of new educational regulations was to a large extent the responsibility of the school inspectors, who had to negotiate with local, regional and church authorities about the reorganisation of the schools, and who had to ensure that new ideas and methods found their way into concrete teaching practices.

Another important result of the school act of 1801 was the establishment of an educational periodical issued by and under the responsibility of the Ministry of Education. The Bijdragen betrekkelijk den staat en verbetering van het schoolwezen ('Contributions concerning the state and improvement of the educational system') published all official documentation about the school system as well as news about specific schools, job advertisements, book reviews and articles about pedagogical, educational and professional topics. The Bijdragen would be the main medium for educational information and discussion well into the nineteenth century. 
The effort at nationalisation of the first school act met with quite some federalist opposition, particularly from the local, regional and church authorities who had controlled local schools for centuries, but also from schoolteachers and parents who preferred to maintain the existing situation. When the official response through the school act of 1803 turned out to be an even stronger nationalisation of the system by a general abolition of all traditional, non-national regulations, the opposition increased, and in many places, the school act was simply not complied with.

After the 'agency for national education' had been discontinued, and the field of education had become part of internal affairs, senior official Adriaan van den Ende (1768-1846) was charged with designing a new educational act. In 1803, van den Ende had already been responsible for the Handboek voor de onderwijzers op de lagere scholen ('Handbook for teachers at primary schools'), which comprised an overview of the most important pedagogical ideas of the time. The school act of 1806, designed by van den Ende, was less radical than the previous school act, particularly in terms of coercion. Van den Ende acknowledged the resistance of local authorities, parents and teachers against radical changes, and again relegated the responsibility for the implementation of many policy proposals to the individual school inspectors. In addition, the old distinction between public and private schools, which the act of 1803 had aimed to terminate, was restored. Whereas private schools formally also fell under the national law, they were granted considerable freedom, and inspectors would generally focus on public schools. It is estimated that around twenty per cent of the population was in private schools in the first half of the nineteenth century (Knippenberg 1986: 87). The quality of private schools, however, was generally not higher than that of public schools, which was partly due to the fact that private schools were often more conservative and clung to old teaching practices.

Importantly, the school act of 1806, which would determine the organisation of the educational system for the next fifty years, explicitly mentioned language as one of the core elements of the national curriculum. It identified reading, writing, arithmetic and linguistic knowledge as the "initial principles of knowledge and culture" (cf. Schoemaker 2018). Previously, religious education was the fourth term accompanying reading, writing and arithmetic. The act did not provide detailed regulations for the implementation of these core elements in educational practices. As before, the school inspectors were responsible for this. In order to further the knowledge of the new orthography, copies of Siegenbeek (1804a) were sent to all schools.

The school act of 1806 introduced a new system for teachers' exams. Four different levels of competence were introduced with varying requirements regarding metalinguistic expertise. The regulations were not very specific (Schoemaker 2018), but it seems plausible that higher-level teachers were expected to familiarise themselves 
with the rules of orthography and the parts of speech. A didactic novelty introduced by the school act of 1806 was frontal teaching (klassikaal onderwijs), which was to replace the former practice of individual teaching (hoofdelijk onderwijs).

The act of 1806 also announced the long-awaited national booklist. A crucial issue in many traditional schoolbooks was their too prominently present Protestant character, while the educational reforms of the late eighteenth and early nineteenth century advocated a general Christian identity, in line with the prevalent inclusive ideology. It should be noted that this inclusive ideology did not imply that the large Catholic and Jewish minorities were satisfied with the organisation of the educational field. Quite the contrary, in the course of the nineteenth century, different religious and political identities would dominate educational discussions, resulting in the first official recognition of freedom of education in 1848. Van den Ende also co-authored the Algemeene boekenlijst ter dienste van de lagere scholen ('General booklist for the benefit of primary schools'), first published in the Bijdragen in 1810. Apart from the aforementioned religious issue, another important impetus to this list was the need for schoolbooks conforming to the new pedagogical ideas as well as to the officialised national language.

The school acts of the early nineteenth century did not yet lead to compulsory education. In the northern Netherlands, primary education only became compulsory in 1900. As mentioned before, a relatively dense network of schools had existed since late medieval times. While school attendance depended on child labour, and fluctuated with the seasons, it is estimated that in the first half of the nineteenth century between 50 and 80 per cent of the child population attended primary school, with some regional differences and a gradual general increase over time (Knippenberg 1986: 118).

Teacher-training colleges were founded from the 1790s onwards, and were the result of private initiatives, particularly of members of the Maatschappij tot Nut van 't Algemeen 'Society for Public Advancement' (see Section 4.4). In 1796, training colleges opened in Amsterdam and Haarlem. In the following years, many other cities would follow, such as Groningen (1797), Leiden (1800), Rotterdam (1801), The Hague (1804), Delft (1806), Utrecht (1808) and Dordrecht (c. 1811). In addition, some active schoolteachers offered teacher-training programmes in the evening (Schoemaker 2018). Political and economic disturbances, along with a limited interest by prospective teachers, soon led to the termination of many of these initiatives. In 1816, the government decided to establish the first rijkskweekschool 'national training college' in Haarlem.

Another important development was the establishment of teachers' societies. Private initiative was again crucial. The aforementioned educational periodical Bijdragen (1801-II: 97-102) called for such initiatives. In 1803, school inspector W. Goede published an article in the Bijdragen, in which he referred to the 
aanzoek van deze en gene Onderwijzers der Jeugd, om hen het noodig onderrigt in de gronden der Nederduitsche taal te willen toedienen; en ik kon zulks des te minder afslaan, naardien ik, eenigen tijd te voren, hoe wel vruchtloos, mij tot het geven van lessen daar in, openlijk aangeboden had in de Rotterdamsche Courant

(Bijdragen 1803-IX: 43)

proposal of some teachers of the young to provide them with the necessary education in the foundations of the Dutch language; and I could certainly not refuse this, as I had offered such lessons in the Rotterdamsche Courant some time before.

At their meetings, the schoolteachers discussed the orthographical and grammatical treatise published by Weiland in volume I of his dictionary (see Section 7.4; Weiland 1799), which Goede expected would soon be officialised.

In the first period of the nineteenth century, similar teachers' societies were founded in many places. Often, school inspectors played an important role in this. As with the private training colleges, the political upheavals of the period disfavoured the continuation of the teachers' societies. This inspired the government to offer some financial support from 1815 onwards. As of then, the periodical Bijdragen was sent to the societies free of charge.

\subsection{Language norms and language use in the national school system}

As explained above, the educational reforms of the early 1800s led to the establishment of a national school inspection system as an important control mechanism. The school inspection system generated substantial archival sources, and in this section, we discuss school inspection reports from the first half of the nineteenth century. In particular, we want to find out whether school inspectors and teachers actively promoted the officially codified variety of the language (Siegenbeek 1804a; Weiland 1805a), and to what extent this implied discouragement of the use of other varieties of Dutch. Was standard language ideology part of everyday teaching practices and of the professional activities of school inspectors? In order to answer this question, we focus on the transmission of language norms in Section 10.3.2. In Section 10.3.3, we focus on actual language use in the classroom, specifically on the ways in which non-standard language was policed. It is important to keep in mind that the actual implementation of the language-in-education policy was the responsibility of the individual school inspectors. This means that school inspection reports may offer a unique bottom-up insight into the implementation stage of the official top-down language standardisation that was happening at the same time. 


\subsubsection{The school inspection system}

A body of 35 school inspectors ensured the implementation of the school acts and the reform of the school system. They monitored the quality of education and provided feedback to teachers and policymakers. School inspectors were mainly recruited from people who had been active in educational reforms, for example as advocates of the new school acts or as pedagogues in favour of new teaching methods. They represented a wide range of professions including teachers, clergymen and politicians, and they generally belonged to the upper and upper-middle ranks in which the movement for school reform was rooted (Schama 1970: 576).

The inspection system was organised on a departmental, that is provincial, level. Within the departments, each school inspector was responsible for his own school district. He would visit the schools in his district two to four times per year, indicating problems and issues in need of improvement in his inspection reports, which were subsequently discussed in the quarterly meetings of the departmental educational committees.

Comments on a single school range from a few lines to multiple pages. Complete reports comprising comments on all schools in a district range from five to sixty pages. Many of these handwritten reports are accessible today in regional archives throughout the Netherlands. In this section, we discuss 307 reports from the archives of North Holland, a region in the centre of the language area, and from the province of Groningen, a peripheral region in the northeast bordering on Germany. The reports stem from the establishment of the inspection system in 1801 until 1854, after which no reports are retained until the transformation of the inspection system in 1857. North Holland was the birthplace of school reforms, and home to the Maatschappij tot Nut van 't Algemeen 'Society for Public Advancement' and various influential pedagogues such as P. J. Prinsen and N. Anslijn. Groningen boasted the highest school attendance rates in the country. Due to influential teachers such as $\mathrm{H}$. Wester and Th. van Swinderen, it was also the leading province in implementing new teaching methods (Knippenberg 1986).

Following Langer (2011), we consider school inspection reports to be highly valuable sources in historical sociolinguistics. They provide information on topics such as teaching methods and materials, the skills and quality of teachers, school attendance, the use of schoolbooks, school buildings and legal and financial aspects of the school system. Contrary to the prescriptive nature of sources such as schoolbooks, pedagogical literature and official regulations, these reports provide descriptions of actual classroom practices. It should be noted, however, that given the varying professional backgrounds of school inspectors, different interests prevail in the reports. Some inspectors focus exclusively on matters of organisation and finance, while others focus more on issues of pedagogy and the content of 
education. Examining these reports, our focus was on all matters pertaining to language, linguistics and language-in-education.

\subsubsection{Transmission of language norms}

In the first half of the nineteenth century, pupils acquired active knowledge of language norms through advanced writing education, so-called grammatical writing (Fairman 2015), and through grammar as a distinct school subject. Grammatical writing consisted of the autonomous composition of sentences, letters and essays, in which children learned to "express their thoughts in writing" (Algemeene denkbeelden 1798). It was called grammatical, because it required the active application of rules of orthography, morphology and syntax. The inspection reports show us the kind of exercises teachers used and how pupils performed:

(1) Rijkens [de onderwijzer] dicteerde de leerlingen der hoogste klasse een stukje ten opschrift hebbende Nederland, het doel en de strekking van hetzelve was den leerlingen liefde voor en gehechtheid aan den vaderlandsche grond in te boezemen - Ik zag een vijftal van dezelve na, en ondervond, dat zij wat taal en spelling aanging volkomen zuiver waren, in slechts twee ontmoette ik ééne spelfout

(Van Cleeft, April 1832, 889: 47 [GA])

The teacher Rijkens dictated to the pupils of the highest grade an excerpt titled the Netherlands, its goal of which was to inspire in the pupils love for and dedication to the fatherland - I looked over five of them and found, that they were pure in regard to language and spelling, in only two I found one spelling mistake.

(2) bij het vergelijken der maandelijksche schriften bleek het dat de vorderingen zeer aanmerkelijk waren. - het vervoegen en verbuigen was zeer goed - bijzonder gevielen mij zeer de opstellen der kinderen over een opgegeven woord B. V. Bijbel - Maanlicht \&c. en ik vond daaronder verscheiden volzinnen die mij en van de vorderingen in de Holl. taal en van de verstandsontwikkeling der kinderen zeer gunstige begrippen gaven

(Rutgers, July 1818, 889: 40 [GA])

in comparing the monthly writing exercises it became apparent that the progress was remarkable. - conjugation and declension were very good - the essays of the children on a given word, e.g. Bible - Moonlight, etc. pleased me in particular and I found in them several sentences that showed great progress in the Dutch language and in the intellectual development of the children.

Grammatical writing was contrasted with mechanical writing, that is the technical skill of writing letters and words. Until the nineteenth century, the emphasis in writing education was on mechanical writing. The quality of handwriting was a 
marker of status, and likewise the quality of a school was measured by the teacher's handwriting (van Gestel \& van der Laan 1915). Knowledge of language norms was no prerequisite for good writing. Teaching consisted of copying handwritten examples such as religious maxims and prayers. In the early nineteenth century, following the rise of the uniform national standard, the focus shifted to grammatical writing. The quality of handwriting, however, remained an important criterion for good writing education.

Grammar as a separate subject was, until the nineteenth century, limited to secondary education, specifically to so-called French and Latin schools. Since only $5-6 \%$ of the population attended such schools, and since knowledge of the national language was deemed important to every citizen, the school acts of 1801-1806 listed grammar as a compulsory subject in primary schools (Frijhoff 1983: 23; Van Hoorn 1907: 224). It consisted of identifying the parts of speech, declension and conjugation, and from the 1820s onwards, sentence analysis. Again the reports show us how grammar was taught. A common exercise was the correction of erroneous sentences:

(3) Aan [de leerlingen] gaf ik eene [...] uitvoerige en moeilijke proeve op, welke laatste bestond in eenige voor de vuist geschreven regelen, waarin men bijkans geen woord vond, of den regelen eener goede Spelkunst waren daarin verwaarloosd, en wel vooral was ik bedacht geweest, om verkeerde en moeilijke verbuigingen en vervoegingen erin te vervlechten [...]. Ik liet dit stuk door alle de leerlingen $[\ldots]$ verbeteren, [...] met dien uitslag, dat er in het einde slechts twee fouten overbleven. Als eene bijzonderheid ontdekte ik, dat er onder die leerlingen waren, die met de Spelling van den Hoogleraar Siegenbeek niet geheel onbekend waren

(Beets, 1806, 89: 27, [NHA])

I gave [the pupils] a lengthy and difficult exercise, which consisted of some randomly written lines, in which almost no word could be found in which the rules of proper spelling were not neglected, and above all I had made sure to add erroneous and difficult declensions and conjugations [...] I had all pupils correct this excerpt $[\ldots]$ with the result that in the end only two mistakes remained. In particular, I found that there were among those pupils some who were not unfamiliar with the spelling of Professor Siegenbeek.

(4) Op het bord [ter verbetering] stond: de os is een groot dier als hij geslacht is, lus ik hem wel, inplaats van lust ik hem wel, en op een ander bord stond: welke weg moet ik nemen naar Delfzijl, inplaats van welken weg

(van Swinderen, 1824, 889: 43 [GA]) On the blackboard was written: the ox is a large animal when he is slaughtered, [lus ik hem wel] I like him, instead of [lust ik hem wel] I like him, and on another blackboard was written: [welke weg] which road should I take to Delfzijl, instead of [welken weg] which road. 


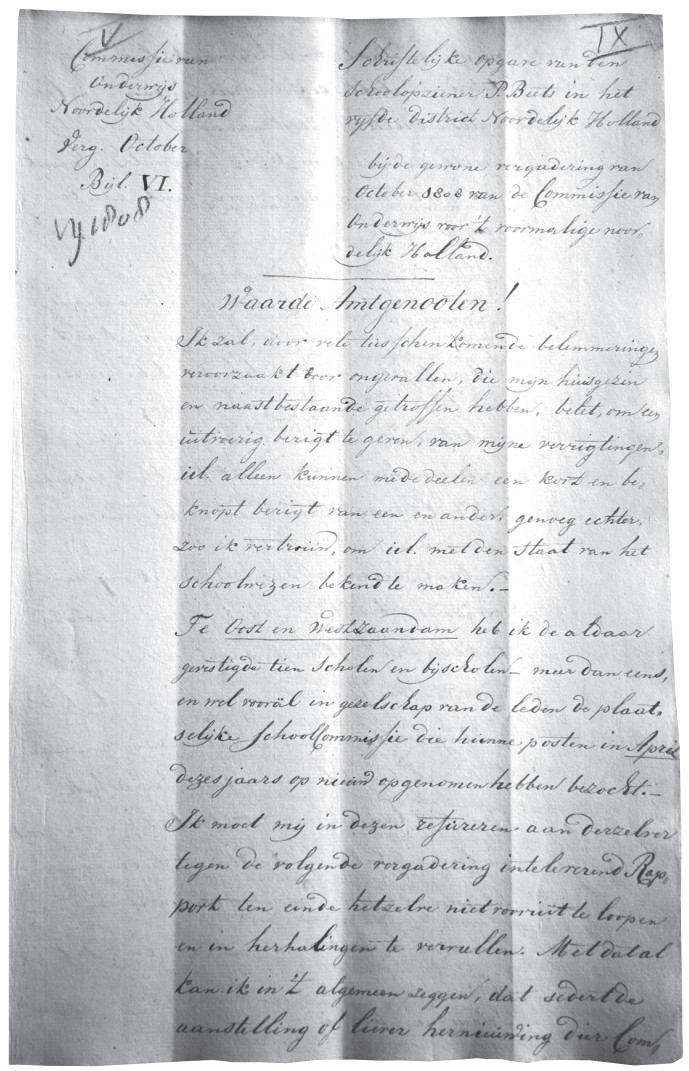

Figure 1. Report by school inspector Beets (October 1808, 89/41, NHA)

(5) Een opstel op het bord van dezen inhoud. 'God lied adam wonen in dal paradies een groot en schoone woning in het hertogdom luxemburg, het ligt digt bij de revieren de wolga $\&$ de loire' werd zeer goed ontleed en verbeterd

(Bouwers, April 1822, 889: 42 [GA]) $)^{1}$ An essay on the blackboard with this content: 'God let adam live in valley paradise a big and clean house in the duchy Luxembourg, it lies close to the rivers the wolga \& the loire' was analysed and corrected very well.

Direct references to concrete language norms as in (4) are relatively rare in the reports. The same applies to references to the Siegenbeek spelling (1804a) and the Weiland grammar (1805a; Example (3)). Usually, school inspectors wrote about

1. The Dutch sentence is full of mistakes in capitalization, punctuation, orthography, declension etc. 


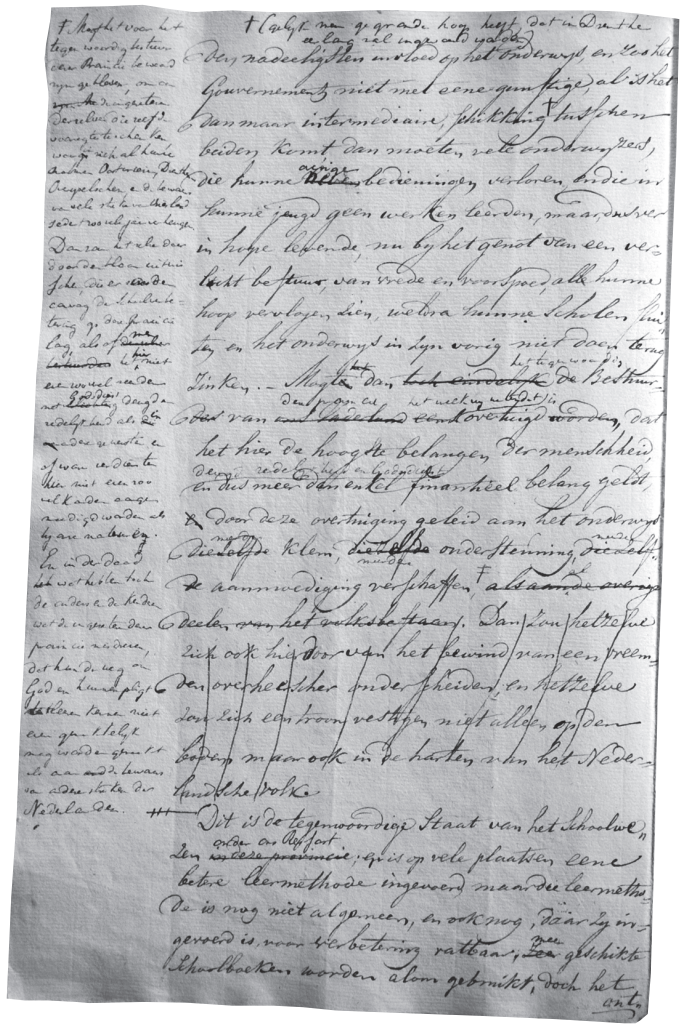

Figure 2. Report by school inspector van Swinderen (April 1814, 888/10, GA)

language norms in general terms, that is in terms of 'good' or 'pure' or 'uncivilised' language as in (1). Although it is plausible that such general comments did refer to Siegenbeek and Weiland, this was not necessarily the case. Particularly in the early decades of the nineteenth century, knowledge of Siegenbeek's orthography and Weiland's grammar was not ubiquitous. As we will argue in the next section, there were school inspectors who did not adhere to the strict uniformity implied by standard language ideology, and who were tolerant of more variable normative practices.

The school inspection reports give us a detailed account of language norm transmission. They provide an insight into methods, materials, exercises and performance in everyday classroom situations. But important insights can also be gained by looking at what is absent from the reports. In his study of school inspection reports from nineteenth-century Schleswig-Holstein, Langer (2011: 180) observes that "[i]n relation to the sheer size of the corpus, the number of references 
to linguistic matters is small [...]. This is surprising given the ever-present tension between the use of High German in schools and Low German in everyday rural life". A similar observation can be made with respect to the Dutch reports. Despite the importance attributed to the national language in educational discourse, and despite the publication of the official regulations by Siegenbeek (1804a) and Weiland (1805a), the number of references to language teaching and norm transmission is relatively low. This can partly be explained by the fact that some school inspectors reported exclusively on organisational and financial matters. Others, however, did report on the contents of education, but even so hardly any references to language norms are found in their reports. The reason for this is that in many schools in this period, the amount of time spent on grammatical writing and grammar was low. This, in turn, was due to a number of factors.

Before the school acts of 1801, 1803 and 1806, neither grammatical writing nor grammar were part of the primary school curriculum. In writing education, mechanical aspects of writing prevailed, such as writing posture, pen handling and fine writing. Grammar was limited to secondary schools. This changed at the turn of the century, when educational discourse stressed the importance of writing skills and knowledge of the national language, and both grammatical writing and grammar were added to the curriculum. However, due to limited financial means and opposition to reform, the implementation of the new curriculum was a slow and gradual process. The first half of the nineteenth century was a transitional period, in which old and new teaching practices coexisted (Boekholt 1978: 374). Both teachers and school inspectors had to get used to new methods of teaching. This explains why some school inspectors, who reported quite extensively on writing education, did so exclusively in technical terms, viz. in terms of writing posture, the quality of pen and ink, and the quality of handwriting.

Successive teaching was another old and continued practice limiting the time available for grammatical writing. Traditionally, reading and writing were taught successively, as young children were deemed unfit for the fine art of handling quill and (costly) ink and paper. In practice, writing education did not start until the age of 8-9 (de Booy 1977: 41). But in the late eighteenth and early nineteenth century, the school attendance was on average between the age of 5 and 10, after which most children, except those from higher social backgrounds, joined the labour force (de Booy 1977: 41). This means that most children spent only a year or two in writing education, and did not progress beyond basic mechanical copying exercises.

In the new curriculum, reading, writing and grammar were, ideally, taught simultaneously from an early age. The introduction of slates for writing aided this process, yet the late start of writing education was still common practice in many schools in the first decades of the nineteenth century (Davies 2005; Verhoeven 1994: 152). 
The absence of references to language norm transmission in school inspection reports shows that this was no self-evident part of school programmes in the first half of the nineteenth century, and that educational practices in many schools differed considerably from what we might expect based on official discourses and documents. At the same time, the reports show how schools that did teach grammatical writing and grammar integrated the teaching of language norms into exercises and other classroom practices. In both cases, the value of inspection reports for historical sociolinguistic research is attested.

\subsubsection{Language use in the classroom}

Apart from commenting on language norm transmission, some inspectors also reflected on the language that was used in the classroom by teachers and pupils. We should recall that some commentators had argued vehemently against the use of non-standard language in general, that is, not just in school situations but also at home (Section 6.5.2). Less strong versions of the newly developed SLI still relied on the interdependence of the two homogeneous categories of language and nation (Section 2.3). Against the background of this ideology, we expect policing practices to be omnipresent, specifically with respect to non-standard variants in the spoken language.

Again, metalinguistic comments prove to be relatively rare and seemingly random. This tells us something about the way in which school inspectors perceived language and about their attitudes to variation. Contrary to language norm transmission, policing language use was not part of the official language-in-education policy. Although the acquisition of so-called civilised speech was, in educational discourse, believed to be an important aspect of child development, this was not made explicit in curricula. There was no distinct subject nor were there separate methods or materials aimed at the acquisition of a spoken standard. For those who adhered to standard language ideology, of course, it was an implicit goal underpinning all educational activities.

The most common way for school inspectors to discuss language use is through the stigmatisation of dialect. The standard language was seen as the proper, civilised variety, while non-standard varieties were considered to be incorrect and uncivilised. We see this reflected in the reports:

(6) De tweede en hoogste klasse leest vrij wel en wordt tamelijk wel ondervraagd; jammer dat de beschaving eenigzins lijdt door de gewestelijke uitdrukkingen van $d o u, d y$, inplaats van gij en $\mathrm{u}$, wanneer de onderwijzer [...] met zijne schoolieren spreekt, het welk over 't algemeen ook wel wat vriendelijker behoorde te zijn

(Adriani, October 1821, 889: 42 [GA]) 
The second and highest grade reads well and is questioned well; unfortunately the civilisation [of speech] suffers slightly from dialectal expressions such as $[d o u, d y]$ you, instead of [gij en $\mathrm{u}$ ] you, every time the teacher $[\ldots]$ talks with his pupils, which in general could be more friendly.

(7) waar voorhenen geheel lomp Omlandsch gespeld en gelezen wierd, las men thans zuiver Hollandsch en algemeen (Van Eerde, June 1805, 888: 5 [GA]) Where spelling and reading were completely [Omlandsch] before, it is now pure and common [Hollandsch]. ${ }^{2}$

The idea that 'civilisation suffers' because of dialectal speech, or that there is a hierarchical opposition between 'boorish' and 'pure' types of spoken language, is characteristic of standard language ideology (see also Chapter 6). In some instances, school inspectors point out specific features that are typical of the regional language (cf. example (1) above):

(8) Het lezen en de uitspraak was vrij wel. De sch werd echter algemeen door sk uitgesproken (Van Goens, July 1837, 89: 117 NHA) Reading and pronunciation were pretty good. The sch however was generally pronounced as $\mathrm{sk}^{3}$

Despite the fact that the 'civilisation' of speech was not an explicit part of the curriculum, the reports show that teachers sometimes actively sought to suppress dialectal speech:

(9) Intusschen had de middelste klasse, onder toezigt van den tweeden ondermeester H. Barman ( 3 rang) een 50tal woorden (zonder onderscheid) beginnende met $\underline{\mathrm{h}}$ moeten opschrijven, 't geen in deze streken overal zeer doelmatig is, om de slechte uitspraak dier letter

(Stecher, April 1848, 889 [GA])

Meanwhile the middle grade, under the supervision of the second assistant teacher (...) had to write down some 50 words (without distinction) beginning with $\underline{h}$, which is especially suitable for these regions, because of the poor pronunciation of that letter. ${ }^{4}$

2. Omlandsch was the dialect of the province of Groningen. Hollandsch was often used to refer to the standard language.

3. In parts of North Holland, the /sk/ cluster is maintained to the present day, whereas many other varieties of Dutch including the standard variety have the fricativised variant /sX/ (De Wulf, Goossens \& Taeldeman 2005: maps 9-11).

4. Prevocalic /h/ is (or: used to be) deleted in parts of Groningen (Weijnen 1996: 248-249; De Wulf, Goossens \& Taeldeman 2005: map 214). 
(10) [Ik bemerkte] dat de kleine kinderen de grooten hinderlijk zijn en bij hun onderwijs de aandacht der grooten tot zich trekken. Vooral had dit plaats omdat de grootere kinderen hadden geleerd beschaafd te spreken, en de kleinen, dit nog niet geleerd hebbende, gaven telkens, wanneer zij zich in de Groningse tongval uitdrukten, aanleiding tot een luid gelach bij de grooten

(van Swinderen, October 1845, 889: 61 [GA])

[I noticed] that the younger children are troublesome to the older children and distract their attention in class. Above all this took place because the older children had learned to speak in a civilised way and the small ones, not having learned this yet, gave the older children reason for loud laughter every time they expressed themselves in the Groningen dialect.

(11) Toen ik de eerste maal in deze school kwam, en de kinderen met Omlander accent hoorde lezen, zeide ik tegen dezelve, dat zij het zoo niet moesten leezen: waarop hij [de meester] antwoordde, dat dit niet de schuld der kinderen maar de zijne was: dat hij in zijn dorp geboren en onderwezen was, en nooit zelf(s) anders geleerd, of kinderen onderwezen had, maar dat hij het zoude verbeteren: en waarlijk dat gebeurde ook, want na drie vier maanden terug komende, was de Ommelander uitspraak geheel verdwenen en had voor de Hollandsche plaats gemaakt

(van Eerde, July 1809, 888: 15 [GA])

When I came into this school for the first time, and heard the children read with [Omlander] accent, I told them, that they should not read like that. To which [the teacher] answered, that it wasn't the children's but his fault: that he was born and schooled in the village, and never learned or taught his pupils anything else, but that he would improve. And so it happened, because when I came back after four months, the [Omlander] accent had disappeared completely and was replaced by the [Hollandsche]

These comments follow a pattern that we expect based on standard language ideology: regional variants are stigmatised, dialectal speech is suppressed and the standard is promoted. It should be noted, however, that it was not always clear what the spoken standard variety was or should be. Contrary to the written standard, codified by the Siegenbeek (1804a) and Weiland (1805a), the spoken standard variety was by and large based on the language spoken by the 'civilised' elites in the province of Holland (see examples (7) and (11)). Knowledge of this variety had to be acquired through contact with standard speakers, in the absence of which teachers sometimes turned to the spelling for guidance. This often led to confusion and unnatural forms of speech: 
(12) Van Oosten zei, dat hij de tolmeester niet verstond, omdat die zoo Hollandsch sprak; maar Van Oosten gevoelt zeker niet, dat hij zelf ook wat gemaakt Hollandsch sprak, toen hij dit zeide. Hij moet zich hierin niet toegeven. Er is onderscheid tusschen beschaafd en gemaakt spreken. - Het eerste is te prijzen, het tweede te laken (van Swinderen, October 1836, 889: 52 [GA]) [The teacher] Van Oosten said that he couldn't understand the tax collector, because he spoke too [Hollandsch]; but [the teacher] probably doesn't realise that he himself spoke quite affected [Hollandsch], when he said this. He must not indulge in this. There is a distinction between civilised and affected speech. - The first is praiseworthy, the second blameworthy.

(13) Alleen meende ik aanmerking te moeten maken op de uitspraak der Nederlandsche taal, welke de onderwijzer te letterlijk opvatte en ook spreken liet

(Beeloo, April 1854, 89: 123 [NHA])

The only comment I made was on the pronunciation of the Dutch language, which the teacher spoke and taught too literally.

These comments are in line with what we would expect based on official discourse, where standard language ideology had taken hold by the early nineteenth century. However, such comments are rather the exception than the rule. In the majority of inspection reports there is no reflection on language use, and no metalanguage signaling policing practices. This is surprising given the tension between the promotion of the standard in official discourse, and the use of dialect in everyday life, which was obviously normal for the vast majority of the population. The question is why there is so little reflection on actual language use.

A possible answer is that the spoken language was not on the curriculum and that school inspectors had enough other topics to direct their attention to (cf. Langer 2011: 180-181). As argued above (Section 10.3.2), there were serious limitations to language norm transmission in education. Also, some school inspectors were officials and local or church authorities rather than pedagogues and teachers. They focused their attention on organisational and financial issues rather than to the content and quality of teaching. However, there is more to account for the silence in linguistic matters, for which we have to return to the concept of standard language ideology. Lodge (2004: 217) explains that in standard language ideology

the ideal state of a language is one of uniformity, the standard form is inherently superior to other varieties [...]. Language is rigidified, and the distinction between what is correct and what is incorrect sharply delineated. The boundaries between one language and the next are made clear-cut and associated inseparably with nationality. The elasticity and flexibility of vernacular speech with the notion of dialect continua are firmly rejected. 
This description ties in with the discursive split into standard and non-standard that has been referred to throughout the present book. In Chapter 3, it has been argued that the contemporary sociolinguistic situation may qualify as diaglossic, which was however supplemented by an ideology of diglossia in the Late Modern period. Lodge (2004) writes about eighteenth-century French, a textbook example of the rise of SLI and political efforts at centralisation and nationalisation. In his study of metalanguage in the diaries of French glazier Jacques-Louis Ménétra, Lodge tries to capture the way ordinary people viewed language before the hegemony of standard language ideology. Like the majority of school inspectors in our case study, Ménétra fails to mention linguistic variation, or standard-dialect opposition, in a time when official discourse was steeped in standard language ideology. This is due, Lodge argues, to the fact that before the advent of standard language cultures, people were used to dealing with situations of multilingualism, variation and dialect continua. Before the nineteenth century, multilingualism in different forms was the norm rather than the exception (Vogl 2012). Variation, in other words, was "so much part of the natural world as to go without saying", and people dealt with it through different forms of accommodation (Lodge 2014: 212).

This clash of ideology and practice can also be seen in the reports of many school inspectors. Despite being representatives of official policies and discourses, they were also men of practice, who dealt with teachers, parents and officials from different regions and with various social backgrounds on a daily basis. They lived and worked in a society where variability in the spoken language was self-evident and not problematic. The rise of standard ideology would alter the way people viewed this multilingualism, but it had not yet done so in the first half of the nineteenth century. Standard language ideology was not yet accompanied by a generally accepted and lived standard language culture, that is, by a socially firmly established standard language, with standard ideology as the hegemonic language ideology (Milroy 2001: 535). This may explain why the majority of school inspectors did not comment on dialect use in the classroom, or at least did not consider it problematic and significant enough to warrant much attention.

\subsection{Language norms in teaching materials}

The school inspection reports provide insight into teaching practices and the role of SLI in these practices. Teaching, including language teaching, also depended on teaching materials such as reading matter, spelling guides and grammar books. Reading matter, in particular, was used widely in the eighteenth century, and was at that time more important than explicit instruction through spelling guides and grammar books. Following the educational discourse of change, and in line with 
the new focus on a national standard in the early nineteenth century, evidenced by the prominent role played by language in the new school acts (Section 10.2.3), a plethora of new teaching materials became available in the early nineteenth century. An important question is whether the new language norms were implemented in these new materials. In Section 4.5, it was shown that Weiland's (1805a) preference for the historical synthetic genitive was repeated in other grammar books from the period of 'national' grammar. In this section, we focus on two orthographical phenomena that will also be discussed in Chapter 11. In addition, we are less concerned here with the grammatical tradition, focusing instead on reading matter and on relatively accessible spelling and grammar guides meant for use in schools.

The first phenomenon that we will consider is the representation of the long vowels /a:/, /y:/, /e:/ and /o:/ in open syllables. In closed syllables, these were traditionally represented by $\langle$ ae $>,<$ ue $>$, $<$ ee $>$ and $<$ oe $>$, though considerable variation existed throughout the history of Dutch. In the Early and Late Modern period, lengthening by $<\mathrm{e}>$ gradually changed into lengthening by doubling the original vowel ( $<$ aa $>,<$ uu $>,<$ oo $>$ ). According to Siegenbeek (1804a), digraphs such as $<$ aa $>$ should not be used in open syllables, where single graphemes should be used instead, as in samen 'together', ruzie 'quarrel', ezel 'donkey' and open 'open'. In addition, Siegenbeek (1804a) rejected morphological spellings in this context. This means that the plural of taal 'language', for example, should be spelled talen, not taalen. The latter option would be on analogy with the singular, but Siegenbeek rejected this type of analogy. Similarly, the plural of buur 'neighbour' was buren, not buuren, and so on. Until Siegenbeek, writing practices varied, and the plural of taal, for example, can be found as talen, taalen and taelen.

A further complication is that in the case of long $e$ 's and o's, a subcategory of these words did require $<$ ee $>$ and $<00>$ in open syllable, according to Siegenbeek (1804a). The input to Standard Dutch came form North Hollandic dialects in this case, and in North Holland, and in Amsterdam in particular, etymologically different kinds of $e$ 's and $o$ 's had merged into one long $e$ and one long $o$ (see Section 11.3.1 and the references there). The general rule of a single grapheme for long vowels in open syllable did not apply to those long $e$ 's and $o$ 's which were the monophthongised result of the West Germanic diphthongs * $a i$ and ${ }^{*} a u$, such as steen 'stone' and boom 'tree'. Thus, the plural of these nouns should be spelled steenen and boomen. For many speakers in the northern and western parts of the language area, this was a purely orthographical rule, based on a phonological distinction that had long disappeared.

The orthographical distinction between the two types of $e$ 's and o's dates back to the sixteenth century, but other writing practices were also in use in subsequent periods. If we term Siegenbeek's system phonology based, we could call writing systems that made use of the morphological principle morphological. In such systems, 
a digraph is used in open syllables if there is a root form with a digraph, such as a singular form (see also Rutten \& van der Wal 2014: 35). These two systems differ where originally diphthongs are found in syllables that lack analogy with a root form, such as teeken 'sign' and toovenaar 'wizard'. Finally, irrespective of any phonological or morphological considerations, writers can opt for either a single grapheme or a digraph in every open syllable, for example talen, buren, stenen, bomen, or taalen, buuren, steenen, boomen. Such systems are called syllabic. All the systems mentioned can be found in seventeenth- and eighteenth-century Dutch (Rutten \& van der Wal 2014: 68, 70).

The second phenomenon concerns the spelling of the second and third person singular and the second person plural of verbs with $d$-stems. In Early and Late Modern supralocal Dutch, $t$ is the suffix of these categories and is attached to the root of the verb. On analogy with a form such as zij loopt 'she walks', that is loop+t, Siegenbeek (1804a) prescribed zij wordt 'she becomes', zij antwoordt 'she answers', $z i j$ houdt 'she holds', and so on in the case of verbs with $d$-stems. This resulted in the digraph $<\mathrm{dt}>$. Since Dutch has final devoicing, $<\mathrm{t}>$ was also in use to represent the actual sound /t/, for example zij wort. Finally, $<\mathrm{d}>$ was in use to avoid the digraph and to still signal the root of the verb, for example $z i j$ word. All three options are found in historical Dutch.

In both cases, long vowels and $d$-stems, Siegenbeek's (1804a) prescription is fairly complicated, with etymological considerations (in the case of the $e$ 's and $o$ 's) and analogical reasoning (in the case of the $d$-stems) leading to orthographical choices lacking a transparent relationship to pronunciation. In order to establish the implementation of Siegenbeek's prescriptions in teaching materials, we will investigate first how these orthographical variables were represented in eighteenth-century materials, and then compare the results to their representation in nineteenth-century materials.

The first period ranges from 1750 to 1804 , the second from 1805 to 1850. For the first period, we selected twenty publications that were demonstrably used in education in this period. ${ }^{5}$ The selection includes reading materials with a long tradition,

5. The list includes: Nieuwe Spiegel der Jeugd of Franse Tirrany (anon., 1752), J van Belle, Korte Schets der Nederduitsche Spraakkonst (1755), C. D. van Niervaart, Opregt Onderwijs van de Letter-Konst (1758), B. Hakvoord, Opregt Onderwijs van de Letter-Konst (1761), K. van der Palm, Nederduitsche Spraekkunst voor de Jeugdt (1761), De Historie van den Koninglyke Propheet David (anon., 1770), K. Stijl/L. van Bolhuis, Beknopte Aanleiding tot de Kennis der Nederduitsche Taal (1776), H. van Alphen, Proeve van Kleine Gedichten voor Kinderen (1778), B. Cramer, Geldersche Trap der Jeugd (1780), Spreuken des Alderwysten Konings Salomoni (anon., 1784), C. de Gelliers, Trap der Jeugd (1788), Trap der Jeugd (anon., 1791), L. van Bolhuis, Beknopte Nederduitsche Spraakkunst (1793), W. van Oosterwijk Hulshoff, De Geschiedenis van Jozef(1797), G. van Varik, Rudimenta of Gronden der Nederduitsche Spraake (1799), H. Wester, Bevatlyk Onderwys in de Spel-en Taalkunde (1799), J. Buis, Natuurkundig Schoolboek (1800), D. Nyland, Nieuw Verbeterde 
such as Trap der Jeugd, Spreuken van Salomon and Historie van David, and reading materials that were first published in this period under the influence of the educational discourse of change, such as van Alphen's Proeve van Gedichten voor Kinderen, van Oosterwijk Hulshoff's Geschiedenis van Jozef, and Buis's Natuurkundig Schoolboek. In addition, grammatical works were taken into account that were perhaps not used in the classroom, but that were still oriented to schoolteachers, such as van Belle (1755), van der Palm (1769) and Stijl/van Bolhuis (1776) (see also Chapter 4).

In particular for the $d$-stems, quite a few publications give an explicit norm. If not, they are usually categorical in their use, with only some exceptions. Table 1 shows that the three options $\langle\mathrm{d}\rangle,<\mathrm{t}\rangle$ and $\langle\mathrm{dt}\rangle$ were all in use in the 1750s and 1760s, after which a general preference for $<\mathrm{dt}>$ developed. Siegenbeek (1804a), therefore, confirmed a practice that had already been established in schoolbooks towards the end of the eighteenth century.

Table 1. Orthographical practice and prescriptions in twenty books from the eighteenth century

\begin{tabular}{lccc}
\hline & & $\mathrm{V}$ owels & $\mathrm{d}$-stems \\
\hline Anon., Spiegel der Jeugd & 1752 & $\mathrm{v} / \mathrm{vv}$ & $\mathrm{d}$ \\
van Belle, Korte schets & 1755 & $\mathrm{vv}(\mathrm{m})$ & $\mathrm{d}$ \\
Niervaart, Opregt onderwijs & 1758 & $\mathrm{vv}(\mathrm{ph})$ & $\mathrm{t}$ \\
Hakvoord, Opregt onderwijs & 1761 & $\mathrm{vv}(\mathrm{m})$ & $\mathrm{d}$ \\
van der Palm, Nederduitsche Spraekkunst & 1769 & $\mathrm{vv}(\mathrm{ph})$ & $\mathrm{d} / \mathrm{dt}$ \\
Anon., Historie van David & 1770 & $\mathrm{vv}(\mathrm{ph})$ & $\mathrm{d}$ \\
Stijl/van Bolhuis, Beknopte Aanleiding & 1776 & $\mathrm{vv}(\mathrm{m} / \mathrm{ph})$ & $\mathrm{dt}$ \\
van Alphen, Proeve van Kleine Gedichten & 1778 & $\mathrm{vv}(\mathrm{ph})$ & $\mathrm{dt}$ \\
Cramer, Geldersche Trap der Jeugd & 1780 & $\mathrm{vv}(\mathrm{m})$ & $\mathrm{d} / \mathrm{dt}$ \\
Anon., Spreuken van Salomon & 1784 & $\mathrm{v} / \mathrm{vv}(\mathrm{ph})$ & $\mathrm{d}$ \\
de Gelliers, Trap der Jeugd & 1788 & $\mathrm{vv}(\mathrm{m})$ & $\mathrm{dt}$ \\
Anon., Trap der Jeugd (Nut) & 1791 & $\mathrm{vv}(\mathrm{m})$ & $\mathrm{dt}$ \\
van Bolhuis, Beknopte Nederduitsche Spraakkunst & 1793 & $\mathrm{v}$ & $\mathrm{dt}$ \\
van Oosterwijk Hulshoff, Geschiedenis Jozef & 1797 & $\mathrm{vv}(\mathrm{m})$ & $\mathrm{dt}$ \\
van Varik, Rudimenta & 1799 & $\mathrm{vv}(\mathrm{m})$ & $\mathrm{dt}$ \\
Wester, Bevatlyk Onderwys & 1799 & $\mathrm{vv}(\mathrm{m})$ & $\mathrm{dt}$ \\
Buis, Natuurkundig Schoolboek & 1800 & $\mathrm{vv}(\mathrm{m})$ & $\mathrm{dt}$ \\
Nyland, Nieuw Verbeterde Trap der Jeugd & 1800 & $\mathrm{v}$ & $\mathrm{d}$ \\
Anon., Levensschetsen (Nut) & 1803 & $\mathrm{vv}(\mathrm{m})$ & $\mathrm{dt}$ \\
van Heijningen Bosch, Kleine Kindervriend & 1804 & $\mathrm{vv}(\mathrm{m})$ & $\mathrm{dt}$ \\
\hline
\end{tabular}

Trap der Jeugd (1800), Levensschetsen van Vaderlandsche Mannen en Vrouwen (1803), M. van Heijningen Bosch, De Kleine Kindervriend (1804). See Schoemaker (2018) for more details about the selection process. 
For the long vowels, a more complicated picture emerges. From each publication, we took the first fifty tokens of /a:/, /y:/, /e:/ and /o:/ in open syllable. These were then first scrutinised for syllabic systems, preferring either one grapheme (v) or a digraph (vv). If there was variation between single graphemes and digraphs, we investigated whether morphological spelling principles ( $\mathrm{vv}(\mathrm{m})$ ), or in the case of $e$ 's and o's, phonology-based considerations conditioned the variation ( $\mathrm{vv}(\mathrm{ph})$ ). Table 1 shows that syllabic spelling systems are rare. Instead, there is variation of phonological and morphological systems in the 1750s, 1760s and 1770s, after which the morphology-based system takes over. This system is easier, of course, as it applies to all four long vowels in open syllable, whereas the phonology-based system only applies to $e$ 's and $o$ 's. The Spiegel der Jeugd (1752) does not seem to have any of the writing systems discussed, and appears to distribute single graphemes and digraphs randomly. Contrary to the case of $<\mathrm{dt}>$, Siegenbeek's (1804a) choice for the phonology-based system ran counter to the evolution in writing practices in eighteenth-century schoolbooks.

For the second period, running from 1805 to 1850, we selected a larger number of schoolbooks and language guides as there were many more publications in use due to the increase in schoolbook production in the aftermath of the educational discourse of change, and the subsequent new educational policies (Section 10.2). Thus, we were able to distinguish two types of publication: grammar books meant for use in schools, and reading materials. Twenty grammar books were scrutinised, ${ }^{6}$ and eighteen books meant for reading practice. ${ }^{7}$ As with the first period, we focused on books that were widely used, and often saw several reprints.

6. The list of grammatical works includes: M. Siegenbeek, Kort Begrip der Verhandeling over de Nederduitsche Spelling (1805), D. du Mortier, Letterkunst voor de Jeugd (1805), C. Wertz, Rudimenta of Gronden der Nederduitsche Taal (1805), P. Weiland, Beginselen der Nederduitsche Spraakkunst (1805), P. Weiland, Nederduitsche Spraakkunst ten dienste der Scholen (1806), H. Wester, Bevattelijk Onderwijs in de Spel- en Taalkunde (1810 [1797]), A. Vermeij, Eerste Beginselen der Hollandsche Spraakkunst (1818 [1810]), M. Siegenbeek, Grammatica of Nederduitsche Spraakkunst (1814), N. Callegoed, Iets over de Nederduitsche Taalkunde (1836 [1818]), J. Laukens, Eerste Beginselen der Nederduitsche Spraakkunst (1824[1818]), N. Anslijn, Rudimenta of Gronden der Nederduitsche Taal (1819-1827), J. S. Kirchdorffer, Nederduitsche Spraakkunst ten dienste der Scholen (1825 [1820]), H. Kremer, Bevattelijk Onderwijs in de Spel-en Taalkunde (1822), R. G. Rijkens, De Leermeester in de Spelkunde (1829), A. C. Oudemans, Eerste Beginselen der Nederduitsche Taal (1830), J. C. de Wilde, Beginselen der Nederduitsche Spraakkunst (1836 [1830]), P. J. Prinsen, Beginnend Onderwijs in de Nederduitsche Taal (1837), G. Kuyper, Beginselen der Nederlandsche Spraakleer (1844), A. Hagoort, Eerste Gronden der Nederduitsche Taal (1845), G. C. Mulder, Nederlandsche Spraakkunst voor Schoolgebruik (1852[1848]). More information in Schoemaker (2018).

7. The list of reading materials includes: W. van Oosterwijk Hulshoff, De Geschiedenis van Jozef (1806), M. Nieuwenhuijzen, Leeslesjes bij het Kunstmatig Lezen (1807), Levensschetsen van Vaderlandsche Mannen (anon., 1809), J. Buis, Natuurkundig Schoolboek (1809), M. Heijningen 
Whereas the eighteenth-century results displayed quite some variation, with various norms and writing systems in competition with one another, the nineteenth-century results are completely homogeneous. All 38 publications adopt $<\mathrm{dt}>$ as the only correct option for second and third person singular, and second person plural forms of $d$-stem verbs. All 38 publications also follow Siegenbeek (1804a) in the case of the spelling of long vowels in open syllable; that is, they adopt a single grapheme in open syllables, except for the representation of the long $e$ 's and $o$ 's that derive from West Germanic diphthongs.

This means that the implementation of the Siegenbeek spelling in language teaching materials in the first half of the nineteenth century was extremely successful right from the start. Schoemaker (2018) shows that this pattern is not unusual, and in fact applies to a range of orthographical variables. Within one year after the publication of Siegenbeek's official spelling in 1804, books oriented to the field of education adopted the newly prescribed orthographical conventions. Some books made this explicit even on the title page or in the preface. As early as 1805, du Mortier entitles his "grammar for the youth": Letterkunst voor de jeugd, of handleiding om de kinderen in de scholen te oefenen in de Nederduitsche Spelling van den heer Matthys Siegenbeek, that is 'Grammer for the youth, or guide to teach the children the Dutch spelling of Matthijs Siegenbeek'. Similarly, Wertz (1805: i-ii) indicates that his book is in accordance with the officialised spelling of Siegenbeek (1804a). Someone like Wester, a prolific language commentator himself in the late eighteenth century, who had prescribed the morphological spelling of long vowels (see Table 1), switched to the phonology-based system adopted by Siegenbeek (1804a). Other authors, too, switched to the Siegenbeek spelling after 1804. W. van Oosterwijk Hulshoff, for example, published his Geschiedenis van Jozef in 1797, while a fifth edition came out in 1806 . Whereas the earlier publication was characterised by the morphological system with respect to the long vowels, the 1806 edition followed Siegenbeek (1804a). A similar change can be witnessed in the Natuurkundig schoolboek by J. Buis. The implication of this successful implementation after 1804 is that the written language that children came into contact with was very strongly influenced by Siegenbeek (1804a).

Bosch, De Kleine Kindervriend (1809), J. van Bemmelen, Nieuw Vermakelijk Spel-en Leesboek (1810), H. Wester, Schoolboek Geschiedenissen van ons Vaderland (1810), B. Verweij, Kort Begrip van de Bijbelsche Geschiedenis (1813), J. van Dobben, Zedekundig Leesboekje (1816), H. Kremer, Bijbelsche Geschiedenissen (1817), H. van Alphen, Kleine Gedichten voor Kinderen (1820), N. Anslijn, De Brave Hendrik (1822), P. J. Prinsen, Gemakkelijk Leesboekje voor Kinderen (1824), Trap der Jeugd (anon., 1827), J. Kuijpers, Vader Gerhard onder Zijne Kinderen (1833), Godsdienstig Onderwijs voor Jonge Kinderen (anon., 1835), R. G. Rijkens, Kleine Buffon of Natuurlijke Historie (1835), J. H. Nieuwold, Het is Goed dat er Vele Menschen zijn (1836). See also Schoemaker (2018). 


\subsection{Final remarks}

In around 1800, a period of intense nation building led to concrete language and language-in-education policies in the northern Low Countries, including the official codification of the national language and a series of school reform acts. Thus, the rise of standard language ideology in the late eighteenth century immediately affected policy in the late eighteenth and early nineteenth centuries. An important question pertains to the implementation of these policies in the field of education. As part of the educational reforms, a national school inspection system was established. School inspection reports provide detailed information about the implementation of policies in local schools. In line with the nationalist ideology and the official policy, inspectors and schoolteachers imposed the national language on pupils in a process of norm transmission in classroom practices. Likewise, the reports show evidence of inspectors and teachers policing non-standard language use in the classroom. Moreover, teaching materials display a quick and almost categorical switch to the officialised norms. This applies not only to grammar books, but also to reading materials. It appears that the implementation of the official language norms was successful with respect to both teaching practices and teaching materials.

At the same time, however, evidence of policing non-standardness is relatively sparse in the school inspection reports when compared to the number and size of the archival sources. Apart from practical reasons related to teaching programmes and educational traditions, an important explanation may lie in the fact that standard language ideology was still primarily just that: an ideology informing policy, not a lived experience in the wider language community. Many inspectors and teachers probably still accepted the variability characteristic of the contemporary language situation, acknowledging that the implementation of new policies is often a gradual process taking up a considerable amount of time. 


\section{The effects of planning on usage With Andreas Krogull}

\subsection{Introduction}

Did the nationalistically inspired language planning efforts from the first decade of the nineteenth century exert any influence on language use? This question is at the heart of the present chapter, which focuses on the implementation of the national standard variety in actual language practices (cf. Section 10.1). This study does not, however, aim to arrive at an assessment of the ability of identifiable individuals to align with the national language planning regulations. Such an approach would require detailed qualitative analyses, taking into account issues of inequality such as socially differing schooling opportunities as well as the possibly varying social consequences of not conforming to the officially codified version of the language. Just as nowadays, however, individuals in the early nineteenth century were not obliged to follow the official prescriptions. The policy primarily aimed at the educational and administrative domains. While the role of education was certainly meant to be instrumental in the dissemination of the national language (Chapter 10), this does not imply a direct relationship between private and public language use outside schools on the one hand, and educational success, or the lack thereof, on the other.

The goal of this chapter is to assess quantitatively, on the basis of a sizeable corpus of original documents, changes in the Dutch language from the eighteenth century to the nineteenth century that can be related to the linguistic prescriptions and proscriptions issued by the government in order to determine the effectiveness of the language planning efforts in a general way, that is, with respect to and at the level of the community. The effectiveness of language planning efforts has hardly ever been investigated. There is a wide academic discourse on standardisation, prescriptivism, language planning and policy, but particularly in historical contexts, the results of planning efforts are often taken for granted. For example, in histories of western European languages such as Dutch, English, French and German, a lot of ink is usually spent on selection and codification whereby the influence of Early and Late Modern norms and prescriptions is more often than not implied instead of attested (Langer 2011; Rutten, Vosters \& Vandenbussche 2014; Poplack et al. 2015; Anderwald 2016). 
Investigating policy success, or at least possible effects of language planning on usage patterns, is a necessary requirement of any theory of standardisation. On the assumption that standardisation, understood as norm convergence, in a given community may result from very different forces, such as contact, mobility, writing traditions and urbanisation, a question that also needs to be answered is to what extent planning efforts have influenced the standardisation of a particular language.

This chapter will consider such questions as how effectiveness should be measured, and how policy success should be determined. In endeavouring to answer these questions a perspective 'from below' will be taken, in line with current approaches in historical sociolinguistics (Elspaß 2005; Rutten \& van der Wal 2014). This means that a corpus of texts relatively close to the everyday experiences of historical actors will be used to detect changes in usage patterns from before and after the policy. We will introduce the corpus in 11.2. In Sections 11.3 and 11.4, a selection of orthographic and morphosyntactic variables will be investigated. In 11.3, we first a vocalic variable, then two consonantal variables. Section 11.4 discusses two morphosyntactic variables, viz. the genitive case and relativisation. Section 11.5 contains the final remarks.

\subsection{The Going Dutch Corpus}

A sociolinguistic corpus was built for the specific purpose of determining the influence of the Dutch schrijftaalregeling 'written language regulation' of 1804 and 1805, i.e. of the official orthography (Siegenbeek 1804a) and grammar (Weiland 1805a). The corpus is named after the project for which it was built, hence Going Dutch Corpus or GDC. The GDC consists of two cross-sections in chronological time. The first one is made approximately one generation before the language policy, and the second one around one generation after 1804/1805. Allowing for twenty-year windows to ensure that enough archival sources were available, this led to a make-up of the GDC with period 1 spanning the years 1770-1790, and period 2 spanning the years 1820-1840, thus with approximately half a century in between. The diachronic difference is the most important external variable built into the GDC.

In line with the approach to language history 'from below', the main sources of the GDC are so-called ego-documents, in particular private letters, diaries and travelogues. Private letters could partly be taken from the previously compiled Letters as Loot Corpus (LALC, see Rutten \& van der Wal 2014), viz. for period 1, although additional letters had to be found to meet the requirements of the GDC in terms of region and gender (see below). All other texts were manually transcribed from digital images of the original archival sources. 


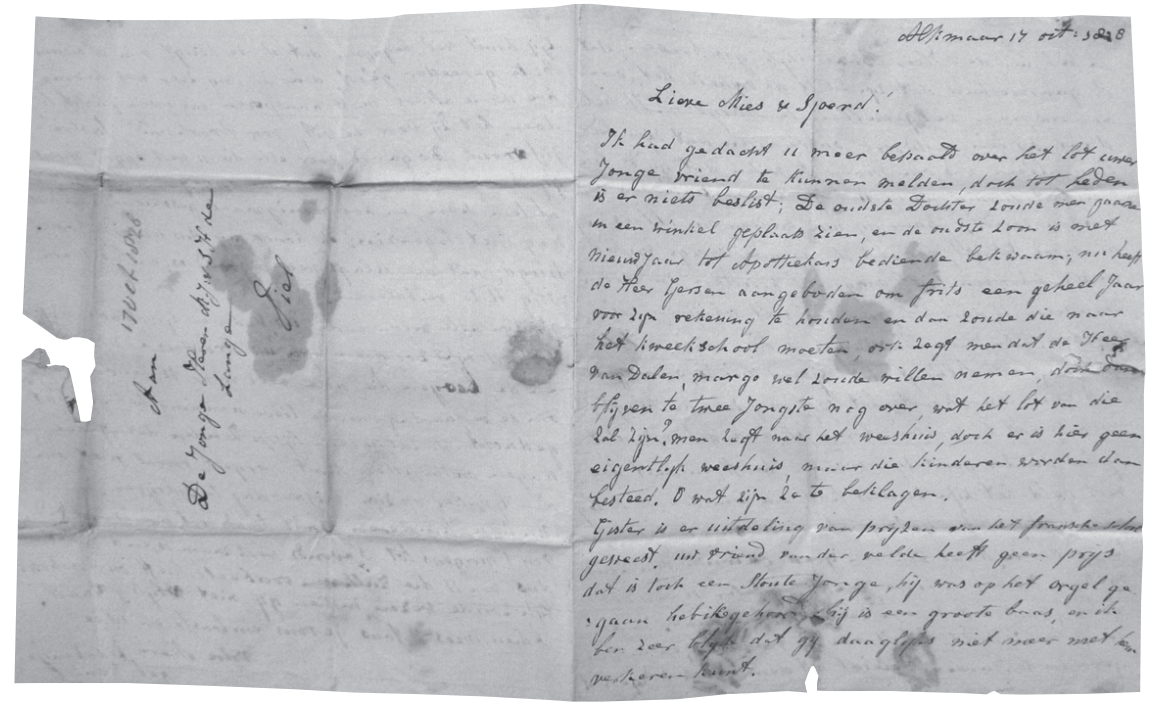

Figure 1. Private letter by Anna de Lange (17 October 1828, De Lange family archive, Regionaal Archief Alkmaar)

The subcategorisation of ego-documents is challenging. We decided to distinguish between private letters on the one hand, and diaries and travelogues on the other. Private letters have become the prime sources in historical sociolinguistics, and given their principally dialogic nature as well as to enhance comparability with other corpora and analyses, we treated them as one subgenre within the category of ego-documents. Diaries and travelogues, which became particularly popular during the eighteenth and nineteenth centuries, are often difficult to distinguish from one another. There are many mixed sources, while they are in principle to be kept separate from memoirs and autobiographies, which are usually conceptualised at a much later point in time, with considerable temporal distance between the act of writing and the reported events. Considering that the LALC also comprises letters, the GDC extends existing research by adding another layer of ego-documents.

In addition, the GDC comprises newspapers. By including newspapers, we are able to compare manuscript sources to print sources, which is particularly relevant in a situation of top-down language planning. A major issue is whether editors and printers were inclined to adopt the official norms, and whether this enlarges the differences between manuscript and print language. Sociolinguistically, newspapers are interesting as they were still relatively local. There were a lot of local and regional newspapers, and the geographical spread of newspapers was much more limited than that of many other print sources. Thus, the GDC is a diachronic multi-genre 


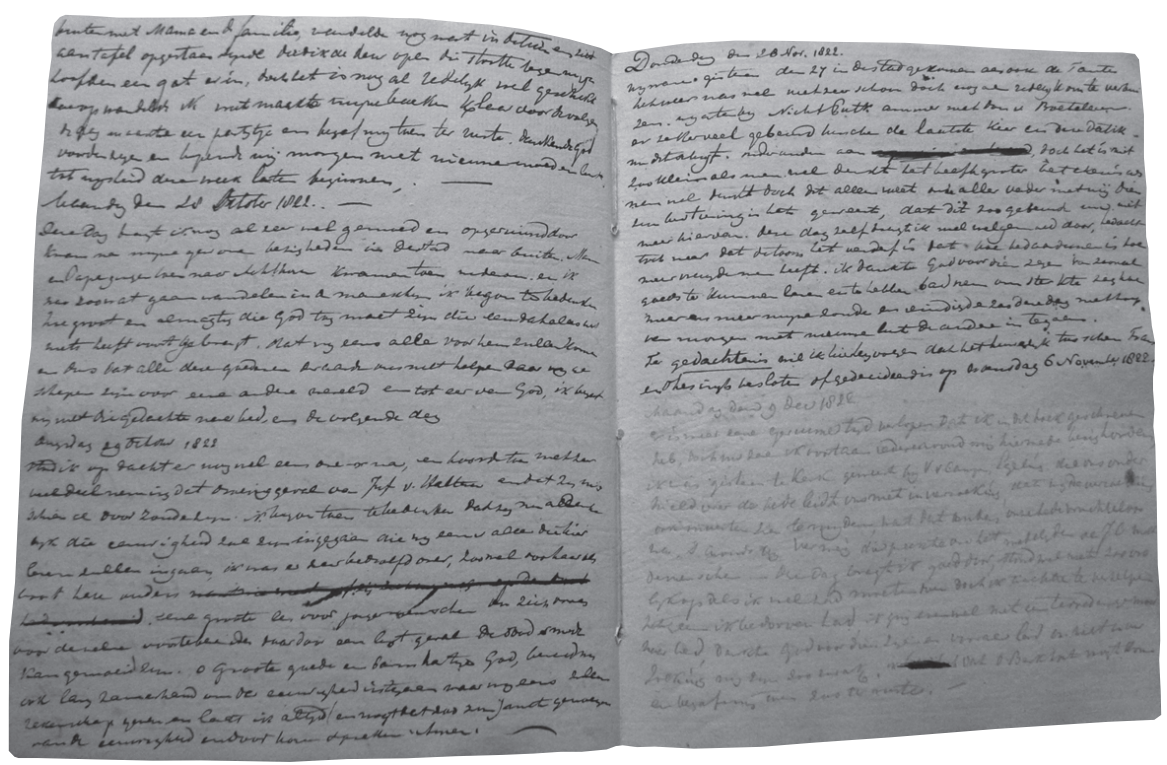

Figure 2. Diary by Pieter Gladius Hubrecht (1822, Hubrecht family archive, Erfgoed Leiden en Omstreken)

corpus, developed on the assumption that diachronic changes will affect different genres in different ways.

Historically, geographical variation is essential. The GDC incorporates two geographical dimensions. First, seven regions within the northern Low Countries are represented. In addition to the three westernmost regions that dominate the LALC, viz. Zeeland, South Holland and North Holland, the GDC moves to the east and north by including texts from Brabant, Utrecht, Friesland and Groningen (see the map), thus shifting away from the traditional focus on Zeeland and, in particular, Holland. Obviously, it is desirable that future research also includes the remaining eastern regions.

Secondly, by incorporating several other regions, another geographical distinction can be operationalised, viz. between the centre and the periphery. North Holland, South Holland and Utrecht make up the centre of the language area, while Friesland, Groningen and Brabant can be considered as peripheral with respect to this centre. Zeeland was historically part of the centre, particularly in the seventeenth century, but as this balance was shifting in later times we decided to keep Zeeland apart (see also Krogull 2018).

Finally, gender is a social variable that can be applied to the ego-documents. Incorporating the category of male and female gender also warrants comparability to the LALC. The LALC is furthermore socio-economically stratified in terms of lower, middle and upper ranks. The upper ranks in the LALC are only relatively 


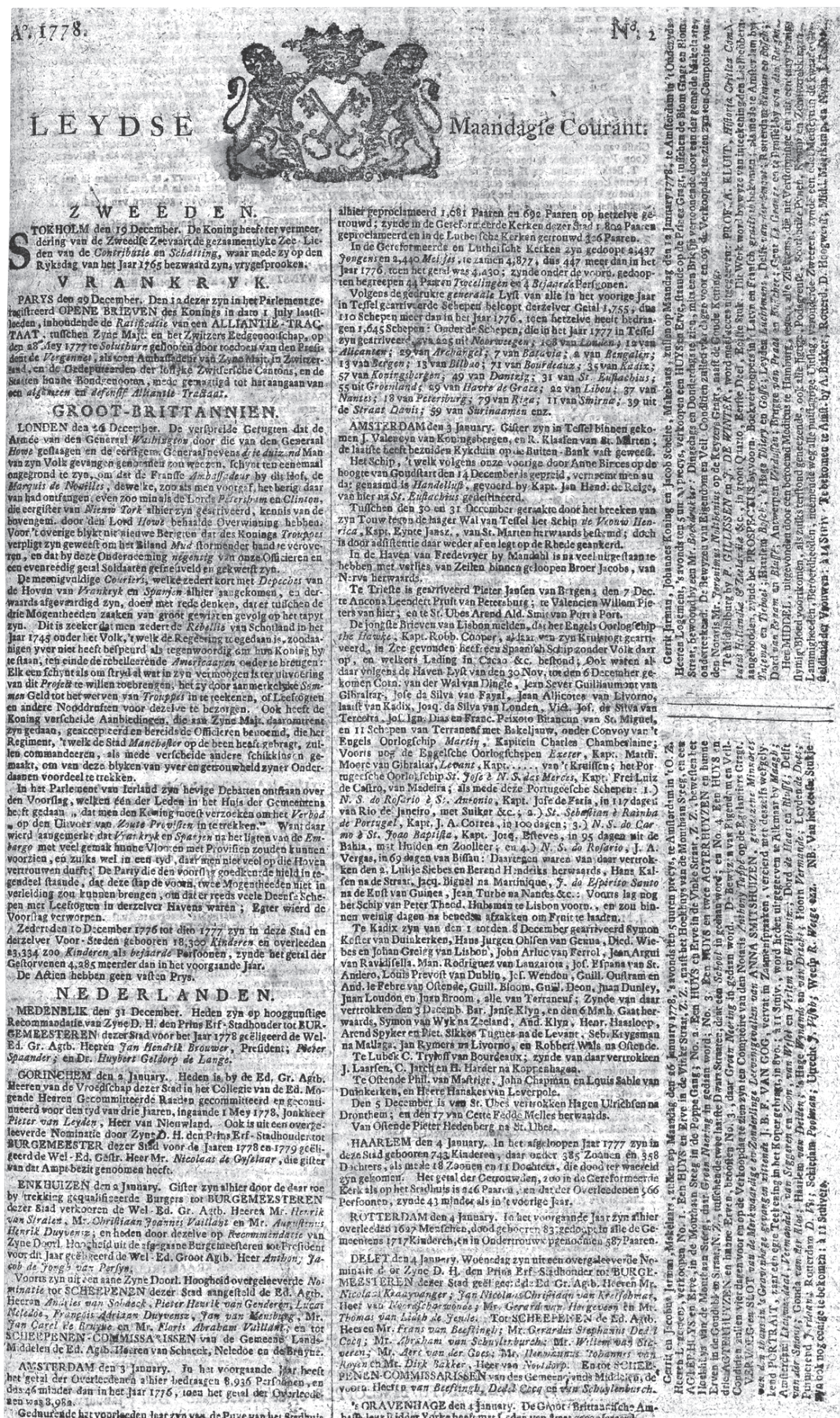

Figure 3. Newspaper: Leydse courant (5 January 1778) (Delpher.nl) 


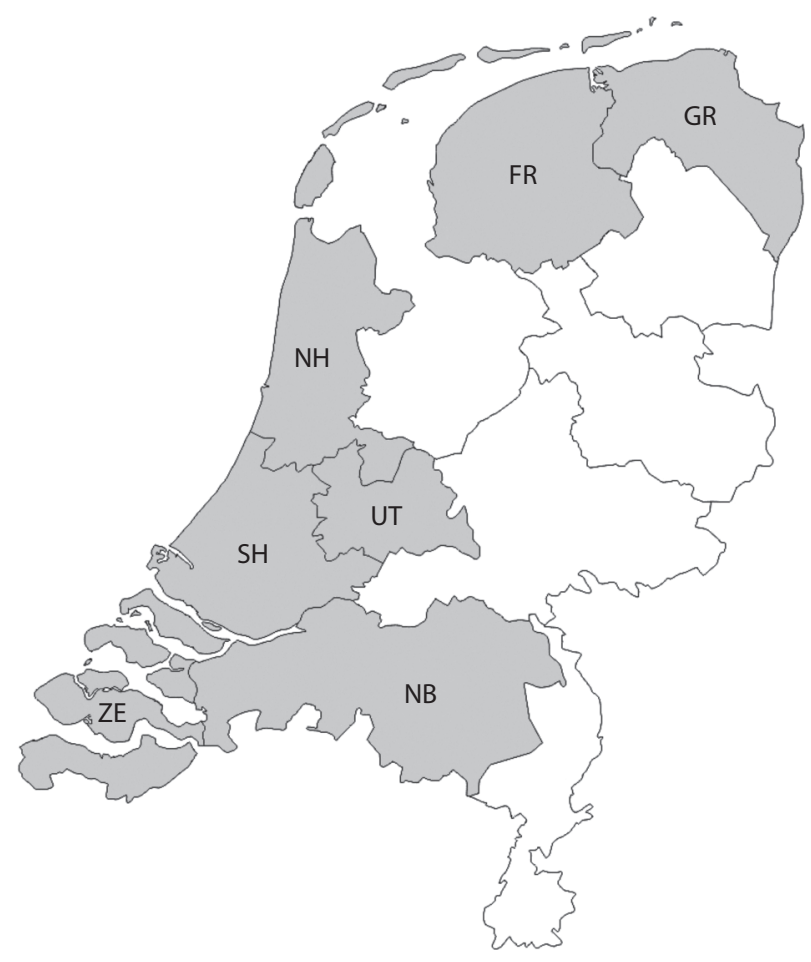

Figure 4. Map of the Netherlands indicating the regions represented in the GDC (FR $=$ Friesland, $\mathrm{GR}=$ Groningen, $\mathrm{NB}=$ North Brabant, $\mathrm{NH}=$ North Holland, $\mathrm{SH}=$ South Holland, UT $=$ Utrecht, ZE $=$ Zeeland)

upper, in that they are the socio-economically most privileged group in the corpus, but in society as a whole, there was another even more privileged layer, viz. the gentry and the nobility. From the perspective of society as a whole, therefore, the upper ranks in the LALC represent the upper-middle ranks. Within the GDC, we were not able to distinguish different social layers on account of a lack of sources related to the lower and lower-middle ranks. In terms of the LALC, the GDC mainly comprises ego-documents from the middle and upper ranks. More broadly speaking, we can say that most ego-documents in the GDC stem from the middle to the upper ranks of late eighteenth-and early nineteenth-century society, though excluding the very highest layer of the nobility. Writers in the GDC corpus have various occupations, including merchants, lawyers, officers, ministers and also well-to-do farmers.

In sum, the GDC comprises two periods, three genres, seven regions, and in the case of the ego-documents also two genders. When building the corpus, we worked with the hypothesis that, in terms orthographic and grammatical uniformity and 
standardisation, the newspapers would outperform the diaries and travelogues, which would in their turn surpass the private letters (Schneider 2013). During corpus compilation, this hypothesis led to different requirements for the three genres with respect to the minimal number of words. Our first aim was to gather newspaper texts of 5,000 words for each of the seven regions, making 35,000 words per period, and 70,000 words in total. Our second aim was to collect, for each of the seven regions, 10,000 words from diary and travelogue sources, i.e. 70,000 words for one period and 140,000 in total. Our third aim was to have 15,000 words from private letters for each region, i.e. 105,000 words, totalling at 210,000 words for two periods. Our fourth aim was to have the two genders more or less equally distributed across both types of ego-documents. Table 1 shows that we largely succeeded in compiling the desired corpus.

The entire GDC has 421,878 words distributed across the external variables as shown in Table 1. Period 1 contains 200 private letters written by 154 individuals, and 26 diaries and travelogues written by 25 individuals. Period 2 has 200 letters by 144 individuals, and 25 diaries and travelogues by 25 individuals.

Table 1. Overview of the Going Dutch Corpus

\begin{tabular}{llccr}
\hline & & Period 1 & Period 2 & Total \\
\hline Genre & $\mathbf{1 7 7 0 - 1 7 9 0}$ & $\mathbf{1 8 2 0 - 1 8 4 0}$ & \\
& Private letters & 105,427 & 105,299 & 210,726 \\
& Diaries and travelogues & 71,157 & 69,350 & 140,507 \\
& Newspapers & 35,323 & 35,322 & 70,645 \\
Region & Total genre & $\mathbf{2 1 1 , 9 0 7}$ & $\mathbf{2 0 9 , 9 7 1}$ & $\mathbf{4 2 1 , 8 7 8}$ \\
& North Holland & 30,256 & 32,368 & 62,624 \\
& South Holland & 30,225 & 33,547 & 63,772 \\
& Utrecht & 30,588 & 30,094 & 60,682 \\
& Centre & $\mathbf{9 1 , 0 6 9}$ & $\mathbf{9 6 , 0 0 9}$ & $\mathbf{1 8 7 , 0 7 8}$ \\
& Groningen & 28,875 & 30,323 & 59,198 \\
& Friesland & 30,757 & 30,949 & 61,706 \\
& North Brabant & 30,647 & 25,998 & 56,645 \\
& Periphery & $\mathbf{9 0 , 2 7 9}$ & $\mathbf{8 7 , 2 7 0}$ & $\mathbf{1 7 7 , 5 4 9}$ \\
& Zeeland & 30,559 & 26,692 & 57,251 \\
& Total region & $\mathbf{2 1 1 , 9 0 7}$ & $\mathbf{2 0 9 , 9 7 1}$ & $\mathbf{4 2 1 , 8 7 8}$ \\
& Male & 127,112 & 105,657 & 232,769 \\
& Female & 49,472 & 68,992 & 118,464 \\
& Total gender & $\mathbf{1 7 6 , 5 8 4}$ & $\mathbf{1 7 4 , 6 4 9}$ & $\mathbf{3 5 1 , 2 3 3}$ \\
\hline
\end{tabular}

The distribution across genres and regions is well balanced. There are a few cells where the desired word count is not reached, most prominently the regions of Brabant and Zeeland in period 2. This is due to a lower word count for private letters 
in Zeeland (11,489 words instead of 15,000), and a lower word count for diaries in the case of North Brabant (5,009 words instead of 10,000).

The gender distribution only applies to the private letters and the diaries and travelogues. Table 1 shows that male writers are overrepresented ( $72 \%$ male writers in period $1,60 \%$ in period 2). However, we prefer to argue that with 30 to $40 \%$ of the sources being written by female authors the GDC differs considerably from the traditional near absence of female writers in language histories.

Beside the GDC with original language data, we also created a normative corpus of grammar books and orthographies published in the eighteenth century and up to Siegenbeek (1804a) and Weiland (1805a). This was done in order to be able to contextualise the normative choices made by Siegenbeek and Weiland, and to advance and deepen the interpretation of the usage patterns found. A crucial issue, for example, is whether the prescriptions and proscriptions making up the schrifftaalregeling 'written language regulation' were unique, or in any case idiosyncratic, or instead fairly traditional choices all along. In the latter case, it could be more difficult to explain usage patterns in the second period that conform to the officialised language as immediate consequences of the language policy. In what follows, we will discuss the normative tradition preceding Siegenbeek (1804a) and Weiland (1805a) where necessary. ${ }^{1}$

\subsection{Orthography}

Krogull (2018) presents a range of case studies carried out on the GDC. We will not repeat all the results reported in these studies, and instead restrict ourselves to a summary discussion of the most relevant results for a selection of variables. We discuss one vocalic variable and two consonantal variables.

The vocalic variable concerns the spelling of etymologically different long e's in open syllable. It is an interesting variable as the various long $e$ 's had merged in large parts of the language area, including the central area of Holland, resulting in a writing system markedly different from the spoken language for large groups of speakers. The first consonantal variable concerns the choice between $\langle$ gt $>$ and $<$ cht $>$ in final position. Again, this was a much-debated issue during the eighteenth century, and etymology and morphology played an important role in these debates. The second consonantal variable concerns the choice between $\langle\mathrm{d}\rangle,\langle\mathrm{t}\rangle$ and $\langle\mathrm{dt}\rangle$ in final position in particular verb forms, which also has a morphological aspect.

1. For a detailed overview of the normative corpus as well as more background information on the GDC, see Krogull (2018). 


\subsubsection{Vowels}

The first variable concerns the representation of etymologically distinct long e's. Many Dutch dialects maintain the phonological difference between so-called softlong and sharplong vowels. These are the terms traditionally used in Dutch historical linguistics. Softlong $\bar{e}$ is a long $e$ developed through lengthening of the originally short vowels /E/ and /I/ in open syllables, for example the vowels in the first syllables in leven 'live' and hemel 'heaven'. Sharplong $\hat{e}$ is a long $e$ that developed through monophthongisation of the original diphthong $a i$, for example in steen 'stone' and heten 'be called'. Thus, both developments resulted in a long $e$. This merger is characteristic of many varieties spoken in the northwest of the language area, particularly in the northern parts of Holland. It is also part of the present-day standard variety.

However, the etymological difference is also preserved in many varieties. The coexistence of merging and non-merging varieties has led to various writing traditions, which can be summarised as follows (Rutten \& van der Wal 2014: 35-36). In phonology-based systems, the etymological difference is represented in the orthography. This is traditionally done by doubling the grapheme in the case of sharplong vowels in open syllable, for example sharplong steenen 'stones' and heeten 'be called' as opposed to softlong leven 'live' and hemel 'heaven'.

Writers for whom the historical difference had become opaque developed alternative spelling systems. In a morphologically-oriented system, open syllables received $<$ ee $>$ in analogy with closed syllables, and $<\mathrm{e}>$ in the absence of possible analogical forms, for example steenen because of the singular steen, and also leeven because of leef, but hemel with only $<\mathrm{e}>$. Finally, syllabic systems came into use which had either $<\mathrm{e}>$ or $<\mathrm{ee}>$ in open syllables, independent of phonological or morphological considerations, for example steenen, leeven and heemel, or stenen, leven and hemel.

In the eighteenth-century normative tradition, all three major types were promoted. Grammarians such as Moonen (1706) and many of his followers opted for the morphology-based system (Rutten 2011: Chapter 5). Ten Kate gave a detailed explanation of the etymological difference as early as in 1723. This position was also taken by Kluit (1763), and through him it became part of Siegenbeek's (1804a) prescriptions. This was not the only etymologically driven spelling choice by Siegenbeek, but it is still remarkable that he maintained the phonology-based system, based on an etymological difference between vowels that had merged in his native Holland region centuries before, viz. in the sixteenth century.

What is more, Rutten \& van der Wal (2014: 34-44) show that even in regions where the etymological difference is maintained until the present day, such as Zeeland, a remarkable shift in writing practices took place between the seventeenth 
and the eighteenth centuries. Sharplong and softlong e's are neatly separated in their corpus of seventeenth-century private letters from that area, along the lines of the phonology-based system with <e > for softlong vowels in open syllables, and <ee $>$ for sharplong vowels. In their eighteenth-century data, however, both types of long $e$ pattern similarly attracting mostly $<$ ee $>$. This means that the merger, alien to the area of Zeeland, became represented in the spelling. The dominant approach was a syllabic system with <ee>. Rutten \& van der Wal (2014: 67-72) show that this development mirrored the changes taking place in Amsterdam, where however the merger was also part of the spoken language. In sum, the phonology-based system gave way to a syllabic system, and this happened both in Amsterdam and Zeeland, despite the fact that Zeeland maintained the etymological difference in the spoken language.

It seems that the official codification of the phonology-based system by Siegenbeek (1804a) was an intervention relatively alien to contemporary writing practices. To investigate its success, we selected the fifteen most frequent words with the sharplong variant, and the ten most frequent words with the in itself more frequent softlong variant. The sharplong items sought for included eene $e^{*}$ eenige $e^{*}$

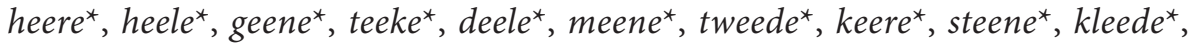
vreeze $e^{\star}$, leere $e^{\star}$ and beene $e^{\star}$. These items should be considered as search strings as they represent inflected and derived forms as well, for example, deele comprises the verb deelen 'to separate', the noun deelen 'parts' as well as verbs such as mededeelen 'inform' and veroordeelen 'condemn'. Similarly, the softlong items included deze $e^{*}$, weder $^{\star}$, mede $^{\star}$, geve $^{\star}$, tegen $^{\star}$, neme $e^{\star}$, zeker $^{\star}$, leve $^{\star}$, vele $^{\star}$, beter $^{\star}$.

The corpus search generated 6,086 genuine results for softlong $\bar{e}$, and 3,487 tokens for sharplong $\hat{e}$. Table 2 gives the diachronic overview of the orthographic representation of the long $e$ 's in the GDC.

The results for the sharplong variant confirm the earlier results obtained by Rutten \& van der Wal (2014): the digraph <ee> is preferred. This is already the

Table 2. Diachronic distribution of the representation of sharplong and softlong $e$ 's in the GDC

\begin{tabular}{|c|c|c|c|c|}
\hline & \multicolumn{2}{|c|}{$\begin{array}{l}\text { Period } 1 \\
1770-1790\end{array}$} & \multicolumn{2}{|c|}{$\begin{array}{l}\text { Period } 2 \\
1820-1840\end{array}$} \\
\hline & $\mathrm{N}$ & $\%$ & $\mathrm{~N}$ & $\%$ \\
\hline \multicolumn{5}{|c|}{ Softlong $\bar{e}$} \\
\hline$<\mathrm{e}>$ & 1,664 & 59.5 & 3,043 & 92.5 \\
\hline$<\mathrm{ee}>$ & 1,133 & 40.5 & 246 & 7.5 \\
\hline \multicolumn{5}{|c|}{ Sharplong $\hat{e}$} \\
\hline$<\mathrm{e}>$ & 150 & 9.9 & 167 & 8.5 \\
\hline$<e e>$ & 1,364 & 90.1 & 1,806 & 91.5 \\
\hline
\end{tabular}


case in period 1 and remains the same in period 2. A great change, however, can be seen in the case of the softlong variant. Whereas the eighteenth-century results show a modest preference of $59.5 \%$ for $<\mathrm{e}\rangle$, which is the preferred variant in the phonology-based system, the share of $<\mathrm{e}>$ increases to $92.5 \%$ in period 2 . The result is a neat distribution of $<\mathrm{e}>$ and $<\mathrm{ee}>$ in conformity with the Siegenbeek system.

In addition to this remarkable change in the direction of the officially prescribed forms, Krogull (2018) shows that there seems to be a regional effect. In particular, the historical phonology-based system, though not fully established, is already visible in Zeeland and Groningen in the eighteenth century. In most other regions, <e> and $<$ ee $>$ are distributed over softlong contexts in an apparently random way in the eighteenth century, giving way to the dominance of $<\mathrm{e}>$ in the nineteenth century. An equal distribution at chance level clearly suggests a merger in the spoken language, whereas the preference for $<\mathrm{e}>$ in Zeeland and Groningen confirms the maintenance of the original difference in the spoken language. Irrespectively of the spoken language, however, the etymological difference is represented throughout the language area in the nineteenth century, as advocated by Siegenbeek.

\subsubsection{Consonants}

The first consonantal variable that we focus on is the representation of / xt/ in syllable-final position. Dutch has a voiced and an unvoiced velar fricative, ${ }^{2}$ which are orthographically distinguished in initial position: compare gaan 'go' with intial $/ \gamma /$ spelled $<\mathrm{g}>$, and chaos 'chaos' with initial $/ \mathrm{x} /$ spelled $<\mathrm{ch}>$. Since Dutch has final devoicing, the difference is not present in final position. This means that words with a velar fricative in final position that are derived from a form with the voiced variant, can adopt both orthographic variants, $<$ ch $>$ representing the actual voiceless pronunciation, and $<\mathrm{g}>$ representing the morphology of the word. This applies to words with the velar fricative in final position, such as the singular present tense form vraag 'ask' from vragen 'ask', as well as to the combination of the velar fricative with / $\mathrm{t} /$, for example klacht or klagt 'complaint', derived from klagen 'complain'. In this section, we focus on this combination.

As in many other cases, Siegenbeek's (1804a) rule for the spelling of the syllable-final /xt/ cluster strongly depends on historical and etymological considerations. He proposes a division into words spelled $<$ cht $>$ and words spelled $<$ gt $>$ mainly on etymological and/or morphological grounds (1804a: 163), for example klagt 'complaint' should take $<$ gt $>$ as it is derived from the verb klagen 'complain' with $<$ g $>$. In our analyses, we will refer to these type of words as $\langle$ gt $>$ words.

2. The place of the articulation is highly variable ranging from uvular to palatal. We use velar as a cover term. 
Following Siegenbeek, these are opposed to what we will call $<$ cht $>$ words, that is words spelled $<\mathrm{cht}>$ for phonetic reasons such as acht 'eight'. Thus, the basic line of reasoning according to Siegenbeek is as follows: use the grapheme $<\mathrm{cht}>$ in final position to signal final devoicing, unless there is an etymological or morphological reason to adopt $\langle\mathrm{gt}>$.

Siegenbeek (1804a: 162) also mentions the historically present variant < ght $>$, which was another orthographic effort to distinguish the devoiced fricative from the voiced variant. Siegenbeek calls $<$ ght $>$ an inappropriate variant, not in accordance with the nature of the language. In fact, Moonen (1706: 8-9) is the only eighteenth-century commentator who acknowledged all three variants, viz. $<\mathrm{gt}>$, $<$ ght $>$ and $<$ cht $>$. All other eighteenth-century commentators focused only on $<$ gt $>$ and $<$ cht $>$, considering $<$ ght $>$ an old-fashioned variant to be avoided.

In the metalinguistic discussions preceding Siegenbeek (1804a), the two main arguments concerned the possibly diverging principles that have already been mentioned: on the one hand, the phonetic principle, particularly final devoicing, and on the other hand, the etymological principle and in particular the need to represent morphological relationships in the spelling. A third important issue in the eighteenth-century discussions was the need to distinguish homonyms such as acht 'eight' and acht 'care, attention'. Whereas both lack an etymological or morphological reason to spell agt, many commentators nevertheless proposed separating these homonyms orthographically, for example by prescribing agt 'eight' instead of acht. Following Kluit (1777: 24-25), Siegenbeek (1804a: 197-198) rejected the need to distinguish such homonyms by a division of labour between $<$ gt $>$ and $<$ cht $>$.

When exploring the GDC, we soon found that three variants were in use: $<$ cht $>$, $<$ gt $>$ as well as $<$ ght $>$. As said, we distinguish between $<$ cht $>$ words and $<$ gt $>$ words following Siegenbeek's prescriptions, that is, between words where Siegenbeek prescribed $<$ cht $>$ and words where he prescribed $\langle\mathrm{gt}\rangle$. For both categories, we established the ten most frequent sets of lexemes. In the category of $<\mathrm{cht}>$ words, these were acht, wacht, echt, dacht, slecht, nacht, dochter, nicht, zocht and kocht. In the category of <gt> words, these were regt, zigt, bragt, rigt, mogt, magt, jagt, pligt, togt and vlugt. In fact, these lexemes should be considered lexical search strings, which means that the set wacht, for example, comprises the verbs wachten 'wait' and verwachten 'expect' as well as derivations such as verwachting 'expectation' and onverwachts 'unexpected' and compounds such as erewacht 'guard of honour' - and all these words with the variants $\langle$ cht $>$, $<$ gt $>$ and $<$ ght $>$.

The corpus search generated 4,957 tokens for both categories in both periods (between 1,000 and 1,400 tokens within each category per period). Table 3 presents the distribution of the three variants in so-called $<$ cht $>$ words, per period. Likewise, Table 4 presents the diachronic distribution of the three variants in $\langle\mathrm{gt}\rangle$ words. 
Table 3. Diachronic distribution of the spelling of $<$ cht $>$ words in the GDC

\begin{tabular}{lcccc}
\hline & Period 1 & \multicolumn{3}{c}{ Period 2 } \\
& $\mathbf{1 7 7 0 - 1 7 9 0}$ & \multicolumn{1}{l}{$\mathbf{1 8 2 0 - 1 8 4 0}$} \\
\hline & $\mathrm{N}$ & $\%$ & $\mathrm{~N}$ & $\%$ \\
\hline$<$ cht $>$ & 241 & 17.5 & 987 & 75.7 \\
$<$ gt $>$ & 1,117 & 80.9 & 316 & 24.3 \\
$<$ ght $>$ & 23 & 1.7 & 0 & 0 \\
Total & 1,381 & 100 & $\mathbf{1 , 3 0 3}$ & $\mathbf{1 0 0}$ \\
\hline
\end{tabular}

Table 4. Diachronic distribution of the spelling of $<\mathrm{gt}>$ words in the GDC

\begin{tabular}{lcccc}
\hline & $\begin{array}{l}\text { Period 1 } \\
\mathbf{1 7 7 0 - 1 7 9 0}\end{array}$ & \multicolumn{3}{c}{$\begin{array}{l}\text { Period 2 } \\
\mathbf{1 8 2 0 - 1 8 4 0}\end{array}$} \\
\hline & $\mathrm{N}$ & $\%$ & $\mathrm{~N}$ & $\%$ \\
\hline$<$ cht $>$ & 217 & 20.3 & 213 & 17.5 \\
$<$ gt $>$ & 838 & 78.5 & 992 & 82.3 \\
$<$ ght $>$ & 13 & 1.2 & 0 & 0 \\
Total & $\mathbf{1 , 0 6 8}$ & $\mathbf{1 0 0}$ & $\mathbf{1 , 2 0 5}$ & $\mathbf{1 0 0}$ \\
\hline
\end{tabular}

Tables 3 and 4 clearly show that in period 1, both categories of words display a completely similar distribution despite the fact that etymological and morphological aspects had been part of the eighteenth-century metalinguistic tradition. In other words, those metalinguistic considerations appear to be irrelevant in period 1 . The dominant variant in both categories is $<\mathrm{gt}>$ with a share of c. $80 \%$.

In period 2, the situation is different. Whereas $<\mathrm{gt}>$ is still the main variant with c. $80 \%$ in the category of $<$ gt $>$ words, there is a radical change in the category of $<$ cht $>$ words, where $<$ cht $>$ now makes up $75.7 \%$ of the results. This means that a homogenously treated group of words with final /xt/ is successfully split into two orthographically distinct groups on non-phonetic grounds, i.e. for etymological and/or morphological reasons.

As to the third variant, $<$ ght $>$ occurs only marginally (36 tokens) in period 1 , and is absent in period 2. A closer inspection of the data reveals that $<$ ght $>$ is a manuscript variant in period 1 and does not occur in newspapers. We will ignore $<$ ght $>$ in the discussion below.

Furthermore, the variable genre has a strong effect on the distribution. Tables 5 and 6 present the diachronic distribution for $<$ cht $>$ words and $<\mathrm{gt}>$ words, respectively.

In both categories, $<\mathrm{gt}>$ is the main variant in period 1, particularly in letters with $87.8 \%$ but also in diaries and newspapers, which pattern similarly with $70-80 \%$ $<$ gt $>$. In period 2, there is an almost complete shift to $<$ cht $>$ in $<$ cht $>$ words in 
Table 5. Diachronic distribution of the spelling of $<$ cht $>$ words in the GDC, across genre

\begin{tabular}{|c|c|c|c|c|c|c|c|}
\hline & & \multicolumn{3}{|c|}{$\begin{array}{l}\text { Period } 1 \\
1770-1790\end{array}$} & \multicolumn{3}{|c|}{$\begin{array}{l}\text { Period } 2 \\
1820-1840\end{array}$} \\
\hline & & Letters & Diaries & Newspapers & Letters & Diaries & Newspapers \\
\hline \multirow[t]{2}{*}{$<\mathrm{gt}>$} & $\mathrm{N}$ & 711 & 301 & 105 & 230 & 86 & 0 \\
\hline & $\%$ & 87.8 & 75.4 & 70.5 & 32.9 & 20.2 & 0 \\
\hline \multirow[t]{2}{*}{$<$ cht $>$} & $\mathrm{N}$ & 99 & 98 & 44 & 470 & 339 & 178 \\
\hline & $\%$ & 12.2 & 24.6 & 29.5 & 67.1 & 79.8 & 100 \\
\hline Total & $\mathrm{N}$ & 810 & 399 & 149 & 700 & 425 & 178 \\
\hline
\end{tabular}

Table 6. Diachronic distribution of the spelling of $<\mathrm{gt}>$ words in the GDC, across genre

\begin{tabular}{|c|c|c|c|c|c|c|c|}
\hline & & \multicolumn{3}{|c|}{$\begin{array}{l}\text { Period } 1 \\
1770-1790\end{array}$} & \multicolumn{3}{|c|}{$\begin{array}{l}\text { Period } 2 \\
1820-1840\end{array}$} \\
\hline & & Letters & Diaries & Newspapers & Letters & Diaries & Newspapers \\
\hline \multirow[t]{2}{*}{$<\mathrm{gt}>$} & $\mathrm{N}$ & 338 & 313 & 187 & 363 & 314 & 315 \\
\hline & $\%$ & 89.4 & 70.2 & 81.0 & 80.5 & 72.2 & 98.7 \\
\hline \multirow[t]{2}{*}{$<$ cht $>$} & $\mathrm{N}$ & 40 & 133 & 44 & 88 & 121 & 4 \\
\hline & $\%$ & 10.6 & 29.8 & 19.0 & 19.5 & 27.8 & 1.3 \\
\hline Total & $\mathrm{N}$ & 378 & 446 & 231 & 451 & 435 & 319 \\
\hline
\end{tabular}

newspapers, less so in diaries (79.8\%), and even less so in letters $(67.1 \%)$, where there is nevertheless a considerable shift from $12.2 \%<$ cht $>$ to two-thirds $<$ cht $>$. In $<\mathrm{gt}>$ words, letters maintain $<\mathrm{gt}>$ as the dominant variant though with a slight decrease, diaries are stable with just over $70 \%<$ gt $>$, and newspapers adopt $<$ gt $>$ even more strongly and in fact almost 100\%. From Siegenbeek's perspective, this shift is impressive, particularly in the newspapers. Ego-documents, however, both private letters and diaries, maintain 20 to $35 \%$ proscribed variants in period 2 .

Zooming in the ego-documents, and particularly on the gender of the writers gives the results presented in Tables 7 and 8 .

In period $1,<\mathrm{gt}>$ is the main variant for both genders, though even more so for women, who show less variation, producing hardly any tokens of $<$ cht $>$. The shift to $<$ cht $>$ in period 2 is particularly visible with male writers. Female writers also switch to predominantly $<$ cht $>$ in $<$ cht $>$ words, but they seem to lag behind with $39.2 \%<\mathrm{gt}>$.

In the case of $<\mathrm{gt}>$ words, men are stable with three-quarters $<\mathrm{gt}>$ in both periods 1 and 2 . Women, coming from $97.2 \%<\mathrm{gt}>$, show a remarkable decrease to $79.6 \%<$ gt $>$, so that $<$ cht $>$ increases from nearly absent to $20.4 \%$. Since women come from a situation with an almost uniform use of $\langle$ gt $>$, viz. $88.7 \%$ in $<$ cht $>$ 
Table 7. Diachronic distribution of the spelling of $<$ cht $>$ words in the GDC, across gender

\begin{tabular}{|c|c|c|c|c|c|}
\hline & & \multicolumn{2}{|c|}{$\begin{array}{l}\text { Period } 1 \\
1770-1790\end{array}$} & \multicolumn{2}{|c|}{$\begin{array}{l}\text { Period } 2 \\
1820-1840\end{array}$} \\
\hline & & Men & Women & Men & Women \\
\hline \multirow[t]{2}{*}{$<\mathrm{gt}>$} & $\mathrm{N}$ & 707 & 305 & 132 & 184 \\
\hline & $\%$ & 81.7 & 88.7 & 20.1 & 39.2 \\
\hline \multirow[t]{2}{*}{$<$ cht $>$} & $\mathrm{N}$ & 158 & 39 & 524 & 285 \\
\hline & $\%$ & 18.3 & 11.3 & 79.9 & 60.8 \\
\hline Total & $\mathrm{N}$ & 865 & 344 & 656 & 469 \\
\hline
\end{tabular}

Table 8. Diachronic distribution of the spelling of $<\mathrm{gt}>$ words in the GDC, across gender

\begin{tabular}{|c|c|c|c|c|c|}
\hline & & \multicolumn{2}{|c|}{$\begin{array}{l}\text { Period } 1 \\
1770-1790\end{array}$} & \multicolumn{2}{|c|}{$\begin{array}{l}\text { Period } 2 \\
1820-1840\end{array}$} \\
\hline & & Men & Women & Men & Women \\
\hline \multirow[t]{2}{*}{$<\mathrm{gt}>$} & $\mathrm{N}$ & 476 & 175 & 412 & 265 \\
\hline & $\%$ & 73.9 & 97.2 & 75.5 & 79.6 \\
\hline \multirow[t]{2}{*}{$<$ cht $>$} & $\mathrm{N}$ & 168 & 5 & 134 & 68 \\
\hline & $\%$ & 26.1 & 2.7 & 24.5 & 20.4 \\
\hline Total & $\mathrm{N}$ & 644 & 180 & 546 & 333 \\
\hline
\end{tabular}

words and $97.2 \%$ in $<$ gt $>$ words, i.e. $91.6 \%$ overall in period 1 , the rise of $<$ cht $>$ spellings in $<\mathrm{gt}>$ words may count as evidence that there was quite some awareness of the newly proclaimed prescriptions. In fact, we may be witnessing instances of hypercorrection. In any case, women's orthography becomes more variable over time, incorporating $<\mathrm{cht}>$ along with $<\mathrm{gt}>$, in line with Siegenbeek's prescription to use both $<$ cht $>$ and $<$ gt $>$ for the representation of final /xt/, depending on the etymology and/or morphology.

The second variable from the field of consonants is the ending of second and third person singular and second person plural present indicative forms of verbs with a $d$-stem, e.g. modern Dutch zij antwoordt 'she answers' (see also Section 10.4). Three variants occur in the history of Dutch: $\langle\mathrm{d}\rangle,\langle\mathrm{t}\rangle,\langle\mathrm{dt}\rangle$. These are also the three variants that occur in the GDC. The variant $<\mathrm{d}>$ is analogous to other forms, where /d/ can be heard, such as the infinitive and the plural forms (antwoorden). The variant $<\mathrm{t}\rangle$ represents the pronunciation as Dutch has final devoicing. Since the ending of second and third person singular and second person plural present indicative forms of verbs with a others stems are formed by adding $<\mathrm{t}>$ to the stem, e.g. $z i j$ loopt $<$ loop $+t$ 'she walks', the variant $<\mathrm{dt}>$ extends this system to $d$-stems. Regardless of the spelling, the pronunciation is $/ \mathrm{t} /$. 
The eighteenth-century metalinguistic tradition generally prescribes $<\mathrm{dt}>$, though there are a few exceptions. This variant is mainly preferred on morphological grounds, i.e. it is an analogical spelling conforming to the stem $+<t>$ principle with other verbs. Some commentators invoke etymological arguments to argue for $<\mathrm{dt}>$. Siegenbeek (1804a: 156) also prescribed $<\mathrm{dt}>$, mainly for etymological reasons: following Huydecoper, Kluit and Weiland, he considered the ending $<\mathrm{dt}>$ to be a syncopated form of the original ending -det. Interestingly, there is general agreement that the orthographic combination $<\mathrm{dt}>$ is odd, malformed (Siegenbeek), disgusting, absurd (Kluit), yet necessary for morphological transparency and etymological reasons.

The variable has a particular metalinguistic history. In the southern Dutch metalinguistic tradition of the eighteenth and early nineteenth century, the variant $<\mathrm{dt}>$ was considered to be typically northern, whereas $<\mathrm{d}>$ was considered to be typically southern (Vosters \& Rutten 2015). This opposition has been shown to be too schematic, and not in line with writing practices (Vosters \& Rutten 2015; Vosters et al. 2010). As said, the northern Dutch normative tradition generally preferred $<\mathrm{dt}>$.

For our analysis of this variable in the GDC, relevant forms of fifteen frequent verbs were selected, taking into account variation such as $\langle\mathrm{s}\rangle \mid\langle\mathrm{z}\rangle$. The fifteen verbs were: worden, vinden, houden, melden, zouden, rijden, zenden, bieden, lijden, wenden, treden, antwoorden, raden, scheiden, bidden. The search generated 805 tokens, of which 363 in period 1 and 442 in period 2. Table 9 present the diachronic distribution of the three variants $\langle\mathrm{dt}\rangle,\langle\mathrm{d}\rangle$ and $<\mathrm{t}\rangle$.

Table 9. Diachronic distribution of the ending of second and third person singular and second person plural present indicative forms of $d$-stems in the GDC

\begin{tabular}{|c|c|c|c|c|}
\hline & \multicolumn{2}{|c|}{$\begin{array}{l}\text { Period } 1 \\
1770-1790\end{array}$} & \multicolumn{2}{|c|}{$\begin{array}{l}\text { Period } 2 \\
1820-1840\end{array}$} \\
\hline & $\mathrm{N}$ & $\%$ & $\mathrm{~N}$ & $\%$ \\
\hline$<\mathrm{dt}>$ & 62 & 17.1 & 293 & 66.3 \\
\hline$<\mathrm{d}>$ & 258 & 71.1 & 138 & 31.2 \\
\hline$<t>$ & 43 & 11.8 & 11 & 2.5 \\
\hline Total & 363 & 100 & 442 & 100 \\
\hline
\end{tabular}

In sharp contrast to the eighteenth-century metalinguistic tradition in the north, $<\mathrm{d}>$ is the majority form in period 1 with a share of $71.1 \%$. This changes dramatically to $66.3 \%<\mathrm{dt}>$ in period 2 . This suggests a clear effect of Siegenbeek's prescription. There was already the prescriptive preference for $\langle\mathrm{dt}\rangle$, so the radical shift to $<\mathrm{dt}>$ can only be a direct effect of the completely new sociolinguistic situation 
with an explicit and official top-down language policy. Nevertheless, $<\mathrm{d}>$ remains an important variant with $31.2 \%$ in period 2 , and even $<\mathrm{t}>$ still occurs, albeit even less than in period 1.

Again, splitting up the results across genre provides evidence of the importance of genre as a conditioning factor; see Table 10 .

Table 10. Diachronic distribution of the ending of second and third person singular and second person plural present indicative forms of $d$-stems in the GDC, across genre

\begin{tabular}{|c|c|c|c|c|c|c|c|}
\hline & & \multicolumn{3}{|c|}{$\begin{array}{l}\text { Period } 1 \\
1770-1790\end{array}$} & \multicolumn{3}{|c|}{$\begin{array}{l}\text { Period } 2 \\
1820-1840\end{array}$} \\
\hline & & Letters & Diaries & Newspapers & Letters & Diaries & Newspapers \\
\hline \multirow[t]{2}{*}{$<\mathrm{dt}>$} & $\mathrm{N}$ & 34 & 15 & 13 & 133 & 72 & 88 \\
\hline & $\%$ & 18.8 & 14.7 & 16.3 & 56.8 & 61.5 & 96.7 \\
\hline \multirow[t]{2}{*}{$<\mathrm{d}>$} & $\mathrm{N}$ & 108 & 83 & 67 & 91 & 44 & 3 \\
\hline & $\%$ & 59.7 & 81.4 & 83.8 & 38.9 & 37.6 & 3.3 \\
\hline \multirow[t]{2}{*}{$<\mathrm{t}>$} & $\mathrm{N}$ & 39 & 4 & 0 & 10 & 1 & 0 \\
\hline & $\%$ & 21.5 & 3.9 & 0 & 4.3 & 0.9 & 0 \\
\hline Total & $\mathrm{N}$ & 181 & 102 & 80 & 234 & 117 & 91 \\
\hline
\end{tabular}

The results across genre show that $<\mathrm{dt}>$ was far from an important variant in period 1 , with proportions ranging from 14.7 to $18.8 \%$. The dominant variant in all genres was $<\mathrm{d}>$, while particularly in letters, $<\mathrm{t}>$ was also still in use. In period 2 , the change in newspapers is again dramatic, with $96.7 \%<\mathrm{dt}>$. In the ego-documents, the shift towards the prescribed form is less strong, though clearly visible. The variant $<\mathrm{d}>$ maintains a share of just under $40 \%$, however. The third variant becomes marginal.

Krogull (2018) also analyses the diachronic distribution of $\langle\mathrm{d}\rangle,\langle\mathrm{t}\rangle$ and $\langle\mathrm{dt}\rangle$ across region. It turns out that there is only one region that diverges from the general pattern that $<\mathrm{d}>$ dominates in period 1 . Only in North Holland, is $<\mathrm{dt}>$ already the main variant in period 1 with a share of $47.7 \%$, chiefly due to the use of $<\mathrm{dt}>$ in newspapers from this region. In addition, there are only two regions where $<\mathrm{d}>$ is responsible for more than $80 \%$ of the tokens, viz. the two southernmost regions in the GDC: North Brabant and Zeeland. Intriguing is the finding that $<\mathrm{d}>$ is relatively important in the south. This seems to confirm a general tendency for $<\mathrm{d}>$ to be more prevalent in the south, although the south should then be extended to include the southern parts of the Northern Netherlands, and should not be limited to Flanders. In period 2, there is only one region left where $<\mathrm{d}>$ is still a main variant, viz. North Brabant with $49.4 \%<\mathrm{d}>$ as well as $49.4 \%<\mathrm{dt}>$. 


\subsection{Morphosyntax}

Contrary to the orthographic phenomena discussed in 11.3, direct influence of the official codification of the language on usage patterns is less visible in the case of morphosyntactic variables. In Section 11.4.1, we will focus on the genitive case. Section 11.4.2 discusses relativisation. In both cases, genre is an important factor conditioning the variation.

\subsubsection{The genitive}

As explained in Section 4.5, nominal inflection was a key concern in the Dutch metalinguistic tradition. Two opposite developments created a deep divide between Early and Late Modern language use and metalanguage. Loss of inflectional suffixes led to the deterioration of the inherited system with three nominal genders and four cases, resulting in a two-gender system with inflectional marking being largely restricted to the personal pronouns. This development set in already in the Middle Dutch period. Dutch metalanguage from the sixteenth century onwards, however, promoted three genders and up to six nominal cases. At the same time, prepositional constructions expressing functions that could also be expressed by, for example, the genitive case, were discussed in metalinguistic discourse. In general terms, we can say that language use veered towards analytic constructions with prepositions such as van 'from', whereas the metalinguistic tradition preferred the historical synthetic forms. After some observable tolerance towards analytic alternatives in the second half of the eighteenth century, Weiland's official grammar (1805a) reinstalled the synthetic variants as the preferred variants.

In the case of the genitive, the situation comprised synthetic forms such as des in the masculine and neuter singular, and der in the feminine singular and in the plural of all genders. These variants competed with the analytic alternatives van de 'of the' in the plural and in the feminine singular, van de or van den 'of the' in the masculine singular, and van het 'of the' in the neuter singular. Likewise, the range of indefinite articles in genitival position comprised eens and eener 'of a' as opposed to van een and van eene ( $n$ ) 'of a'. Similar pairs of synthetic and analytic forms existed in the case of demonstrative and possessive pronouns, e.g. mijns-van mijn 'of my', dezer-van deze 'of this, of these'.

Weiland (1805a) preferred the synthetic variants, although he himself did not use the synthetic variants exclusively, nor did he provide clear rules for when to use the synthetic genitive, or explain in which contexts he considered the analytic alternatives to be acceptable. The question we are concerned with here is whether Weiland's preference for the synthetic variants, i.e. for the historical genitive forms, 
resulted in an increase of such forms in actual language use. To investigate this, genitival constructions were extracted from the GDC: both historical synthetic forms and analytic alternatives with the preposition van. We focused on definite and indefinite articles (de 'the', het 'the', een 'a'), demonstrative pronouns (deze 'this', dit 'this', die 'that') and possessive pronouns (mijn 'my', ons 'our', zijn 'his', haar 'her', hun 'their', $u w$ 'your'), taking into account spelling variation. More information on the procedure followed can be found in Krogull (2018). Some corpus examples are provided in (1)-(4). Examples (1) and (3) illustrate the use of the historical synthetic forms (der, zijner), examples (2) and (4) the use of analytic alternatives (van de, van zijne).

(1) de andere zyde der stad the other side of-the city

(2) in het midden van de kerk in the middle of the church

(3) het verlies zijner vloot the loss of-his fleet

(4) het overlijden van zijne gemalin the passing of his wife

The corpus search resulted in 4,762 tokens of genitival constructions, distributed across the two options (synthetic and alternative) and the two periods as shown in Table 11.

Table 11. Diachronic distribution of genitival constructions in the GDC

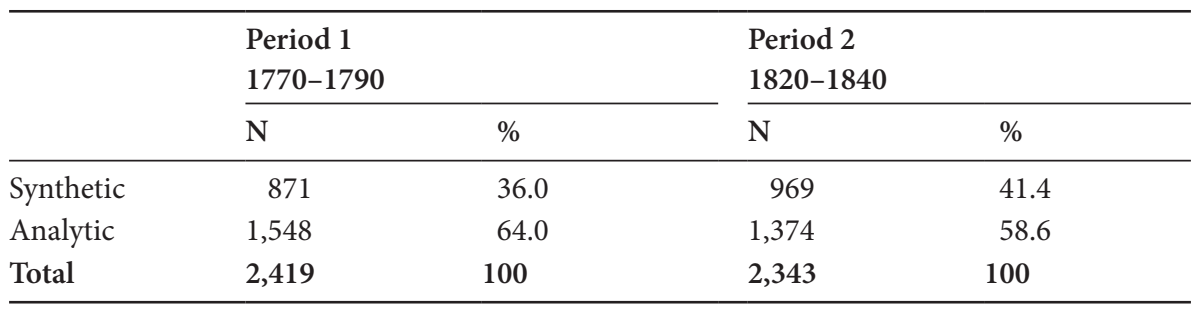

As can be seen in Table 11, the distribution of synthetic and analytic variants remains relatively stable. There is no sudden increase of the synthetic variants, in contrast to the orthographic cases discussed earlier, where period 2 witnessed a remarkable increase in the prescribed variants.

Krogull (2018) discusses a range of internal and external factors conditioning the variation of synthetic and analytic genitival constructions. One crucial external factor turns out to be genre. Table 12 presents the distribution of synthetic and analytic genitival constructions across genre and period. 
Table 12. Diachronic distribution of genitival constructions in the GDC, across genre

\begin{tabular}{|c|c|c|c|c|c|c|c|}
\hline & & \multicolumn{3}{|c|}{$\begin{array}{l}\text { Period } 1 \\
1770-1790\end{array}$} & \multicolumn{3}{|c|}{$\begin{array}{l}\text { Period } 2 \\
1820-1840\end{array}$} \\
\hline & & Letters & Diaries & Newspapers & Letters & Diaries & Newspapers \\
\hline \multirow[t]{2}{*}{ Synthetic } & $\mathrm{N}$ & 263 & 201 & 407 & 205 & 269 & 495 \\
\hline & $\%$ & 36.2 & 25.2 & 45.5 & 30.1 & 39.4 & 50.6 \\
\hline \multirow[t]{2}{*}{ Analytic } & $\mathrm{N}$ & 463 & 597 & 488 & 477 & 414 & 483 \\
\hline & $\%$ & 63.8 & 74.8 & 54.5 & 69.9 & 60.6 & 49.4 \\
\hline Total & $\mathrm{N}$ & 726 & 798 & 895 & 682 & 683 & 978 \\
\hline
\end{tabular}

In the first period, synthetic genitives take up a quarter to a third of the total number of genitival constructions in ego-documents. They are slightly more frequent in letters, which Krogull (2018) shows to be largely due to formulaic expressions such as den 28 dezer 'the 28 th of this' (maand 'month' is often omitted) and onder het schrÿven dezes 'during the writing of this' (brief 'letter' omitted). In newspapers, synthetic and analytic alternatives are distributed almost equally. This remains the same in period 2. In ego-documents, however, there is a decrease in synthetic genitives in letters, yet an increase in diaries, where they take up $39.2 \%$ in period 2. Cross-tabulating genre and gender, Krogull (2018) shows that the increase in synthetic genitives in diaries is mostly due to male writers increasing their use of the historical option. While the proportions remain relatively stable in the most formal genre, i.e. in the newspapers, the increase of synthetic genitives in diaries could signal an awareness of these forms being preferred in writing. A similar development took place in the case of relative clauses, which we discuss in the next section.

\subsubsection{Relativisation}

The relativisation systems in the Germanic languages have been in heavy flux throughout the centuries, which renders them interesting topics for historical sociolinguists (see e.g. Romaine 2009 [1982]; Bergs 2005; Nevalainen \& Raumolin-Brunberg 2003; Negele 2012). In the case of Dutch, the most extensive historical-sociolinguistic analyses are reported in Rutten \& van der Wal (2014: Chapter 8). They focus on the change from so-called $d$ - to $w$-forms in the case of relative adverbs, for example from daar to waar in phrases such as de plaats daar > de plaats waar 'the place where'. This change also affects so-called relative pronominal adverbs, consisting of a relative adverb and a preposition, for example daarin 'therein' > waarin 'wherein' in examples such as het huis daarin > het huis waarin 'the house wherein, in which'. 
Similar changes occur in the system of Dutch relative pronouns. Given the complexity of the issue, with different forms for the neuter, masculine and feminine pronouns, and with partially, though not obligatory paradigmatic overlap with the adverbial forms in genitive and dative positions, we restrict our analysis here to the neuter relative pronoun in subject and object position.

We can distinguish five dominant variants in the history of Dutch, viz dat 'that', wat 'what', hetgeen 'the yonder', welk 'which', hetwelk 'the which'. The oldest variant is dat, derived from the demonstrative form dat 'that', but wat already comes up from the Middle Dutch period onwards. This is the common change from $d$ - to $w$-, which also implies a change from an originally demonstrative form to the interrogative form wat 'what'. In addition, alternative forms occur also from the Middle Dutch period onwards, viz. welk 'which' and the extended form hetwelk 'the which'. In the late Middle Dutch period, another additional form develops: hetgeen 'the yonder', which was originally a demonstrative pronoun.

These are also the five variants that occur in the GDC; see the examples (5-9).

(5) het beelderige mooye mandje dat zy voor my gemaakt heeft the lovely beautiful basket that she for me made has 'the lovely beautiful basket that she has made for me'

(6) Ons rytuig wat wy om 8 Uur besteld hadden our coach what we at eight o'clock ordered had 'our coach that we had ordered at eigh o'clock'

(7) het gure en regenachtig weder, het geen reeds den geheelen the biting and rainy weather the-yonder already the whole dag had geduurd

day had lasted

'the biting and rainy weather which had already lasted the whole day'

(8) het geheim welk 'er gaande was the secret which there happening was 'the secret that was happening there'

(9) het schoon gezicht't welk men nog lang van deze zyde op the beautiful view the which one still long from this side of de stad' blyft genieten the city remains enjoying 'the beautiful view of the city that one keeps enjoying from this side for a long time' 
The Dutch metalinguistic tradition is relatively succinct with respect to relativisation. Weiland's (1805a) grammar differs from this tradition in that it provides a relatively elaborate discussion of the various forms as well as of the conditions under which these forms should be used. For example, according to Weiland, wat should be used only with free or headless relative constructions and in combination with al or alles 'all' as in alles wat 'all that'. Similarly, Weiland (1799) had argued that hetgeen should be restricted to free relatives.

As argued by Krogull, Rutten \& van der Wal (2017), Weiland's categorisation of the existing forms in accordance with different types of relative constructions largely corresponds to the distribution of the forms in the GDC. This means that Weiland's categorisation is basically descriptively adequate. However, the results from the GDC also show that actual usage is more variable than acknowledged by Weiland, with almost all variants occurring in almost all contexts. Both wat and hetgeen, for example, are not restricted to free relatives but occur in many more types of relative constructions. Moreover, the distribution across the various relative constructions is already present in the eighteenth-century part of the GDC, when the influence of Weiland (1805a) is obviously impossible. This means that, while descriptively surprisingly adequate, the prescriptive influence of Weiland can be ruled out.

In fact, the relative stability of the distribution of the neuter relative pronoun in subject and object position is one of the remarkable results in Krogull, Rutten \& van der Wal (2017); see Table 13 for a diachronic overview.

Table 13. Diachronic distribution of neuter relative pronouns in the GDC

\begin{tabular}{lcccc}
\hline & $\begin{array}{l}\text { Period 1 } \\
\text { 1770-1790 }\end{array}$ & \multicolumn{3}{c}{$\begin{array}{l}\text { Period 2 } \\
\mathbf{1 8 2 0 - 1 8 4 0}\end{array}$} \\
\hline dat & $\mathrm{N}$ & $\%$ & $\mathrm{~N}$ & $\%$ \\
wat & 177 & 32.9 & 134 & 28.5 \\
hetgeen & 77 & 14.3 & 80 & 17.0 \\
welk & 102 & 19.0 & 75 & 15.9 \\
hetwelk & 22 & 4.1 & 14 & 3.0 \\
Total & 160 & 29.7 & 168 & 35.7 \\
\hline
\end{tabular}

By and large, this remarkable stability is also attested for the external variables of region and gender. While there are some interesting changes through time (see also Krogull 2018), many of the results for period 1 are quite similar to those for period 2. 
In the context of the present discussion, there is one notable exception: the share of hetwelk, which also slightly increases in the general results presented in Table 13, increases among male writers from c. $30 \%$ to over $40 \%$. Interestingly, some eighteenth-century commentators had assigned forms such as hetwelk to more formal registers, while dat was often conceptualised as a neutral form. The indexical value of hetwelk as formal or solemn was repeated by Weiland in his official grammar of 1805. Examining the GDC for genre effects on the distribution of neuter relative pronouns leads to significant results in this respect; see Table 14 .

Table 14. Diachronic distribution of neuter relative pronouns in the GDC, across genre

\begin{tabular}{|c|c|c|c|c|c|c|c|}
\hline & & \multicolumn{3}{|c|}{$\begin{array}{l}\text { Period } 1 \\
1770-1790\end{array}$} & \multicolumn{3}{|c|}{$\begin{array}{l}\text { Period } 2 \\
1820-1840\end{array}$} \\
\hline & & Letters & Diaries & Newspapers & Letters & Diaries & Newspapers \\
\hline \multirow[t]{2}{*}{ dat } & $\mathrm{N}$ & 62 & 102 & 13 & 72 & 53 & 9 \\
\hline & $\%$ & 25.3 & 47.7 & 16.5 & 34.0 & 26.6 & 15.0 \\
\hline \multirow[t]{2}{*}{ wat } & $\mathrm{N}$ & 61 & 10 & 6 & 52 & 19 & 9 \\
\hline & $\%$ & 24.9 & 4.7 & 7.6 & 24.5 & 9.5 & 15.0 \\
\hline \multirow[t]{2}{*}{ hetgeen } & $\mathrm{N}$ & 51 & 32 & 19 & 46 & 20 & 9 \\
\hline & $\%$ & 20.8 & 15.0 & 24.1 & 21.7 & 10.1 & 15.0 \\
\hline \multirow[t]{2}{*}{ welk } & $\mathrm{N}$ & 4 & 7 & 11 & 8 & 6 & 0 \\
\hline & $\%$ & 16.3 & 3.3 & 13.9 & 3.8 & 3.0 & 0.0 \\
\hline \multirow[t]{2}{*}{ hetwelk } & $\mathrm{N}$ & 67 & 63 & 30 & 34 & 101 & 33 \\
\hline & $\%$ & 27.3 & 29.4 & 38.0 & 16.0 & 50.8 & 55.0 \\
\hline Total & $\mathbf{N}$ & 245 & 214 & 79 & 212 & 199 & 60 \\
\hline
\end{tabular}

The results in Table 14 show that diaries are quite similar to private letters in period 1, apart from the higher share of dat and the concomitantly lower share of wat in diaries. Newspapers in period 1, however, have far fewer tokens of dat and wat, and higher proportions of hetgeen and hetwelk. In period 2, dat becomes even more prevalent in letters, in which hetwelk is on the decline. Diaries behave very differently and become more similar to newspapers, with a high proportion of hetwelk, which outnumbers all other variants and represents more than $50 \%$ of the tokens.

The increase of hetwelk signals the indexical value of this form, which had also been signalled in eighteenth-century metalinguistic discourse. This could be an effect of Weiland (1805a) confirming the formal status of the form. The results suggest that while this formal status might already have been acknowledged in eighteenth-century newspapers, it also leads to a split in the language of ego-documents in the nineteenth century. In other words, if we have attested influence of metalinguistic discourse on the course of linguistic variants, it is a genre-specific, or even subgenre-specific influence. 


\subsection{Final remarks}

In this chapter, we have presented the results of a range of case studies of the influence of Siegenbeek (1804a) and Weiland (1805a) on language use, using the newly created Going Dutch Corpus. The three orthographic case studies were characteristic of Siegenbeek's approach as they all involved relatively complex rules that partly depended on historical, etymological argumentation. While in large parts of the northern Low Countries, including the Holland area, so-called softlong and sharplong e's had long merged, Siegenbeek (1804a) nevertheless continued the historical writing tradition that distinguished, for example, softlong leven with $<\mathrm{e}>$ from sharplong leeren with $<\mathrm{ee}>$. The results of our corpus search show that the nineteenth-century data largely conform to this prescription, contrary to the eighteenth-century data, signalling a sudden shift towards the official spelling norms. A similar change occurred in the cases of the cluster of velar fricatives and $/ t /$ in final position. Irrespective of the voiced or unvoiced quality of analogical forms, Dutch fricatives are devoiced in final position. Siegenbeek, however, introduced a complex norm according to which analogical forms determined the spelling of the cluster as either $<\mathrm{gt}>$ or $<\mathrm{cht}\rangle$, distinguishing klagt 'complaint' from recht 'right', despite the phonetic similarity of the final cluster. The noun klagt is related to the verb klagen 'complain' with a voiced fricative in the middle position, while no such analogy can be established for recht. Again, the diachronic results show a remarkable shift towards the prescribed forms. Similarly, the $<\mathrm{dt}>$ cluster in certain forms of $d$-stem verbs, for example $z i j$ wordt 'she becomes', showed a remarkable increase in the nineteenth century.

Normative influence is much less obvious in the case of the two morphosyntactic variables. Nominal inflection had been one of the most prominent topics in metalinguistic discourse for more than two centuries already, yet no significant increase of synthetic genitives at the expense of analytical constructions could be established. Likewise, the distribution of variants of the neuter relative pronoun in subject and object position was diachronically stable, particularly when compared to the great changes taking place in orthography.

As a multi-genre corpus, the GDC allowed us to investigate genre differences. It has become clear that print language in nineteenth-century newspapers followed the officialised language norms much more strongly than the language in ego-documents. In newspapers, a radical change to the prescribed forms can often be found, attesting to the enormous impact of the top-down language policy. At the same time, we established differing degrees of conformity with the newly proclaimed 'standard' in the two types of ego-document. There was a clear generic split with diaries conforming more strongly to newspaper conventions and to the national norms than private letters. This shows that language users were often 
aware of the new norms and also conformed with these norms in writing, even in ego-documents such as diaries, though less so in private letters.

In a few cases, we have also pointed out the influence of other external variables, such as gender and region. Focusing primarily on the effects of Siegenbeek (1804a) and Weiland (1805a) here, we refer the reader to Krogull (2018) for more detailed analyses of various internal and external factors.

We conclude that the patterns of language use reported on in this chapter suggest quite some awareness of the official norms among nineteenth-century language users, particularly though not exclusively in orthography. In this respect, we also conclude that the implementation of the officialised norms in writing practices was fairly successful. Contrary to the strong metalinguistic discourse favouring the general use of the newly devised standard, however, external factors such as genre conditioned the variation. 



\section{Standard language ideology in the Netherlands Themes and research directions}

The rise of nationalism, both cultural and political, in eighteenth- and nineteenth-century Europe was a fundamental socio-political and cultural change with far-reaching consequences even to the present day. It was a pan-European phenomenon, impressively charted in the recent volume edited by Leerssen (2018). The linguistic corollary of this change was the rise of standard language ideology, from Finland to Spain, and from Iceland to the Habsburg Empire. Amidst these international events, the case of Dutch in the northern Netherlands from c. 1750 to c. 1850 offers a unique example: after the rise of the ideology from the 1750 s onwards, the new discourse of one language - one nation was swiftly transformed into concrete policies aimed at the dissemination of the newly devised standard language across the entire population of the newly established Dutch nation-state. The primary target of standard language ideology in this period was the internal multiplicity of Dutches: a detestable state of alleged linguistic chaos in need of homogenisation. I hope the analysis of Dutch in the Netherlands offered in this volume, and the themes and research directions discussed in this concluding chapter, will not only be useful for similar historical-sociolinguistic analyses of standard language ideology in other European settings, but will also contribute to the much needed comparative analysis of the interplay of language and nation in postmedieval Europe (cf. Nevalainen \& Rutten 2012; Rutten, Vosters \& Vandenbussche 2014).

The central theme of this volume is standard language ideology in the Netherlands: its emergence in the eighteenth century, and its effects on metalanguage, language policy and language use in the eighteenth and nineteenth centuries. The historical event at the heart of this study is the so-called schrijftaalregeling 'written language regulation' of 1804 and 1805, which comprised the first officialised orthography and grammar of the Dutch language. In this concluding chapter, I aim to bring together the recurring topics of the present volume, the leitmotifs that are present in almost all chapters, either as a bubbling undercurrent or as a plainly visible argument. 


\section{Splitting the continuum}

Perhaps the most pervasive metalinguistic operation identifiable in the period under investigation is the splitting of the sociolinguistic continuum, running from the plurality of spoken base dialects to various supralocal writing traditions, into the two neatly separable categories of non-standard and standard Dutch. Awareness of variability is not a modern phenomenon, and throughout history such awareness has often led to the discursive construction of linguistic hierarchies. In the course of the eighteenth century, however, older notions of linguistic difference became overlaid by the rigid compartmentalisation into standard and non-standard by way of the linguistic reflection of the emerging cultural and political nationalism (Chapter 6). In line with the new view of the inhabitants of the Low Countries as the homogeneous Dutch nation with its specific culture, history and ethnic characteristics, language was singled out as one of the cultural attributes through which the enduring nation became manifest. Imbuing one specific variety of the Dutch language, that is one variety of one of the many languages used in the Low Countries at that time, with notions of standardness, normality and neutrality may perhaps count as an archetypal example of the iconisation processes characteristic of linguistic nationalism (Chapter 2).

Elevating one variety to the privileged position of the neutral standard language creates an inferior class to which non-neutral and non-standard forms and varieties are consigned. These comprise base dialects as well as regionally marked forms in supralocal language, spoken forms as well as written forms, loans as well as obsolete forms and 'street language' (Chapter 7). A complete inventory of this inferior class does not, however, exist. Eighteenth- and nineteenth-century metalinguistic discourse was strongly focused on the supposedly neutral variety, that is on written supralocal Dutch, and did not generally consider deviating forms, except in specific discussions of variant selection and reduction (Chapter 8), and in the lexicographical discussions of the time (Chapter 7). The period thus exhibits a far-reaching form of metalinguistic erasure.

In terms of sociolinguistic repertoires, the discursive split into non-standard and standard Dutch can be conceptualised as the emergence of diglossia from a previous period of diaglossia (Chapter 3 ). It should be stressed that the analysis of the sociolinguistic situation as diaglossic is based on research on language use, while diglossia still primarily refers to the metalinguistic make-up. It is through political action, language policy and educational policy that top-down efforts were taken to end the state of diaglossia through the imposition of the standard variety upon people who used non-standard forms in speech and writing. While this approach feeds on a diglossic conceptualisation of sociolinguistic space, its ultimate 
goal is not diglossia, but the expulsion of non-standardness, with monoglossia as the end result (Chapter 6).

The field of education played a major role in the political effort towards nationalisation of the language. Various language laws, including the establishment of a school inspection system were intended to guarantee the implementation of the national standard in language use (Chapter 10, see also below). While the success of the policy and its impact on language use depended on a set of variable conditions, it is clear that the almost uniform adoption of the official spelling in early-nineteenth-century newspapers, as opposed to the remaining variation in handwritten sources (Chapter 11), did create what could be called generic diglossia. The edited and published language of newspapers represented the officialised and standardised form of Dutch promoted by the government, at least, in any case, its orthography.

While the impact of standard language ideology on patterns of language use was largely restricted to spelling, the impact on metalinguistic practices of the split into standard and non-standard was overwhelming. Of course, the discursive split of the sociolinguistic continuum was also partly founded on previous metalinguistic discourse, in particular on the tradition of normative grammar (Chapter 4). In the nineteenth century, too, the study of the Dutch language was first and foremost the study of supralocal writing traditions and their histories (Chapters 5 and 8). Scholarly interest in regional varieties was only gradually emerging (Chapter 9). Importantly, the split of the continuum implied a scholarly split into standard language linguistics on the one hand, and incipient dialectology on the other (Chapter 10). While historical and comparative approaches would soon start to incorporate evidence of regional varieties, the distinction between dialect-oriented and standard language-oriented approaches has been formative in the development of the discipline of linguistics. The battle over standardness can be traced almost from year to year in the lexicographical debates from the middle of the eighteenth century, when a strikingly inclusive approach was adhered to, to the middle of the nineteenth century, when the sources of the lexicon of the national language were limited to postmedieval, supralocal, and preferably literary texts (Chapter 7).

It is clear that standard language ideology and all the metalinguistic and discursive work connected with it was very much the fruit of socio-economically and politically privileged people. It was a top-down movement, that greatly inspired the more middle-class Maatschappij tot Nut van 't Algemeen 'Society for the benefit of the common good' as well as the national government. In educational settings, however, there is limited evidence that school inspectors explicitly imposed standard language ideology on schoolteachers (Chapter 10). This raises the question of the vicissitudes of standard language ideology in later years. It is still very much present 
in Dutch society, arguably more strongly than in the period around 1800. It would be interesting to trace its gradual dissemination through society from the early 1800 s onwards. Such research would ideally connect this metalinguistic change with changes in language use, in particular with the processes of dialect loss and regiolectisation characterising the nineteenth, twentieth and twenty-first centuries.

\section{Authority and authenticity}

With its neutrality and proclaimed unmarkedness, the Dutch standard variety promoted around 1800 exemplified a discourse of anonymity (Chapter 6). There were two sides to this: one descriptive and the other educational. From a descriptive perspective, the standard was conceptualised as the supralocal written variety that had emerged historically - a variety used and understood across the language area fulfilling the role of a neutral tool of communication. While empirically contestable, this description fulfilled a political function as the coherence of the nation would gain from such a form of neutral monoglossia. On the educational side, the professed anonymity of the standard and its important function as the nationwide neutral tool of communication resulted in a clear educational duty, viz. to teach it to the people, in particular to children. This led to various educational acts, including the foundation of a national system of school inspection (Chapter 10).

Interestingly, the anonymous, neutral, supralocal variety of Dutch, largely founded on literary writing and the tradition of normative grammar, was also conceptualised as the mother tongue - not necessarily of individual speakers, but of the nation in its entirety. Nowhere, perhaps, was the symbolic fusion of the concepts of language and nation more mysterious than in the idea of a variety that was ideologically the mother tongue of an entire nation, despite the fact that it was clearly not the language that most inhabitants of the Low Countries learned from their family members and peers - which is why it had to be taught to them. Here, the idea of a national mother tongue connects with notions of authenticity. The conceptual fusion of language and nation is in itself an essentialising claim to authenticity.

Authenticity often depends on time depth, and essentialisation gains from historical anchoring. The neutral standard language promoted around 1800 had a long and venerable history. Looking back on the recent past, commentators in the nineteenth century hailed the late sixteenth and the seventeenth centuries as the period in which the Dutch had emerged as a Protestant nation and as a military and economic superpower. In this Golden Age, Dutch culture had blossomed in an unprecedented way, also resulting in the development of the national language (Chapter 5). The conceptual blend of language and nation could be located in a concrete place and time, viz. the larger Holland area in the late sixteenth century 
and the first half of the seventeenth century. As with the concept of the mother tongue, there was an undeniable division between ideology and language use. The empirical fact of language change between the Golden Age and the nineteenth century did not affect the symbolic uniformity of seventeenth-century literary and biblical writing on the one hand, and the officialised national standard of the early nineteenth century on the other hand.

This first type of authenticity, connected with the standard variety, was rooted in its historical origins, which had matured during the Golden Age. At that time, the language had come of age, and had developed into a symbolic representation of the nation, by virtue of which the standard had also acquired an aura of neutrality and anonymity. This first type of authenticity, while rooted in the past, was essentially oriented to the future, and it motivated the educational duty outlined above. The national language policy of the early 1800 s aimed to spread a variety that was both an anonymous tool for nationwide communication as well as the authentic means of expression of the nation in question. Thus, the linguistic homogenisation of the Dutch entailed the regional and social dissemination of the authentic national language.

However, metalinguistic discourse was more complex, and gave way to another concept of authenticity (Chapter 9). Particularly in the discussions about a new dictionary (see also Chapter 7), reference was made to regional lexical items as authentic elements of the Dutch language. This second type of authenticity, connected with non-standard language, was relatively limited. To most commentators, it only concerned the lexicon. In addition, it was not the counterpart of an anonymous standard variety. On the contrary, the lexical items involved were far from neutral, and instead highly localisable. Importantly, it was conceptualised as a receding kind of authenticity, as a hallmark of language forms on the verge of disappearing. As such, its directionality was opposite to that of standard authenticity.

The period in which the Dutch nation found its authentic means of communication, i.e. the anchoring point of the Golden Age, was walled in by two periods of alleged Frenchification (Chapter 5). Even if the actual prominence of French in the contemporary Dutch society is left open to debate, the critical reflection on the supposed love of French among members of the homogeneous Dutch nation does not only reveal the emergence of standard language ideology. It also demonstrates that at least to some language users in specific situations, French was a valuable choice. The French language was invested with ideological notions such as cosmopolitanism and internationalism. It does not seem far-fetched to hypothesise that the use of French was imbued with notions of anonymity, too, for example when French represented the neutral choice in multilingual networks.

This raises the question of language ideological alternatives. Standard language ideology may have been dominant from the late eighteenth century onwards, but 
actual multilingualism, both individual and societal, suggests a wider spectrum of language ideologies. In the course of the nineteenth century, the anti-French discourse was replaced by anti-German and anti-English discourses, again revealing the apparent value of these languages to 'authentic' speakers of Dutch. In addition, regional identities remained important throughout history, and became even more important in the late twentieth century, resulting in a growth of dialect literature, and advancing dialect codification. A detailed analysis of the broad range of language ideologies complementing - or even contesting - standard language ideology in the period of the Dutch nation state is much needed, including the historicisation of internationalism, multiculturalism, discourses of endangerment, dialect ideologies and the commodification of language.

\section{Agency}

Many of the themes in this volume concern discursive and ideological formations. Diglossia has been interpreted as a metadiscursive representation inspired by linguistic nationalism (Chapter 3). Changes in metalinguistic discourse, particularly in normative grammar, have been connected with sociopolitical and cultural changes such as the rise of nationalism (Chapter 4). Various language myths have been discussed as prominent metalinguistic perspectives of the sociolinguistic situation and its presumed history (Chapters 5 and 6). The discursive splitting of the sociolinguistic continuum into standard and non-standard was also at the heart of the development and renewal of linguistic disciplines. Lexicology and lexicography became nationalised (Chapter 7). The study of language remained largely restricted to the perceived standard (Chapter 8 ). Non-standard forms and varieties only played a minor role, and were more often subject to folklorisation than to academic interest (Chapter 9).

The issue of agency is explicitly present in Chapter 10, in which school inspectors are tracked on their ideological missions, and individual schoolteachers are also brought into focus. Chapter 11 addresses agency to some extent as it shifts attention to language use, focusing on groups of speakers, and to functionally defined genres. In previous chapters, agency has not been overtly thematised, but it may have become clear that the many examples of metalinguistic discourse presented in these chapters are related to a relatively limited group of historical actors, networks and institutions. The large majority of the actors involved were ministers, literary authors and university professors. They were male, and predominantly, though not exclusively, from the wider Holland/Utrecht area. They were members of learned societies such as the Maatschappij der Nederlandsche Letterkunde 'Society of Dutch Language and Literature'. Some of them took up a position in politics, while others 
became school inspectors. Often, these occupations, positions and memberships were combined, which means that suggestions and intentions could sometimes be implemented rapidly when one of these individuals rose to political power. A case in point was minister and professor van der Palm, who was responsible for the initial stages of the language and education policies around 1800. A prime example of the combination of many roles with cultural, social and political relevance is set by minister, professor, literary author and commentator, language observer, long-time president of the Maatschappij der Nederlandsche Letterkunde and school inspector Siegenbeek, author of the official 1804 spelling (Chapter 8).

The study of cultural nationalism offers a useful framework that captures the increasing interest in the indigenous languages and cultural products of Europe, literature included, and that makes the link with the political ideology of nationalism (Leerssen 2006, 2010). It analyses this interest as an elite phenomenon of networks of intellectuals. In the Dutch context, the recent volume by Honings, Rutten \& van Kaltmhout (2018) brings together a set of male actors from the southern and northern Low Countries engaged in cultural nationalism at the end of the eighteenth and the beginning of the nineteenth century.

The study of cultural nationalism rightly stresses its international character, and focuses on the transmission of ideas across international networks, thus connecting the broad macro-perspective of discourse and ideology with the micro-perspective of concrete historical actors (see SPIN and Leerssen 2018). An equally important question concerns the connection between the national elite, as the proponents of standard language ideology, and the rest of the nation. Which actors and networks were instrumental in the spread of SLI across the population, institutions and cultural fields? Referring back to Chapter 10, the question can perhaps be reframed as follows: when did SLI, at the beginning of the nineteenth century still very much an elite discourse, develop into a standard language culture, recognised, acknowledged, embraced and defended by large parts of the population? An important but difficult task of future research will be to uncover historical language ideologies 'from below', and to establish their relation to more easily accessible metadiscourse produced by intellectuals and policy makers.

\section{Implementation}

The major ideological transformations that take place and result in SLI as well as the policy measures founded on the new ideology raise the question of the extent to which discursive changes influenced educational practices and language use. Or from a policy perspective: were the policy measures effective? These issues relate to implementation as a crucial step in standardisation (Chapters 10 and 11). 
Implementation involves the promotion of the standard, and obviously feeds on the split of the sociolinguistic continuum outlined above. In addition to the aforementioned metalinguistic form of erasure, which excludes and removes certain linguistic forms from metalinguistic discourse, implementation may involve a drive to the expulsion of actual linguistic forms and varieties from spoken and written language use in the interest of linguistic homogenisation.

Implementation is a multi-layered phenomenon with relevance at the level of ideology, for the field of education, and for variation and change in language use. At the ideological level, the rise of SLI in the Low Countries in the period around 1800 is very clear. It was accompanied by an abundance of myth-making and other types of metalinguistic discourse, and it also gave rise to concrete policy in the fields of education and language planning. SLI spread across the networks of actors mentioned above. Important as this may be, it still only affected a minor part of the population.

In the field of education, evidence shows that SLI was spreading (Chapter 10). School inspectors acted in accordance with SLI, and used the recently officialised form of the Dutch language as a yardstick when visiting and judging schools and schoolteachers. SLI was unmistakably part of the repertoire of both inspectors and teachers. At the same time, it was also noted that the attention paid to matters of language seemed not to be overwhelming in nineteenth-century school inspection reports, suggesting that SLI was not necessarily a dominant theme among school inspectors. However, this should not lead to the conclusion that SLI was of little importance as positive evidence for alternative language ideologies is entirely lacking. When arguing that a flexible attitude towards variability, not completely in line with the metalinguistic split of the continuum, still characterised the early nineteenth century, this was done on the basis of the absence of multiple references to SLI, not on the basis of evidence for alternative ideologies.

The school inspectors of the early nineteenth century represented the first generation of a new professional group in society responsible for the implementation of SLI in educational settings. While subscribing to SLI and the policy emanating from it, they adopted a nuanced attitude in their daily routine. Obvious questions for future research are whether, and if so how, SLI became a more dominant theme in the school inspection system in more recent times, and whether the educational field generally developed from a flexible attitude towards variability to a more strict position echoing the split of the continuum. Another aspect of implementation relates to the diffusion of the official standard variety across individuals, social groups and networks, as well as genres and societal domains. The case studies in Chapter 11, based on the Going Dutch Corpus, show that newspapers from the first half of the nineteenth century adopted the official spelling to an extremely large extent. Similar results were obtained from the ego-documents, though they continued 
to show more variation than newspapers. These are intriguing results as many of the orthographic prescriptions by Siegenbeek (1804a) were based on etymology rather than on pronunciation. Morphosyntactic prescriptions were followed to a much lesser extent, which goes for both newspapers and ego-documents.

Particularly in the case of spelling, variant reduction was clearly visible, and the direction of change was generally towards the standard. This points to a wide-spread awareness of the officialised orthography, which was only partly due to education as school inspectors were probably more lenient than public discourse suggested. This would mean that the discursive splitting of the sociolinguistic continuum into standard and non-standard soon started spreading across the population, motivating individual language users to adopt the official spelling, including its many distinctions with a historical-phonological motivation but no foundation in pronunciation. The sociolinguistic space, in other words, was developing towards a state of diglossia, signalling a changing attitude among language users.

As education was perhaps only one out of a range of different factors, other grounds for language users to adopt the standard should be investigated. The general shift to Siegenbeekian spelling norms in newspapers provides a clue. A contributing factor may have been the shift towards Siegenbeek in published writing in general. While this is still merely an assumption, such a general shift would lead to readers having hardly any access to alternative forms. The general change towards the Siegenbeek norms in school materials from the early nineteenth century (Chapter 10) corroborates this assumption.

In the present-day Dutch standard language culture, morphosyntactic items are far from absent in metalinguistic discourse and in popular discussions about linguistic prescriptivism. On the contrary, variants such as the use of the object form hun 'them' in subject position, and the conjunction of the comparative prescribed dan 'than' instead of proscribed als 'as' - are among the items invoking the strongest reactions among language users. It would be interesting to find out when morphosyntax accompanied orthography in standard language debates, whether this began in metalinguistic discourse, or in policing practices by editors and schoolteachers, or whether it was a change from below, originating from language users who became aware of morphosyntactic variation and who developed normative attitudes towards it.

In this book, I have analysed the emergence of standard language ideology in the eighteenth century and its effects on metalanguage, language policy and language use in the eighteenth and nineteenth centuries. The era of the Dutch nation state is sometimes delineated so that it encompasses the period from 1770 to 1970 (Kloek \& Mijnhardt 2001: 219, 568). In the second half of the eighteenth century, pervasive social, cultural and political changes led to a new order that can be summarised in the adjective national. The foundational phase of national language 
planning was at the heart of this study, including the first efforts at implementation in the early nineteenth century. A broad analysis of the nation state as a demarcated historical phenomenon and of the concomitant language ideologies, policies and patterns of language use would have as one of its main research topics the change from standard language ideology as an elite discourse in the late eighteenth and early nineteenth centuries to standard language culture as a lived experience of the population at large in subsequent periods. 


\section{References}

Aanteekeningen, ter verbetering en uitbreiding der opmerkingen omtrent den Gelderschen tongval. 1840. Taalkundig Magazijn 3. 37-68.

Aantekeningen van M. Siegenbeek by de Nederduitsche spraakkunst van P. Weiland. Manuscript University Library Leiden, LTK 49.

Aarsleff, Hans. 1974. The tradition of Condillac: The problem of the origin of language in the eighteenth century and the debate in the Berlin Academy before Herder. In Dell Hymes (ed.), Studies in the history of linguistics. Traditions and paradigms, 93-156. Bloomington \& London: Indiana University Press.

Academische voorlezingen over de Nederduitsche tale en welsprekenheid van den hoog geleerden heer M. Siegenbeek. Gewoon hoog leeraar in dezelven aan s lands universiteit te Leyden. $A^{\circ}$ 1797 \& 1798. Manuscript University Library Leiden, BPL 3363.

Agha, Asif. 2003. The social life of cultural value. Language \& Communication 23. 231-273. https://doi.org/10.1016/S0271-5309(03)00012-0

Agha, Asif. 2005. Voice, footing, enregisterment. Journal of Linguistic Anthropology 15. 38-59. https://doi.org/10.1525/jlin.2005.15.1.38

Algemeene denkbeelden over het nationaal onderwijs. 1798. Amsterdam: S.n.

Altendorf, Ulrike. 2003. Estuary English. Levelling at the interface of RP and south-eastern British English. Tübingen: Gunter Narr Verlag.

Anderson, Benedict. 1983. Imagined communities. Reflections on the origin and spread of nationalism. London: Verso.

Anderwald, Lieselotte (ed.). 2012. Sprachmythen - Fiktion oder Wirklichkeit? Frankfurt am Main etc: Peter Lang. https://doi.org/10.3726/978-3-653-01235-4

Anderwald, Lieselotte. 2016. Language between description and prescription. Verbs and verb categories in nineteenth-century grammars of English. Oxford: Oxford University Press. https://doi.org/10.1093/acprof:oso/9780190270674.001.0001

Anonymus. 1766. Verhandeling over de vraage: hoe moet men het verstand, en het hart van een kind bestieren, om het, ten eenigen tyde, een nuttig en gelukkig mensch te doen worden? Verhandelingen uitgegeeven door de Hollandsche Maatschappye der Weetenschappen IX-II. $1-120$.

ANS = Algemene Nederlandse Spraakkunst, first edn. 1984 by G. Geerts, W. Haeseryn, J. de Rooij \& M. C. van den Toorn; second edn. 1997 by W. Haeseryn, K. Romijn, G. Geerts, J. de Rooij \& M. C. van den Toorn; third, online edn. 2002. E-ANS (electronic version of the second edition), see http://ans.ruhosting.nl/e-ans/

Armstrong, Nigel \& Ian McKenzie. 2013. Standardization, ideology and linguistics. Houndmills etc: Palgrave Macmillan. https://doi.org/10.1057/9781137284396

Auer, Anita. 2014. Nineteenth-century English. Norms and usage. In Gijsbert Rutten, Rik Vosters \& Wim Vandenbussche (eds.), Norms and usage in language history, 1600-1900. A sociolinguistic and comparative perspective, 151-169. Amsterdam \& Philadelphia: Benjamins. 
Auer, Peter. 2005. Europe's sociolinguistic unity, or: A typology of European dialect/standard constellations. In Nicole Delbecque, Johan Van der Auwera \& Dirk Geeraerts (eds.), Perspectives on variation: Sociolinguistic, historical, comparative, 7-42. Berlin: De Gruyter. https://doi.org/10.1515/9783110909579.7

Auer, Peter. 2011. Dialect vs. standard: A typology of scenarios in Europe. In Bernd Kortmann \& Johan van der Auwera (eds.), The languages and linguistics of Europe, 485-500. Berlin: De Gruyter. https://doi.org/10.1515/9783110220261.485

Ayres-Bennett, Wendy. 2014. From l'usage to le bon usage and back. Norms and usage in seventeenthcentury France. In Gijsbert Rutten, Rik Vosters \& Wim Vandenbussche (eds.), Norms and usage in language history, 1600-1900. A sociolinguistic and comparative perspective, 173-200. Amsterdam \& Philadelphia: Benjamins.

Ayres-Bennet, Wendy \& Magali Seijido. 2011. Les compilations raisonnées des Remarques et Observations sur la langue française. French Studies 65: 347-356.

https://doi.org/10.1093/fs/knro73

Ayres-Bennett, Wendy \& Magali Seijido (eds.). 2013. Bon usage et variation sociolinguistique. Perspectives diachroniques et traditions nationales. Lyon: ENS Éditions.

Baar-de Weerd, C. F. 2009. Uw sekse en de onze. Vrouwen en genootschappen in Nederland en in de ons omringende landen (1750-ca. 1810). Hilversum: Verloren.

Bakker, D. M. 1977. De grammatica in de negentiende eeuw. In D. M. Bakker \& G. R. W. Dibbets (eds.), Geschiedenis van de Nederlandse taalkunde, 113-160. Den Bosch: Malmberg.

Bakker, Frens \& Joep Kruijsen. 2007. Het Limburgs onder Napoleon. Achttien Limburgse en Rijnlandse dialectvertalingen van 'De verloren zoon' uit 1806-1807. Utrecht: Gopher.

Bancroft, Timothy \& David Hopkin (eds.). 2012. Folklore and nationalism in Europe during the long nineteenth century. Leiden: Brill.

Bauman, Richard \& Charles L. Briggs. 2003. Voices of modernity. Language ideologies and the politics of inequality. Cambridge: Cambridge University Press.

https://doi.org/10.1017/CBO9780511486647

Bauer, Laurie \& Peter Trudgill (eds.). 1998. Language myths. London etc: Penguin.

Beal, Joan. 2004. English in modern times, 1700-1945. London: Hodder Arnold.

Beal, Joan. 2009. Enregisterment, commodification, and historical context: 'Geordie' versus

'Sheffieldish'. American Speech 84. 138-156. https://doi.org/10.1215/00031283-2009-012

Beets, Nicolaas. 1840. Noordhollandsch taaleigen. Taalkundig Magazijn 3. 510-515.

Beets, Nicolaas. 1842. Noordhollandsch taaleigen (tweede bijdrage). Taalkundig Magazijn 4. 365-371.

Behrns, J. H. 1840. Over de Twentsche vocalen en klankwijzigingen. Taalkundig Magazijn 3. 329-390.

Belgisch Museum voor de Nederduitsche tael-en letterkunde en de geschiedenis des vaderlands. 1837-1946. Vol. 1-10. Ed. by J. F. Willems. Ghent: F. en E. Gyselynck.

Bell, David A. 2016. Revolutionary France and the Origins of Nationalism. An Old Problem Revisited. In Lotte Jensen (ed.), The roots of nationalism. National identity formation in Early Modern Europe, 1600-1815, 67-83. Amsterdam: Amsterdam University Press.

Belle, Jan van. 1748. Korte wegwyzer, ter spel-spraak- en dichtkunden. Haarlem: Izaak van der Vinne.

Belle, Jan van. 1755. Korte schets der Nederduitse spraakkonst. Haarlem: Bohn.

Bendix, Regina. 1997. In search of authenticity. The formation of folklore studies. Madison: The University of Wisconsin Press. 
Beredeneerd plan tot het vervaerdigen van een algemeen, omschryvend woordenboek der Nederlandsche tale. 1773. Leiden.

Berg, Willem van den. 1999. De Tweede Klasse: een afdeling met een problematische missie (1806-1816). In Willem van den Berg, Een bedachtzame beeldenstorm. Beschouwingen over de letterkunde van de achttiende en negentiende eeuw, 137-165. Amsterdam: Amsterdam University Press.

Bergs, Alexander. 2005. Social Networks and Historical Sociolinguistics: Studies in morphosyntactic variation in the Paston letters (1421-1503). Berlin: De Gruyter.

https://doi.org/10.1515/9783110923223

Bergman, J. T. 1851-1852. Verslag van het bij de Maatschappij der Nederlandsche Letterkunde, te Leiden, weleer verrigte, ter vervaardiging van een algemeen omschrijvend woordenboek der Nederlandsche taal, gedurende de jaren 1770-1796. Archief voor Nederlandsche Taalkunde 3. 213-250.

Berlin, Isaiah. 1976. Herder and the Enlightenment. In Isaiah Berlin, Vico and Herder. Two studides in the history of ideas, 145-216. London: Hogarth Press.

Bezoen, H. L. 1952. Het Dumbar-handschrift. Idioticon van het Overijsels in het einde der achttiende eeuw. Deventer: N.V. Uitg.-Mij Æ.E. Kluwer.

Biber, Douglas \& Susan Conrad. 2009. Register, genre, and style. Cambridge: Cambridge University Press. https://doi.org/10.1017/CBO9780511814358

Bilt, Igor van de. 2003. 'Een dialectbriefje uit de 18de eeuw'. Het WNT en de Walcherse woorden van Adriaan Kluit. Trefwoord, http://www.inl.nl/images/stories/onderzoek_en_onderwijs/ publicaties/trefwoord/vandebilt.pdf

Bilt, Igor van de. 2009. Landkaartschrijvers en landverdelers. Adriaen Verwer (ca. 1655-1717), Adriaan Kluit (1735-1807) en de Nederlandse taalkunde van de achttiende eeuw. Amsterdam: Stichting Neerlandistiek VU \& Münster: Nodus Publikationen.

Blommaert, Jan \& Jef Verschueren. 1998. Debating diversity. Analysing the discourse of tolerance. London: Routledge.

Boekholt, P. Th. F. M. 1978. Het lager onderwijs in Gelderland 1795-1858. Zutphen: Walburg Pers.

Boekholt, P. Th. F. M. \& E. P. de Booy. 1987. Geschiedenis van de school in Nederland vanaf de middeleeuwen tot aan de huidige tijd. Assen \& Maastricht: Van Gorcum.

Bolhuis, Lambertus van. 1793 [21799]. Beknopte Nederduitsche spraakkunst. Leiden: D. du Mortier en zoon \& Deventer: J. H. de Lange \& Groningen: J. Oomkens en zoon.

Bonth, R. J. G. de. 1998. 'De Aristarch van 't Y'. De 'grammatica' uit Balthazar Huydecopers Proeve van Taal- en Dichtkunde (1730). Maastricht: Shaker.

Bonth Roland de, Jan Noordegraaf \& Gijsbert Rutten (eds.). 2016. Nicolaas Hinlópen, Eerste trekken eener Nederduitsche spraekkonste. Uitgegeven en ingeleid. Amsterdam: Stichting Neerlandistiek VU \& Münster: Nodus Publikationen.

Booy, E. P. de. 1977. De weldaet der scholen. Het plattelandsonderwijs in de provincie Utrecht van 1580 tot het begin der 19de eeuw. S.l.: Stichtse Historische Reeks.

Braekman, W. L. 1978. Twee nieuwe traktaten uit de vroege zestiende eeuw over de Nederlandse spelling. Verslagen en Mededelingen van de Koninklijke Academie voor Nederlandse Taal-en Letterkunde 2. 294-387.

Bredero, G. A. 1618. Spaanschen Brabander. Ed. by C. F. P. Stutterheim. Culemborg, 1974: Tjeenk Willink-Noorduijn.

Bree, Cor van \& Arjen P. Versloot. 2008. Oorsprongen van het Stadsfries. Ljouwert: Afûk. 
Brunner, Otto, Werner Conze \& Reinhart Koselleck (eds.). 1972-1997. Geschichtliche Grundbegriffe: Historisches Lexikon zur politisch-sozialen Sprache in Deutschland. 8 vols. Stuttgart: Klett-Cotta.

Burke, Peter. 1992. We, the people: Popular culture and popular identity in Modern Europe. In Scott Lash \& Jonathan Friedman (eds.), Modernity and identity. Oxford \& Cambridge, MA: Blackwell, 293-308.

Burke, Peter. 2004. Languages and communities in Early Modern Europe. Cambridge: Cambridge University Press. https://doi.org/10.1017/CBO9780511617362

Burke, Peter. 2009. Popular culture in Early Modern Europe. 3rd ed. [1st ed. 1978]. Farnham: Ashgate.

Byvoegsels en aenmerkingen op het beredeneerd plan tot het vervaerdigen van een algemeen, omschryvend woordenboek der Nederlandsche tale. 1774. Leiden.

Cameron, Deborah. 2012. The commodification of language: English as a global commodity. In Terttu Nevalainen \& Elizabeth Closs Traugott (eds.), The Oxford handbook of the history of English, 352-361. Oxford: Oxford University Press.

Capelle, Johannes Pieter van. 1816. Redevoering over de verdiensten der Amsterdammers, ten aanzien van den opbouw en de volmaking der Nederduitsche taal- en letterkunde. Amsterdam: Stads-drukkerij.

Carey, Daniel \& Lynn Festa (eds.). 2013. The postcolonial Enlightenment: Eighteenth-century colonialism and postcolonial theory. Oxford: Oxford University Press. https://doi.org/10.1093/acprof:osobl/9780199677597.001.0001

Certeau, Michel de, Dominique Julia \& Jacques Revel. 1975. Une politique de la langue: la Révolution française et les patois, l'enquête Grégoire. Paris: Gallimard.

Châtelain, H. A. 1766. Antwoord op de vraag [...]: hoe moet men het verstand, en het hart van een kind bestieren, om het, ten eenigen tyde, een nuttig en gelukkig mensch te doen worden? Verhandelingen uitgegeeven door de Hollandsche Maatschappye der Weetenschappen IX-II. 1-304.

Christmann, Hans Helmut. 1966. Beiträge zur Geschichte der These vom Weltbild der Sprache. Mainz: Akademie der Wissenschaften und der Literatur \& Wiesbaden: Franz Steiner Verlag. Cooper, R. L. 1989. Language planning and social change. New York: Cambridge University Press. Coupland, Nikolas. 2003. Sociolinguistic authenticities. Journal of Sociolinguistics 7. 417-431. https://doi.org/10.1111/1467-9481.00233

Coupland, Nikolas. 2014. Language, society and authenticity: Themes and perspectives. In Véronique Lacoste, Jakob Leimgruber \& Thiemo Breyer (eds.), Indexing authenticity. Sociolinguistic perspectives, 14-39. Berlin: De Gruyter.

Crowley, Tony. 1996. Language in history. Theory and texts. London \& New York: Routledge. https://doi.org/10.4324/9780203416440

C.V.E. 1775. Onderzoek, waarom de dieren niet spreeken, en hoe de menschen hebben begonnen te spreeken. Rhapsodist IV. 181-230.

Daan, Jo. 1958. Boeren-Haarlems op de keper beschouwd. Taal \& Tongval 10. 54-62.

Daan, Jo. 1989. Als niet komt tot iet... Nederlands van hoog tot laag. Verslagen en mededelingen van de Koninklijke Vlaamse Academie voor Nederlandse Taal-en Letterkunde, 168-245.

Daan, Jo. 1992. Wat is een dialect. De betekenisnuances van dit woord in Nederland, bij Lambert ten Kate en in latere eeuwen. Taal \& Tongval 44. 156-187.

Davies, P. 2005. Writing slates and schooling. Australiasian Historical Archeology 23. 63-69.

Dekker, Jeroen J. H. 2006. Het verlangen naar opvoeden. Over de groei van de pedagogische ruimte in Nederland sinds de Gouden Eeuw tot omstreeks 1900. Amsterdam: Bert Bakker. 
Dekker, Ton. 2002. De Nederlandse volkskunde. De verwetenschappelijking van een emotionele belangstelling. Amsterdam: Aksant.

De Smedt, Marcel. 1979. Uit de voorgeschiedenis van het WNT. Handelingen Koninklijke Zuidnederlandse Maatschappij voor Taal- en Letterkunde en Geschiedenis 33. 109-130.

Deumert, Ana \& Wim Vandenbussche. 2003. Research directions in the study of language standardization. In Ana Deumert \& Wim Vandenbussche (eds.), Germanic standardizations. Past to present, 461-476. Amsterdam \& Philadelphia: Benjamins.

https://doi.org/10.1075/impact.18.18deu

Deumert, Ana \& Wim Vandenbussche (eds.). 2003. Germanic Standardizations. Past to Present. Amsterdam \& Philadelphia: Benjamins. https://doi.org/10.1075/impact.18

De Wulf, C., J. Goossens \& J. Taeldeman. 2005. Fonologische atlas van de Nederlandse dialecten. Deel IV. De consonanten. Ghent: Koninklijke Academie van Nederlandse Taal- en Letterkunde.

Dibbets, G. R. W. 1968. Nederduitse orthographie van Pontus de Heuiter (1581). Een inleiding. Assen: Van Gorcum \& Comp. N.V.

Dibbets, G. R. W. 1977. Grammaticale geschriften uit de zestiende eeuw. In D. M. Bakker \& G. R. W. Dibbets (eds.), Geschiedenis van de Nederlandse taalkunde, 23-37. Den Bosch: Malmberg.

Dibbets, G. R. W. 1985. See Twe-spraack 1584.

Dibbets, G. R. W. 1992. Moonens 'Nederduitsche Spraekkunst' (1706) in brieven aan Vollenhove. Tijdschrift voor Nederlandse taal- en letterkunde 108. 256-275.

Dibbets, G. R. W. 1995. Petrus Francius Voorrede (1996): een pleidooi voor kerkelijke welsprekendheid. Voortgang. Jaarboek voor de neerlandistiek 15. 149-187.

Dibbets, G. R. W. 1996. De strijd om het genus in de achttiende-eeuwse grammatica van het Nederlands. In R. de Bonth \& J. Noordegraaf (eds.), Linguistics in the Low Countries. The eighteenth century, 57-90. Amsterdam: Stichting Neerlandistiek VU \& Münster: Nodus Publikationen.

Dibbets, G. R. W. 2003a [ $\left.{ }^{1} 1991\right]$. Vondels zoon en Vondels taal. Joannes Vollenhove en het Nederlands. 2nd revised edition. Published online: http://www.dbnl.org/tekst/dibb001vond01_01/ index.php

Dibbets, G. R. W. 2003b. Taal kundig geregeld. Een verzameling artikelen over Nederlandse grammatica's en grammatici uit de zestiende, de zeventiende en de achttiende eeuw. Amsterdam: Stichting Neerlandistiek VU \& Münster: Nodus Publikationen.

Dibbets, G. R. W. 2003c. Christiaen van Heule: 'ijsbreker, langs een allermoeijelijkst vaarwater'?. Nijmegen: Katholieke Universiteit Nijmegen.

Dibbets, G. R. W. 2007. Joannes Vollenhove (1631-1708). Dominee-dichter. Een biografie. Hilversum: Verloren.

Dodde, N. L. 1971. Een onderwijsrapport. Een historisch-pedagogisch onderzoek naar de invloed van een onderwijsrapport over onderwijsverbetering en -vernieuwing op de onderwijswetgeving na 1801. 's-Hertogenbosch: Malmberg.

Doja, Albert. 1998. Évolution et folklorisation des traditions culturelles. East European Quarterly 33. $95-126$.

Donaldson, Bruce. 1983. Dutch. A linguistic history of Holland and Belgium. Leiden: Martinus Nijhoff.

Dossena, Marina. 2012. The study of correspondence: Theoretical and methodological issues. In Marina Dossena \& Gabriella Del Lungo Camiciotti (eds.), Letter writing in Late Modern Europe, 13-30. Amsterdam \& Philadelphia: Benjamins.

https://doi.org/10.1075/pbns.218.02dos 
Driel, Lo van. 1992. 19th-century linguistics: The Dutch development and the German theme. In Jan Noordegraaf, Kees Versteegh \& Konrad Koerner (eds.), The history of linguistics in the Low Countries, 221-254. Amsterdam \& Philadelphia: Benjamins. https://doi.org/10.1075/sihols.64.10dri

Driel, Lo van \& Jan Noordegraaf. 1998. De Vries en Te Winkel. Een duografie. The Hague: Sdu \& Antwerp: Standaard.

Driel, Lo van \& Nicoline van der Sijs. 2018. Adriaan Kluit: Back to the sources! In Rick Honings, Gijsbert Rutten \& Ton van Kalmthout (eds.), Language, literature and the construction of a national identity (1780-1830), 205-226. Amsterdam: Amsterdam University Press.

Dykstra, Anne. 1999. De leksikografy fan it Nijfrysk. In Anne Dykstra \& Rolf H. Bremmer, Jr. (eds.), In skiednis fan 'e Fryske taalkunde, 191-212. Ljouwert: Fryske Akademy.

Edwards, John. 2009. Language and identity. An introduction. Cambridge: Cambridge University Press. https://doi.org/10.1017/CBO9780511809842

Eekma, Petrus. 1819. Handleiding tot de Nederduitsche taalkennis. Leeuwarden: Wed. C. L. van Altena.

Effen, Justus van. 1984 [1731-1735]. De Hollandsche spectator. Ed. by P. J. Buijnsters. Deventer: Sub Rosa.

Elspaß, Stephan. 2005. Sprachgeschichte von Unten. Untersuchungen zum Geschriebenen Alltagsdeutsch im 19. Jahrhundert. Tübingen: Niemeyer.

https://doi.org/10.1515/9783110910568

Elspaß, Stephan. 2007. 'Everyday language' in emigrant letters and its implications for language historiography: The German case. Multilingua 26. 151-165.

https://doi.org/10.1515/MULTI.2007.008

Elspaß, Stephan. 2014. Prescriptive norms and norms of usage in nineteenth-century German. In Gijsbert Rutten, Rik Vosters \& Wim Vandenbussche (eds.), Norms and usage in language history, 1600-1900. A sociolinguistic and comparative perspective, 303-320. Amsterdam \& Philadelphia: Benjamins.

Elspaß, Stephan \& Nils Langer. 2012. Jespersen's cycle and the history of German negation: Challenges from a sociolinguistic perspective. Neuphilologische Mitteilungen 113. 275-292.

Elzevier, Kornelis. 1761. Drie Dichtproeven [...] Benevens een proef van een nieuwe Nederduitsche spraekkonst. Haarlem: J. Bosch.

Endepols, H. J. E. 1955. Woordenboek of diksjenaer van 't Mestreechs. Maastricht: Boosten \& Stols.

Engelen, C. van. 1779. Antwoord op de vraag, van de Maatschappy der Nederlandsche Letterkunde. Welke zijn de algemeene oogmerken, die een dichter moet bedoelen? Welke zijn derhalven de eigenaartige onderwerpen voor de dichtkonst? En welke zijn derzelver algemeene regelen? Werken van de Maetschappy der Nederlandsche Letterkunde 4. 63-224.

Esling, John H. 1999. Everyone has an accent except me. In Laurie Bauer \& Peter Trudgill (eds.), Language myths, 169-175. London etc: Penguin.

Et en Fret. Het oudste stuk in Stads-Grunnegers. 1957 [1793]. Ed. K. ter Laan. Wildervank: N. V.

De Noord-Ooster.

Fairman, Tony. 2007a. Writing and 'the Standard': England, 1795-1834. Multilingua 26. 167-201.

Fairman, Tony. 2007b. 'Lower-order' letters, schooling and the English language, 1795 to 1834. In Stephan Elspaß, Nils Langer, Joachim Scharloth \& Wim Vandenbussche (eds.) Germanic language histories 'from below' (1700-2000), 31-43. Berlin: De Gruyter.

https://doi.org/10.1515/9783110925463.31 
Fairman, Tony. 2015. Language in print and handwriting. In A. Auer, D. Schreier \& R. Watts (eds.), Letter writing and language change, 53-73. Cambridge: Cambridge University Press. https://doi.org/10.1017/CBO9781139088275.005

van der Feest Viðarsson, Heimir. 2017. The syntax of others: 'Un-Icelandic' verb placement in 19th- and early 20th-century Icelandic. In Ingrid Tieken-Boon van Ostade \& Carol Percy (eds.), Prescription and tradition in language: Establishing standards across time and space, 152-167. Bristol: Multilingual Matters.

Feitsma, Anthonia. 2012. Tussen Hemsterhuis en Grimm. Joast Hiddes Halbertsma als taalkundige. Ljouwert: Afûk.

Fens-de Zeeuw, Lyda. 2011. Lindley Murray (1745-1826), quaker and grammarian. Utrecht: LOT. Fitzmaurice, Susan. 2010. Changes in the meanings of politeness in eighteenth-century England: discourse analysis and historical evidence. In Jonathan Culpeper \& Dániel Kádár (eds.), Historical (im)politeness, 87-115. Bern: Peter Lang.

Frijhoff, Willem. 1983. Van onderwijs naar opvoedend onderwijs. Ontwikkelingslijnen van opvoeding en onderwijs in Noord-Nederland in de achttiende eeuw. Documentatieblad Werkgroep Achttiende Eeuw, 3-39.

Frijhoff, Willem. 1989. Verfransing? Franse taal en Nederlandse cultuur tot in de revolutietijd. Bijdragen en mededelingen betreffende de geschiedenis der Nederlanden 104. 592-609.

Frijhoff, Willem \& Marijke Spies. 1999. 1650. Bevochten eendracht. The Hague: Sdu.

Francius, Petrus. 1699. Gregorius Nazianzenus van de mededeelzaamheidt. Amsterdam: Wetsteen. $\mathrm{GA}=$ Groninger Archieven, Groningen .

Gal, Susan. 2016. Sociolinguistic differentiation. In Nikolas Coupland (ed.), Sociolinguistics. Theoretical debates, 113-135. Cambridge: Cambridge University Press.

https://doi.org/10.1017/CBO9781107449787.006

Gal, Susan \& Kathryn Woolard. 2001. Constructing languages and publics. Authority and representation. In Susan Gal \& Kathryn Woolard (eds.), Language and publics. The making of authority, 1-12. Manchester: St Jerome.

Gedenkschriften der Maatschappij tot Nut van 't Algemeen voor de eerste vijfentwintig jaren van haar bestaan. 1809. Amsterdam: Cornelis de Vries, Hendrik van Munster \& Johannes van der Hey.

Geeraerts, Dirk. 2003. Cultural models of linguistic standardization. In René Dirven, Roslyn Frank \& Martin Pütz (eds), Cognitive models in language and thought. Ideology, metaphors and meaning, 25-68. Berlin \& New York: De Gruyter. https://doi.org/10.1515/9783110892901.25

Geeraerts, Dirk \& Hans Van de Velde. 2013. Supra-regional characteristics of colloquial Dutch. In Frans Hinskens \& Johan Taeldeman (eds.), Language and space. An international handbook of linguistic variation. Volume 3: Dutch, 532-556. Berlin: De Gruyter.

Geerts, Guido. 1966. Genus en geslacht in de Gouden Eeuw. Brussels: Belgisch Interuniversitair Centrum voor Neerlandistiek.

Geesdalle, Jacques-François van. 1700. Le parallele de la grammaire des deux langues Francoise \& Flamende. Ghent: Maximilien Graet.

Gerritsen, Marinel. 2001. The dialectology of Dutch. In Sylvain Auroux, E. F. K. Koerner, Hans-Josef Niederehe \& Kees Versteegh (eds.), History of the language sciences, 1536-1553. Vol. 2. Berlin \& New York: De Gruyter.

Geschichtliche Grundbegriffe. Historisches Lexikon zur politisch-sozialen Sprache in Deutschland. 1992. Vol. 7. Ed. by Reinhart Koselleck. Stuttgart: Klett-Cotta.

Gestel, P. H. van \& G. C. F. van der Laan. 1915. Schrijven en schrijfonderwijs. Groningen: Wolters. 
Godreau, Isar. 2002. Changing space, making race: Distance, nostalgia and the folklorization of blackness in Puerto Rico. Identities 9. 281-304. https://doi.org/10.1080/10702890213969 Goossens, Jan. 2008. Dialectgeografische grondslagen van een Nederlandse taalgeschiedenis. Brussels: Koninklijke commissie voor toponymie en dialectologie.

Goossens, Jan \& Jacques van Keymeulen. 2006. Geschiedenis van de Nederlandse dialectstudie. Toponymie \& dialectologie 78. 73-97.

Grauwe, Luc De. 2002. Emerging mother-tongue awareness. The special case of Dutch and German in the Middle Ages and the Early Modern Period. In Andrew Linn \& Nicola McLelland (eds.), Standardization. Studies from the Germanic languages, 99-115. Amsterdam \& Philadelphia: Benjamins. https://doi.org/10.1075/cilt.235.o9deg

Grootaers, L. \& G. G. Kloeke. 1926. Handleiding bij het Noord- en Zuid-Nederlandsch dialectonderzoek. The Hague: Martinus Nijhoff. https://doi.org/10.1007/978-94-011-9148-7

Haagsch Nederduitsch woordenboekje. S.d. The Hague: Johannes Mensert.

Haan, Tj. W. R. de. 1958. Boeren-Haarlems uit 1732. Taal \& Tongval 10. 63-74.

Haas, Walter. 1994. Provinzialwörter. Deutsche Idiotismensammlungen des 18. Jahrhunderts. Berlin \& New York: De Gruyter. https://doi.org/10.1515/9783110898194

Haeringen, C. B. van. 1924. Eenheid en nuance in beschaafd-Nederlandse uitspraak. De Nieuwe Taalgids 18. 65-86.

Haes, Frans de. 1764. De nagelaten gedichten, en Nederduitsche spraekkunst. Amsterdam: Pieter Meijer.

Hagen, Anton M. 1988. Dutch dialectology: the national and the international perspective. Historiographia linguistica 15. 263-287. https://doi.org/10.1075/hl.15.1-2.13hag

Haitsma Mulier, E. O. G. 1996. De Bataafse mythe opnieuw bekeken. Bijdragen en mededelingen betreffende de geschiedenis der Nederlanden 111.344-367.

Halbertsma, J. H. 1836. Woordenboekje van het Overijselsch. Proeve. Overijsselsche almanak voor oudheid en letteren. 184ff [unnumbered pages].

Handelingen der jaarlijksche vergadering van de Maatschappij der Nederlandsche Letterkunde te Leyden. 1770, 1773, 1774, 1775, 1777, 1778, 1781, 1785, 1786, 1787, 1788, 1790. S.1., s.d.

Handelingen $1850 \mathrm{a}=$ Handelingen der jaarlijksche algemeene vergadering der Maatschappij van Nederlandsche Letterkunde te Leiden, gehouden den 21 Junij 1850 in het Locaal De Vink bij Leiden. Leiden s.d.: J. G. la Lau.

Handelingen $1850 \mathrm{~b}=$ Handelingen van het Nederlandsch congres, gehouden te Gent den 26, 27, 28 en 29 augustus 1849. Ghent, 1850: L. Hebbelynck.

Handelingen $1851=$ Handelingen van het tweede Nederlandsch letterkundig kongres, gehouden den $16 n, 17 n$, en $18 n$ september, 1850. Amsterdam, 1851: J. F. Schleijer.

Handelingen 1852 = Handelingen van het derde Nederlandsch letterkundig kongres, gehouden te Brussel, den 30 en 31 augustus 1851 en 1 september 1851. Brussels, 1852: J.-H. Dehou.

Handelingen 1855 = Handelingen van het vierde Nederlandsch taal- en letterkundig congres, gehouden te Utrecht op 20, 21 en 22 september 1854. Utrecht, 1855: J. G. Broese.

Hardie, Kim. 1996. Lowland Scots: Issues in nationalism and identity. In Charlotte Hoffmann (ed.), Language, culture and communication in contemporary Europe, 61-74. Cleveland, Philadelphia \& Adelaide: Multilingual Matters.

Haugen, Einar. 1966. Dialect, language, nation. American Anthropologist 68. 922-935. https://doi.org/10.1525/aa.1966.68.4.02aooo40

Haugen, Einar. 1972. Language planning, theory and practice. In Einar Haugen, The ecology of language. Essays by Einar Haugen, 287-295. Stanford: Stanford Unversity Press. 
Haugen, Einar. 1987. Blessings of Babel. Bilingualism and language planning. Problems and pleasures. Berlin, New York \& Amsterdam: Mouton de Gruyter.

https://doi.org/10.1515/9783110862966

Havinga, Anna. 2015. Germanising Austria: The invisibilisation of East Upper German in eighteenth- and nineteenth-century Austria. In Anna Havinga \& Nils Langer (eds.), Invisible languages in the nineteenth century, 257-279. Oxford: Peter Lang.

https://doi.org/10.3726/978-3-0353-0760-3/18

Havinga, Anna \& Nils Langer (eds.). 2015. Invisible languages in the nineteenth century. Oxford: Peter Lang. https://doi.org/10.3726/978-3-0353-0760-3

Hawkey, James \& Nils Langer. 2016. Language policy in the long nineteenth century: Catalonia and Schleswig. In Cinzia Russi (ed.), Current trends in historical sociolinguistics, 81-107. Berlin: De Gruyter Open, https://www.degruyter.com/downloadpdf/books/ 9783110488401/9783110488401-008/9783110488401-008.xml https://doi.org/10.1515/9783110488401-008

Heeroma, K. 1960. Veluws en Drents uit de 18de eeuw. Driemaandelijkse bladen 12. 65-83, 97-116.

Heeroma, K. 1967. Lambertus van Bolhuis als 18de-eeuws Groninger dialectoloog. Driemaandelijkse bladen 19. 98-130.

Heeroma, K. 1968a. Brabants uit de 18de eeuw. De Meierijse woordenlijsten van J. L. Verster. Amsterdam: N.V. Noord-Hollandsche Uitgevers Maatschappij.

Heeroma, K. 1968b. Nog meer 18de-eeuwse Groningana. Driemaandelijkse bladen 20. 164-175.

Helten, W. L. van. 1881. Vondel's taal. Een proeve van onderzoek naar de grammatica van het Nederlandsch der zeventiende eeuw. 2 vols. Rotterdam: Otto Petri.

Hemsterhuis, Tiberius. 2017. Lectio publica de originibus linguae Graecae (ca 1750). With a translation and a commentary by Bouke Slofstra. 2nd ed. Amsterdam: Stichting Neerlandistiek VU \& Münster: Nodus Publikationen.

Henstra, Froukje. 2014. Horace Walpole and his correspondents. Social network analysis in a historical context. Utrecht: LOT.

Herder, Johann Gottfried. 1772. Abhandlung über den Ursprung der Sprache. Ed. by Hans Dietrich Irmscher. 2001. Stuttgart: Reclam.

Herrgen, Joachim. 2001. Die Dialektologie des Deutschen. In Sylvain Auroux, E. F. K. Koerner, Hans-Josef Niederehe \& Kees Versteegh (eds.), History of the language sciences, 1513-1535. Vol. 2. Berlin \& New York: De Gruyter.

Heuiter, Pontus de. 1581. Nederduitse orthographie. Ed. by G. R. W. Dibbets. Groningen, 1972: Wolters-Noordhoff.

Heule, Christiaen van. 1625. De Nederduytsche grammatica ofte spraec-konst. Ed. by W. J. H. Caron. Groningen \& Jakarta, 1953: J. B. Wolters.

Heule, Christiaen van. 1633. De Nederduytsche spraec-konst ofte tael-beschrijvinge. Leiden: Roels. Hickey, Raymond (ed.). 2010. Eighteenth-century English: Ideology and change. Cambridge: Cambridge University Press. https://doi.org/10.1017/CBO9780511781643

Hickey, Raymond. 2012. Supraregionalisation. In Laurel Brinton \& Alexander Bergs (eds.), Historical linguistics of English, 2060-2075. Berlin: De Gruyter.

Hobsbawm, Eric J. 1990. Nations and nationalism since 1780. Programme, myth, reality. Cambridge: Cambridge University Press.

Hoeufft, J. H. 1836. Proeve van Bredaasch taal-eigen. Breda: F. P. Sterk.

Honings, Rick. 2011. Geleerdheids zetel, Hollands roem! Het literaire leven in Leiden 1760-1860. Leiden: Primavera Pers. 
Honings, Rick. 2018. Poet and professor: Adam Simons. In Rick Honings, Gijsbert Rutten \& Ton van Kalmthout (eds.), Language, literature and the construction of a Dutch national identity (1780-1830), 73-96. Amsterdam: Amsterdam University Press.

https://doi.org/10.5117/9789089648273

Honings, Rick, Gijsbert Rutten \& Ton van Kalmthout (eds). 2018. Language, literature and the construction of a Dutch national identity (1780-1830). Amsterdam: Amsterdam University Press. https://doi.org/10.5117/9789089648273

Hooft, P. C. 1617. Warenar. In W. Hellinga \& P. Tuyman (eds.), Alle de gedrukte werken $1611-$ 1738, 225-267. Amsterdam, 1972: Amsterdam University Press.

Hoogstraten, David van. $1700\left[{ }^{2} 1710,{ }^{3} 1723\right]$. Aenmerkingen over de geslachten der zelfstandige naemwoorden. Amsterdam: Halma.

Hoorn, I. van. 1907. De Nederlandse schoolwetgeving voor het lager onderwijs, 1796-1907. Groningen: Noordhoff.

Hornberger, Nancy H. 2006. Frameworks and models in language policy and planning. In Thomas Ricento (ed.), An introduction to language policy. Theory and method, 24-41. Malden, Oxford \& Victoria: Blackwell.

Horner, Kristine \& Joanne Kremer. 2016. Shifting ideologies of linguistic authority: Language, nation and citizenship in Luxembourg. In Gijsbert Rutten \& Kristine Horner (eds), Metalinguistic perspectives on Germanic languages: European case studies from past to present, 239-260. Oxford: Peter Lang.

Horst, Joop van der. 2008. Geschiedenis van de Nederlandse syntaxis. 2 vols. Louvain: Universitaire Pers Leuven.

Houtam, H. 1775. Onderzoek over de benaamingen der Nederduitsche naamvallen. Tael- en dichtlievende oefeningen van het genootschap ter spreuke voerende: Kunst wordt door arbeid verkreegen, 145-186. Vol. 1. Leiden: C. van Hoogeveen.

Hulshof, Hans, Erik Kwakernaak \& Frans Wilhelm. 2015. Geschiedenis van het talenonderwijs in Nederland. Onderwijs in de moderne talen van 1500 tot heden. Groningen: Uitgeverij Passage.

Hundt, Markus. 2000. 'Spracharbeit' im 17. Jahrhundert. Studien zu Georg Philipp Harsdörffer, Justus Georg Schottelius und Christian Gueintz. Berlin \& New York: De Gruyter.

Huydecoper, Balthazar. 1730. Proeve van taal- en dichtkunde. Amsterdam: E. Visscher \& J. Tirion. Huygens, Constantijn. 1653. Trijntje Cornelis. Ed. by H. M. Hermkens. Utrecht, 1987: HES.

Instructie voor den Agent der Nationale Opvoeding. 1799. The Hague: S.n.

Ichijo, Atsuko. 2004. Scottish nationalism and the idea of Europe: Concepts of Europe and the nation. London \& New York: Routledge. https://doi.org/10.4324/9780203337806

Iperen, Josua van. 1762a. Uitnoodiginge der liefhebbers en kenners van onze moedertale, tot het helpen toestellen van een oordeelkundig Nederduitsch woordenboek. Maendelijksche by-dragen ten opbouw van Neer-land's tael-en dicht-kunde XLVII. 509-514.

Iperen, Josua van. 1762b. Schetze van woorden-scharinge en zin-bepalinge, die men hoopt te volgen, in het toestellen van een oordeelkundig Nederduitsch woordenboek. Maendelijksche by-dragen ten opbouw van Neer-land's tael-en dicht-kunde XLVIII. 541-551.

Irvine, Judith T. \& Susan Gal. 2000. Language ideology and linguistic differentiation. In Paul V. Kroskrity (ed.), Regimes of language. Ideologies, polities, and identities, 35-83. Santa Fe: School of American Research Press.

Israel, Jonathan. 1996. De Republiek, 1477-1806. Franeker: Van Wijnen.

Israel, Jonathan. 2001. Radical Enlightenment. Philosophy and the making of modernity, 1650-1750. Oxford: Oxford University Press. https://doi.org/10.1093/acprof:0so/9780198206088.001.0001 
J. A. 1842. Groningsch taaleigen. Taalkundig Magazijn 4. 655-690.

Janssens, Guy \& Ann Marynissen. 2008. Het Nederlands vroeger en nu. 3rd ed. Louvain \& Voorburg: Acco.

Janssens, Guy \& Kris Steyaert. 2008. Het onderwijs van het Nederlands in de Waalse provincies en Luxemburg onder koning Willem I (1814-1830). Brussels: VUB Press.

Jensen, Lotte. 2012. De Gouden Eeuw als ijkpunt van de nationale identiteit. Het beeld van de Gouden Eeuw in verzetsliteratuur tussen 1806 en 1813. De Zeventiende Eeuw 28. 161-175.

Jensen, Lotte. 2016. The roots of nationalism. Introduction. In Lotte Jensen (ed.), The roots of nationalism. National identity formation in Early Modern Europe, 1600-1815, 9-27. Amsterdam: Amsterdam University Press.

Jensen, Lotte. 2018. The founding father of Dutch literary history: Jeronimo de Vries. In Rick Honings, Gijsbert Rutten \& Ton van Kalmthout (eds.), Language, literature and the construction of a Dutch national identity (1780-1830), 277-296. Amsterdam: Amsterdam University Press.

Jespersen, Otto. 1925. Mankind, nation and individual from a linguistic point of view. Oslo: $\mathrm{H}$. Aschehoug \& Co.

Jeune, J. C. W. Le. 1835. Bouwstoffen voor de Nederlandsche letterkunde en hare geschiedenis. Vol. 3. The Hague: G. Vervloet.

Johannes, Gert-Jan. 2002. Zoo is overdrijving de ziekte van elke eeuw. Het beeld van de 17de eeuw in 19de-eeuwse literatuurgeschiedenissen voor schoolgebruik en zelfstudie. Nederlandse Letterkunde 7. 28-60.

Johannes, Gert-Jan. 2011. 'Nationale filologieën' en het historisch onderzoek naar disciplinevorming in de geesteswetenschappen. Een verkenning. Studium 4. 31-46. https://doi.org/10.18352/studium.1531

Johannes, Gert-Jan. 2015. 'Dutch Language and Literature' (and other 'national philologies') as an example of discipline formation in the humanities. In Ton van Kalmthout \& Huib Zuidervaart (eds.), The practice of philology in the nineteenth-century Netherlands, 37-52. Amsterdam: Amsterdam University Press.

Johnstone, Barbara. 2009. Pittsburghese shirts: Commodification and the enregisterment of an urban dialect. American Speech 84. 157-175. https://doi.org/10.1215/00031283-2009-013

Jong, Alpita de. 2009. Knooppunt Halbertsma. Joast Hiddes Halbertsma (1789-1869) en andere Europese geleerden over het Fries en andere talen, over wetenschap en over de samenleving. Hilversum: Verloren.

Joseph, John E. 1987. Eloquence and power. The rise of language standards and standard languages. New York: Blackwell.

Joseph, John E. 2004. Language and identity. National, ethnic, religious. Houndmills etc: Palgrave Macmillan.

Karstens, Bart. 2012. Bopp the builder. Discipline formation as hybridization: the case of comparative linguistics. In Rens Bod, Jaap Maat \& Thijs Weststeijn (eds.), The making of the humanities. Volume II. From Early Modern to Modern disciplines, 103-127. Amsterdam: Amsterdam University Press.

Kate, Lambert ten. 1723. Aenleiding tot de kennisse van het verhevene deel der Nederduitsche sprake. 2 vols. Ed. by J. Noordegraaf \& M. van der Wal. Alphen aan den Rijn, 2001: Canaletto.

Kedourie, Elie. 1993. Nationalism. 4th ed. Oxford: Blackwell.

Kerswill, Paul. 2002. Koineization and accommodation. In J. K. Chambers, Peter Trudgill \& Natalie Schilling-Estes (eds.), The handbook of language variation and change, 669-702. Oxford: Blackwell. 
Kessels-van der Heijde, M. C. A. 2015. The use of languages in Maastricht in the nineteenth century: the press and family archives. In Catharina Peersman, Gijsbert Rutten \& Rik Vosters (eds.), Past, present and future of a language border. Germanic-Romance encounters in the Low Countries, 171-204. Berlin \& New York: De Gruyter.

https://doi.org/10.1515/9781614514152-010

Kinker, Johannes. 1810. Proeve eener Hollandsche prosodia. Werken der Hollandsche maatschappij van fraaije kunsten en wetenschappen. Vol. 1. 1-328.

Kinker, Johannes. 1829. Beoordeeling van M. W. Bilderdijks Nederlandsche spraakleer. Amsterdam: Johannes van der Hey en zoon.

Kirchdorffer, J. S. 1825. Nederduitsche spraakkunst, ten dienste der scholen. 2nd ed. Amsterdam: Schalekamp, Van de Grampel \& Hanssen.

Kirkness, Alan. 1980. Geschichte des Deutschen Wörterbuchs. 1838-1863. Dokumente zu den lexikographen Grimm. Stuttgart: S. Hirzel Verlag.

Klippi, Carita. 2013. Letters from Gaston B. A prisoner's voice during the Great War. In Marijke van der Wal \& Gijsbert Rutten (eds.). Touching the past. Studies in the historical sociolinguistics of ego-documents, 107-128. Amsterdam \& Philadelphia: Benjamins. https://doi.org/10.1075/ahs.1.06kli

Kloek, Joost \& Wijnand Mijnhardt. 2001. 1800: Blauwdrukken voor een samenleving. The Hague: Sdu.

Kloeke, G. G. 1926. Geschiedenis van het Noord-Nederlandsch dialectonderzoek. In L. Grootaers \& G. G. Kloeke, Handleiding bij het Noord- en Zuid-Nederlandsch dialectonderzoek, 1-26. The Hague: Martinus Nijhoff. https://doi.org/10.1007/978-94-011-9148-7_1

Kloeke, G. G. 1938. Haagse volkstaal uit de achttiende eeuw. Tijdschrift voor Nederlandse Taal- en Letterkunde 57. 15-56.

Kloss, Heinz. 1952. Die Entwicklung neuer germanischer Kultursprachen von 1800 bis 1950. München: Pohl.

Kluit, Adriaan. 1763. Eerste vertoog over de tegenwoordige spelling der Nederduitsche taal. Nieuwe Bydragen tot de opbouw der vaderlandsche letterkunde I. 281-352.

Kluit, Adriaan. 1777. Vertoog over de tegenwoordige spelling der Nederduitsche taal. Werken van de Maetschappy der Nederlandsche letterkunde te Leyden III. 1-42.

Knippenberg, H. 1986. Deelname aan het lager onderwijs in Nederland gedurende de negentiende eeuw. Amsterdam: Koninklijk Nederlands Aardrijkskundig Genootschap.

Knippenberg, H. 1992. De Religieuze Kaart van Nederland. Assen: Koninklijke Van Gorcum

Koch, Peter \& Wulf Oesterreicher. 1985. Sprache der Nähe - Sprache der Distanz: Mündlichkeit und Schriftlichkeit im Spannungsfeld von Sprachtheorie und Sprachgebrauch. Romanistisches Jahrbuch 36. 15-43.

Komen, J. A. M. 1994. Over de ontwikkeling van absolute constructies. Amsterdam: Buijten en Schipperheijn B.V.

Kooi, J. van der. 1983. Dialect als wapen. Eind-achttiende eeuwse voorbeelden uit De Onverwachte Courier. Driemaandelijkse bladen 35. 125-132.

Koolhaas-Grosfeld, Eveline. 2010. De ontdekking van de Nederlander in boeken en prenten rond 1800. Zutphen: Walburg Pers.

Kossmann, F. K. H. 1966. Opkomst en voortgang van de Maatschappij der Nederlandse Letterkunde te Leiden. Leiden: E. J. Brill.

Krogull, Andreas. 2018. Policy versus practice. Language variation and change in eighteenthand nineteenth-century Dutch. PhD dissertation Leiden University. 
Krogull, Andreas, Gijsbert Rutten \& Marijke van der Wal. 2017. Relativisation in Dutch diaries, private letters and newspapers (1770-1840): A genre-specific national language? In Tanja Säily, Arja Nurmi, Minna Palander-Collin \& Anita Auer (eds.), Exploring future paths for historical sociolinguistics, 157-186. Amsterdam \& Philadelphia: Benjamins.

https://doi.org/10.1075/ahs.7.07kro

Krom, H. J. 1782. Antwoord op de vraage: welke verbeteringe hebben de gemeene of openbaare, vooral de Nederduitsche Schoolen, ter meerdere beschavinge onzer Natie, nog wel nodig? Hoe zou die op de voordeeligste wyze kunnen ingevoerd, en, op een bestendigen voet, onderhouden worden? Verhandelingen uitgegeven door het Zeeuwsch genootschap der wetenschappen te Vlissingen 8. 1-228.

Kunst wordt door Arbeid Verkreegen. 1770. Nederduitsche spraekkunst, ten gebruike van het genootschap. Leiden: s.n.

Lambin, Jan-Jacques. 1837. Straettael van Ypre. Belgisch Museum 1. 396-407.

Lambrecht, Joas. 1550. Néderlandsche spellijnghe. Ghent: Joas Lambrecht.

Langer, Nils. 2011. Historical sociolinguistics in nineteenth-century Schleswig-Holstein. German Life and Letters 64. 169-178. https://doi.org/10.1111/j.1468-0483.2010.01528.x

Langer, Nils. 2014. Standard German in the eighteenth century. Norms and use. In Gijsbert Rutten, Rik Vosters \& Wim Vandenbussche (eds.), Norms and usage in language history, 1600-1900. A sociolinguistic and comparative perspective, 277-302. Amsterdam \& Philadelphia: Benjamins.

Laurman, M. T. 1822. Proeve van kleine taalkundige bijdragen tot beter kennis van den tongval in de provincie Groningen. Groningen: W. van Boekeren.

Leemans, Inger \& Gert-Jan Johannes. 2013. Worm en donder. Geschiedenis van de Nederlandse literatuur 1700-1800: de Republiek. Amsterdam: Bert Bakker.

Leerssen, Joep. 2006. Nationalism and the cultivation of culture. Nations and Nationalism 12. 559-578. https://doi.org/10.1111/j.1469-8129.2006.00253.x

Leerssen, Joep. 2007. Exoticism. In Manfred Beller \& Joep Leerssen (eds.), Imagology. The cultural construction and literary representation of national characters, 325-326. Amsterdam \& New York: Rodopi.

Leerssen, Joep. 2010. National thought in Europe. A cultural history. Amsterdam: Amsterdam University Press.

Leerssen, Joep. 2012. The rise of philology. The comparative method, the historicist turn and the surreptitious influence of Giambattista Vico. In Rens Bod, Jaap Maat \& Thijs Weststeijn (eds.), The making of the humanities. Volume II. From Early Modern to Modern disciplines, 23-35. Amsterdam: Amsterdam University Press.

Leerssen, Joep (ed.). 2018. Encyclopedia of Romantic Nationalism in Europe. 2 vols. Amsterdam: Amsterdam University Press. See also ernie.uva.nl https://doi.org/10.5117/9789462981188

Lenders, Jan. 1988. De burger en de volksschool. Culturele en mentale achtergronden van een onderwijshervorming. Nijmegen: SUN.

Le Page, R. B. \& A. Tabouret-Keller. 1985. Acts of identity. Creole-based approaches to language and ethnicity. Cambridge: Cambridge University Press.

Leupenius, Petrus. 1653. Aanmerkingen op de Neederduitsche taale. Amsterdam: Hendryk Donker.

Leuvensteijn, Arjan van. 2008. Lambert ten Kates opbouwmissie: de Gemééne-lands-spraake. In Lo van Driel \& Theo Janssen (eds.), Ontheven aan de tijd. Linguïstisch-historische studies voor Jan Noordegraaf, 85-94. Amsterdam: Stichting Neerlandistiek VU \& Münster: Nodus Publikationen. 
Lijst, van Groningsche woorden. 1837. Taalkundig Magazijn 2. 329-344.

Linn, Andrew R. \& Nicola McLelland (eds.). 2002. Standardization. Studies from the Germanic languages. Amsterdam \& Philadelphia: Benjamins. https://doi.org/10.1075/cilt.235

Lippi-Green, Rosina. 1997 [22012]. English with an accent. Language, ideology, and discrimination in the United States. London \& New York: Routledge.

Lodge, R. Anthony. 1993. French: From dialect to standard. London: Routledge. https://doi.org/10.4324/9780203319994

Lodge, R. Anthony. 2004. A sociolinguistic history of Parisian French. Cambridge: Cambridge University Press. https://doi.org/10.1017/CBO9780511486685

Lodge, Anthony. 2013. Codification and reallocation in seventeenth-century Paris. Taal \& Tongval 65. 57-72. https://doi.org/10.5117/TET2013.1.LODG

Lodge, Anthony. 2014. Jacques-Louis Ménétra and his experience of the langue d'oc. In Gijsbert Rutten, Rik Vosters \& Wim Vandenbussche (eds.), Norms and usage in language history, 1600-1900. A sociolinguistic and comparative perspective, 201-221. Amsterdam \& Philadelphia: Benjamins.

Los, Willeke. 2005. Opvoeding tot mens en burger. Pedagogiek als cultuurkritiek in Nederland in de 18 e eeuw. Hilversum: Verloren.

Lulofs, Barthold Henrik. 1815. Inwijdingsredevoering over de noodzakelijkheid van de beoefening der eigene taal en letterkunde voor de zelfstandigheid en den roem van eene natie. Groningen: Oomkens.

Lulofs, Barthold Henrik. 1819. Schets van een overzigt der Duitsche taal, of der Germaansche taaltakken. Groningen: Oomkens.

MAND II = Morfologische atlas van de Nederlande dialecten. Deel II. By Ton Goeman, Marc van Oostendorp, Pieter van Reenen, Oele Koornwinder, Boudewijn van den Berg \& Anke van Reenen. Amsterdam, 2008: Amsterdam University Press.

Martinet, Johannes Florentius. 1769. II. antwoord op de vraage voorgesteld door de Hollandsche Maatschappye der weetenschappen: wat is 'er tot nu toe over de natuurlijke historie van ons vaderland geschreeven? Verhandelingen uitgegeeven door de Hollandsche Maatschappye der weetenschappen te Haarlem XI-2. 63-326.

Martineau, France. 2007. Variation in Canadian French usage from the 18th to the 19th century. Multilingua 26. 203-227. https://doi.org/10.1515/MULTI.2007.010

Marynissen, Ann. 1998. Van -(t)ke naar - $(t) j e$. De oorsprong en verspreiding van het Nederlandse diminutiefsuffix -(t)je. Tijdschrift voor Nederlandse Taal- en Letterkunde 114. 252-269.

Marynissen, Ann. 2004. Limburgers worden Nederlanders? Over de vernederlandsing van het zuidoosten van Nederlands Limburg. Taal \& Tongval. Themanummer 17. 64-85.

Mattheier, Klaus J. 2003. German. In Ana Deumert \& Wim Vandenbussche (eds.), Germanic standardizations. Past to present, 211-244. Amsterdam \& Philadelphia: Benjamins. https://doi.org/10.1075/impact.18.ogmat

Mauricius, Joan Jacob. 1765. Onledige ouderdom [...] eerste deel, behelzende taallievende en historische uitspanningen. Amsterdam: G. de Groot \& Zn., \& Petrus Schouten.

McCafferty, Kevin \& Carolina P. Amador Moreno. 2012. 'I will be expecting a letter from you before this reaches you'. A corpus-based study of shall/will variation in Irish English correspondence. In Marina Dossena \& Gabriella Del Lungo Camiciotti (eds.), Letter writing in Late Modern Europe, 179-204. Amsterdam \& Philadelphia: Benjamins. https://doi.org/10.1075/pbns.218.11mcc 
McColl Millar, Robert. 2012. The problem of reading dialect in semiliterate letters. The correspondence of the Holden Family, 1812-16 and of Richard Taylor, 1840-51. In Marina Dossena \& Gabriella Del Lungo Camiciotti (eds.), Letter writing in Late Modern Europe, 163-177. Amsterdam \& Philadelphia: Benjamins. https://doi.org/10.1075/pbns.218.10mil

McLelland, Nicola. 2014. Language description, prescription and usage in seventeenth-century German. In Gijsbert Rutten, Rik Vosters \& Wim Vandenbussche (eds.), Norms and usage in language history, 1600-1900. A sociolinguistic and comparative perspective, 251-275. Amsterdam \& Philadelphia: Benjamins.

Meertens, P. J. 1960. Een Middelburgse dialectbrief uit 1795. Taal \& Tongval 12. 88-93.

Meiden, Willem van der. 2009. 'Zoo heerlijk eenvoudig'. Geschiedenis van de kinderbijbel in Nederland. Hilversum: Verloren.

Meijer, Gerrit Joan. 1822. Redevoering over de beoefening der Nederlandsche taal, het beste middel ter bevordering van ware vaderlandsliefde. Louvain: C. J. de Mat.

Mertens, Jozef. 2010. Onder invloed van Jan Frans Willems en Pieter Ecrevisse: 19de-eeuwse mythevorming rond taal, herkomst, handel en wandel van de Kempense teuten. Verslagen \& Mededelingen van de Koninklijke Academie voor Nederlandse Taal- en Letterkunde 120. 37-92.

Mestingh, Derk. 1771. Verhandeling over den oorsprong en de natuur der taalen in het gemeen beschouwd. Groningen: Hajo Spandaw.

Meurman-Solin, Anneli. 2000. Change from above or from below? Mapping the loci of linguistic change in this history of Scottish English. In Laura Wright (ed.), The development of Standard English 1300-1800, 155-170. Cambridge: Cambridge University Press.

https://doi.org/10.1017/CBO9780511551758.010

Meves, Uwe (ed.). 2011. Deutsche Philologie an den preußischen Universitäten im 19. Jahrhundert.

Dokumente zum Institutionalisierungsprozess. Vol. 1. Berlin: De Gruyter.

https://doi.org/10.1515/9783110235630

Meyerhoff, Miriam. 2011. Introducing sociolinguistics. 2nd edn. London \& New York: Routledge.

Michaelis, Johann David. 1771. Prysverhandeling over den wederkeerigen invloed van de aangenoomen begrippen onder een volk op de nationaale taal, en van de taal op de nationaale wyze van denken. Transl. by Cornelis van Engelen. Harlingen: Volkert van der Plaats Junior.

Mihm, Arend. 1998. Arbeitersprache und gesprochene Sprache im 19. Jahrhundert. In Dieter Cherubim, Klaus J. Mattheier \& Siegfried Grosse (eds.), Sprache und bürgerliche Nation, 282-316. Berlin: De Gruyter. https://doi.org/10.1515/9783110807035.282

Mijnhardt, Wijnand. 1987. Tot heil van 't menschdom. Culturele genootschappen in Nederland, 1750-1815. Amsterdam: Rodopi.

Milroy, James. 1992. Social network and prestige arguments in sociolinguistics. In K. Bolton \& H. Kwok (eds.), Sociolinguistics today. International perspectives, 146-162. London: Routledge.

Milroy, James. 2000. Historical description and the ideology of the standard language. In Laura Wright (ed.), The Development of Standard English, 1300-1800. Theories, Descriptions, Conflicts, 11-28. Cambridge: Cambridge University Press.

https://doi.org/10.1017/CBO9780511551758.002

Milroy, James. 2001. Language ideologies and the consequences of standardization. Journal of Sociolinguistics 5. 530-555. https://doi.org/10.1111/1467-9481.00163

Milroy, James \& Lesley Milroy. 2012 [11985]. Authority in language. Investigating Standard English. 4th Ed. London and New York: Routledge. 
Milroy, James, Lesley Milroy \& Sue Hartley. 1994. Local and supra-local change in British English: The case of glottalisation. English World-Wide 15. 1-32. https://doi.org/10.1075/eww.15.1.02mil

Moerdijk, A. 1994. Enige algemene informatie over het WNT, http://www.inl.nl/images/stories/ onderzoek_en_onderwijs/lexicologie_en_lexicografie/wnt_enige_algemene_informatie_ moerdijk.pdf

Molhuysen, P. C. 1924. Bronnen tot de geschiedenis der Leidsche universiteit. Volume 7. The Hague: Martinus Nijhoff.

Momma, Haruko. 2013. From philology to English studies. Language and culture in the nineteenth century. Cambridge: Cambridge University Press.

Mone, F. J. 1836. Bemerkung über die Volkssprache in Brabant. Anzeiger für die Kunde der deutschen Vorzeit 5. 215-220.

Moonen, Arnold. 1706. Nederduitsche spraekkunst. Amsterdam: Halma.

Mugglestone, Lynda. 2003 [ $\left.{ }^{1} 1995\right]$. Talking proper. The rise of accent as social symbol. Oxford: Oxford University Press.

Negele, Michaela. 2012. Varianten der Pronominaladverbien im Neuhochdeutschen. Grammatische und soziolinguistische Untersuchungen. Berlin: De Gruyter.

https://doi.org/10.1515/9783110273281

Neis, Cordula. 2003. Anthropologie im Sprachdenken des 18. Jahrhunderts. Die Berliner Preisfrage nach dem Ursprung der Sprache (1771). Berlin \& New York: De Gruyter.

https://doi.org/10.1515/9783110896381

Nevala, Minna. 2004. Address in early English correspondence. Its forms and socio-pragmatic functions. Helsinki: Socíeté Néophilologique.

Nevalainen, Terttu. 2012. Variable focusing in English spelling between 1400 and 1600. In Susan Baddeley \& Anja Voeste (eds.), Orthographies in Early Modern Europe, 127-165. Berlin: De Gruyter. https://doi.org/10.1515/9783110288179.127

Nevalainen, Terttu. 2014. Norms and usage in seventeenth-century English. In Gijsbert Rutten, Rik Vosters \& Wim Vandenbussche (eds.), Norms and usage in language history, 16001900. A sociolinguistic and comparative perspective, 103-128. Amsterdam \& Philadelphia: Benjamins.

Nevalainen, Terttu \& Helena Raumolin-Brunberg. 2003. Historical sociolinguistics. Language change in Tudor and Stuart England. London etc: Longman.

Nevalainen, Terttu \& Gijsbert Rutten. 2012. Introduction: Comparative historical sociolinguistics and the history of negation. Neuphilologische Mitteilungen CXIII. 261-273.

Nevalainen, Terttu \& Ingrid Tieken-Boon van Ostade. 2006. Standardisation. In Richard Hogg \& David Denison (eds.), A history of the English language, 271-311. Cambridge: Cambridge University Press. https://doi.org/10.1017/CBO9780511791154.006

NHA $=$ Noord-Hollands Archief, Haarlem .

Niebaum, Hermann W. H. 2009. Stad-Gronings uit 1793. De taal van de humoristische toneelschets Et en Fret. Groningen: Rijksuniversiteit Groningen.

Nieuwe bydragen tot opbouw der vaderlandsche letterkunde. 1763/1766. 2 vols. Leiden: Pieter vander Eyk.

Nobels, Judith. 2013. (Extra) Ordinary letters. A view from below on seventeenth-century Dutch. Utrecht: LOT.

Nobels, Judith \& Gijsbert Rutten. 2014. Language norms and language use in seventeenth-century Dutch: Negation and the genitive. In Gijsbert Rutten, Rik Vosters \& Wim Vandenbussche (eds.), Norms and usage in language history, 1600-1900. A sociolinguistic and comparative perspective, 21-48. Amsterdam \& Philadelphia: Benjamins. 
Noordegraaf, Jan. 1975. De 'Maatschappij' en haar grammatici. De Nieuwe Taalgids 68. 121-124. Noordegraaf, Jan. 1985. Norm, geest en geschiedenis. Nederlandse taalkunde in de negentiende eeuw. Dordrecht \& Cinnaminson: Foris.

Noordegraaf, Jan. 1996. The 'Schola Hemsterhusiana' revisited. In Jan Noordegraaf, The Dutch pendulum. Linguistics in the Netherlands 1740-1900, 23-55. Münster: Nodus Publikationen. Noordegraaf, Jan. 1997. Het begin van de universitaire neerlandistiek: Franeker 1790? In Jan Noordegraaf, Voorlopig verleden. Taalkundige plaatsbepalingen, 1797-1960, 14-27. Münster: Nodus Publikationen.

Noordegraaf, Jan. 1999. Vaderland en moedertaal. Een constante in het taalkundig denken. In N. C. F. van Sas (ed.), Vaderland. Een geschiedenis vanaf de vijftiende eeuw tot 1940, 343363. Amsterdam: Amsterdam University Press.

Noordegraaf, Jan. 2004a. A matter of time: Dutch philosophy of language in the eighteenth century. In Thomas F. Shannon \& Johan P. Snapper (eds.), Janus at the millennium. Perspectives on time in the culture of the Netherlands, 211-225. Dallas etc: University Press of America.

Noordegraaf, Jan. 2004b. L. van Bolhuis. In Karina van Dalen-Oskam, Ingrid Biesheuvel, Wim van Anrooij \& Jan Noordegraaf (eds.), Bio- en bibliografisch lexicon van de neerlandistiek, http://www.dbnl.org/tekst/anro001bioe01_01/bolh003.php

Noordegraaf, Jan. 2012. Over taal en maatschappij in de achttiende eeuw. Het werk van Meinard Tydeman (1741-1825). Neerlandica Wratislaviensia 21. 87-100.

Noordegraaf, Jan. 2015. Linguistics as a profession. Diverging opinions in the nineteenth century. In Ton van Kalmthout \& Huib Zuidervaart (eds.), The practice of philology in the nineteenth-century Netherlands, 115-145. Amsterdam: Amsterdam University Press.

Noordegraaf, Jan. 2018. Pieter Weiland and his Nederduitsche Spraakkunst. In Rick Honings, Gijsbert Rutten \& Ton van Kalmthout (eds.), Language, literature and the construction of a Ducth national identity (1780-1830), 145-165. Amsterdam: Amsterdam University Press.

Nordlund, Taru. 2007. Double diglossia - lower class writing in 19th-century Finland. Multilingua 26. 229-246. https://doi.org/10.1515/MULTI.2007.011

Nordlund, Taru \& Ritva Pallaskallio. 2017. Competing norms and standards. Methodological triangulation in the study of language planning in nineteenth-century Finland. In Tanja Säily, Arja Nurmi, Minna Palander-Collin \& Anita Auer (eds.), Exploring future paths for historical sociolinguistics, 131-156. Amsterdam \& Philadelphia: Benjamins.

https://doi.org/10.1075/ahs.7.06nor

Nylöe, Jacobus. 1703. Aanleiding tot de nederduitsche taal. Amsterdam: Borstius.

Ontwerp van de Maatschappy der Nederlandsche Letterkunde te Leyden, tot het vervaerdigen van een algemeen, omschryvend woordenboek der Nederlandse tale. 1774. Leiden.

Ontwerp tot het opstellen en bewerken van een Nederduitsch omschryvend woordenboek. 1791. Leiden.

Onverwachte courier. 1796. Groningen etc: Leonard Bolt etc.

Opmerkingen omtrent den Gelderschen tongval. 1837. Taalkundig Magazijn 2. 395-426.

Osselton, N. E. 1984. Spelling systems in Early Modern English: 1500-1800. In N. F. Blake \& Charles Jones (eds), English historical linguistics. Studies in development, 123-137. Sheffield: Centre for English Cultural Tradition and Language.

Palm, Kornelis van der. 1766. Verhandeling over de vraeg: hoe moet men het verstandt, en het hart van een kindt bestieren, om het, te eeniger tydt, een gelukkig en nuttig mensch te doen worden. Verhandelingen uitgegeeven door de Hollandsche Maatschappye der Weetenschappen IX-II. 1-194.

Palm, Kornelis van der. 1769. Nederduitsche spraekkunst, voor de jeugdt. Rotterdam: Reinier Arrenberg. 
Palm, Kornelis van der. 1782. Antwoord op dezelfde vraage: Over de verbetering der schoolen. Verhandelingen uitgegeven door het Zeeuwsch Genootschap der Wetenschappen te Vlissingen 8. 229-316.

Palmer, D. J. 1965. The rise of English studies. An account of the study of English language and literature from its origins to the making of the Oxford English school. London, New York \& Toronto: Oxford University Press.

Petiet, Francien. 2011. 'Een voldingend bewijs van ware vaderlandsliefde'. De creatie van literair erfgoed in Nederland, 1797-1845. Unpublished PhD dissertation, University of Amsterdam.

Petiet, Francien. 2018. Barthold Hendrik Lulofs: A 'Learned Dilettante'. In Rick Honings, Gijsbert Rutten \& Ton van Kalmthout (eds.), Language, literature and the construction of a Ducth national identity (1780-1830), 49-71. Amsterdam: Amsterdam University Press.

Ploeg, H. W. van der. 1800. Het belang der waare volksverlichting. Amsterdam: Wed. Harm. Keijzer, Corns. de Vries and Hendrik van Munster.

Poplack, Shana, Lidia-Gabriela Jarmasz, Nathalie Dion \& Nicole Rosen. 2015. Searching for Standard French: The construction and mining of the Recueil historique des grammaires $d u$ français. Journal of Historical Sociolinguistics 1. 13-55. https://doi.org/10.1515/jhsl-2015-0002 Porter, Roy \& Mikuláš Teich (eds.). 1981. The Enlightenment in national context. Cambridge etc: Cambridge University Press. https://doi.org/10.1017/CBO9780511561283

Preston, Dennis. 2002. Language with an attitude. In J. K. Chambers, Peter Trudgill \& Natalie Schilling-Estes (eds.), The handbook of language variation and change, 40-66. Oxford: Blackwell.

Priestly, Tom. 2001. Dialectology in the Slavic countries: An overview from its beginnings to the early twentieth century. In Sylvain Auroux, E. F. K. Koerner, Hans-Josef Niederehe \& Kees Versteegh (eds.), History of the language sciences, 1563-1572. Vol. 2. Berlin \& New York: De Gruyter.

Proeve van oudheid-, taal- en dichtkunde. 1775/1780. 2 vols. Utrecht: A. van Paddenburg \& J. van Schoonhoven \& Comp.

Pudor, Christian. 1672. Der Teutschen Sprache Grundrichtigkeit, und Zierlichkeit. Cölln an der Spree: S.n.

Puikers, J. 1824. Eerste onderwijs in de gronden der Nederduitsche taal, ten dienste der scholen. 5th ed. Rotterdam: J. Hendriksen.

Quak, A. \& J. M. van der Horst. 2002. Inleiding Oudnederlands. Louvain: Universitaire Pers Leuven.

Rogers, Mark. 1999. Spectacular bodies: Folklorization and the politics of identity in Ecuadorian beauty pageants. Journal of Latin American Anthropology 3. 54-85.

https://doi.org/10.1525/jlca.1998.3.2.54

Romaine, Suzanne. 2009 [1982]. Socio-historical linguistics: Its status and methodology. Cambridge: Cambridge University Press.

Rossem, Cefas van. 1994. Annaeus Ypeij and the Frisian language. In Ph.H. Breuker, H. D. Meijering \& J. Noordegraaf (eds.), Wat oars as mei in echte taal, 186-199. Ljouwert: Fryske Akademy.

Rudimenta, of gronden der Nederduitsche spraake. 1802. 2nd ed. Leiden: D. du Mortier en zoon \& Deventer: J. H. de Lange \& Utrecht: G. T. van Paddenburg en zoon. [See also van Varik 1799.]

Rudimenta, of gronden der Nederduitsche taal. 1805. Vol. I (morphology). Leiden: D. du Mortier en zoon \& Deventer: J. H. de Lange \& Groningen: J. Oomkens en zoon. [See also van Varik 1799.] 
Rutten, Gijsbert. 2003a. Vondels 'volkomen voorbeeldt'. Transmissie van Vondelianisme in de achttiende eeuw: een didactisch program. De Achttiende Eeuw 35. 135-152.

Rutten, Gijsbert. 2003b. Verwer, Van Hoogstraten en het verleden. De politieke betekenis van twee achttiende-eeuwse taalgeschiedenissen. In Els Ruijsendaal, Gijsbert Rutten \& Frank Vonk (eds.), Bon jour neef, ghoeden dagh cozyn! Opstellen voor Geert Dibbets, 189-201. Münster: Nodus Publikationen.

Rutten, Gijsbert. 2004. The nationalist turn. Dutch linguistics and German philosophy in the eighteenth and early nineteenth centuries. In Douglas A. Kibbee (ed.), History of linguistics 2005, 288-307. Amsterdam \& Philadelphia: Benjamins.

Rutten, Gijsbert. 2005. Reason and usage in Early Modern Dutch linguistics. Valuation, revaluation. Beiträge zur Geschichte der Sprachwissenschaft 15. 71-89.

Rutten, Gijsbert. 2006. De Archimedische punten van de taalbeschouwing. David van Hoogstraten (1658-1724) en de vroegmoderne taalcultuur. Amsterdam: Stichting Neerlandistiek VU \& Münster: Nodus Publikationen.

Rutten, Gijsbert. 2007. Remark and Remember. Cultivating Dutch in Early Modern Europe. Henry Sweet Society Bulletin 49. 39-52.

Rutten, Gijsbert. 2008a. Jan van Belle: didacticus, popularisator. In Th. Janssen \& L. van Driel (eds.), Ontheven aan de tijd. Lingü̈stisch-historische studies voor Jan Noordegraaf, 95-104. Amsterdam: Stichting Neerlandistiek VU \& Münster: Nodus Publikationen.

Rutten, Gijsbert. 2008b. Norms for style and grammar in eighteenth-century Dutch prose, and the effect of education and of writing experience. Historical Sociolinguistics and Sociohistorical Linguistics 8, http://www.hum2.leidenuniv.nl/hsl_shl/Rutten.htm

Rutten, Gijsbert. 2009. Grammar to the people. The Dutch language and the public sphere in the 18th Century. With special reference to Kornelis van der Palm. Beiträge zur Geschichte der Sprachwissenschaft 2009. 55-86.

Rutten, Gijsbert. 2011. In cooperation with Rik Vosters. Een nieuwe Nederduitse spraakkunst. Taalnormen en schrijfpraktijken in de Zuidelijke Nederlanden in de achttiende eeuw. Brussels: VUB-Press.

Rutten, Gijsbert. 2012. 'Lowthian' linguistics across the North Sea. Historiographia Linguistica 39. 43-59. https://doi.org/10.1075/hl.39.1.04rut

Rutten, Gijsbert. 2016a. Historicizing diaglossia. Journal of Sociolinguistics 20. 6-30. https://doi.org/10.1111/josl.12165

Rutten, Gijsbert. 2016b. Diaglossia, individual variation and the limits of standardization: Evidence from Dutch. In Cinzia Russi (ed), Current trends in historical sociolinguistics, 194-218. Berlin: De Gruyter Open, https://www.degruyter.com/view/product/475491?format=G\# https://doi.org/10.1515/9783110488401-012

Rutten, Gijsbert. 2016c. The 'Golden Age Myth': The construction of Dutch as a national language. In Gijsbert Rutten \& Kristine Horner (eds.), Metalinguistic perspectives on Germanic languages. European case studies from past to present, 13-34. Oxford: Peter Lang. https://doi.org/10.3726/b11384

Rutten, Gijsbert. 2016d. Teaching the genitive. Variation of genitival constructions in Dutch 'national' grammar (1800-1830). Beiträge zur Geschichte der Sprachwissenschaft 26. 123-138.

Rutten, Gijsbert. 2016e. Standardization and the Myth of Neutrality in language history. International Journal of the Sociology of Language 24. 25-57.

Rutten, Gijsbert. 2018. Matthijs Siegenbeek in defense of Dutch. In Rick Honings, Gijsbert Rutten \& Ton van Kalmthout (eds.), Language, literature and the construction of a national identity (1780-1830), 25-47. Amsterdam: Amsterdam University Press. 
Rutten, Gijsbert, Andreas Krogull \& Bob Schoemaker. Accepted for publication in Language Policy. Implementation and acceptance of national language policy. The case of Dutch (1750-1850).

Rutten, Gijsbert, Rik Vosters \& Wim Vandenbussche (eds.). 2014. Norms and usage in language history, 1600-1900. A sociolinguistic and comparative perspective. Amsterdam \& Philadelphia: Benjamins.

Rutten, Gijsbert, Rik Vosters \& Marijke van der Wal. 2015. Frenchification in discourse and practice: Loan morphology in Dutch private letters of the eighteenth and nineteenth centuries. In C. Peersman, G. Rutten \& R. Vosters (eds.), Past, present and future of a language border: Germanic-Romance encounters in the Low Countries, 143-169. Berlin \& New York: De Gruyter. https://doi.org/10.1515/9781614514152-009

Rutten, Gijsbert \& Marijke van der Wal. 2011. Local dialects, supralocal writing systems. The degree of orality of Dutch private letters from the seventeenth century. Written language \& literacy 14. 251-274. https://doi.org/10.1075/wll.14.2.04rut

Rutten, Gijsbert \& Marijke van der Wal. 2013. Change, contact and conventions in the history of Dutch. Taal \& Tongval 65. 97-123. https://doi.org/10.5117/TET2013.1.RUTT

Rutten, Gijsbert \& Marijke van der Wal. 2014. Letters as loot. A sociolinguistic approach to seventeenth- and eighteenth-century Dutch. Amsterdam \& Philadelphia: Benjamins.

Rutten, Gijsbert, Marijke van der Wal, Judith Nobels \& Tanja Simons. 2012. Negation in seventeenth- and eighteenth-century Dutch. A historical-sociolinguistic perspective. Neuphilologische Mitteilungen CXIII. 323-342.

Sairio, Anni. 2009. Language and letters of the Bluestocking network. Sociolinguistic issues in eighteenth-century epistolary English. Helsinki: Socíeté Néophilologique.

Salmons, Joseph. 2013. A history of German: What the past reveals about today's language. Oxford: Oxford University Press.

Sandersen, Vibeke. 2007. Writing ability and the written language of Danish private soldiers in the Three Years' War (1848-1850). Multilingua 26. 247-278. https://doi.org/10.1515/MULTI.2007.012

Sas, N. C. F. van. 2004. De metamorfose van Nederland. Van oude orde naar nieuwe moderniteit, 1750-1900. Amsterdam: Amsterdam University Press.

Schaars, F. A. M. 1988. De Nederduitsche spraekkunst (1706) van Arnold Moonen (1644-1711). Wijhe: Quarto.

Schaars, F. A. M. \& M. te Wilt. 1989. Jacobus Nylöe (1670-1714) en zijn Aanleiding tot de Nederduitsche taal. In G. R. W. Dibbets \& P. W. M. Wackers (eds.), Wat duikers vent is dit?, 267-294. Wije: Quarto.

Schama, Simon. 1970. Schools and politics in the Netherlands, 1796-1814. The Historical Journal 13. 589-610.

Schilperoort, T. Olivier. 1806. Proeve van nieuwere taalkunde, op de Nederduitsche spraakkunst toegepast. Groningen: J. Oomkens.

Schneider, Edgar W. 2013. Investigating historical variation and change in written documents. New perspectives. In J. K. Chambers \& Natalie Schilling (eds.), The handbook of language variation and change, 2nd ed., 57-81. Oxford: Blackwell.

https://doi.org/10.1002/9781118335598.ch3

Schoemaker, Bob. 2018. Gewijd der Jeugd, voor taal en deugd. Het onderwijs in de Nederlandse taal op de lagere school, 1750-1850. PhD dissertation Leiden University. 
Schoemaker, Bob \& Gijsbert Rutten. 2017. Standard language ideology and Dutch school inspection reports (1801-1854). Sociolinguistica 31. 101-116. https://doi.org/10.1515/soci-2017-0008

Schott, Robin May (ed.). 1997. Feminist interpretations of Immanual Kant. The Pennsylvania State University Press.

Schrant, Joannes Mathias. 1818. Redevoering over het beoefenenswaardige der Nederlandsche tale, zoo om haar zelve, als om hare voortbrengselen. Ghent: Houdin.

Serrure, Constant Philippe. 1841-1842. Over de inrigting en samenstelling van een algemeen Nederduitsch woordenboek. Proeve van een Leuvensch idiotikon. De Middelaer of Bydragen ter bevordering van tael, onderwys en geschiedenis 2. 277-299.

Séwel, Willem. 1708 [ $\left.{ }^{2} 1712\right]$. Nederduytsche spraakkonst. Amsterdam: Lansvelt.

Sexagius, Anthonius. 1576. De orthographia linguae belgicae. Louvain: Masius.

Siegenbeek, Matthijs. 1800. Twee redevoeringen. Leiden: L. Herdigh.

Siegenbeek, Matthijs. 1804a. Verhandeling over de Nederduitsche spelling. Amsterdam: Johannes Allart.

Siegenbeek, M. 1804b. Antwoord op de vraag, in hoe ver behoort de spelling der Nederduitsche taal geregeld te worden naar de welluidendheid en gemakkelijkheid der uitspraak? Werken der Bataafsche Maatschappij van Taal- en Dichtkunde 1. 1-108.

Siegenbeek, Matthijs. 1805. Kort begrip der verhandeling over de Nederduitsche spelling. Amsterdam: Johannes Allart.

Siegenbeek, Matthijs. 1807. Verhandeling over de dichterlijke verdiensten van Joost van den

Vondel. Werken der Bataafsche Maatschappij van Taal- en Dichtkunde 2. 35-108.

Siegenbeek, Matthijs. 1810a. Syntaxis, of woordvoeging der Nederduitsche taal. Leiden: D. du

Mortier en zoon \& Deventer: J. H. de Lange \& Groningen: J. Oomkens. [anonymously published]

Siegenbeek, Matthijs. 1810b. Antwoord op het voorstel der Bataafsche Maatschappij van Taal- en

Dichtkunde, vorderende een betoog van den rijkdom en de voortreffelijkheid der Neder-

duitsche taal, en eene opgave der middelen om de toenemende verbastering van dezelve tegen te gaan. Werken der Bataafsche Maatschappij van Taal-en Dichtkunde 5. 1-273.

Siegenbeek, Matthijs. 1814a. Grammatica of Nederduitsche spraakkunst. Leiden: D. du Mortier

en zoon \& Deventer: J. H. de Lange \& Groningen: J. Oomkens. [anonymously published]

Siegenbeek, Matthijs. 1814b. Over het verband tusschen de taal en het volkskarakter der

Nederlanderen. Museum, of verzameling van stukken ter bevordering van fraaije kunsten en wetenschappen 3. 89-125.

Siegenbeek, Matthijs. 1826. Beknopte geschiedenis der Nederlandsche letterkunde. Haarlem: Bohn. Siegenbeek, Matthijs. [1827]. [Short biography of Lambertus van Bolhuis]. Handelingen der jaarlijksche vergadering van de Maatschappij der Nederlandsche Letterkunde te Leiden ... 1827, 4-11. S.l., s.d.

Siegenbeek, Matthijs. 1836. Waarschuwing tegen eenige in zwang gebragte verbasteringen van de uitspraak onzer moedertaal. Nieuwe bijdragen ter bevordering van het onderwijs en de opvoeding, 42-53.

Siegenbeek, Matthijs. 1847. Lijst van woorden en uitdrukkingen met het Nederlandsch taaleigen strijdende. Leiden: S. en J. Luchtmans.

Siegenbeek, M., A. Simons \& J. P. van Capelle (eds). 1820. P. C. Hoofts Nederlandsche Historien. Amsterdam: Johannes van der Hey.

Sifflé, A. F. 1835. Over het Zeeuwsche taaleigen. Taalkundig magazijn 1. 169-174. 
Shorrocks, Graham. 2001. The dialectology of English in the British Isles. In Sylvain Auroux, E. F. K. Koerner, Hans-Josef Niederehe \& Kees Versteegh (eds.), History of the language sciences, 1553-1562. Vol. 2. Berlin \& New York: De Gruyter.

Sijs, Nicoline van der. 2004. Taal als mensenwerk. Het ontstaan van het ABN. The Hague: Sdu.

Simons, Tanja. 2013. Ongekend 18de-eeuws Nederlands. Taalvariatie in persoonlijke brieven. Utrecht: LOT.

Simons, Tanja \& Gijsbert Rutten. 2014. Language norms and language use in eighteenth-century Dutch. Final $n$ and the genitive. In Gijsbert Rutten, Rik Vosters \& Wim Vandenbussche (eds.), Norms and usage in language history, 1600-1900. A sociolinguistic and comparative perspective, 49-72. Amsterdam \& Philadelphia: Benjamins.

Singeling, Kees. 1996. Sociable men of letters. Literary sociability in the Netherlands in the second half of the eighteenth century. In K. Garber, H. Wismann \& W. Siebers (eds.), Europäische Sozietätsbewegung und demokratische Tradition, 881-894. Tübingen: Max Niemeyer. https://doi.org/10.1515/9783110963243.879

Sjoer, E. 1996. Lessen over welsprekendheid. Een typering van de retorica's van de eerste hoogleraren in de vaderlandse welsprekendheid in de Noordelijke Nederlanden (1797-1853). Amsterdam: IFOTT.

Smakman, Dick. 2012. The definition of the standard language: a survey in seven countries. International Journal of the Sociology of Language 218. 25-58.

Smith, Anthony D. 1986. The ethnic origins of nations. Oxford: Blackwell.

Sonius Swaagman, Jan. 2002. Commentatio over het Groninger dialect (1827). Ed. and translated by Siemon Reker, with the cooperation of J. de Wit. Groningen: Bureau Groninger Taal en Cultuur RUG.

SPIN = Study Platform on Interlocking Nationalisms, http://spinnet.humanities.uva.nl/

Spronck, Lou. 1962. De Maastrichtse dialektliteratuur voor 1840. In Miscellanea Trajectana. Bijdragen tot de geschiedenis van Maastricht, 435-495. Maastricht: Limburgs Geschied- en Oudheidkundig Genootschap.

Sterkenburg, P. G. J. van. 1992. Het Woordenboek der Nederlandsche Taal. Portret van een taalmonument. The Hague: Sdu.

Sterkenburg, P. G. J. van. 2011. Van woordenlijst tot woordenboek. Een geschiedenis van de woordenboeken van het Nederlands. Schiedam: Scriptum.

Stijl, Klaas. 1776 [21778]. Beknopte aanleiding tot de kennis der spelling, spraakdeelen, en zinteekenen van de Nederduitsche taal. Ed. by Lambertus van Bolhuis. Groningen: Jan Oomkens.

Sturkenboom, Dorothée. 1998. Spectators van hartstocht. Sekse en emotionele cultuur in de achttiende eeuw. Hilversum: Verloren.

Swaving, H. I. 1835. Opgave van eenige in Gelderland gebruikelijke woorden. Taalkundig magazijn 1. 305-330.

Swaving, H. I. 1837. Nalezing op mijne opgave van eenige in Gelderland gebruikelijke woorden. Taalkundig magazijn 2. 76-80.

Swiggers, Pierre. 1984. La Grammaire de Port-Royal et le 'parallélisme logico-grammatical'. Orbis. Bulletin international de documentation linguistique 23. 29-56.

Syrjänen, Kaj. 2012. Tracing the history of dialectological research in Finland. Les dossiers de HEL: la disciplinarisation des savoirs linguistiques. Histoire et epistémologie. Supplément électronique à la revue Histoire Epistémologie Langage. Vol. 5, <http://htl.linguist.univ-paris-diderot.fr/old/num5/num5>.

Taal- dicht- en letterkundig kabinet. 1781-1784. 6 vols. Amsterdam: C. Groenewoud.

Taal- dicht en letterkundig magazijn. 1785-1788. 3 vols. Amsterdam: C. Groenewoud. 
Taalkundige vragen voorgesteld aan de leden van de Maatschappy der Nederlandsche Letterkunde te Leyden. 1775. Leiden.

Tael- en dicht-kundige by-dragen. 1760/1762. Leiden: Johannes Le Mair.

Tamošiūnaitè, Aurelija. 2013. Ego-documents in Lithuanian. Orthographic identities at the turn of the twentieth century. In Marijke van der Wal \& Gijsbert Rutten (eds.), Touching the past. Studies in the historical sociolinguistics of ego-documents, 225-242. Amsterdam \& Philadelphia: Benjamins. https://doi.org/10.1075/ahs.1.12tam

Thobokholt, Bert. 1983. Het taal- en dichtlievend genootschap 'Kunst wordt door arbeid verkreegen' te Leiden, 1766-1800. Utrecht: Instituut De Vooys.

Tieken-Boon van Ostade, Ingrid. 2011. The bishop's Grammar. Robert Lowth and the rise of prescriptivism. Oxford: Oxford University Press.

Tieken-Boon van Ostade, Ingrid. 2014. Eighteenth-century English normative grammars and their readers. In Gijsbert Rutten, Rik Vosters \& Wim Vandenbussche (eds.), Norms and usage in language history, 1600-1900. A sociolinguistic and comparative perspective, 129-150. Amsterdam \& Philadelphia: Benjamins.

Tollenaere, F. de. 1977. De lexicografie in de negentiende en twintigste eeuw. In D. M. Bakker \& G. R. W. Dibbets (eds.), Geschiedenis van de Nederlandse taalkunde, 229-246. 's-Hertogenbosch: Malmberg.

Tollius, Herman. 1762. Reply to van Iperen 1762a, 1762b. Maendelijksche by-dragen ten opbouw van Neer-land's tael-en dicht-kunde XLIX. 583-590. [anonymously published]

Tollius, Herman. 2007. Proeve eener Aanleiding tot de Nederduitsche Letterkunst. Ed. Roland de Bonth. Amsterdam: Stichting Neerlandistiek VU \& Münster: Nodus Publikationen.

Toorn, M. C. van den, W. Pijnenburg, J. A. Leuvensteijn \& J. M. van der Horst (eds.). 1997. Geschiedenis van de Nederlandse taal. Amsterdam: Amsterdam University Press. https://doi.org/10.5117/9789053562345

Trudgill, Peter. 1972. Sex, covert prestige and linguistic change in the urban British English of Norwich. Language in Society 1. 179-195. https://doi.org/10.1017/So047404500000488

Twe-spraack vande Nederduitsche letterkunst. 1584. Ed. G. R. W. Dibbets. Assen \& Maastricht, 1985: Van Gorcum.

Tydeman, Meinard. 1775a. Betoog der nuttigheid en noodzakelijkheid van de beoffening onzer moedertaal. Proeve van oudheid-, taal- en dichtkunde, door het genootschap Dulces ante omnia musae 1. 1-14.

Tydeman, Meinard. 1775b. Vertoog over de dienstige middelen ter verbetering der Nederduitsche taal. Proeve van oudheid-, taal-en dichtkunde, door het genootschap Dulces ante omnia musae 1. 15-20.

Uitlegkundig woordenboek op de werken van Pieter Korneliszoon Hooft. 1825. Vol. I. Amsterdam: Pieper \& Ipenbuur.

Vaan, Michiel de. 2013. Hollands uit de achttiende eeuw: Het zogenaamde 'handschrift-Kool'. Een typescript door Klaas Heeroma (tussen 1968 en 1972). Tijdschrift voor Nederlandse Taal- en Letterkunde 129. 122-132. Electronic edition published online at http://www.tntl. nl/addenda/TNTL20132_Heeroma-2.pdf

Vaderlandsche letteroefeningen. 1761-1876. Amsterdam: Van der Kroe, Yntema et al.

Valle, José del (ed.). 2013. A political history of Spanish. The making of a language. Cambridge: Cambridge University Press. https://doi.org/10.1017/CBO9780511794339

Valle, José del \& Luis Gabriel-Stheeman. 2002. Nationalism, hispanismo, and monoglossic culture. In José del Valle \& Luis Gabriel-Stheeman (eds.), The battle over Spanish between 1800 and 2000, 1-13. London \& New York: Routledge. 
Vandenbussche, Wim. 2004. Triglossia and pragmatic variety choice in 19th century Flanders. A case study in historical sociolinguistics. Journal of Historical Pragmatics 5. 27-47. https://doi.org/10.1075/jhp.5.1.03van

Vandenbussche, Wim. 2007. Shared standardization factors in the history of sixteen Germanic languages. In Christian Fandrych \& Reinier Salverda (eds.), Standard, Variation und Sprachwandel in germanischen Sprachen, 25-36. Tübingen: Gunter Narr.

Varik, Gerrit van. 1799. Rudimenta, of gronden der Nederduitsche spraake. Leiden: D. du Mortier en zoon \& Deventer: J. H. de Lange \& Utrecht: G. T. van Paddenburg en zoon. [anonymously published]

Velde, Hans Van de, Mikhail Kissine, Evie Tops, Sander van der Harst \& Roeland van Hout. 2010. Will Dutch become Flemish? Autonomous developments in Belgian Dutch. Multilingua 29. 385-416. https://doi.org/10.1515/mult.2010.019

Verdam, J. 1890. Geschiedenis der Nederlandsche taal. Leeuwarden: Hugo Suringar.

Verhoeven, Th. H. T. 1994. Ter vorming van verstand en hart. Lager onderwijs in oostelijk NoordBrabant ca. 1770-1920. Hilversum: Verloren.

Verslag 1851-1852 [1809] = Verslag betrekkelijk de inrigting en vervaardiging van het algemeen Hollandsch woordenboek. Published in Archief voor Nederlandsche Taalkunde 3 (18511852). 321-342.

Verslag 1809 = Verslag van de Commissie der taalkundige werkzaamheden betrekkelijk der bastaardwoorden, uitgebragt in de vergadering der Tweede Klasse van het Koninklijk Instituut, op den 8sten van bloeimaand 1809. S.1.

Versteegh, Kees. 1986. Latinitas, Hellenismos, 'Arabiyya'. Historiographia Linguistica 13. 425-448. https://doi.org/10.1075/hl.13.2-3.16ver

Verwer, Adriaen. 1707. Linguae Belgicae idea grammatica, poetica, rhetorica. Amsterdam: Halma.

Verzameling van eenige aanmerkingen, uit de overige toegezonden antwoorden ontleend. 1782. Verhandelingen uitgegeven door het Zeeuwsch Genootschap der Wetenschappen te Vlissingen 8. 395-464.

Villa, Laura. 2015. Official orthographies, spelling debates and nation-building projects after the fall of the Spanish Empire. Written Language \& Literacy 18. 228-247. https://doi.org/10.1075/wll.18.2.03vil

Vis, George. 1992. Tussen Amsterdam en Brussel. J.-P. van Capelle en G.-J. Meijer: twee pioniers in de academische neerlandistiek. Verslagen en mededelingen van de Koninklijke Academie voor Nederlandse taal- en letterkunde, 79-98. Ghent: KANTL.

Vis, George. [s.d.]. Van Siegenbeek tot Lodewick. Verkenningen naar de geschiedenis van de studie der Nederlandse letterkunde, speciaal in het onderwijs. Alkmaar: Amsterdamse Historische Reeks.

Vogl, Ulrike. 2012. Multilingualism in a standard language culture. In M. Hüning, U. Vogl \& O. Moliner (eds.), Standard languages and multilingualism in European history, 1-42. Amsterdam \& Philadelphia: Benjamins. https://doi.org/10.1075/mdm.1.02vog

Vogl, Ulrike. 2015. Standard Language Ideology and the history of Romance-Germanic encounters. In C. Peersman, G. Rutten \& R. Vosters (eds.), Past, present and future of a language border: Germanic-Romance encounters in the Low Countries, 61-87. Berlin \& New York: De Gruyter. https://doi.org/10.1515/9781614514152-006

Voorst, D. C. van. 1782. Antwoord op de vraage: over de verbetering der schoolen. Verhandelingen uitgegeven door het Zeeuwsch Genootschap der Wetenschappen te Vlissingen 8. 317-394. 
Vooys, C. G. N. de. 1970 [1931]. Geschiedenis van de Nederlandse taal. Groningen: WoltersNoordhoff.

Vosters, Rik. 2013. Dutch, Flemish or Hollandic? Social and ideological aspects of linguistic convergence and divergence during the United Kingdom of the Netherlands (1815-1830). In E. Barát \& P. Studer (eds.), Ideological conceptualisations of language. Discourses of linguistic diversity, 35-54. Frankfurt: Peter Lang.

Vosters, Rik, Els Belsack, Jill Puttaert \& Wim Vandenbussche. 2014. Norms and usage in 19th-century Southern Dutch. In G. Rutten, R. Vosters \& W. Vandenbussche (eds.), Norms and usage in language history, 1600-1900. A historical-sociolinguistic and comparative perspective, 73-100. Amsterdam \& Philadelphia: Benjamins.

Vosters, Rik \& Gijsbert Rutten. 2013. Het Snoeijmes en de taalkunde in de Zuidelijke Nederlanden. In Snoeijmes der Vlaemsche Tale. Een anonieme tekst over taalkunde uit de achttiende eeuw, 1-33. Ed. by Rik Vosters \& Gijsbert Rutten. Ghent: Koninklijke Academie voor Nederlandse Taal- en Letterkunde.

Vosters, Rik \& Gijsbert Rutten. 2015. Three Southern shibboleths. Spelling features as conflicting identity markers in the Low Countries. Written Language \& Literacy 18. 260-274. https://doi.org/10.1075/wll.18.2.05vos

Vosters, Rik, Gijsbert Rutten \& Marijke van der Wal. 2010. Mythes op de pijnbank. Naar een herwaardering van de taalsituatie in de Nederlanden in de achttiende en negentiende eeuw. Verslagen en Mededelingen van de Koninklijke Academie voor Nederlandse Taal- en Letterkunde 120. 93-112.

Vosters, Rik, Gijsbert Rutten, Marijke van der Wal \& Wim Vandenbussche. 2012. Spelling and identity in the Southern Netherlands (1750-1830). In A. Jaffe, M. Sebba, J. Androutsopoulos \& S. Johnson (eds.), Orthography as social action. Scripts, spelling, identity and power, 135160. Berlin: De Gruyter. https://doi.org/10.1515/9781614511038.135

Vosters, Rik \& Wim Vandenbussche. 2012. Bipartite negation in 18th and early 19th century Southern Dutch. Sociolinguistic aspects of norms and variation. Neuphilologische Mitteilungen 2012. 343-364.

Vriend des Volks. 1796. Middelburg: Wed. W. en J. Abrahams.

Vries, Marleen de. 2001. Beschaven! Letterkundige genootschappen in Nederland, 1750-1800. Nijmegen: Vantilt.

Vries, M. de. 1882. Inleiding. In Woordenboek der Nederlandsche taal. Vol. I, pp. I-CXXVI. The Hague and Leiden etc.: M. Nijhoff and A. W. Sijthoff etc.

Wal, Marijke van der. 1990. Meer der geleerde weereld' hunne vernuftige gedachten als der jeugd' hunne lessen mede te deelen? Vragen over het gebruik van grammatika's. In J. den Besten (ed.), Vragende wijs. Vragen over tekst, taal en taalgeschiedenis, 223-230. Amsterdam \& Atlanta: Rodopi.

Wal, Marijke van der. 1994. Straattaal en slechte woorden: sociolinguïstische onderscheidingen in observaties en taalbeschouwing vóór 1800. In Ph. Breuker, H. D. Meijering \& J. Noordegraaf (eds.), 'Wat oars as mei in echte taal'. Fryske Stúdzjes, 54-61. Ljouwert: Fryske Akademy.

Wal, Marijke van der. 1995a. De moedertaal centraal. Standaardisatie-aspecten omstreeks 1650. The Hague: Sdu.

Wal, Marijke van der. 1995b. Logic, linguistics, and Simon Stevin in the context of the sixteenth and seventeenth centuries. In K. R. Jankowsky (ed.), History of linguistics 1993, 147-156. Amsterdam: Benjamins. 
Wal, Marijke van der. 1997. Grotius' taalbeschouwing in contemporaine context. Nederlandse Taalkunde 1. 14-34.

Wal, Marijke van der. 2002. Lambert ten Kate and eighteenth-century Dutch linguistics. Beiträge zur Geschichte der Sprachwissenschaft 12. 49-63.

Wal, Marijke van der. 2018. Johannes Kinker: A Kantian philosopher teaching Dutch language, literature, and eloquence. In Rick Honings, Gijsbert Rutten \& Ton van Kalmthout (eds.), Language, literature and the construction of a Dutch national identity (1780-1830), 97-117. Amsterdam: Amsterdam University Press.

Wal, Marijke van der \& Cor van Bree. 2008. Geschiedenis van het Nederlands. Utrecht: Spectrum. Wassenbergh, Everwinus. 1806. Taalkundige bijdragen tot den Frieschen tongval. Franeker: D. Romar.

Watts, Richard J. 1999. The ideology of dialect in Switzerland. In Jan Blommaert (ed.), Language ideological debates, 67-103. Berlin \& New York: De Gruyter.

https://doi.org/10.1515/9783110808049.67

Watts, Richard J. 2011. Language myths and the history of English. Oxford: Oxford University Press. https://doi.org/10.1093/acprof:0so/9780195327601.001.0001

Watts, Richard J. 2012. Language myths. In Juan Manuel Hernández-Campoy \& Juan Camilo Conde-Silvestre (eds), The Handbook of Historical Sociolinguistics, 585-606. Chichester: Blackwell. https://doi.org/10.1002/9781118257227.ch32

Watts, Richard J. \& Peter Trudgill (eds.). 2002. Alternative histories of English. London \& New York: Routledge. https://doi.org/10.4324/9780203468005

Weber, Jean-Jacques \& Kristine Horner. 2012. Introducing multilingualism. A social approach. London \& New York: Routledge.

Weijermars, Janneke. 2009. Neerlandistiek als bindmiddel van de natie: Hoogleraar Schrant in Gent, 1817-1830. De Negentiende Eeuw 33. 4-19.

Weijermars, Janneke. 2018. 'I am Revived as a Belgian': The Work of Jan Frans Willems. In Rick Honings, Gijsbert Rutten \& Ton van Kalmthout (eds.), Language, literature and the construction of a Dutch national identity (1780-1830), 187-203. Amsterdam: Amsterdam University Press.

Weijnen, A. A. 1966. Nederlandse dialectkunde. 2nd ed. Assen: Van Gorcum.

Weiland, Pieter. 1799. Nederduitsch taalkundig woordenboek. A. Vol. I. Amsterdam: Johannes Allart.

Weiland, Pieter. 1803. Nederduitsch taalkundig woordenboek. I-L. Amsterdam: Johannes Allart. Weiland, Pieter. 1805a. Nederduitsche spraakkunst. Amsterdam: Johannes Allart.

Weiland, Pieter. 1805b. Beginselen der Nederduitsche spraakkunst. Amsterdam: Johannes Allart. Weiland, Pieter. 1820. Nederduitsche spraakkunst ten dienste der scholen. Dordrecht: Blussé \& Van Braam.

Werken der Bataafsche Maatschappij van Taal- en Dichtkunde. 1804-1810. 5 vols. Amsterdam: Johannes Allart.

Werken van de Maetschappy der Nederlandsche Letterkunde te Leyden. 1772-1788. 7 vols. Leiden: P. van der Eyk \& D. Vygh.

Wertz, C. 1805. Rudimenta of Gronden der Nederduitsche Taal. Leiden: D. du Mortier en zoon \& Deventer: J. H. de Lange \& Groningen: J. Oomkens en zoon.

Westendorp, Nicolaus. 1809. [List of words characteristic of Groningen]. In Laurman 1822: $130-138$.

Wester, Hendrik. 1797 [ $\left.{ }^{2} 1799\right]$. Bevatlyk onderwys in de Nederlandsche spel- en taalkunde, voor de schooljeugd. Groningen: Jan Oomkens. 
Willemyns, Roland. 1993. Integrationism vs. particularism: The undeclared issue at the first 'Dutch Congress' in 1849. In Joshua A. Fishman (ed.), The earliest stage of language planning. The "first congress" phenomenon, 69-83. Berlin: Mouton de Gruyter.

https://doi.org/10.1515/9783110848984.69

Willemyns, Roland. 2003. Het verhaal van het Vlaams. De geschiedenis van de Nederlands in de Zuidelijke Nederlanden. Antwerpen: Standaard \& Utrecht: Spectrum.

Willemyns, Roland. 2013. Dutch. Biography of a language. Oxford: Oxford University Press.

Winkel, L. A. 1863. De grondbeginselen der Nederlandsche spelling. Ontwerp der spelling voor het aanstaande Nederlandsch woordenboek. Leiden: D. Noothoven van Goor.

Winkel, J. te. 1901. Geschiedenis der Nederlandse taal. Culemborg: Blom and Olivierse.

Winkler, Johan. 1874. Algemeen Nederduitsch en Friesch dialecticon. 2 vols. The Hague: Martinus Nijhoff. https://doi.org/10.1007/978-94-011-8823-4

Winschooten, Wigardus à. 1683. Letterkonst. Leiden: S.n.

Wiskerke, Evert M. 1995. De waardering voor de zeventiende-eeuwse literatuur tussen 1780 en 1813. Hilversum: Verloren.

WNT = Woordenboek der Nederlandsche Taal. 1882-1998. 32 vols, http://www.inl.nl/onderzoeka-onderwijs/lexicologie-a-lexicografie/wnt

Wodak, Ruth, Rudolf De Cillia, Martin Reisigl \& Karin Liebhart. 2009. The discursive construction of national identity. Edinburgh: Edinburgh University Press.

Wokler, Robert. 1997. The Enlightenment project and its critics. Poznan studies in the philosophy of the sciences and the humanities 58. 13-30.

Woolard, K. A. 2008. Language and identity choice in Catalonia: The interplay of contrasting ideologies of linguistic authority. In Kirsten Süselbeck, Ulrike Mühlschlegel \& Peter Masson (eds.), Lengua, nación e identidad. La regulación del plurilingüismo en España y América Latina, 303-323. Frankfurt: Vervuert \& Madrid: Iberoamericana.

Woolard, K. A. 2016. Singular and Plural. Ideologies of Linguistic Authority in 21st Century Catalonia. Oxford: Oxford University Press. https://doi.org/10.1093/acprof:0so/9780190258610.001.0001

Wright, Sue. 2012. Language policy, the nation and nationalism. In Bernard Spolsky (ed.), The Cambridge handbook of language policy, 59-78. Cambridge: Cambridge University Press. https://doi.org/10.1017/CBO9780511979026.006

Wright, Sue. 2016. Language policy and language planning: From nationalism to globalisation. 2nd ed. Houndmills etc.: Palgrave Macmillan. https://doi.org/10.1007/978-1-137-57647-7

Ypeij, Annaeus. 1807. Taalkundige aanmerkingen over verouderde en minverstaanbare woorden in de staatenoverzetting des Bijbels. Amsterdam: Wed. G. Warnars.

Ypeij, Annaeus. 1812. Beknopte geschiedenis der Nederlandsche tale. Utrecht: O. J. van Paddenburg. Ypeij, Annaeus. 1832. Beknopte geschiedenis der Nederlandsche taal, tweede deel; bijvoegsels en aanmerkingen behelzende. Groningen: J. Oomkens.

Ypeij, Annaeus \& W. C. Ackersdijck. 1811. Taalkundige aanmerkingen over verouderde en minverstaanbare woorden in de Statenoverzetting des Bijbels, vervolgd door [...]. Utrecht: G. T. van Paddenburg en zoon.

Ziegler, Evelyn. 2007. Putting standard German to the test: Some notes on the linguistic competence of grammar-school students and teachers in the nineteenth century. In Stephan Elspaß, Nils Langer, Joachim Scharloth \& Wim Vandenbussche (eds.) Germanic language histories 'from below' (1700-2000), 309-329. Berlin: De Gruyter. 



\section{Index}

\section{A}

Académie française 160

acceptance 217-218

acquisition planning $2-3,28$,

217

Addison, Joseph 39

Adelung, Johann Christoph

$6,45,131,143,185$

agency 222-223, 274

Albanian 1

Alberdingk Thijm, Joseph Albert

149-150, 152-155, 158

Alewijn, Zacharias Henrik 175

anchoring point $86,88,273$

anonymity $24,79-80,96$, 100-101, 103, 109, 123, 126-127,

$195,272-273$

see also authenticity

see also neutrality

anti-French $77,134,152,179$,

$185,189,203,274$

Arabic 35

archaisation 194-195, 205,

208-209

audience $39,44,46-47,51-54$,

57-58, 63, 71, 92, 106, 113,

$116-117,137,149-150,158,160$,

162,165

authenticisation $\quad 24,75,86$

authenticity 24, 78-80, 86-90,

94, 96-97, 100, 103, 109, 123,

127, 192-193, 195, 197, 205-209,

272-274

see also anonymity

see also non-standard

authenticity

see also standard authenticity

auto-exoticism 194, 201,

206-207, 212

see also exoticism

\section{B}

Bataafsche Maatschappij van Taal- en Dichtkunde 30, 170, 177, 181

Batavian Myth $\quad 81,85$

Becanus, Johannes Goropius 112

Beets, Nicolaas 209, 228-229

Behrns, Johannes Henricus 211-212

van Belle, Jan 54-55, 57-59, 238-239

van den Berg, Ahasverus

134-135, 137-138, 141-142, 199

Berlin Academy 21-22

Bible 54, 87-88, 94, 98, 106, 111, 114-115, 16o, 174 see also Statenbijbel

Bilderdijk, Willem 146, 181

Blair, Hugh $\quad$ 167, 177

de Boer, Jan 202

van Bolhuis, Lambertus 29, 61, $65-69,166,238-239$

boni autores 96 see also good usage

Bormans, Jan Hendrik 150-155

de Bosch, Jeronimo 177

van den Bosch, Pieter $\quad 135-138$

Brabantic 111, 113, 138, 192

Brandt, Geeraert $\quad 83-84,86$

Bredero, Gerbrand Adriaensz 81,113

Brender à Brandis, Gerrit 171

Bussingh, Johannes Wilhelmus 146

\section{C}

van Capelle, Johannes Pieter

$$
\text { 93-94, } 167
$$

Charles V 14, 153

Châtelain, Henri 119

Church Slavonic 35 'civil' grammar 51-54, 59,

$63-64,66,70,171$

see also elitist

see also national grammar

civilisation $25,62,124,233$

classroom 218, 225-226, 230,

$232,236,239,242$

codification 26, 34-36, 39,

$44-47,49,51,53,78,94-95$,

99, 114, 173, 217-218, 225, 234,

$242-243,252,260,274$

commodification of language

103, 274

complaint tradition $\quad 116$

see also grammatical action tradition

de Condillac, Étienne Bonnot

19, 96

convergence $33,39,163,218$, 244

corpus planning $2,28,99$

cultivation of culture 1-2

cultural nationalism $1,3,18-19$,

$75,78-80,169,179,189,275$

see also linguistic nationalism see also nationalism

C.V.E. 21-22

see also van Engelen, Cornelis

D

Danish 48

Dante Alighieri 90

Datheen, Petrus 174

David, Jan Baptist 151, 153-154

de-localisation 44

diaglossia $1,8,33-36,38$, $40-42,44,46,48-51,212-213$, 236,270

dialect $9,27,33-39,41-42$, 44, 48-49, 80, 101, 104-105, 109-110, 112, 114-115, 126-127, $133,142,151,164,180,192-195$, 
197, 201-203, 205, 208-213, 232-237, 251, 270-272, 274

dialectisation 77,91

dialectology $191,193,196,200$, 206-207, 212-213, 270-271

diglossia $34-36,39,41,46$, $48-51,212-213,236,270,274$, 277

generic diglossia 271

diversity $15,24,45,78,114$, 193-194

Donne, John 90

Dulces Ante Omnia Musae 170

Dutchness 85

Dutch studies $9,165-169,176$, 189-191

van Duyse, Prudens 151

\section{$\mathrm{E}$}

education $2-3,5,7-9,13$, 18-20, 24-28, 30-31, 33, 47, $52-53,55,58-59,61-63,66,71$, $76,78,109,118-119,122-128$, $146,166-167,170,173,177,180$, 186, 189-19o, 198, 205, 208, 217-228, 231-232, 235-236, $238-243,270-273,275-277$ educational reform 2, 25, 122, 220, 222, 224-226, 242

Eekma, Petrus 21 van Effen, Justus 201-202 elaboration of function 217 elitist $46,51-54,57,59,63-64$, $66,69-71,85,116-117,119,165$, $171-173,175-176$ see also 'civil' grammar see also national grammar

Elzevier, Kornelis 54-6o, 65-68

van Engelen, Cornelis 21-22, 187

English 1, 24, 33-40, 42-43, $45-49,55-56,58-59,75-76$, $104,116,118,131,165,167$, 192-193, 203, 205, 212, 219, 243,274

Enlightenment $18,25,27-28$, $31,55,63,80,86,89,91$, $122-128,132,164,218-221$ enregisterment 192,196, 205-206, 212 erasure $\quad 23-24,75,106-107,109$, $113-114,128,192,196,198,209$, 212-213, 270, 276

essentialism 2, 81, 86, 109, 190, 272

exclusive $46,52,123,133$, 141-142, 150-151, 154, 156, 158, $160,162-163$

exoticism 193-195, 201, 207, 212 see also auto-exoticism

F

Finnish 2, 48, 193

Flemish $\quad 89,91,104,110-111,115$ 138,192

folklorisation $9,80,165$, 191-192, 194-195, 200, 206, 208-209, 211-212, 274

Formey, Johann 119

Francius, Petrus 54, 84, 116 le Francq van Berkheij, Johannes 193-194

Frenchification $77,86,90,93$, 173, 176, 183-186, 193, 203, 273 see also verfransing

French 2, 17, 27, 33, 35, 47-48, 77-80, 93, 100, 103, 110, 112, 119, $134,152,173,175,179,181,183-$ 185, 188-190, 193, 202-204, 210, 219-220, 228, 236, 243, 273-274

Frisian 93, 113, 115, 192, 197, 207-208, 211, 213

\section{G}

van Geesdalle, Jacques-François 112

German 2, 21, 33-34, 36-38, $40-41,43,45-48,78-80,100$, $103,106,111-112,116,131,151$, $153,155,165,181,183-185,187$, $189,192,210,212,220,231$, 243, 274

Germanic 92, 95,111-113, $116-118,145,187,193,208$, 211-212, 237, 241, 262

Gerth-Van-Wijk 149

Golden Age $\quad 8,15,18,24,75-76$, 79-82, 85-90, 92-100, 103, $127,152,160,168,175-176,179$, 181-184, 189-191, 193, 195-197, 272-273 good usage $82,84,88,92-93$,

115

see also boni autores

grammatical action tradition

116

see also complaint tradition

grammatical writing 227-228, 231-232

see also mechanical writing

Greek 53, 90, 112, 114-115, 142-143, 166, 185-186, 220

Grimm, Jakob 87, 131, 193, 212

Grimm, Wilhelm 131, 193

Grose, Francis 193

Gothic 212, 220

Grotius, Hugo 185

Guelderish 111

\section{$\mathrm{H}$}

de Haes, Frans 54-61

Halbertsma, Joast Hiddes 211 van Halsema, Diderik 199

Hellenismos 85

Herder, Johann Gottfried

19-22, 24-25, 78-79, 96,

194-195, 197

heteroglossia 1

de Heuiter, Pontus 110-111, 114 van Heule, Christiaen 82,113 , 116

hierarchisation $107,109,111-$ $116,118,128,201,233,270$

High German $37-38,46,48$, 111-112, 153, 212, 231

Hilarides, Johannes 197

Hinlópen, Nicolaas 135,138 ,

141-143, 154, 201

historicisation $24,54,75,172$, $174,176,274$

historicity $86-87,194,208-209$

Hoeufft, Jacob Henrik 208

Hoffmann von Fallersleben, August Heinrich 193

Hollandic $89,104,111,115,136$, 146-147, 192, 197, 200-201, 213, 237

Hollandsche Maatschappij der Wetenschappen 62,119

Hollandsche Maatschappij van Fraaije Kunsten en Wetenschappen 170 
homogeneity $1-2,19,23-25,33$, 75-79, 88, 91, 93-94, 97-98, 100-101, 112, 122-128, 178, 189-190, 194, 220, 222, 232, 241, 269-270, 273, 276 see also uniformity

Hooft, Pieter Cornelisz. 54, 81-88, 90-96, 113, 146, $171-172,179,182-183,186,190$, 196-197, 199

van Hoogstraten, David 52, 54, 84-85, 87-88, 90, 95-97, 116-117, 196-197

Hulshoff, Allard 119, 238-241 von Humboldt, Wilhelm 19,187

Huydecoper, Balthazar 52, 54-55, 84-85, 171-172, 175$176,185,197,258$

Huygens, Constantijn 113

I

Icelandic 1-2, 212

iconisation $23-24,75,270$

idioticon $148,150,192-195,198$, 207-208, 210, 212

inclusive $25,27,46,52,62$, $66,69,119,122-125,127-128$, $132-143,145-147,149-159$, 163-164, 198, 200-201, 206, 209, 224, 271

invisibilisation 196,198 intended supralocal variety

43-44, 49

intendiertes Hochdeutsch 43 interdialectal communication 105, 107, 110, 192

van Iperen, Josua 131, 133-136, $138,145-146,151-152,158-159$, 199

Irish 48

Italian 187

\section{J}

de Jager, Arie $151-152,154,158$, $177,208,210$

Japicx, Gysbert 206

le Jeune, Jacob Carel Willem 147

John William Friso of Nassau 16 Johnson, Samuel 39, 131
K

ten Kate, Lambert $\quad 6,45,53-54$, $69,87,137,171-172,174-176$, $185,197,251$

Kleverlandish 111

Kluit, Adriaan 4-5, 7, 95-97, 135, 138, 141, 170, 172, 199-200, 251, 254, 258

Kiliaen, Cornelis 191-192 Kinker, Johannes $\quad 167,170,181$

Kirchdorffer, J.S. 70, 240

Koenen, Hendrik Jacob 154

Koninklijk Instituut 145-147, 151

see also Royal Insitute

Krom, H. J. 120-121, 221

Kunst wordt door Arbeid Verkreegen 30, 61, 169-170 Kunstliefde Spaart geen Vlijt 62,170

L

Lambrecht, Joas 110

language myth $8,24,75-77$, 100, 103, 274

language of immediacy $\quad 42$ language standards 43

Latin $33,35,46,52-53,55-57$, $90,93,112,116,134,140,142$, $173,176,185-186,208,219-$ 220, 228

Latinitas 85

Laurman, Martinus Theodorus 207-208

legitimate language $\quad 50,118$ van Lelyveld, Frans 199 Leupenius, Petrus 113-114 van Lier, Johannes Henricus Petrus 199

linguistic nationalism 2, 19-20, $24,51,75,98,103,128,270,274$ see also cultural nationalism see also nationalism

linguistic relativism 19, 23

Lithuanian 1, 48

Locke, John $\quad$ 19, 24-25, 78-79, 221

Longinus 177

Louis Bonaparte 17

Low German 112, 151, 153, 155, 231
Lowth, Robert 39, 45

Lubbers, Theodorus 199

Lulofs, Barthold Henrik 92-93, 167,208

Luxembourgish 79

M

van Maanen, Cornelis Felix 177 Maaskamp, Evert 194

Maatschappij der Nederlandsche Letterkunde 22-23, 28, 30-31, 61, 91, 134-135, 138-141, 143-145, 147-148, 151, 154, 170, 172, 175-177, 191, 199, 207, 274-275

Maatschappij tot Nut van 't Algemeen 25-27, 29-31, $62-63,66-67,122-124,166$, $171,180,224,226,271$

van Maerlant, Jacob $\quad 89,92-94$, 173

Maria Theresia 2

Martinet, Johannes Florentius 193

Mauricius, Joan Jacob 20

mechanical writing 220,227 see also grammatical writing

Meijer, Gerrit Joan 94, 167

Mestingh, Derk 22

metalanguage $1,46,51,76,99$, $128,165,169,192,195,198$, 235-236, 260, 269, 277

metalinguistic $1,8-9,33-34$, $46-47,50-52,54,60,63-64$, $68-69,71,76-78,84-85$, 92, 94, 99, 106, 109-112, 114, $116-119,122-124,128,133$, 139-140, 165-166, 170-173, 183, 191-192, 196-197, 206, 223, 232, 254-255, 258, 260, 264-267, 270-274, 276-277 metalinguistic space 33,51 Michaelis, Johann David 19-23, 96

Minima crescunt 61,170 moedertaal 20, 23-24, 27, $119-120,125-127,157,182$, 209, 221 see also mother tongue Mone, Franz 210 monoglossia $1,78,271-272$ 
Moonen, Arnold $52-58,60$, 64-68, 84, 87, 95, 97, 116, 251, 254

mother tongue $20,23-24,27$,

31, 51-52, 62, 109, 111-112, 116-122, 125-128, 149, 157, 166, $168,173,178-180,182$, 209, 221, 272-273

see also moedertaal

multilingualism $35,125,236,274$

Murray, Lindley 39,45 myth $8,18,24,73,75-81,85$, 91-92, 94, 97, 100, 103-105, $116,118,127,179,182-183,187$, $189,191,274,276$ see also language myth

\section{$\mathrm{N}$}

Napoleon $\quad 17-18,188$

national character $23,28,78$, 93-94, 153, 181, 187-188 national grammar $30,53,59$, $61,63,66-67,69,86,166$ see also 'civil' grammar see also elitist national identity $47,81,193$ nationalisation $18,118,127-128$, $132,165,172,204,218,223$, 236, 271

nationalism $1-3,8,13,20,75$, $78,179,183,194,217,269-270$, 274-275 see also cultural nationalism see also linguistic nationalism national philologies 168

Nature et Arte 55 neutrality $8,75-76,78-80$, 100-101, 103-111, 113-114, 118, 123-124, 126-128, 145, 191-192, 195, 197, 203, 206, 209, 212, $265,270,272-273$ see also anonymity Nicholson, William 192 non-standard $8-9,23-24,26$, $38,41-42,50,80,107,165,191$, 195, 206, 212, 225, 232, 236, 242, 270-271, 273-274, 277 non-standard authenticity 195 , 205, 207-208 see also authenticity see also standard authenticity norm 33, 35-36, 39, 43-44, $46-48,52,54,58,71,77,85,87$, $96,116,120,137,201,217-219$, 225, 227-232, 235-237, 239, 241-245, 266-267, 277

normative $1,8,33,45,47-48$, $51-54,61,63-68,70-71,77$, $85,87,92-94,96,99,116-117$, $142-143,154,163-165,169,171$, 175-176, 181, 183, 190, 196-198, 230, 250-251, 258, 271-272, 274, 277

Norwegian 193

Nowell, Laurence 192

Nylöe, Jacobus $\quad 54,84,87,116$

O

ontology 87

Opitz, Martin 90

Q

Quintilian 177

\section{P}

van der Palm, Johan Hendrik

7, 30-31, 53, 63, 122, 146, 177, 203, 205, 275

van der Palm, Kornelis 53 , $56,59-63,65-68,119-122$, 238-239

Petrarch, Francesco 90

Philip II 14-15

van der Ploeg, Hidde Wibius 27, 124-127

polite $24,46,50,69,76,116$, $118,142,151-152,154,157-161$, 163-164, 180, 186, 208

politeness 101, 116

political control 25, 28, 51, 220 politicisation $2,3,8,19,25,27$,

$31,75-76,80,128,203,218$

Pope, Alexander 39

Portuguese 1

Prasch, Johann Ludwig 192 prescribe $4,30,35,38,41$, 44, 46, 66, 95-96, 113, 188, 190, 218, 238, 241, 253-254, 258-259, 261, 266, 277

prescription $33,38,44-49$, 51-52, 64, 66-71, 77, 95-97, $117,179,197,238-239,243$,
250-251, 254, 257-258, 266,

277

prescriptivism 2, 39, 45, 47-49,

$116,243,277$

propagation 217

proscribe $4,197-198,256,277$

proscription $47-48,52,198$,

243, 250

Pudor, Christian 116

Puikers, J. 70

R

Rask, Rasmus 87, 212

Ray, John 192

Real Academia Española 2

register $36,39,45-46,48$,

$51-52,57,63,69,91,106$,

$116-117,124-126,174,197,201$, 205-206, 265

reification 122,124

remarqueurs 47,

Richey, Michael 192

Romance 54, 112, 116, 134, 173, 184,187

Romantic $1,20,22,78-80,85$, 100, 103, 160, 194

de Ronsard, Pierre 90

Royal Institute 94, 145 see also Koninklijk Instituut de Ruyter, Michiel 83

S

Schmeller, Andreas 192

Schola Hemsterhusiana 174

school inspection $3,18,28$,

$120,123,222,225-226,242$,

271-272, 276

school inspection reports

225-227, 230, 232, 235-236,

242, 276

school inspector $30,180,186$, 218, 222-26, 229-233, 235-236, 271, 274-277

Schottelius, Justus Georg 45, 112

Schrant, Joannes Mathias $92,167,189$

schrijftaalregeling $3,7,13,244$, 250, 269

Scottish $\quad 48,177$ 
van Santen, Laurens $\quad$ 176-177, 189

selection $99,114,128,131,139$, $172-173,175,217-218,243,270$ Serrure, Constant Philippe 147-148, 209

Séwel, Willem 52, 54-55, $60-61,65-68,117$

Sexagius, Anthonius 110 Siegenbeek, Matthijs 4-7, 9, 13, $23,25,30,53,70-71,78,86$, 92, 94-99, 122, 146, 165-170, $172,176-190,222-223,225$, 228-231, 234, 237-241, 244, 250-254, 256-258, 266-267, 275,277

Sifflé, Alexander François 209, 211, 213

Simons, Adam 167

Slavic 193

SLI $19,75-76,81,86,95-96$, 100, 103-104, 118, 218, 232, 236, 275-276 see also standard language ideology

Smith, Adam 167

Snellaert, Ferdinand Augustijn 148-150, 154

Stalder, Franz Josef 192 sociability $55,61,119,123$ sociolinguistic repertoire

$35,39,41,44,115$ sociolinguistic situation

$8,34-35,42,44,47,49,51,77$, 79, 236, 258, 270, 274 sociolinguistic space 23,26 , $33-34,47,49,51,77,79,106$, 114, 161, 191, 196, 270, 277

Sonius Swaagman, Jan 208 Spanish 2, 15, 24, 79, 90-91, 93, 101,184

splitting of the sociolinguistic continuum $8-9,50,165,191$, 206, 212, 236, 270-271, 274, 276, 277

Sprache der Nähe 42 Stallaert, Karel Frans 154-155 standard 2, 8-9, 23-24, 26-27, $33-39,41-51,69,78-81,88$, 96, 98-99, 103-107, 109, 165 , 190-191, 194-195, 205-206,
209, 211-213, 217-218, 228, 232-237, 243, 251, 266-267, 269-274, 276-277

standard authenticity 195, 205, 208, 273

see also authenticity

see also non-standard authenticity

standardisation $3,33-34,39$, 43-44, 48-50, 77, 98-99, $118,122,149,217-218,225$,

243-244, 249, 275

see also splitting of the sociolinguistic continuum standard language culture 51, 236, 275, 277-278 standard language ideology $1-3,19,26,75-76,79,195,212$, $218,220,225,230,232-236$, 242, 269, 271, 273-275,

277-278

see also SLI

see also splitting of the sociolinguistic continuum

Statenbijbel 87

status planning $\quad 2-3,28$

Stevin, Simon 185

stigmatisation $45,232,234$

Stijl, Klaas $\quad 29,61,65-68$, 238-239

Stoke, Melis $85,89,93-94,173$ street language $\quad 133-134,137$,

$149,151,155,158,161,163,198$, 211, 270

Studium Scientiarum Genitrix 30, 169-170

stylistic level $46,69,178$

supralocalisation $33-34,37-38$, 41-44, 48-49, 51, 53, 106-107, 109-110, 113-115, 118, 125-127, 190, 192, 201-206, 213, 218,

221, 238, 270-272

supraregionalisation $27,42,46$, 80, 98, 192, 197

Swaving, Henri Isaak 209 Swift, Jonathan 39,116 systemic coherence 87,89
$\mathrm{T}$

target audience $46-47,51,53$, $57,71,116,137,149,158,160$, 165

teachers' societies 224-225

teacher-training colleges 28 , 221, 224-225

teacher-training programmes 123,224

Tollius, Herman $\quad 134,138,166$, 170

Tydeman, Hendrik Willem 177

Tydeman, Meinard 7,20, 166, 170, 173, 177

U

uniformity $23-24,37,39$, $43-44,46-47,50,77-78,91$, $93,95,98,110,112,114,120$, $136,149,172-173,183,196,228$, 230, 235, 248, 273 see also homogeneity

usage guide 1,46

usus 96

Utenhove, Jan 111

V

van Varenbraken, Christiaen 110 van Varik, Gerrit 30, 61, 63, 65-69, 238-239

de Vaugelas, Claude Favre 2, 47 van Velthem, Lodewijk 199 verfransing 173,184 see also Frenchification verticalisation 107,118 Verwer, Adriaen $\quad 53-54,65-68$, $85,87-88,90,115,117,166$, 171-172, 175-176, 197

Vico, Giambattista 19

Vollenhove, Joannes $\quad 83-84,86$ van den Vondel, Joost 52,54 ,

81-88, 90-96, 98, 167, 171-172, 179, 181-183, 186, 190, 196-197

Vondelianism $52,54,61,84-87$, 90, 92, 95-97, 116, 183, 196-197 van Voorst, Dirk Cornelis 120-121

van der Voort, Michiel 152 de Vries, Jeronimo 86 de Vries, Matthias 5, 98, 131, 154-163 
W

Wassenbergh, Everwinus 166, 207-208

te Water, Jona Willem 199

Weiland, Pieter $5-7,13,25$, 30, 53, 64-71, 78, 92, 96-97, 122, 140, 143-146, 165, 167,

169, 180, 199, 209, 222, 225,

229-231, 234, 237, 240, 244, 250, 258, 260, 264-267

Westendorp, Nicolaus 207

Wester, Hendrik $\quad 61,65-68$, 226, 238-241
Wij Streeven naar de

Volmaaktheid 30,170

Wilhelmina of Prussia 17

Willems, Jan Frans 177,210

William I 16, 18, 92, 167

William II 16

William III 16

William IV 16

William V 16-17

te Winkel, Lamert Allard 5

Winschooten, Wigardus à

114-115

writing convention $\quad 38,40-41$,

43
Y

Ypeij, Annaeus 87-94, 99-101, 207-208

Z

Zeeuws Genootschap der

Wetenschappen 62,120 
The decades around 1800 constitute the seminal period of European nationalism. The linguistic corollary of this was the rise of standard language ideology, from Finland to Spain, and from Iceland to the Habsburg Empire. Amidst these international events, the case of Dutch in the Netherlands offers a unique example. After the rise of the ideology from the 1750 s onwards, the new discourse of one language-one nation was swiftly transformed into concrete top-down policies aimed at the dissemination of the newly devised standard language across the entire population of the newly established Dutch nation-state. Thus, the Dutch case offers an exciting perspective on the concomitant rise of cultural nationalism, national language planning and standard language ideology.

This study offers a comprehensive yet detailed analysis of these phenomena by focussing on the ideology underpinning the new language policy, the institutionalisation of this ideology in metalinguistic discourse, the implementation of the policy in education, and the effects of the policy on actual language use.

ISBN 9789027202406

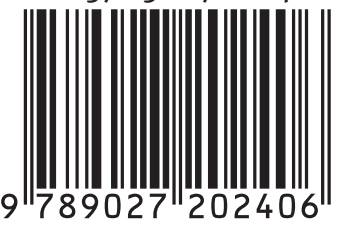

\section{John Benjamins Publishing Company}

